\title{
EFEITOS DO CÁDMIO SOBRE A FERMENTAÇÃO ALCÓOLICA E O USO DA VINHAÇA PARA ATENUAR A SUA AÇÃO TÓXICA
}

SAMUEL MARIANO GISLON DA SILVA

Engenheiro Agrônomo

\section{Orientador: Prof. Dr. LuIz CARLOS BASSO}

Tese apresentada à Escola Superior de Agricultura "Luiz de Queiroz", Universidade de São Paulo, para a obtenção do título de Doutor em Agronomia, Área de Concentração: Microbiologia Agrícola.

PIRACICABA

Estado de São Paulo - Brasil

Setembro - 2001 
Dados Internacionais de Catalogaçāo na Publicaçāo (CIP) DIVISĀO DE BIBLIOTECA E DOCUMENTAÇĀO - Campus "Luiz de Queiroz"/USP

Silva, Samuel Mariano Gislon da

Efeitos do cádmio sobre a fermentação alcóolica e o uso da vinhaça para atenuar a sua ação tóxica / Samuel Mariano Gislon da Silva. - - Piracicaba, 2001.

134 p. : il.

Tese (doutorado) - Escola Superior de Agricultura Luiz de Queiroz, 2001.

Bibliografia.

1. Cádmio 2. Fermentação alcoólica 3. Levedura 4. Metal pesado 5. Reciclagem 6. Toxicidade 7. Vinhaça I. Título

CDD 663.13

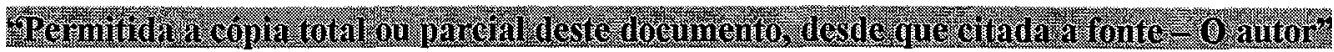


Samuel Mariano Gision da Silva. EFEITOS DO CÁDMIO SOBRE A FERMENTAÇÃO ALCOÓLICA E O USO DA VINHAÇA PARA ATENUAR A SUA AÇÃO TÓXICA

\begin{tabular}{|c|c|c|c|c|}
\hline p. & item & linha & onde se lê & leia-se \\
\hline 8 & 2.3 & terceira & ...mecanismo de toxidade do cádmio. & ...mecanismo de toxicidade do cádmio. \\
\hline 8 & 2.3 & oitava & É principalmente encontrados... & É principalmente encontrado... \\
\hline 9 & 2.3 & segunda & ...sinais de toxidade aparecem... & ...sinais de toxicidade aparecem... \\
\hline 9 & 2.3 & décima oitava & ...causou a descaucificação... & ...causou a descalcificação... \\
\hline 15 & 2.5 & terceira & ...Smith and Wood... & ...Smith \& Wood... \\
\hline 16 & 2.5 & terceira & ...ânion hidrogênio... & ...cátion hidrogênio... \\
\hline 21 & 3.1.1.1 & sétima & ...água deionizada e secagem... & ...água desionizada e secagem... \\
\hline 24 & 3.1.1.8 & terceira & ...Anton Paasr... & ...Anton Paar... \\
\hline 25 & 3.3.1.1 & décima primeira & 3.3.1.1 Obtenção da vinhaça & 3.3.1.3 Obtenção da vinhaça \\
\hline 35 & 3.4.1.7 & quarta & $\begin{array}{l}\text {...esterilizada (ou vinhaça, de acordo } \\
\text { com o tratamento), submetida... }\end{array}$ & ...esterilizada e submetida... \\
\hline 39 & 3.5.1.7 & sétima & $\begin{array}{l}\text {...esterilizada (ou vinhaça, de acordo } \\
\text { com o tratamento), submetida... }\end{array}$ & ...esterilizada e submetida... \\
\hline 44 & 4.1 & vigésima sétima & $\begin{array}{l}\text {...mensurada no final e no início dos } \\
\text { ensaios... }\end{array}$ & ...mensurado no final dos ensaios... \\
\hline 44 & & & ...que a toxidade para... & ...que a toxicidade para... \\
\hline 46 & 4.1 & décima nona & (Tabela 06) & ...(Tabela 6$)$ \\
\hline 47 & 4.1 & segunda & ...Smith and Wood... & ...Smith \& Wood... \\
\hline 81 & 4.5 & segunda & $\begin{array}{l}\text {...ao tratamento com } 0,05 \mathrm{mmol} \mathrm{L}^{-1} \mathrm{de} \\
\text { cádmio... }\end{array}$ & $\begin{array}{l}\text {...ao tratamento com } 0,025 \mathrm{mmol}^{-1} \mathrm{de} \\
\text { cádmio... }\end{array}$ \\
\hline 125 & $\begin{array}{l}\text { referências } \\
\text { bibliográficas }\end{array}$ & nona & ...in Saccharomyces cerevisiae... & ....in Saccharomyces cerevisiae ... \\
\hline 127 & $\begin{array}{c}\text { referências } \\
\text { bibliográficas }\end{array}$ & sexta & $\begin{array}{l}\text {...from Saccharomyces cerevisiae } \\
\text { by ... }\end{array}$ & $\begin{array}{l}\text {...form Saccharomyces cerevisiae } \\
\text { by... }\end{array}$ \\
\hline 132 & $\begin{array}{l}\text { referências } \\
\text { bibliográficas }\end{array}$ & décima quinta & ... of Saccharomyces cerevisiae... & ...of Saccharomyces cerevisiae... \\
\hline
\end{tabular}


Ao bom Deus,

Agradeço..

Para meus pais, Brando e Irene,

\title{
Ofereço.
}

Para minha esposa Fabiana,

\author{
Dedico.
}




\section{AGRADECIMENTOS}

A Universidade de São Paulo, pela minha formação;

Ao Professor Dr. Luiz Carlos Basso, pela oportunidade, amizade, confiança e orientação;

Ao Professor Titular Luiz Gonzaga do Prado Filho, pela amizade e colaboração;

Ao Curso de Pós Graduação em Microbiologia Agrícola, na pessoa do seu Coordenador Professor Titular Flávio Tavares;

A Fundação de Amparo à Pesquisa do Estado de São Paulo (FAPESP) pela bolsa de estudos e financiamento do projeto de pesquisa, que permitiram a realização deste trabalho;

Aos professores da ESALQ/USP, pelos conhecimentos transmitidos; 
Ao Núcleo de Apoio à Pesquisa / Microscopia Eletrônica Aplicada à Pesquisa Agropecuária (NAP/MEPA/USP) na pessoa da Técnica Maria das Graças Ongarelli do Departamento de Ciências Biológicas (ESALQ/USP);

A Bibliotecária Chefe da Seção de Referência da ESALQ/USP Eliana Maria Garcia, pelo atendimento e presteza na revisão da parte editorial e normalização das referências bibliográficas;

Aos Técnicos de Laboratório Luiz Lucatti e Ademir de Campos e as Estagiárias Mariana Dallaqua, Juliana Travaiogli e Camila Cartes pela amizade e auxílio prestado em todos os momentos da confeç̧ão deste trabalho;

Aos colegas Rudimar Antonio Cherubin, Fábio Patrick de Freitas, Denise Maria Gândara Alves e Cilene Paulillo pelo companherismo e amizade;

A todos que direta ou indiretamente contribuíram para a realização deste trabalho. 


\section{SUMÁRIO}

Página

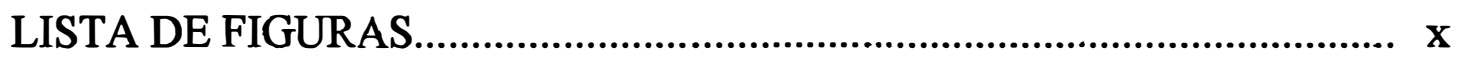

LISTA DE TABELAS..................................................................

LISTA DE ANEXOS.................................................................... xvi

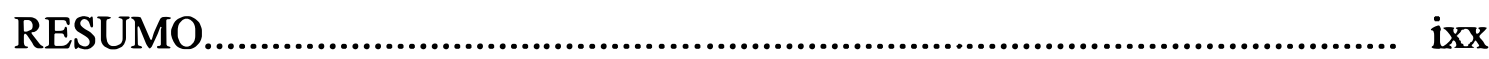

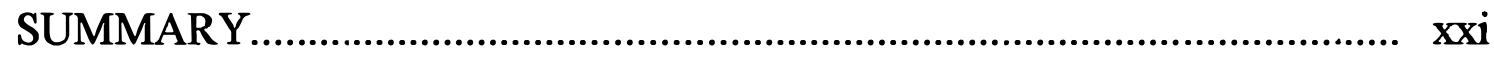

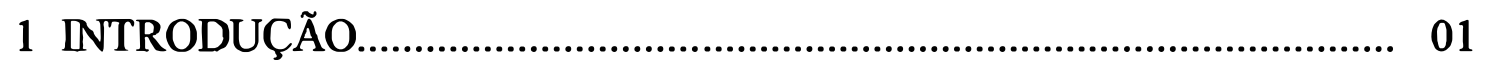

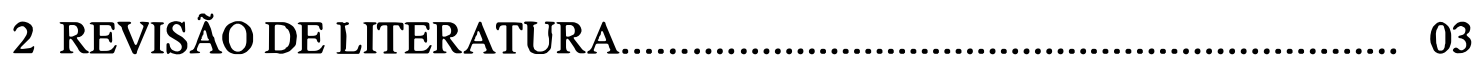

2.1 Os metais pesados no meio ambiente................................................... 03

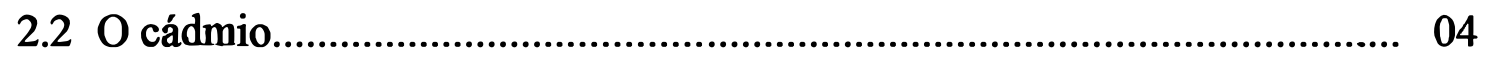

2.3 Toxicidade do cádmio ...................................................................... 06

2.4 Os metais pesados em solos agrícolas................................................ 10

2.5 Os metais pesados e a fermentação alcoólica......................................... 12

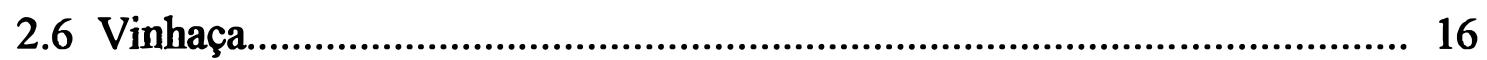

2.7 Influência de outros cátions e de compostos orgânicos na atenuação da toxicidade do cádmio........................................................ 18

3 MATERIAL E MÉTODOS.............................................................. 21

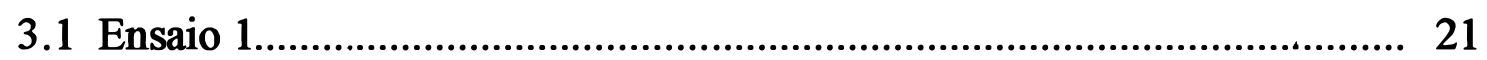

3.1.1 Procedimento experimental..................................................... 21

3.1.1.1 Preparo da vidraria..................................................................... 21 
3.1.1.2 Preparo das soluções.............................................................. 21

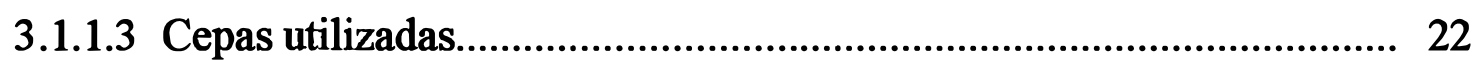

3.1.1.4 Pré-crescimento das leveduras.................................................... 22

3.1.1.5 Ensaio de crescimento.................................................................. 22

3.1.1.6 Análises de crescimento............................................................. 23

3.1.1.7 Taxa de viabilidade, taxa de brotamento e contaminação

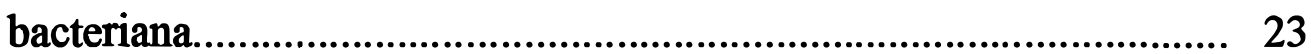



3.1.1.9 Análise de trealose .................................................................. 24

3.1.1.10 Análise estatística..................................................................... 24

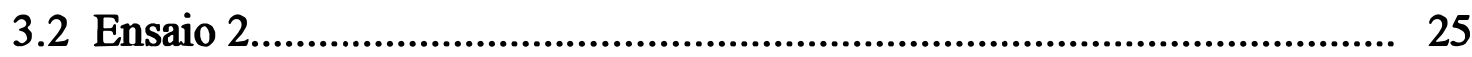

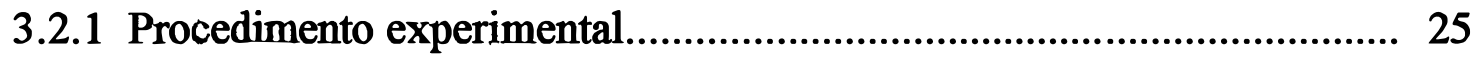

3.2.1.1 Preparo da vidraria......................................................................... 25

3.2.1.2 Preparo das soluções................................................................... 25

3.2.1.3 Obtenção da vinhaça..................................................................... 25

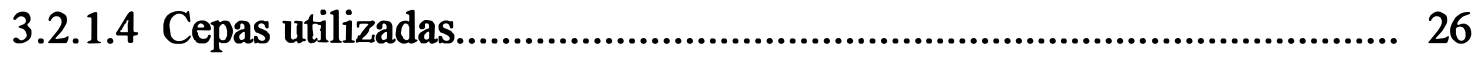

3.2.1.5 Pré-crescimento das leveduras...................................................... 26

3.2.1.6 Ensaio de crescimento................................................................. 26

3.2.1.7 Análises do crescimento.......................................................... 27

3.2.1.8 Taxa de viabilidade, taxa de brotamento e contaminação

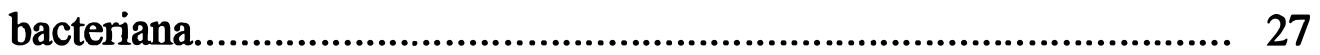

3.2.1.9 Análise de etanol....................................................................... 27

3.2.1.10 Análise de trealose.................................................................. 27

3.2.1.11 Análise estatística.................................................................. 28

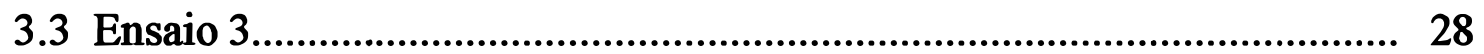

3.3.1 Procedimento experimental.......................................................... 28

3.3.1.1 Preparo da vidraria.................................................................. 28 
3.3.1.2 Preparo das soluções................................................................. 28

3.3.1.3 Cepa utilizada........................................................................ 29

3.3.1.4 Preparo do caldo-de-cana............................................................. 29

3.3.1.5 Pré-crescimento da levedura....................................................... 29

3.3.1.6 Ensaio de fermentação..................................................................... 29

3.3.1.7 Taxa de viabilidade, taxa de brotamento e contaminação

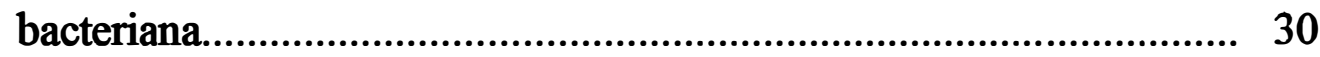

3.3.1.8 Análise do etanol...................................................................... 30

3.3.1.9 Análise do glicerol e de açúcares residuais (sacarose, frutose e glicose) no vinho................................................................... 30

3.3.1.10 Densidade dos vinhos delevurados............................................. 31

3.3.1.11 pH dos vinhos delevurados................................................... 31

3.3.1.12 Análise de glicogênio................................................................. 31

3.3.1.13 Análise de trealose............................................................... 32

3.3.1.14 Análise de nitrogênio.............................................................. 32

3.3.1.15 Cálculo do rendimento fermentativo......................................... 32

3.3.1.16 Análise estatística....................................................................... 33

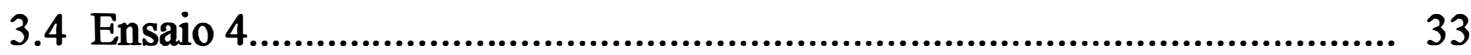

3.4.1 Procedimento experimental............................................................ 33

3.4.1.1 Preparo da vidraria................................................................... 33

3.4.1.2 Preparo das soluções................................................................... 34

3.4.1.3 Obtenção da vinhaça................................................................. 34

3.4.1.4. Preparo do caldo-de-cana............................................................... 34

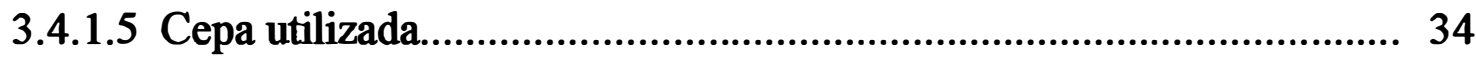

3.4.1.6 Pré-crescimento da levedura....................................................... 34

3.4.1.7 Ensaio de fermentação................................................................. 35 
3.4.1.8 Taxa de viabilidade, taxa de brotamento e contaminação bacteriana.

3.3.1.9 Análise do etanol. 36

3.4.1.10 Análise do glicerol e de açúcares residuais (sacarose, frutose e glicose) no vinho. 36

3.3.1.11 Densidade dos vinhos delevurados........................................... 36

3.4.1.12 ph dos vinhos delevurados......................................................... 36

3.4.1.13 Análise de glicogênio................................................................ 36

3.4.1.14 Análise de trealose................................................................ 37

3.4.1.15 Análise de nitrogênio............................................................. 37

3.4.1.16 Cálculo do rendimento fermentativo............................................ 37

3.4.1.17 Análise estatística................................................................ 37

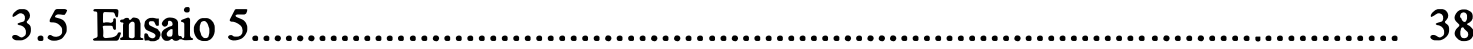

3.5.1 Procedimento experimental.......................................................... 38

3.5.1.1 Preparo da vidraria.................................................................. 38

3.5.1.2 Preparo das soluções.............................................................. 38

3.5.1.3 Obtenção da vinhaça........................................................................ 38

3.5.1.4 Preparo do caldo-de-cana............................................................ 38

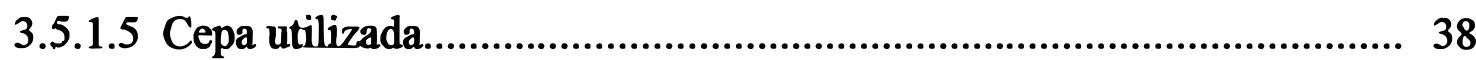

3.5.1.6 Pré-crescimento da levedura........................................................ 39

3.5.1.7 Ensaio de fermentação................................................................ 39

3.5.1.8 Taxa de viabilidade, taxa de brotamento e contaminação

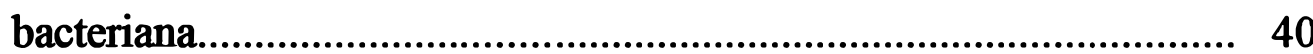

3.5.1.9 Microscopia eletrônica de varredura ............................................ 40

3.5.1.10 Determinação do acúmulo de cádmio.......................................... 40

3.5.1.11 Análise estatística........................................................................ 41

4 RESULTADOS E DISCUSSÃO ….................................................... 42 


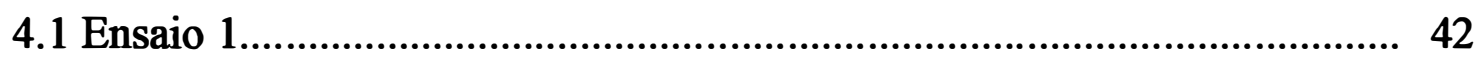



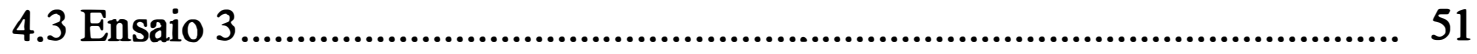

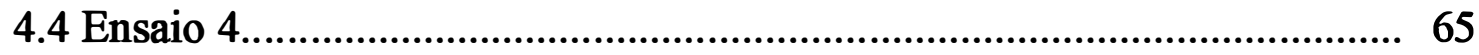

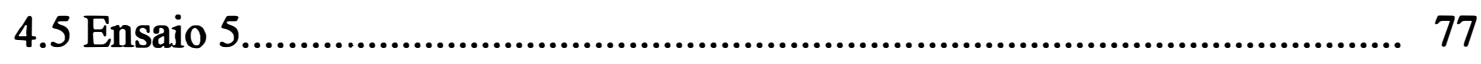

5 CONCLUSÕES.............................................................................. 86

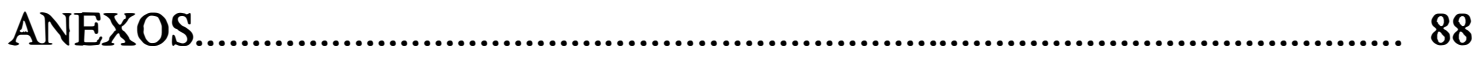

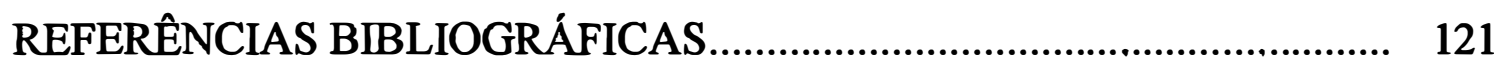




\section{LISTA DE FIGURAS}

Página

1 Alguns dos mecanismos que envolvem a absorção de cádmio por leveduras

2 Crescimento da levedura IZ-1904 em meios com diferentes concentrações de cádmio.

3 Crescimento da levedura PE-2 1904 em meios com diferentes concentrações cádmio

4 Crescimento da levedura PE-2 em presença de vinhaça no meio $(0,15$ e $30 \%)$

5 Crescimento da levedura PE-2 em meio com cádmio $\left(0,1 \mathrm{mmol} \mathrm{L}^{-1}\right)$ de cádmio e diferentes concentrações de vinhaça $(0,15$ e $30 \%)$.

6 Crescimento da levedura PE-2 em meio com cádmio $\left(0,5 \mathrm{mmol} \mathrm{L}{ }^{-1}\right)$ de cádmio e diferentes concentrações de vinhaça $(0,15$ e $30 \%)$.

7 Efeito de cinco concentrações de cádmio sobre o rendimento fermentativo (\%), no transcorrer de 6 reciclos fermentativos.

8 Efeito de cinco concentrações de cádmio sobre o crescimento do fermento $(\mathrm{g})$, no transcorrer de 6 reciclos fermentativos.

9 Efeito de cinco concentrações de cádmio sobre a formação de etanol (\% v/v), no transcorrer de 6 reciclos fermentativos 
10 Efeito de cinco concentrações de cádmio sobre a formação de glicerol (g/ 100 g ART), no transcorrer de 6 reciclos fermentativos.

11 Efeito de cinco concentrações de cádmio sobre a glicose residual no vinho $\left(\mathrm{g} 100 \mathrm{ml}^{-1}\right)$, no transcorrer de 6 reciclos fermentativos. 54

12 Efeito de cinco concentrações de cádmio sobre a frutose residual no vinho $\left(\mathrm{g} 100 \mathrm{ml}^{-1}\right)$, no transcorrer de 6 reciclos fermentativos. 54

13 Efeito de cinco concentrações de cádmio sobre a viabilidade do fermento (\%), no transcorrer de 6 reciclos fermentativos.

14 Efeito de cinco concentrações de cádmio sobre o brotamento do fermento, no transcorrer de 6 reciclos fermentativos.

15 Efeito de cinco concentrações de cádmio sobre a glicose residual no vinho $\left(\mathrm{g} 100 \mathrm{~mL}^{-1}\right)$, no transcorrer de 6 reciclos fermentativos.

16 Efeito de cinco concentrações de cádmio sobre o $\mathrm{pH}$ do vinho, no transcorrer de 6 reciclos fermentativos.

17 Efeito de cinco concentrações de cádmio sobre os teores de trealose ( $\left(100 \mathrm{~g}^{-1}\right.$ ) nos fermentos do início do experimento e do final do último ciclo fermentativo.

18 Efeito de cinco concentrações de cádmio sobre os teores de glicogênio $\left(\mathrm{g} 100 \mathrm{~g}^{-1}\right)$ nos fermentos do início do experimento e do final do último ciclo fermentativo

19 Efeito de cinco concentrações de cádmio sobre os teores de nitrogênio nos fermentos do início do experimento e do final do último ciclo fermentativo.

20 Produção de $\mathrm{CO}_{2}$ durante o primeiro ciclo.

21 Produção de $\mathrm{CO}_{2}$ durante o segundo ciclo.

22 Produção de $\mathrm{CO}_{2}$ durante o terceiro ciclo 60

23 Produção de $\mathrm{CO}_{2}$ durante o quarto ciclo. 
24 Produção de $\mathrm{CO}_{2}$ durante o quinto ciclo.

25 Produção de $\mathrm{CO}_{2}$ durante o sexto ciclo.

26 Efeito de duas concentrações de cádmio combinadas com duas concentrações de vinhaça sobre o rendimento fermentativo (\%), no transcorrer de 6 reciclos fermentativos.

27 Efeito de duas concentrações de cádmio combinadas com duas concentrações de vinhaça sobre o crescimento do fermento (g), no transcorrer de 6 reciclos fermentativos.

28 Efeito de duas concentrações de cádmio combinadas com duas concentrações de vinhaça sobre a formação de etanol (\% v/v), no transcorrer de 6 reciclos fermentativos.

29 Efeito de duas concentrações de cádmio combinadas com duas concentrações de vinhaça sobre a formação de glicerol (g / 100 g ART), no transcorrer de 6 reciclos fermentativos.

30 Efeito de duas concentrações de cádmio combinadas com duas concentrações de vinhaça sobre a glicose residual no vinho $\left(\mathrm{g} 100 \mathrm{ml}^{-1}\right)$, no transcorrer de 6 reciclos fermentativos. 68

31 Efeito de duas concentrações de cádmio combinadas com duas concentrações de vinhaça sobre a frutose residual no vinho (g $100 \mathrm{~mL}^{-1}$ ), no transcorrer de 6 reciclos fermentativos. 68

32 Efeito de duas concentrações de cádmio combinadas com duas concentrações de vinhaça sobre a viabilidade do fermento (\%), no transcorrer de 6 reciclos fermentativos.

33 Efeito de duas concentrações de cádmio combinadas com duas concentrações de vinhaça sobre o brotamento do fermento, no transcorrer de 6 reciclos fermentativos.

34 Efeito de duas concentrações de cádmio combinadas com duas concentrações de vinhaça sobre a glicose residual no vinho $\left(\mathrm{g} 100 \mathrm{~mL}^{-1}\right)$, no transcorrer de 6 reciclos fermentativos. 
35 Efeito de duas concentrações de cádmio combinadas com duas concentrações de vinhaça sobre o pH do vinho, no transcorrer de 6 reciclos fermentativos.

36 Efeito de duas concentrações de cádmio combinadas com duas

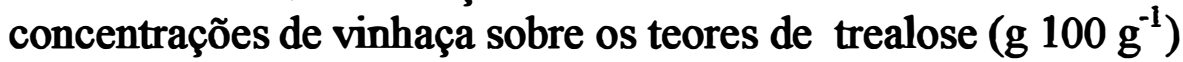
nos fermentos do início do experimento e do final do último ciclo fermentativo.

37 Efeito de duas concentrações de cádmio combinadas com duas concentrações de vinhaça sobre os teores de glicogênio $\left(\mathrm{g} 100 \mathrm{~g}^{-1}\right)$ nos fermentos do início do experimento e do final do último ciclo fermentativo.

38 Efeito de duas concentrações de cádmio combinadas com duas concentrações de vinhaça sobre os teores de nitrogênio (\%) nos fermentos do início do experimento e do final do último ciclo fermentativo.

39 Produção de $\mathrm{CO}_{2}$ durante o primeiro ciclo. 73

40 Produção de $\mathrm{CO}_{2}$ durante o segundo ciclo. 73

41 Produção de $\mathrm{CO}_{2}$ durante o terceiro ciclo. 74

42 Produção de $\mathrm{CO}_{2}$ durante o quarto ciclo. 74

43 Produção de $\mathrm{CO}_{2}$ durante o quinto ciclo. 75

44 Produção de $\mathrm{CO}_{2}$ durante o sexto ciclo. 75

45 Efeito de duas concentrações de cádmio e duas concentrações de vinhaça sobre a taxa de viabilidade do fermento, no transcorrer de 6 reciclos fermentativos

46 Efeito de duas concentrações de cádmio e duas concentrações de vinhaça sobre a taxa de brotamento do fermento, no transcorrer de 6 reciclos fermentativos. 
47 Efeito de duas concentrações de cádmio e duas concentrações de vinhaça sobre a bioacumulação de cádmio pela levedura no transcorrer de 6 reciclos fermentativos.

48 Efeito de duas concentrações de cádmio e duas concentrações

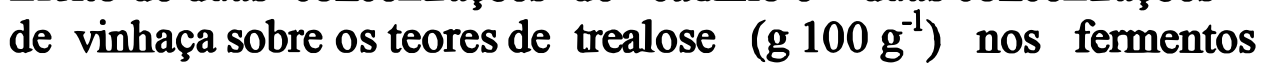
do início do experimento e do final do último ciclo fermentativo

49 Efeito de duas concentrações de cádmio e duas concentrações de vinhaça sobre os teores de glicogênio $\left(\mathrm{g} 100 \mathrm{~g}^{-1}\right)$ nos fermentos do início do experimento e do final do último ciclo fermentativo

50 Levedura submetida a ao tratamento com $0,0 \mathrm{mmol} \mathrm{L}{ }^{-1}$ de cádmio $+25 \%$ de vinhaça

51 Leveduras submetidas ao tratamento com $0,05 \mathrm{mmol} \mathrm{L}^{-1}$ de cádmio. $+25 \%$ de vinhaça.

52 Leveduras submetidas ao tratamento com $0,025 \mathrm{mmol} \mathrm{L}^{-1}$ de cádmio. $+0 \%$ de vinhaça.

53 Leveduras submetidas ao tratamento com $0,025 \mathrm{mmol} \mathrm{L}^{-1}$ de cádmio. $+0 \%$ de vinhaça.

54 Leveduras submetidas ao tratamento com $0,025 \mathrm{mmol} \mathrm{L}^{-1}$ de cádmio. $+0 \%$ de vinhaça.

55 Leveduras submetidas ao tratamento com $0,025 \mathrm{mmol} \mathrm{L}^{-1}$ de cádmio. $+0 \%$ de vinhaça

56 Leveduras submetidas ao tratamento com $0,025 \mathrm{mmol} \mathrm{L}^{-1}$ de cádmio. $+0 \%$ de vinhaça.

57 Leveduras submetidas ao tratamento com $0,025 \mathrm{mmol} \mathrm{L}^{-1}$ de cádmio. $+0 \%$ de vinhaça 


\section{LISTA DE TABELAS}

Página

1 Propriedades físicas de alguns compostos de cádmio.............................. 07

2 Previsão da produção diária de lodo de esgoto nas principais estações de tratamento de esgoto da SABESP (ano 2005)

3 Previsão de produção de Biossólidos nas ETEs da SABESP

4 Composição média de três tipos de vinhaça, provenientes de diferentes tipos de meio de fermentação.

5 Taxa de viabilidade (\%) e taxa de brotamento (\%) no final dos ensaios (18 horas)

6 Trealose ( $\left(00 \mathrm{~g}^{-1}\right)$, mensurada no início e no final dos ensaios (18 horas) para cada levedura.

7 Álcool (\% v/v), mensurada no início e no final dos ensaios (18 horas) para cada levedura.

8 Taxa deviabilidade (\%) e taxa de brotamento ao final dos ensaios (18 horas).

9 Trealose (g $\left.100 \mathrm{~g}^{-1}\right)$, mensurada no início e no final dos ensaios (18 horas).

10 Álcool (\% v/v) no vinho no final dos ensaios (18 horas). 50 


\section{LISTA DE ANEXOS}

Página

1 Reta padrão utilizada para determinar a concentração levedura IZ-1904...... 89

2 Reta padrão utilizada para determinar a concentração levedura PE-2 .......... 90

3 Crescimento (g $100 \mathrm{~mL}^{-1}$ de meio) da levedura PE-2 frente diferentes concentrações de cádmio - Crescimento $\left(\mathrm{g} 100 \mathrm{~mL}^{-1}\right.$ de meio) da levedura IZ-1904 frente diferentes concentrações de cádmio

4 Análise estatística do ensaio 1 ................................................................ 92

5 Análise da composição mineral da vinhaça e do caldo de cana.................. 93

6 Reta padrão utilizada para determinar a concentração da levedura PE-2..... 94

7 Crescimento da levedura PE-2 (em g $100 \mathrm{~mL}^{-1}$ de meio) submetida a diferentes tratamentos

8 Análise estatística do ensaio 2 ............................................................. 96

9 Efeito de 5 doses de cádmio sobre o rendimento fermentativo (\%), crescimento do fermento (g) e formação de etanol (\% v / v), no transcorrer de 6 ciclos fermentativos

10 Efeito de 5 doses de cádmio sobre a formação de glicerol (g / $100 \mathrm{~g}$ ART) e glicose $\left(\mathrm{g} 100 \mathrm{~mL}^{-1}\right)$ e frutose $\left(\mathrm{g} 100 \mathrm{~mL}^{-1}\right)$ residuais no vinho, no transcorrer de 6 ciclos fermentativos. 98 
11 Efeito de 5 doses de cádmio sobre a taxa de viabilidade (\%), taxa de brotamento (\%) e contaminação bacteriana, no transcorrer de 6 ciclos fermentativos.

12 Efeito de 5 doses de cádmio sobre o teor de sacarose residual no vinho $\left(\mathrm{g} 100 \mathrm{~mL}^{-1}\right)$ e $\mathrm{pH}$ do vinho no transcorrer de 6 ciclos fermentativos.

13 Efeito de 5 doses de cádmio sobre os teores de trealose (\% MS), glicogênio (\% MS) e nitrogênio (\% MS) iniciais e finais.

14 Efeito de 5 doses de cádmio sobre a velocidade da fermentação, estimada em produção de $\mathrm{CO}_{2}$ (em g) a cada hora, no transcorrer de 6 ciclos fermentativos.

15 Análise estatística do ensaio 3 103

16 Efeito de 2 doses de cádmio e duas doses de vinhaça sobre o rendimento fermentativo (\%), crescimento do fermento (g) e formação de etanol (\% v/v), no transcorrer de 6 ciclos fermentativos.

17 Efeito de 2 doses de cádmio e 2 doses de vinhaça sobre a formação de glicerol (g / $100 \mathrm{~g}$ ART) e glicose $\left(\mathrm{g} 100 \mathrm{~mL}^{-1}\right) \mathrm{e}$

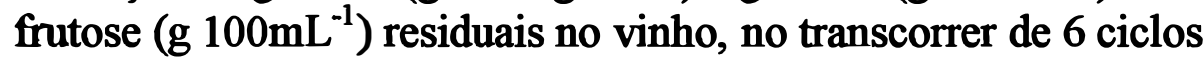
fermentativos

18 Efeito de 2 doses de cádmio e 2 doses de vinhaça sobre a taxa de viabilidade (\%), taxa de brotamento (\%) e contaminação bacteriana, no transcorrer de 6 ciclos fermentativos.

19 Efeito de 5 doses de cádmio sobre o teor de sacarose residual no vinho $\left(\mathrm{g} 100 \mathrm{~mL}^{-1}\right)$ e $\mathrm{pH}$ do vinho no transcorrer de 6 ciclos fermentativos. 110

20 Efeito de 2 doses de cádmio e 2 doses de vinhaça sobre os teores de trealose (\% MS), glicogênio (\% MS) e proteína (\% MS) imciais e finais. 
21 Efeito de 2 doses de cádmio e 2 doses de vinhaça sobre a velocidade da fermentação, estimada em produção de $\mathrm{CO}_{2}$ (em g) a cada hora, no transcorrer de 6 ciclos fermentativos.

22 Análise estatística ensaio 4

23 Efeito de três doses de cádmio e duas doses de vinhaça sobre a taxa de viabilidade (\%) e taxa de brotamento (\%) no transcorrer de 6 ciclos fermentativos

24 Efeito de três doses de cádmio e duas doses de vinhaça sobre os teores de trealose $\left(\mathrm{g} 100 \mathrm{~g}^{-1}\right)$ e glicogênio $\left(\mathrm{g} 100 \mathrm{~g}^{-1}\right)$ ao final do sexto ciclo e acúmulo de cádmio ( ) no transcorrer de 6 ciclos fermentativos.

25 Análise estatística do ensaio 5 


\title{
EFEITOS DO CÁDMIO SOBRE A FERMENTAÇÃO ALCÓOLICA E O USO DA VINHAÇA PARA ATENUAR A SUA AÇÃO TÓXICA
}

\author{
Autor: SAMUEL MARIANO DA SILVA \\ Orientador:Prof Dr. LUIZ CARLOS BASSO
}

\section{RESUMO}

O presente trabalho teve por finalidade estudar os efeitos do cádmio sobre alguns parâmetros de uma fermentação alcoólica com reutilização da levedura, ou seja, submetida a reciclos fermentativos, bem como avaliar a possibilidade de utilizar a vinhaça como fornecedora de agentes ligantes do metal visando minimizar os efeitos deletérios do mesmo. Os parâmetros analisados foram o rendimento em álcool, a formação de glicerol, o crescimento da levedura no transcorrer dos reciclos, os teores de sacarose, glicose e frutose residuais nos vinhos, a velocidade de fermentação, os teores dos carboidratos de reserva (glicogênio e trealose), a viabilidade celular, o acúmulo de cádmio, danos à integridade da parede celular, a taxa de brotamento da levedura e a contaminação bacteriana. Os aumentos nos níveis de cádmio nos mostos provocaram uma redução no acúmulo de trealose bem como no crescimento celular e taxa de viabilidade. Na dose estudada 
$\left(0,025 \mathrm{mmol} \mathrm{L}{ }^{-1}\right)$ ocorreu acúmulo de cádmio durante os seis reciclos. A vinhaça provocou um discreto efeito tóxico, traduzido em redução da viabilidade e do teor de trealose, porém protegeu as células de levedura quando os meios de fermentação tinham cádmio. Os teores de trealose mostraram uma ótima correlação com a taxa de viabilidade e crescimento da levedura, sendo que este parâmetro refletiu o estado fisiológico de estresse ao qual a levedura foi submetida. 


\title{
EFFECTS OF CADMIUM TOWARDS YEAST FERMENTATION, AND THE USE OF VINASSE TO ATENUATE THE TOXIC EFFECTS
}

\author{
Author: SAMUEL MARIANO DA SILVA \\ Adviser: Prof Dr. LUIZ CARLOS BASSO
}

\section{SUMMARY}

The study was carried out in order to evaluate the capability of different cadmium concentrations to affect some alcoholic fermentation parameters, inclusive in cell recycling conditions, and the vinasse capability in order to attenuate the cadmium toxicity. The yeast were grown in yeast extract + dextrose medium with or without vinasse and in sugar-cane medium with or without vinasse. The measured parameters were yeast growth, trehalose and glycogen accumulation, alcohol and glicerol production, residual glucose and frutose in vine, fermentation rate, cell cadmium concentration, damages of the citoplasmatic membrane, cell viability and budding rate. The increase of cadmium levels showed a reduction on trehalose accumulation, yeast growth and cell viability. Watch all levels studied have accumulation of cadmium at yeast. Vinasse showed low toxicity, demonstrated by growth and trehalose reduction, but protected yeast cells very effectively against the 
toxic effects of cadmium. In the concentration of 0,025 mmol $\mathrm{L}^{-1}$ of cadmium, damages of the cellular wall were observed. Yeast viability decreased in parallel with trehalose content, apparently in response to cadmium toxicity. Therefore, trehalose concentrations may be an important indicator of cadmium stress on yeast. 


\section{INTRODUÇÃo}

Uma das características marcantes do homem é o imediatismo, estando sempre em busca de soluções de curto prazo, objetivando solucionar problemas circunstanciais, que, na maioria das vezes, acabam por protelar medidas que se fazem necessárias, gerando, a médio-longo prazo, problemas outros, de dimensões ainda maiores, cujas soluções, por vezes, são complexas e de custo elevado.

Práticas como a utilização do lodo de esgoto, a utilização de altas quantidades de adubos fosfatados, a deposição de resíduos de mineradoras e fundições e a queima de combustíveis fósseis entre outras, podem levar para os solos agrícolas altas quantidades dos mais variados metais pesados.

Em solos ácidos, onde a absorção e acúmulo de metais pesados por parte dos vegetais é facilitada, quantidades elevadas destes metais podem ser transportadas para o processo fermentativo. Devido ao fato das leveduras serem organismos bioacumuladores de metais pesados, as quantidades originalmente 
subtóxicas podem, com os reciclos fermentativos, virem a se tornar tóxicas, prejudicando o rendimento fermentativo. Desta maneira é interessante conhecer os possíveis efeitos destes metais em uma fermentação alcoólica.

O conhecimento da bioquímica e fisiologia desta toxicidade é ainda mais atraente quanto se pensa na utilização das leveduras para a confecção de filtros biológicos, com o propósito de descontaminar efluentes. Deve-se ainda levar em conta que a levedura é o organismo eucarioto mais simples e bioquimicamente estudado, sendo portanto um modelo adequado para o estudo dos mecanismos de toxicidade dos metais pesados.

O presente trabalho propõe a avaliação da toxicidade do cádmio em uma condição de reciclo de levedura, contemplando a observação de vários parâmetros fisiológicos e bioquímicos que poderiam ser afetados pelo metal. 


\section{REVISÃO DE LITERATURA}

\subsection{Os Metais Pesados no Meio Ambiente}

Recentes estudos sobre o comportamento dos metais pesados no ambiente, concluíram que muitos destes elementos, entre eles o cádmio, trazem sérios problemas devido a sua toxicidade, aliada aos fenômenos de bioacumulação (Robards \& Woursfold, 1991)

Os metais pesados compreendem em tomo de 40 elementos, que apresentam densidade mínima de $6,0 \mathrm{~g} \mathrm{~cm}^{-3}$ (Alloway, 1995). Muitos destes metais, como o níquel são essenciais para o crescimento de organismos eucariotos e/ou procariotos, sendo exigidos em concentrações muito pequenas. Outros, contudo, como o cádmio, não são essenciais para o crescimento celular, sendo extremamente tóxicos mesmo em baixas concentrações (Trevors et al., 1986; Volesky, 1990a). 


\subsection{Cádmio}

O cádmio é o elemento número 48 da tabela periódica, com um peso atômico de 112,4 . É medianamente denso $\left(8,6 \mathrm{~g} \mathrm{~cm}^{-3}\right)$, branco prateado, sendo um metal maleável com ponto de fusão $320,9^{\circ} \mathrm{C}$ e ebulição $765^{\circ} \mathrm{C}$ (Adriano, 1986; Reilly, 1991; Varma, 1986). Os níveis de cádmio em solos agrícolas alcançam a faixa de $8,896 \mathrm{nmol} \mathrm{kg}^{-1}$ à $0,02135 \mathrm{mmol} \mathrm{kg}^{-1}$, sendo o valor médio de 1,9571 $\mu \mathrm{mol} \mathrm{kg} \mathrm{kg}^{-1}$ (Adriano, 1986; Alloway, 1995), embora áreas vizinhas à fundições possam apresentar conteúdo de cádmio na camada superficial do solo entre 1,779 $\mu \mathrm{mol} \mathrm{kg}{ }^{-1}$ e 3,1136 mmol kg-1 (Adriano, 1986; Alloway, 1995; Ferguson, 1990). As concentrações de cádmio na hidrosfera alcançam de 0,6227 à $9,0738 \mathrm{nmol}$ $\mathrm{kg}^{-1}$ (Trevors et al., 1986), 88,9593 $\mathrm{nmol} \mathrm{kg}^{-1}$ na água potável (Volesky, 1990a) e 0,0889 à $0,3558 \mathrm{nmol} \mathrm{kg}^{-1}$ em água salgada (Robards \& Worsfold, 1991). Pacyna (1996) afirma que em 1983 a emissão global de cádmio na atmosfera variou de 3,1 a 12,0 ton $^{3}$. No Brasil, os teores de cádmio em solos se situam entre valores menores que 0,8896 até $3,5584 \mu \mathrm{mol} \mathrm{kg}{ }^{-1}$ (Ferguson, 1990).

A produção mundial de cádmio é oriunda dos processos de extração de zinco, chumbo e em menor escala do cobre. A remoção do cádmio é essencial para a produção destes metais, uma vez que sua presença afetaria as suas propriedades. Na fusão de minérios, e sua redução térmica a metal, o cádmio, sendo mais volátil e mais facilmente oxidável do que o zinco e o chumbo, é 
captado como partícula de óxido de cádmio (CdO) na saída do forno (Salgado, 1996a).

O uso industrial do cádmio deve-se ao seu baixo ponto de fusão $\left(320,9^{\circ} \mathrm{C}\right)$. A produção anual de cádmio está ao redor de $20 \times 10^{3}$ ton (Volesck, 1990a).

A aplicação principal do cádmio ( $34 \%$ do consumo total) é em revestimentos metálicos, os quais são muito resistentes à corrosão alcalina e marinha, devido à proteção catódica que oferecem. A indústria automobilística, a espacial e a de telecomunicações são os maiores usuários destes revestimentos. $\mathrm{O}$ segundo maior uso (23\%) é para pigmentos, geralmente à base de sulfeto de cádmio. Estes variam de amarelo à marrom, apresentado alta estabilidade térmica e sendo utilizados em tintas e vernizes plásticos. Outra área de aplicação é na industria de PVC (policloreto de vinila) e plásticos afins como estabilizador (15\% do total do consumo). Os sais de cádmio inibem eficazmente a degradação do PVC por radiação e/ou oxigênio. O uso de baterias de níquel / cádmio com eletrólito alcalino, outra área de aplicação, cresceu bastante nos últimos anos, devido a sua boa descarga e confiabilidade. O cádmio tem os seguintes usos menores: constituinte de soldas e ligas; produção de semicondutores e instrumentos fotovoltaicos; endurecedor na cura da borracha; constituinte do amalgama em odontologia (25\% cádmio : $75 \%$ mercúrio); na indústria do vidro; 
na fotografia, litografia e processo de gravura (Gerhardsson \& Skerfving, 1996; Midio \& Martins, 2000; Salgado, 1996a).

\subsection{Toxicidade do cádmio}

O cádmio é um elemento altamente tóxico, sendo descrito como um dos elementos traço mais perigosos presentes em alimentos e no ambiente do homem.

Sua toxicidade é altamente dependente das espécies atômicas, bem como de vários fatores físicos, químicos e biológicos (Adriano, 1986; Babich \& Stotzky, 1978). São importantes as diferenças, entre os vários compostos de cádmio, quanto a sua solubilidade (Tabela 1). Em geral, compostos solúveis como o cloreto de cádmio $\left(\mathrm{CdCl}_{2}\right)$ e acetato de cádmio $\left(\mathrm{Cd}\left(\mathrm{CH}_{3} \mathrm{CO}_{2}\right)_{2}\right)$ são mais absorvidos e mais tóxicos que compostos praticamente insolúveis como sulfeto de cádmio (CdS) (Mason, 1987).

Apesar de estar presente em quantidades preocupantes no ar, solo e água, o principal caminho de entrada do metal no organismo de seres humanos não expostos industrialmente são os alimentos contaminados (Elpo \& Freitas, 1995; Mídio \& Martins, 2000; Pacyna, 1996; Reilly, 1991). Gerhardsson \& Skerfving (1996), alertam que além dos alimentos, o tabaco é outra grande fonte de contaminação, correspondendo em torno de 1 a $2 \mu \mathrm{g}$ de cádmio por cigarro. Deste, $10 \%$ é inalado, sendo totalmente absorvido pelo organismo humano. 
Tabela 1. Propriedades físicas de alguns compostos de cádmio

\begin{tabular}{|c|c|c|c|c|c|c|c|}
\hline \multirow[b]{2}{*}{ Composto } & \multirow{2}{*}{$\begin{array}{l}\text { Fórmula } \\
\text { Química }\end{array}$} & \multirow{2}{*}{$\begin{array}{c}\text { Peso } \\
\text { Molecular }\end{array}$} & \multirow{2}{*}{$\begin{array}{l}\text { Ponto de } \\
\text { Fusão } \\
\left({ }^{\circ} \mathrm{C}\right)\end{array}$} & \multirow{2}{*}{$\begin{array}{l}\text { Ponto de } \\
\text { Ebulição } \\
\text { ('C) }\end{array}$} & \multirow{2}{*}{$\begin{array}{l}\text { Densidade } \\
\left(\mathrm{g} \mathrm{cm}^{-3}\right)\end{array}$} & \multicolumn{2}{|c|}{ Solubilidade } \\
\hline & & & & & & $\begin{array}{c}\text { Água } \\
(\mathrm{g} / 100 \mathrm{cc})\end{array}$ & $\begin{array}{l}\text { Solventes } \\
\text { orgânicos }\end{array}$ \\
\hline Cádmio & $\overline{\mathrm{Cd}}$ & 112,411 & 321 & 765 & 8,65 & insolúvel & ND* \\
\hline $\begin{array}{l}\text { Acetato de } \\
\text { cádmio }\end{array}$ & $\mathrm{Cd}\left(\mathrm{CH}_{3} \mathrm{CO}_{2}\right)_{2}$ & 232,50 & 321 & ND & 4,79 & 160 & ND* \\
\hline $\begin{array}{l}\text { Carbonato } \\
\text { de cádmio }\end{array}$ & $\mathrm{CdCO}_{3}$ & 172,43 & 321 & ND* & 4,26 & $\mathrm{pi}^{* *}$ & insolúvel \\
\hline $\begin{array}{l}\text { Cloreto de } \\
\text { cádmio }\end{array}$ & $\mathrm{CdCl}_{2}$ & 183,32 & 568 & 960 & 4,047 & 140 & $\begin{array}{c}\text { acetona } \\
\text { metanol } \\
\text { etanol }\end{array}$ \\
\hline $\begin{array}{l}\text { Hidróxido } \\
\text { de cádmio }\end{array}$ & $\mathrm{Cd}(\mathrm{OH})_{2}$ & 146,43 & 130 & ND* & 4,79 & qi*** & $\mathrm{ND}^{*}$ \\
\hline $\begin{array}{l}\text { Nitrato de } \\
\text { cádmio }\end{array}$ & $\mathrm{Cd}\left(\mathrm{NO}_{3}\right)_{2}$ & 236,43 & 350 & ND* & ND* & 326 a $60^{\circ} \mathrm{C}$ & $\begin{array}{c}\text { éter } \\
\text { acetona } \\
\text { álcool }\end{array}$ \\
\hline $\begin{array}{l}\text { Óxido de } \\
\text { cádmio }\end{array}$ & $\mathrm{CdO}$ & 128,40 & 900 & ND* & 8,15 & insolúvel & ND* \\
\hline $\begin{array}{l}\text { Silicato de } \\
\text { cádmio }\end{array}$ & $\mathrm{CdSiO}_{3}$ & 188,49 & 1.242 & ND* & 4,93 & insolúvel & ND* \\
\hline $\begin{array}{l}\text { Sulfato de } \\
\text { cádmio }\end{array}$ & $\mathrm{CdSO}_{4}$ & 208,47 & 1.000 & ND* & 4,691 & 76 a $0^{\circ} \mathrm{C}$ & $\begin{array}{c}\text { álcool } \\
\text { acetona }\end{array}$ \\
\hline
\end{tabular}

* não determinado; ${ }^{* *}$ praticamente insolúvel; ${ }^{* * *}$ quase insolúvel

Fonte: Adaptado de Mason, 1987.

Na sua vigésima segunda edição, realizada de 19 a 24 de março de 1990, o comitê do Códex Alimentárius sobre Contaminantes e Aditivos nos Alimentos, propôs níveis de cádmio de $0,00089 \mathrm{mmol} \mathrm{kg}^{-1}$ para vegetais e $0,00445 \mathrm{mmol} \mathrm{kg}$ ${ }^{-1}$ para cereais (Elpo \& Freitas, 1995). Contudo, os limites fixados pela legislação brasileira são de $0,00889 \mathrm{mmol} \mathrm{kg}^{-1}$.

O cádmio introduzido no organismo via oral é pouco absorvido sendo que cerca de $95 \%$ é eliminado. Porém, o restante se acumula nos rins e no figado, onde foi detectado que sua meia vida biológica é de 10 anos. A dose letal para um 
adulto de $60 \mathrm{~kg}$ é de 0,35g de cádmio (Gerhardsson \& Skerfving, 1996; Nogawa \& Kido, 1996).

Muito pouco é conhecido sobre o mecanismo de toxidade do cádmio. Porém, é bem conhecido que o cádmio se liga aos grupos sulfidril das proteínas. Se isto ocorre com uma enzima, esta pode ter suas funções inibidas (Mason, 1987; Gerhardsson \& Skerfving, 1996).

O cádmio, uma vez assimilado, se distribui no organismo. É principalmente encontrados nas células sanguíneas, parte ligado a metaloproteínas e parte circulando através do plasma, alcançando desta forma o fígado. No figado, o cádmio induz a produção de metaloproteínas (proteínas de baixo peso molecular e ricas em enxofre) no prazo de 4 a 24 horas. Esta proteína sequestra cádmio nas células do figado, atuando como agente desintoxicante. No entanto, somente $15 \%$ da carga corporal de cádmio é encontrada no figado, pois há uma liberação vagarosa do complexo metaloproteína-cádmio para o sangue. Este complexo é filtrado pelo glomérulo renal para a urina primária, como o são as outras proteínas de baixo peso molecular. Subsequentemente, o complexo é reabsorvido pelas células tubulares do rim, provavelmente por pinocitose. Nas células tubulares, lisosomas contendo enrimas digestivas, degradam rapidamente o complexo cádmio-proteína e liberam cádmio no citoplasma. As células tubulares tem a capacidade de produzir a sua própria metaloproteína, consequentemente evitando os efeitos tóxicos do cádmio não complexado. 
Quando a capacidade produtora de metaloproteína das células tubulares é excedida, os primeiros sinais de toxidade aparecem (Mason, 1987; Nogawa \& Kido, 1996; Salgado, 1996a; 1996b). Cerca de 50\% da carga corporal de cádmio é encontrada nos rins (Mason, 1987).

O rim é considerado o órgão crítico no acúmulo de cádmio. A falência do sistema renal é esperada como resultado da ingestão do metal. Entretanto, o único caso mundialmente aceito de toxidade de cádmio foi a célebre doença chamada “itai-itai”, observada no Japão, na cidade de Fochu, situada na bacia do rio Jintsu, em pessoas que se alimentaram com arroz e beberam água de arrozeirais que continham alta concentração do elemento. Ao todo, cerca de 100 pessoas morreram desta doença, cuja causa somente foi relacionada com o cádmio em 1961. Uma mineradora lançava seus rejeitos no rio que servia para irrigação dos arrozais e como fonte de água potável (Adriano, 1986; Nogawa \& Kido, 1996; Salgado, 1996b).

Quando a exposição em níveis altos de cádmio ocorre em pessoas com deficiência nutricional, efeitos diversos podem ocorrer. Especula-se que este foi o caso do evento trágico de "itai-itai", onde a ingestão continuada de cádmio por pessoas com deficiência de cálcio e vitamina $\mathrm{D}$ causou descaucificação dos ossos e dolorosas fraturas (Mídio \& Martins, 2000; Nogawa \& Kido, 1996). 


\subsection{Os Metais Pesados em Solos Agrícolas}

É conhecido que países altamente industrializados confrontam-se com sérios problemas de poluição do ar, água e do solo, sendo a atividade industrial uma das fontes principais da poluição de solos por metais pesados. As contaminações, em solos, ocorrem por resíduos da fabricação do cimento, pelas cinzas produzidas pela queima de combustíveis fósseis e lixos urbanos, rejeitos de mineradoras e fundições entre outras.

Uma forma direta de introdução de metais pesados em solos agrícolas é a utilização de fertilizantes fosfatados. Os níveis de cádmio nestes fertilizantes, por exemplo, variam amplamente, e dependem da origem das rochas de fosfato (Salgado, 1996a).

Recentemente difundiu-se a idéia da aplicação do lodo de esgoto em solos agrícolas em virtude do seu teor relativamente elevado de matéria orgânica, o que confere a este material um potencial considerável para melhorar a fertilidade do solo. $\mathrm{O}$ aumento do custo dos fertilizantes químicos, bem como a demanda de muita energia no processo de incineração de esgoto, torna a sua aplicação em solos agrícolas uma alternativa atraente (Jorge et al., 1991). Ao mesmo tempo, a utilização do lodo de esgoto diminui os problemas ambientais ocasionados pelo acúmulo e pela não utilização destas fontes poluidoras (Arteaga, 1996). 
Segundo Santos \& Tsutiya (1996) somente na grande São Paulo, estimase que para o ano de 2005 a produção de lodo de esgoto seco seria de 575 ton/dia (Tabela 2). Outros valores são também sugeridos (Tabela 3), como 726 ton/dia em 2010 e 766 ton/dia para 2015 (CEEJ, 1996*).

Tabela 2. Previsão da produção diária de lodo de esgoto nas principais estações de tratamento de esgoto da SABESP (ano 2005)

\begin{tabular}{lcc}
\hline \multicolumn{1}{c}{ LOCAL DA ETE } & TIPO DE TRATAMENTO & $\begin{array}{c}\text { PRODUÇ̃̃O DE LODO } \\
\text { BASE SECA (t/d) }\end{array}$ \\
\hline Barueri & L. A. Convencional & 227 \\
ABC & L. A. Convencional & 85 \\
Suzano & L. A. Convencional & 27 \\
Parque Novo Mundo & L. A. Convencional & 166 \\
São Miguel & L. A. Convencional & 55 \\
Franco da Rocha & Filtro Biológico & 9 \\
Perus & Filtro Biológico & 6 \\
Total de toneladas por dia na Rede Municipal de São Paulo & 575 \\
\hline
\end{tabular}

Fonte: Adaptado de Santos \& Tsutiya, 1996.

Tabela 3. Previsão de produção de Biossólidos nas ETEs da SABESP

\begin{tabular}{ccccccc}
\hline & \multicolumn{5}{c}{ Toneladas/dia em Base Seca } \\
Ano & Barueri & ABC & Suzano & Novo Mundo & São Miguel & total \\
\hline 1996 & 91 & 0 & 17 & 0 & 0 & 107 \\
2000 & 193 & 66 & 21 & 124 & 35 & 439 \\
2005 & 227 & 85 & 27 & 166 & 55 & 560 \\
2010 & 294 & 110 & 34 & 213 & 75 & 726 \\
2015 & 310 & 113 & 38 & 224 & 81 & 766 \\
\hline
\end{tabular}

Fonte: CEEJ, 1996.*

Porém, quando se considera o uso agronômico de resíduos contendo metais, devem ser feitas previsões do seu comportamento nos solos. Neste aspecto, a preocupação mais frequente diz respeito à solubilização, com

\footnotetext{
* CEEJ: Consórcio ETEP-ESTATICA-JNS. Diretrizes para implantaçāo da desidrataçāo mecânica nas ETEs PNM e SMG e secagem términa na ETE SMG. Relatório do contrato SABESP 14.002/93, rev 1, abril 1996.
} 
consequente deslocamento destes metais para a fase solúvel do solo, tornando estes disponíveis para a absorção pelos vegetais.

\subsection{Os Metais Pesados e a Fermentação Alcoólica}

Em sua maioria, plantas respondem ao aumento na concentração de metais no solo com a absorção dos mesmos (Gouvêa, 1995). A natureza destas respostas dependerá da sensibilidade individual, da intensidade (concentração e duração) da exposição, do metal propriamente dito e da forma como se encontra.

Quando a cana-de-açúcar, matéria prima para a fermentação é oriunda de solos ácidos, onde a absorção e o acúmulo de metais pesados pelas plantas é facilitado (Salgado, 1996b), quantidades consideráveis de cádmio podem ser encontradas nos colmos das plantas (Silva, 1995), podendo ser o metal transportado para o processo fermentativo.

O processo de fermentação normalmente utilizado no Brasil é o chamado Melle-Boinot, no qual as células de levedura recuperadas são recirculadas no processo, mantendo elevada a concentração celular e obtendo-se deste modo, um aumento do rendimento alcoólico, devido ao menor consumo de açúcar para o crescimento celular (Lima, 1983; Lopes, 1989;).

As leveduras que crescem em um meio de fermentação com concentrações, mesmo subtóxicas, de metais pesados, podem apresentar, devido 
ao fenômeno de bioacumulação, concentrações celulares destes metais, maiores que aquelas encontradas no mosto (Domingos, 1996; Grafl \& Schwantes, 1983a; Mariano-da-Silva \& Prado-Filho, 1998; Prado-Filho et al., 1998; Silva, 1998). Supõe-se que este problema deve se agravar ainda mais quando associado ao reciclo das leveduras.

O acúmulo de metais pesados por microrganismos é geralmente bifásico: uma rápida ligação com a superfície da célula, independente do metabolismo, é seguida de um acúmulo intracelular dependente do metabolismo e com gasto de energia (Belde et al., 1988; Brady \& Duncan, 1994; Norris \& Kelly, 1977; Valle \& Ulmer, 1972; Volesky, 1990b).

Neste acúmulo não dependente do metabolismo (biosorção), os cátions podem ser depositados na membrana via adsorção, precipitação orgânica ou ficarem adsorvidos à grupos aniônicos fixos, presentes na membrana da célula (Gadd, 1986; Volesky, 1990b). Algumas cepas de levedura produzem uma espécie de mussilagem polisacarídica que também pode promover a adsorção (Gadd, 1986). O acúmulo independente do metabolismo é seguido de outro, dependente do metabolismo (biacumulação), no qual os cátions são transportados através da membrana celular, provavelmente por proteínas de transporte, até o citossol, onde ficam ligados a metaloproteínas no vacúolo (Blackwell \& Tobin, 1999; Brady \& Duncan, 1994; Norris \& Kelly, 1977; Rösick et al., 1986; Volesky, 1990b). As metaloproteínas são ricas em cisteína (30\%), apresentando 
baixo peso molecular e alta capacidade de ligação com metais pesados em seus grupos -SH. Sua produção em leveduras é classicamente induzida por metais pesados, sendo considerada um mecanismo de destoxificação (Ecker et al., 1986; Macaskie \& Dean, 1990).

Segundo Assmann et al., (1996), o cádmio danifica a membrana celular da levedura, provocando a fluidização desta, induzindo a abertura dos canais de potássio e uma diminuição do nível intracelular deste. Este fenômeno foi estudado por vários pesquisadores (Assmann et al., 1996; Belde, et al, 1988; Blackwell \& Tobin, 1999; Borst-Pauwels, 1988; Gadd \& Mowll, 1983; Kessels et al., 1985; Theuvenet et al., 1987), sendo que Kessels et al., (1985) determinaram que uma célula de Saccharomyces cerevisiae perde cerca de 22 ions $\mathrm{K}^{+}$para cada ion $\mathrm{Cd}^{+2}$ absorvido.

O acúmulo de cádmio no vacúolo pode causar o desalojamento do cálcio de seus sítios vaculares, provocando um aumento de ions $\mathrm{Ca}^{+2}$ livres no citossol, os quais podem causar a abertura de canais de saída de potássio e a perda deste para o meio. $\mathrm{O}$ cádmio intracelualar pode também agir diretamente sobre os grupos SH- dos canais de saída do potássio, provocando a abertura destes e a consequente perda de potássio (Assmann et al., 1996).

Danos na enzima $\mathrm{H}^{+}$-ATPase também foram relatados como causados pelo cádmio em leveduras (Karamushka et al., 1996). Um componente chave na membrana plasmática é $\mathrm{H}^{+}$-ATPase, a qual cria um gradiente eletroquímico de 
prótons através da membrana que controla o transporte de uma variedade de solutos inorgânicos e orgânicos, como a glicose (Brock et al, 1994; Griffin, 1994; Smith and Wood, 1996). Esta enzima é claramente responsável por diversos fatores físico-químicos e nutricionais, e é usualmente um indicador de estresse, incluindo o causado pelos metais pesados (Assmann et al., 1996)

O cádmio também pode afetar a entrada de glicose na célula de levedura quando se encontra ligado aos sítios aniônicos da membrana plasmática. Vários autores (Nakamura, 1965; Stevenink \& Booij, 1964; Stevenink, 1966) relataram que o transporte de glicose para dentro da célula de levedura é inibido por metais pesados e que esta inibição pode estar envolvida com a interação destes metais (por exemplo níquel, cobalto e cádmio) com os polifosfatos da membrana, causando uma mudança conformacional em alguns sítios ativos, o que inviabilizaria o acoplamento com a glicose.

Os polifostatos se situam do lado exterior da membrana plasmática (Tijssen, 1981) e atuam acoplando a glicose em seus sítios específicos e auxiliando no transporte desta através da membrana plasmática, estando envolvidos no processo de fosforilação enzimática (Brock et al, 1994; Griffin, 1994; Smith and Wood, 1996).

As relações entre o cádmio e uma célula de levedura podem ser observadas na Figura 1. 


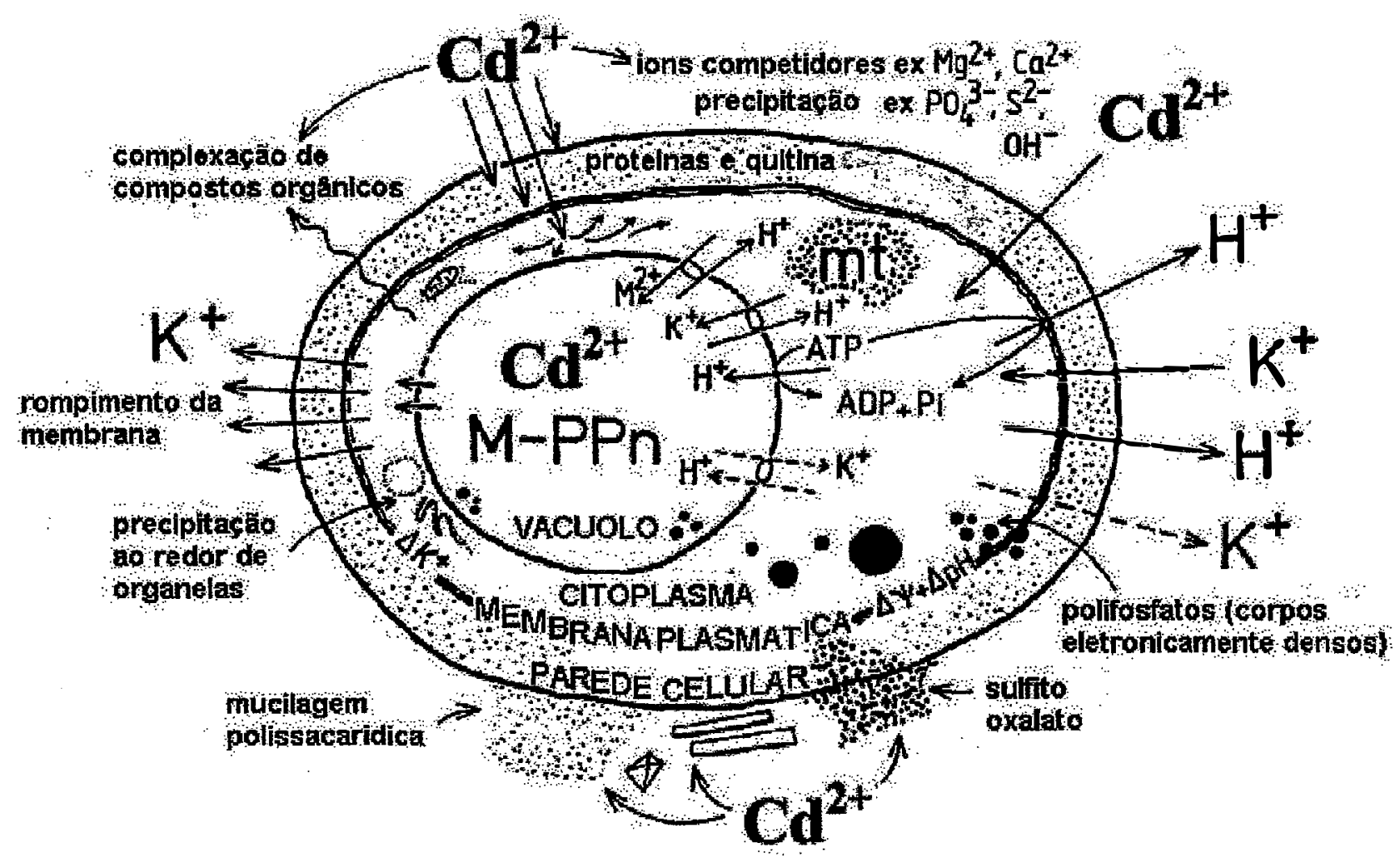

Figura 1: Alguns dos mecanismos que envolvem a absorção de cádmio por leveduras. Sendo: $\left(\mathrm{Cd}^{+2}\right)=$ cátion cádmio; $\left(\mathrm{K}^{+}\right)=$cátion potássio; $\left(\mathrm{H}^{+}\right)=$ânion hidrogênio; $\left(\mathrm{Mg}^{2+}\right)$ = cátion magnésio; $\left(\mathrm{Ca}^{2+}\right)=$ cátion cálcio; $\left(\mathrm{S}^{2-}\right)=$ ânion enxofre; $\left(\mathrm{PO}_{4}{ }^{3-}\right)=$ ânion fosfato; $(\mathrm{OH})=$ ânion hidróxido; $(\mathrm{M}-\mathrm{PPn})=$ metal ligado com polifosfatos; $(\mathrm{mt})=$ metaloproteínas; $(\mathrm{Pi})=$ fosfato inorgânico; $(\Delta \psi)=$ potencial da membrana; $(\Delta \mathrm{pH})=$ gradiente de $\mathrm{pH}$ através da membrana plasmática; $\left(\Delta \mathrm{K}^{+}\right)=$gradiente de potássio através da membrana; $(\mathrm{ATP})=$ adenosina trifosfato; $(\mathrm{ADP})=$ adenosina difosfato .

Fonte: Gadd (1986)

\subsection{Vinhaça}

A vinhaça, resíduo da fabricação do álcool, é produzida em média, na proporção de 13 litros para cada litro de álcool. É o principal efluente das destilarias de álcool. Por sua composição em matéria orgânica, apresenta elevado 
índice de DBO (demanda bioquímica de oxigênio), caracterizando-se, portanto, como material altamente poluente, quando descartado em cursos d'água (Silva \& Orlando-Filho, 1981).

Tendo em vista os nutrientes (principalmente o potássio) e a matéria orgânica que a vinhaça apresenta, sua utilização nas lavouras de cana-de-açúcar, como substituto parcial das adubações orgânicas tem sido incrementada em nosso meio (Glória \& Orlando-Filho, 1983; Orlando-Filho et al., 1980; Silva \& Orlando-Filho, 1981).

A composição da vinhaça é extremamente variável, dependendo principalmente do tipo de matéria-prima empregada no preparo do mosto (melaço, caldo de cana-de-açúcar ou misto), procedência ou localização da destilaria, época de amostragem e tipo do processo utilizado na fabricação do álcool (Silva \& Orlando-Filho, 1981).

De uma maneira geral, podemos considerar os dados apresentados na Tabela 4 como a composição média de uma vinhaça típica. 
Tabela 4. Composição média de três tipos de vinhaça, provenientes de diferentes tipos de meio de fermentação.

\begin{tabular}{cccc}
\hline $\begin{array}{c}\text { Elemento } \\
\mathrm{Kg} / \mathrm{m}^{3}\end{array}$ & Mosto de melaço & $\begin{array}{c}\text { Tipo de vinhaça } \\
\text { Mosto misto }\end{array}$ & Mosto de caldo \\
\hline $\mathrm{N}$ & 0,57 & 0,48 & 0,28 \\
$\mathrm{P}_{2} \mathrm{O}_{5}$ & 0,10 & 0,09 & 0,09 \\
$\mathrm{~K}_{2} \mathrm{O}$ & 3,95 & 3,34 & 1,29 \\
$\mathrm{CaO}$ & 1,85 & 1,33 & 0,13 \\
$\mathrm{MgO}$ & 0,98 & 0,58 & 0,21 \\
$\mathrm{M.O}$ & 37,30 & 28,97 & 22,31 \\
$\mathrm{pH}$ & 4,2 & 4,4 & 3,7 \\
\hline
\end{tabular}

Fonte: Adaptado de Silva \& Orlando-Filho, 1981

2.7 Influência de outros cátions e de compostos orgânicos na atenuação da toxicidade de metais pesados:

A atividade biológica dos "cátions" metais pesados pode ser profundamente afetada pela presença de outros cátions. Kessels et al., (1985) e Norris \& Kelly (1977) relatam que a adição de $\mathrm{CaSO}_{4}\left(0,2 \mathrm{mmol} \mathrm{L}^{-1}\right)$ ao meio de fermentação diminuiu a absorção de cádmio por Saccharomyces cerevisiae, além de atenuar a perda de potássio provocada pelo cádmio. Segundo os autores, o tratamento com cálcio pode ter afetado a ligação do cádmio com os grupos sulfidril da superfície da célula de levedura. Cálcio e cádmio, devido a similaridade do tamanho dos cátions $\left(\mathrm{Cd}^{+2}\right.$ raio iônico $=0,097 \mathrm{~nm} ; \mathrm{Ca}^{+2}$ raio iônico $=0,099 \mathrm{~nm}$ segundo Pauling, 1960), são altamente competitivos pelos sítios de adsorção de metais em leveduras. 
Assmann et al., (1996) relataram que enquanto $\mathrm{Cd}^{+2}$ inibiu o crescimento, a respiração e a absorção de glicose por parte da levedura Schizossacharomyces pombe, em concentrações consideradas baixas pelos autores (abaixo de $0,1 \mathrm{mmol}$ $\left.\mathrm{L}^{-1}\right), 0,2 \mathrm{mmol} \mathrm{L}^{-1}$ de zinco tiveram efeitos estimulantes sobre estes parâmetros. Os autores afirmaram que zinco manteve a fluidez normal da membrana celular impedindo a fluidização causada pelo cádmio. Schnetler \& Zimmermann, (1993), trabalhando com eletrofusão de protoplastos da levedura Hansenula polymorpha, relataram que o zinco impediu o rompimento da membrana após o processo. Realmente, o zinco tem mostrado atuar como estabilizador da estrutura das membranas celulares, participando, por exemplo, do controle da mobilidade lateral dos lipídios da membrana e da permeabilidade para a água (Rygol et al., 1992). Porém a concentração de zinco utilizada é muito importante. Grafl \& Schwantes (1983c) e Grafl \& Schwantes (1983b) demonstraram que enquanto concentrações de $0,1 \mathrm{mmol} \mathrm{L}^{-1}$ de zinco protegem a levedura Saccharomyces cerevisiae de uma dose de $0,1 \mathrm{mmol} \mathrm{L}^{-1}$ de cádmio, $10 \mathrm{mmol} \mathrm{L}^{-1}$ de zinco potencializam a toxicidade.

Além deste efeito protetor em baixas concentrações, o zinco apresenta alta eletroafinidade com o cádmio, podendo vir a formar complexos com este, competir pelos sítios de ligação na membrana e pelos sistemas de transporte para entrada na célula (Assmann et al., 1996; Endo \& Shaikh, 1993). 
A ação tóxica dos metais pesados pode tembém ser afetada pela matéria orgânica do meio, existindo duas possíveis explicações para a este fato. A primeira é que a matéria orgânica reage com o metal para formar compostos que são menos tóxicos. A segunda é que o metal é adsorvido na superficie das partículas coloidais, se tornando menos tóxico ou atóxico (Bagy et al., 1991). Na matéria orgânica, ação individual de grupos quelantes e sequestradores, com radicais como $\mathrm{CN}^{-}, \mathrm{R}-\mathrm{S}^{-},-\mathrm{SH}^{-}, \mathrm{NH}_{2}^{-}$, grupos contendo nitrogênio e átomos enxofre é desconhecida, apesar de se saber que o cádmio forma fortes ligações com estes compostos (Remacle, 1990). 


\section{MATERIAL E MÉTODOS}

\subsection{Ensaio 1}

\subsubsection{Procedimento experimental}

\subsubsection{Preparo da vidraria}

Toda a vidraria reutilizável foi previamente imersa, por 4 horas, em uma solução de lavagem $\left(\mathrm{HNO}_{3}, \mathrm{HCl}\right.$ e água, na proporção 1:2:9) sendo a seguir enxaguada com água deionizada e seca em estufa a $80^{\circ} \mathrm{C}$ (McDaniel, 1992).

\subsubsection{Preparo das soluções}

Para limitar a possível contaminação, todas as soluções utilizadas foram preparadas com água ultra pura (Sistema Millipore Milli-Q de purificação).

\subsubsection{Cepas utilizadas}

Utilizou-se as leveduras Saccharomyces cerevisiae PE-2 e Saccharomyces cerevisiae IZ-1904, ambas caracterizadas pelo método de cariotipagem (Basso et al., 
1993), e oriundas da Coleção de Leveduras do Departamento de Ciências Biológicas (ESALQ/USP). Tais leveduras são amplamente empregadas pelo parque industrial brasileiro, e apresentam baixa (IZ-1904) e alta (PE-2) capacidade de sobrevivência nas dornas.

\subsubsection{Pré-crescimento das leveduras}

Partindo de uma cultura pura (liofilizada), as leveduras foram reativadas por 48 horas a $32^{\circ} \mathrm{C}$ em meio YEPD (extrato de levedura $1 \%$, peptona $1 \%$ e dextrose 2\%) e pré-crescidas anaerobicamente a $30^{\circ} \mathrm{C}$ em meio de melaço com $6 \%$ de açúcares redutores totais (ART), suplementado com $\mathrm{KH}_{2} \mathrm{PO}_{4}\left(8,36 \mathrm{mmol} \mathrm{L}{ }^{-1}\right)$, $\left(\mathrm{NH}_{4}\right)_{2} \mathrm{SO}_{4}\left(5 \mathrm{mmol} \mathrm{L}^{-1}\right)$, uréia $\left(38,75 \mathrm{mmol} \mathrm{L}^{-1}\right), \mathrm{MgSO}_{4} \cdot \mathrm{H}_{2} \mathrm{O}\left(3,57 \mathrm{mmol} \mathrm{L}{ }^{-1}\right)$, $\mathrm{ZnSO}_{4} \cdot 7 \mathrm{H}_{2} \mathrm{O}\left(0,10 \mathrm{mmol} \mathrm{L}{ }^{-1}\right), \mathrm{MnSO}_{4} \cdot \mathrm{H}_{2} \mathrm{O}\left(0,12 \mathrm{mmol} \mathrm{L}{ }^{-1}\right)$ e ácido linoleico $(0,11$ mmol L $\left.{ }^{-1}\right)$ e esterilizado $\left(121^{\circ} \mathrm{C} / 1 \mathrm{~atm} / 20\right.$ minutos $)$. Após o crescimento as células foram coletadas por centrifugação $(800 \mathrm{G}, 20 \mathrm{~min})$ e ressuspendidas em água destilada estéril a um concentração de $1 \%$ na massa úmida $(\mathrm{m} / \mathrm{v})$.

\subsubsection{Ensaio de crescimento}

Os crescimentos foram levados a efeito em $75 \mathrm{~mL}$ de meio YED (extrato de levedura $1 \%$ e dextrose $2 \%$ ) autoclavado ( $1 \mathrm{~atm}, 121^{\circ} \mathrm{C}$ por 20 minutos), em frascos erlenmeyers de $125 \mathrm{~mL}$, tapados com folha de alumínio e acrescidos com acetato de cádmio $\left(\mathrm{CdC}_{4} \mathrm{H}_{6} \mathrm{OH}\right.$. 2 $\left.\mathrm{H}_{2} \mathrm{O}\right)$, de forma que as concentrações finais do metal fossem $0 ; 0,05 ; 0,10$ e $0,50 \mathrm{mmol} \mathrm{L}^{-1}$. Todos os tratamentos foram realizados com 3 
repetições. $\mathrm{O}$ valor de $\mathrm{pH}$ dos meios foi ajustado a 5,5 utilizando uma solução de $\mathrm{H}_{2} \mathrm{SO}_{4} 0,1 \mathrm{~mol} \mathrm{~L}$. Os frascos contendo os meios foram inoculados em condições assépticas, com $1 \mathrm{~mL}$ da suspensão a 1\% da respectiva levedura (PE-2 ou IZ-1904), conforme o tratamento, e incubados a $30^{\circ} \mathrm{C}$, sob agitação $(120 \mathrm{rpm})$ por 18 horas.

\subsubsection{Análises do crescimento}

Em tempos determinados durante o crescimento $(0,2,4,6,8,19,12,14,16$ e 18 horas), $1 \mathrm{~mL}$ da suspensão de células foi retirado e transferido para tubos de ensaio com $9 \mathrm{~mL}$ de água deionizada estéril. A concentração de células foi determinada por leitura turbidiométrica, a $570 \mathrm{~nm}$, em espectrofotômetro Bausch \& Lomb, modelo Spectronic 88. O crescimento foi então avaliado pela conversão das leituras em concentração de biomassa (g $100 \mathrm{~mL}^{-1}$ de meio) através de reta padrão anteriormente estabelecida para cada levedura (Anexos 1 e 2). Todos os tratamentos foram feitos em triplicata.

\subsubsection{Taxa de viabilidade, taxa de brotamento e contaminação bacteriana}

No final do ensaio (18 horas), foram retirados $0,5 \mathrm{~mL}$ de cada suspensão, sendo as amostras diluídas e coradas com eritrosina e observadas em microscópio ótico para avaliação da viabilidade, taxa de brotamento e contaminação bacteriana (Amorim et al., 1989). 


\subsubsection{Análise do etanol}

Ao final do crescimento (18 horas), o etanol foi dosado no vinho delevurado mediante destilação com vapor (em microkjeldhal) seguido de densimetria eletrônica em densímetro Anton Paasr, modelo DMA 48 (Zago et al., 1989).

\subsubsection{Análise de trealose}

A trealose foi extraída de $60 \mathrm{mg}$ (matéria fresca) de células com $2 \mathrm{~mL}$ de ácido tricloroacético $0,5 \mathrm{~mol} \mathrm{~L}^{-1}$, em banho de gelo por 20 minutos (a suspensão foi frequentemente agitada) seguida de centrifugação e separação do extrato sobrenadante (Trevelyan \& Harrison, 1956a, 1956b). Em duplicata, 0,2 mL de cada sobrenadante foram transferidos para tubos Pyrex diluindo-se com 0,3 $\mathrm{mL}$ de água. A seguir, foi adicionado $5 \mathrm{~mL}$ do reagente antrona $(125 \mathrm{mg}$ antrona e $2,5 \mathrm{~g}$ tiouréia em uma mistura de $65,2 \mathrm{~mL}$ de água e $187,5 \mathrm{~mL}$ de $\mathrm{H}_{2} \mathrm{SO}_{4}$ ). A reação. transcorreu em banho de água em ebulição por 10 minutos, seguida de resfriamento por 20 minutos em sala escura. A intensidade de cor formada foi mensurada em colorímetro (Klett-Summerson) a $620 \mathrm{~nm}$ (Brin, 1966) e com reta padrão previamente estabelecida calculou-se os teores de trealose.

\subsubsection{Análise estatística}

A análise de variância (teste de $\mathrm{F}$ ) foi utilizada para analisar as variáveis crescimento, células viáveis e teor de trealose, seguida de uma análise seguindo um esquema fatorial $5 \times 2$ no delineamento inteiramente casualizado, com modelo 
classificação cruzada dupla e 3 repetições. As comparações de médias foram feitas pelo teste de comparações múltiplas de Tukey (Snedecor \& Cochran, 1967). Os resultados da análise estatística podem ser observados no Anexo 4.

\subsection{Ensaio 2}

\subsubsection{Procedimento experimental}

\subsubsection{Preparo da vidraria}

Toda a vidraria reutilizável foi preparada conforme descrito no item 3.1.1.1.

\subsubsection{Preparo das soluções}

Todas as soluções utilizadas foram preparadas conforme descrito no item

3.1.1.2.

\subsubsection{Obtenção da vinhaça}

Inicialmente fermentou-se um meio preparado com melaço com $15 \%$ de ART, previamente esterilizado (autoclavagem $1 \mathrm{~atm}, 121^{\circ} \mathrm{C}$ por 20 minutos) e inoculado com $10 \%$ (v/v) de levedura PE-2. A fermentação foi conduzida a $32^{\circ} \mathrm{C}$, separando-se ao final desta as leveduras por centrifugação (800 G, $15 \mathrm{~min})$, sendo que o vinho delevurado obtido foi fervido por 1 hora para evaporar o álcool e reconstituído o volume original com água destilada. A vinhaça assim obtida foi caracterizada pelos seguintes parâmetros: $\mathrm{pH} 4,98 ; 0,07 \%$ de álcool; densidade 
1,$0261 ; 0,495 \%$ de glicerol; $0,111 \%$ de frutose; $0,059 \%$ de glicose; $0,162 \%$ de AR e 0,224 de ART. A caracterização dos componentes minerais da vinhaça utilizada pode ser encontrada no Anexo 5.

\subsubsection{Cepa utilizada}

Utilizou-se a levedura Saccharomyces cerevisiae PE-2, caracterizada pelo método de cariotipagem (Basso et al., 1993), e oriunda da Coleção de Leveduras do Departamento de Ciências Biológicas (ESALQ/USP).

\subsubsection{Pré-crescimento da levedura}

A levedura foi reativada conforme descrito no item 3.1.1.4.

\subsubsection{Ensaio de crescimento}

Os crescimentos foram levados a efeito em $75 \mathrm{~mL}$ de meio YED (extrato de levedura $1 \%$ e dextrose $2 \%$, autoclavado a $1 \mathrm{~atm}, 121^{\circ} \mathrm{C}$ por 20 minutos) em frascos erlenmeyers de $125 \mathrm{~mL}$, tapados com folha de alumínio e acrescidos com acetato de cádmio $\left(\mathrm{CdC}_{4} \mathrm{H}_{6} \mathrm{OH} .2 \mathrm{H}_{2} \mathrm{O}\right)$, de forma que as concentrações finais do metal fossem 0,$0 ; 0,10$ e $0,50 \mathrm{mmol} \mathrm{L}^{-1}$ e com as diferentes proporções de vinhaça no meio (15 e $30 \%$ em volume). Todos os tratamentos foram realizados em 3 repetições. $\mathrm{O} \mathrm{pH}$ dos meios foi ajustado a 5,5 utilizando uma solução de $\mathrm{H}_{2} \mathrm{SO}_{4} 0,1 \mathrm{mmol} \mathrm{L}{ }^{-1}$ ou de $\mathrm{NaOH} 0,1 \mathrm{mmol} \mathrm{L}^{-1}$. Os frascos contendo os meios foram inoculados em condições 
assépticas, com $2 \mathrm{~mL}$ da suspensão $1 \%(\mathrm{~m} / \mathrm{v})$ da levedura (PE-2), conforme o tratamento, e incubados a $30^{\circ} \mathrm{C}$, sob agitação $(120 \mathrm{rpm})$ por 18 horas.

\subsubsection{Análises do crescimento}

Os crescimentos foram avaliados em diferentes tempos $(0,2,4,6,8,10,12$, 14, 16 e 18 horas), conforme protocolo do Ensaio 1, igualmente com 3 repetições. A reta padrão utilizada para a conversão das leituras espectrofotométricas em g 100 $\mathrm{mL}^{-1}$ encontra-se no Anexo 6.

3.2.1.8. Taxa de viabilidade, taxa de brotamento e contaminação bacteriana

A taxa de viabilidade, a taxa de brotamento e a contaminação bacteriana foram determinadas conforme descrito no item 3.1.1.7.

\subsubsection{Análise do etanol}

O etanol foi dosado ao final das fermentações (18 horas), conforme descrito no item 3.1.1.8.

\subsubsection{Análise de trealose}

No final das fermentações, o teor de trealose das leveduras submetidas aos direfentes tratamentos, foi dosado como descrito no item 3.1.1.9. 


\subsubsection{Análise estatística}

A análise de variância (teste de F) foi utilizada para analisar as variáveis crescimento, células viáveis, taxa de brotamento, produção de álcool e teor de trealose, seguida de uma análise sob o esquema fatorial $4 \times 3$ no delineamento inteiramente casualizado, com modelo classificação cruzada e 3 repetições. As comparações de médias foram feitas pelo teste de comparações múltiplas de Tukey (Snedecor \& Cochran, 1967).

Os resultados da análise estatística podem ser observados no Anexo 8.

\subsection{Ensaio 3}

\subsubsection{Procedimento experimental}

\subsubsection{Preparo da vidraria}

Toda a vidraria reutilizável foi previamente preparada conforme descrito no item 3.1.1.1.

\subsubsection{Preparo das soluções}

Todas as soluções utilizadas foram preparadas conforme descrito no item 3.1.1.2. 


\subsubsection{Cepa utilizada}

Utilizou-se a levedura Saccharomyces cerevisiae PE-2, caracterizada pelo método de cariotipagem (Basso et al., 1993), e oriunda da Coleção de Leveduras do Departamento de Ciências Biológicas (ESALQ/USP).

\subsubsection{Preparo do caldo-de-cana}

Para o preparo dos mostos foi utilizado caldo de cana com $24 \%$ de ART. A caracterização dos componentes minerais do caldo utilizado se encontra no anexo 5. Para as fermentações, o caldo foi previamente esterelizado (1 ATM / 20 minutos / $121^{\circ} \mathrm{C}$ ) e diluído com água destilada esterelizada até $20,58 \%$ de ART.

\subsubsection{Pré-crescimento da levedura}

Partindo de uma cultura pura (liofilizada), a levedura foi reativada conforme descrito no item 3.1.1.4.

\subsubsection{Ensaio de fermentação}

As fermentações foram conduzidas em tubos de centrífuga de vidro com $150 \mathrm{~mL}$ de capacidade, contendo uma quantidade inicial de levedura de $8,00 \mathrm{~g}$ (massa úmida). A massa de levedura foi suspensa em $20 \mathrm{~mL}$ de água destilada esterilizada, submetida à uma acidificação com $\mathrm{H}_{2} \mathrm{SO}_{4}$ até $\mathrm{pH}=2,5$ e mantida em repouso por 1 hora, tentando imitar o tratamento ácido conduzido no processo industrial. Em seguida foram adicionados $60 \mathrm{~mL}$ de mosto, acrescido com acetato de cádmio $\left(\mathrm{CdC}_{4} \mathrm{H}_{6} \mathrm{OH}\right.$. $\left.2 \mathrm{H}_{2} \mathrm{O}\right)$, de forma que as concentrações finais do metal nos 
diferentes tratamentos fossem com 0,$0 ; 0,001 ; 0,005 ; 0,025$ e $0,05 \mathrm{mmol} \mathrm{L}^{-1}$. As fermentações foram conduzidas à $33-34^{\circ} \mathrm{C}$, sendo os tubos tapados com folha de alumínio para se evitar perdas, por evaporação, de etanol e água. Ao final de cada fermentação, cuja velocidade foi estimada pela perda de peso $\left(\mathrm{CO}_{2}\right)$ a cada hora, o fermento foi separado mediante centrifugação a $800 \mathrm{G}$, pesado e reutilizado em uma fermentação subsequente, sempre precedida do tratamento ácido, compreendendo 6 ciclos fermentativos.

\subsubsection{Taxa de viabilidade, taxa de brotamento e contaminação bacteriana}

No final de cada dia, foram retirados $0,5 \mathrm{~mL}$ de cada suspensão, sendo a taxa de viabilidade, taxa de brotamento e contaminação bacteriana determinadas conforme item 3.1.1.7.

\subsubsection{Análise do etanol}

Ao final de cada ciclo fermentativo, o etanol foi dosado como descrito no item 3.1.1.8.

3.3.1.9 Análise do glicerol e de açúcares residuais (sacarose, glicose e frutose) no vinho

Ao final de cada ciclo fermentativo, o glicerol e os açúcares residuais foram dosados nos vinhos delevurados mediante cromatografia líquida de alta eficiência (CLAE), empregando-se o cromatógrafo iônico Dionex DX300 equipado com 
coluna Carbopack PAl e detector baseado na amperometria de pulso com eletrodo de ouro, empregando-se como fase móvel $\mathrm{NaOH} 100 \mathrm{~mm} \mathrm{~L}^{-1}$ a um fluxo de $1 \mathrm{~mL}$ $\min ^{-1}$.

\subsubsection{Densidades dos vinhos delevurados}

Ao final de cada ciclo fermentativo, a desidade dos vinhos delevurados foi determinada mediante utilização de densímetro digital (Anton Paar, modelo DMA 48).

\subsubsection{1 pH dos vinhos delevurados}

Ao final de cada ciclo fermentativo, o $\mathrm{pH}$ dos vinhos delevurados foi estimado diretamente em potenciômetro digital (Digimed, modelo DPH2).

\subsubsection{Análise de glicogênio}

Ao final do sexto ciclo fermentativo, o glicogênio foi extraído mediante digestão de $60 \mathrm{mg}$ de massa úmida de levedura com $1 \mathrm{~mL}$ de $\mathrm{Na}_{2} \mathrm{CO}_{3} 0,25 \mathrm{~mol} \mathrm{~L}^{-1}$ à $95^{\circ} \mathrm{C}$ por 90 minutos em tubos fechados. A mistura foi ajustada a pH 5,2 pela adição de ácido acético $1 \mathrm{~mol} \mathrm{~L}^{-1}$ e acetato de sódio $0,2 \mathrm{~mol} \mathrm{~L}^{-1}$, sendo então o extrato submetido à hidrólise enzimática com amiloglicosidase (E.C. 3.2.1.3.) por 2 horas à $37^{\circ} \mathrm{C}$, e posterior dosagem espectrométrica a $540 \mathrm{~nm}$ da glicose liberada, após reação com glicose-oxidase (E.C. 1.1.3.4.), peroxidase (E.C. 1.11.1.7.) ácido 
clorídrico e ortodianisidina por 40 minutos à $30^{\circ} \mathrm{C}$ e pH 6,0 (Parrou \& Francois, 1997).

\subsubsection{Análise de trealose}

Ao final do sexto ciclo fermentativo, a trealose foi extraída e mensurada conforme descrito no item 3.1.1.9.

\subsubsection{Análise de nitrogênio}

Da biomassa seca foi quantificado o nitrogênio total, segundo o método Microkjeldahl (Silva, 1990). As amostras foram inicialmente digeridas com $\mathrm{H}_{2} \mathrm{SO}_{4} \mathrm{e}$ $\mathrm{H}_{2} \mathrm{O}_{2}$ em bloco digestor à $350^{\circ} \mathrm{C}$. Quando as amostras estavam mineralizadas, fez-se a destilação com $\mathrm{NaOH} 45 \%$, sendo o destilado recebido em uma solução de $\mathrm{H}_{3} \mathrm{BO}_{3}$ e mistura indicadora (vermelho de metila e verde de bromocresol) o qual foi posteriormente titulado com $\mathrm{H}_{2} \mathrm{SO}_{4}$ padronizado.

\subsubsection{Cálculo do rendimento fermentativo}

O rendimento fermentativo foi calculado baseado na estequiometria de que $100 \mathrm{~g}$ de ART propícia a formação de $51,11 \mathrm{~g}(64,75 \mathrm{~mL})$ de etanol (rendimento 100\%). Para diminuir os erros de medidas de volume optou-se por pesagens e posterior conversão dos pesos (de mosto, de vinho, de levedura) em volumes. Assim, por densimetria, determina-se as densidades do mosto e do vinho delevurado. A densidade da levedura é estimada em 1,04-1,06, e tal valor 
corresponde ao peso (em gramas) de $1 \mathrm{~mL}$ de massa úmida centrifugada (800 G). Para se evitar perdas de fermento de um reciclo fermentativo para outro, as análises de teores alcoólicos são conduzidas no vinho delevurado. Para os cálculos de rendimento em etanol, descontou-se o etanol oriundo da fermentação anterior presente na levedura e levando-se em consideração que o volume de exclusão da matéria sólida da levedura (membranas, paredes celulares, etc.) representa 30,70\% (v/m) da massa úmida centrifugada (800 G (Basso, comunicação pessoal).

\subsubsection{Análise estatística}

A análise de variância (teste de F) foi utilizada para analisar as variáveis, seguida de uma análise sob o esquema parcelas subdivididas no tempo em delineamento blocos ao acaso, com modelo classificação cruzada e 3 repetições. As comparações de médias foram feitas pelo teste de comparações múltiplas de Tukey (Snedecor \& Cochran, 1967). Os resultados da análise estatística podem ser observados no Anexo 15.

\subsection{Ensaio 4}

\subsubsection{Procedimento experimental}

\subsubsection{Preparo da vidraria}

Toda a vidraria reutilizável foi previamente preparada conforme descrito no item 3.1.1.1. 


\subsubsection{Preparo das soluções}

Todas as soluções utilizadas foram preparadas conforme descrito no item 3.1.1.2.

\subsubsection{Obtenção da vinhaça}

A vinhaça foi obtida conforme descrito no item 3.2.1.1.

\subsubsection{Preparo do caldo-de-cana}

Para o preparo dos mostos foi utilizado caldo de cana com $24 \%$ de ART. A caracterização dos componentes minerais do caldo utilizado se encontra no anexo 5. Para as fermentações, o caldo foi previamente esterelizado (1 ATM / 20 minutos / $121{ }^{\circ} \mathrm{C}$ ) e diluído com água destilada esterelizada e/ou vinhaça, conforme o tratamento, até $20,7 \mathrm{ART}$.

\subsubsection{Cepa utilizada}

Utilizou-se a levedura Saccharomyces cerevisiae PE-2, caracterizada pelo método de cariotipagem (Basso et al., 1993), e oriunda da Coleção de Leveduras do Departamento de Ciências Biológicas (ESALQ/USP).

\subsubsection{Pré-crescimento da levedura}

Partindo de uma cultura pura (liofilizada), a levedura foi reativada conforme descrito no item 3.1.1.4. 


\subsubsection{Ensaio de fermentação}

As fermentações foram conduzidas em tubos de centrífuga de vidro com 150 $\mathrm{mL}$ de capacidade, contendo uma quantidade inicial de levedura de 8,00 $\mathrm{g}$ (massa úmida). A massa de levedura foi suspensa em $20 \mathrm{~mL}$ de água destilada esterilizada (ou vinhaça, de acordo com o tratamento), submetida à uma acidificação com $\mathrm{H}_{2} \mathrm{SO}_{4}$ até $\mathrm{pH}=2,5$ e mantida em repouso por 1 hora, tentando imitar o tratamento ácido conduzido no processo industrial. Em seguida foram adicionados $60 \mathrm{~mL}$ de

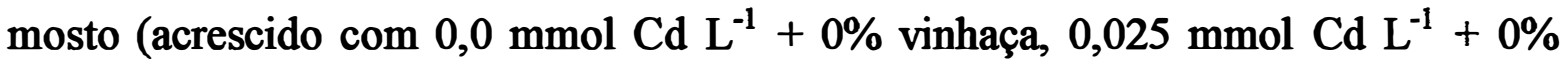

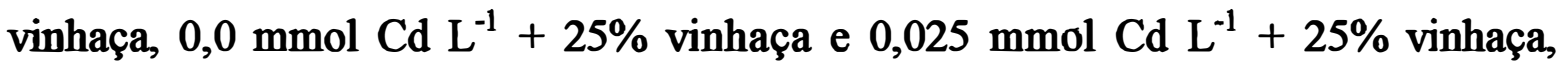
conforme o tratamento) e as fermentações conduzidas à $33-34^{\circ} \mathrm{C}$, sendo os tubos tapados com folha de alumínio para se evitar perdas, por evaporação, de etanol e água. Ao final de cada fermentação, cuja velocidade foi estimada pela perda de peso $\left(\mathrm{CO}_{2}\right)$ a cada hora, o fermento foi separado mediante centrifugação a $800 \mathrm{G}$, pesado e reutilizado numa fermentação subsequente, sempre precedida do tratamento ácido, compreendendo 6 ciclos fermentativos.

\subsubsection{Taxa de viabilidade, taxa de brotamento e contaminação bacteriana}

No final de cada dia, foram retirados $0,5 \mathrm{~mL}$ de cada suspensão, sendo a taxa de viabilidade, taxa de brotamento e contaminação bacteriana determinadas conforme item 3.1.1.7. 


\subsubsection{Análise do etanol}

Ao final de cada ciclo fermentativo, o etanol foi dosado como descrito no item 3.1.1.8.

3.4.1.10 Análise do glicerol e de açúcares residuais (sacarose, glicose e frutose) no vinho

Ao final de cada ciclo fermentativo, o glicerol e os açúcares residuais foram dosados conforme descrito no item 3.3.1.9.

\subsubsection{Densidades dos vinhos delevurados}

Ao final de cada ciclo fermentativo, a desidade dos vinhos delevurados foi determinada conforme descrito no item 3.3.1.10.

\subsubsection{2 pH dos vinhos delevurados}

Ao final de cada ciclo fermentativo, o $\mathrm{pH}$ dos vinhos delevurados foi estimado diretamente em potenciômetro digital (Digimed, modelo DPH2).

\subsubsection{Análise de glicogênio}

Ao final do sexto ciclo fermentativo, o glicogênio foi extraído e dosado conforme descrito no item 3.3.1.12. 
3.4.1.14 Análise de trealose

Ao final do sexto ciclo fermentativo, a trealose foi extraída e mensurada conforme descrito no item 3.1.1.9.

\subsubsection{Análise de nitrogênio}

Da biomassa seca foi quantificado o nitrogênio total, conforme descrito no item 3.3.1.14.

\subsubsection{Cálculo do rendimento fermentativo}

O rendimento fermentativo foi calculado conforme descrito no item

\subsubsection{5.}

\subsubsection{Análise estatística}

A análise de variância (teste de F) foi utilizada para analisar as variáveis, seguida de uma análise sob esquema parcelas subdivididas no tempo em delineamento em blocos ao acaso, com classificação cruzada e 3 repetições. As comparações de médias foram feitas pelo teste de comparações múltiplas de Tukey (Snedecor \& Cochran, 1967). Os resultados da análise estatística podem ser observados no Anexo 22. 


\subsection{Ensaio 5}

\subsubsection{Procedimento experimental}

\subsubsection{Preparo da vidraria}

Toda a vidraria reutilizável foi previamente preparada conforme descrito no item 3.1.1.1.

\subsubsection{Preparo das soluções}

Todas as soluções utilizadas foram preparadas conforme descrito no item 3.1.1.2.

\subsubsection{Obtenção da vinhaça}

A vinhaça foi obtida conforme descrito no item 3.2.1.1.

\subsubsection{Preparo do caldo de cana}

O caldo de cana foi preparado conforme descrito no item 3.4.1.4., apresentando $19,56 \%$ de ART final.

\subsubsection{Cepa utilizada}

Utilizou-se a levedura Saccharomyces cerevisiae PE-2, caracterizada pelo método de cariotipagem (Basso et al., 1993), e oriunda da Coleção de Leveduras do Departamento de Ciências Biológicas (ESALQ/USP). 


\subsubsection{Pré-crescimento da levedura}

Partindo de uma cultura pura (liofilizada), a levedura foi reativada conforme descrito no item 3.1.1.4.

\subsubsection{Ensaio de fermentação}

As fermentações foram conduzidas em tubos de centrífuga de vidro com 150 $\mathrm{mL}$ de capacidade, contendo uma quantidade inicial de levedura de 8,00 g (massa úmida). A massa de levedura foi suspensa em $20 \mathrm{~mL}$ de água destilada esterilizada (ou vinhaça, de acordo com o tratamento), submetida à uma acidificação com $\mathrm{H}_{2} \mathrm{SO}_{4}$ até $\mathrm{pH}=2,5$ e mantida em repouso por 1 hora, tentando imitar o tratamento ácido conduzido no processo industrial. Em seguida foram adicionados $60 \mathrm{~mL}$ de mosto (acrescido com 0,0 mmol Cd $\mathrm{L}^{-1}+0 \%$ vinhaça, 0,025 mmol Cd $\mathrm{L}^{-1}+0 \%$ vinhaça, $0,05 \mathrm{mmol} \mathrm{Cd} \mathrm{L}^{-1}+0 \%$ vinhaça, $0,025 \mathrm{mmol} \mathrm{Cd} \mathrm{L}^{-1}+25 \%$ vinhaça e $0,05 \mathrm{mmol} \mathrm{Cd} \mathrm{L}^{-1}+25 \%$ vinhaça conforme o tratamento) e as fermentações conduzidas à $33-34^{\circ} \mathrm{C}$, sendo os tubos tapados com folha de alumínio para se evitar perdas, por evaporação, de etanol e água. Ao final de cada fermentação, cuja velocidade foi estimada pela perda de peso $\left(\mathrm{CO}_{2}\right)$ a cada hora, o fermento foi separado mediante centrifugação a $800 \mathrm{G}$, pesado e reutilizado numa fermentação subsequente, sempre precedida do tratamento ácido, compreendendo 6 ciclos fermentativos. 
3.5.1.8 Taxa de viabilidade, taxa de brotamento e contaminação bacteriana

No final de cada dia, foram retirados $0,5 \mathrm{~mL}$ de cada suspensão, sendo a taxa de viabilidade, taxa de brotamento e contaminação bacteriana determinadas conforme item 3.1.1.7.

\subsubsection{Análise de trealose}

Ao final do sexto ciclo fermentativo, a trealose foi extraída e mensurada conforme descrito no item 3.1.1.9.

\subsubsection{Observação da integridade da parede celular}

A integridade da parede celular das células foi observada ao microscópio eletrônico de varredura e pressão variável LEO435VP. As células foram primeiramente tratadas com fixador de Kamovsky modificado (Kitajima, 1997), sendo a seguir fixadas com tetróxido de ósmio seguindo-se desidratação com cetona e secagem ao ponto crítico. Após a montagem dos stubs foi feita metalização com ouro.

\subsubsection{Determinação do acúmulo de cádmio:}

Após a secagem, 1,00g de levedura foi submetida à digestão sufo-nitroperclórica $\left(\mathrm{H}_{2} \mathrm{SO}_{4} ; \mathrm{HNO}_{3} ; \mathrm{HClO}_{4}\right.$ na proporção de 2:5:3) segundo a metodologia proposta por Varma (1986). As amostras de biomassa foram colocadas em tubos de boro silicato de $20 \times 250$ e aquecidas à $150^{\circ} \mathrm{C}$ por 5 horas até a total descoloração, 
quando o material foi considerado mineralizado. As amostras foram então diluídas a $25 \mathrm{~mL}$ em balão volumétrico e submetidas à análise por espectrometria de absorção atômica com atomização eletrotérmica em forno de grafite.

\subsubsection{Análise estatística}

A análise de variância (teste de F) foi utilizada para analisar as variáveis, seguida de uma análise sob esquema parcelas subdivididas no tempo em delineamento em blocos ao acaso, com classificação cruzada e 3 repetições. As comparações de médias foram feitas pelo teste de comparações múltiplas de Tukey (Snedecor \& Cochran, 1967). Os resultados da análise estatística podem ser observados no anexo 25 . 


\section{RESUlTAdOS E DISCUSSÃo}

\subsection{Ensaio 1}

Conforme pode ser observado nas Figuras 2 e 3, o cádmio foi tóxico para ambas as leveduras em todas as concentrações testadas. Além do menor crescimento, pode ser observado o atraso da fase Log, provocado por $0,05 \mathrm{mmol}$ $\mathrm{L}^{-1}$ do metal. A cepa PE-2 apresentou maior tolerância ao metal que a cepa IZ1904, o que pode ser observado quanto confrontamos os resultados obtidos para ambas as cepas com 0,05 e 0,10 $\mathrm{mmol} \mathrm{L}^{-1}$ de cádmio. 


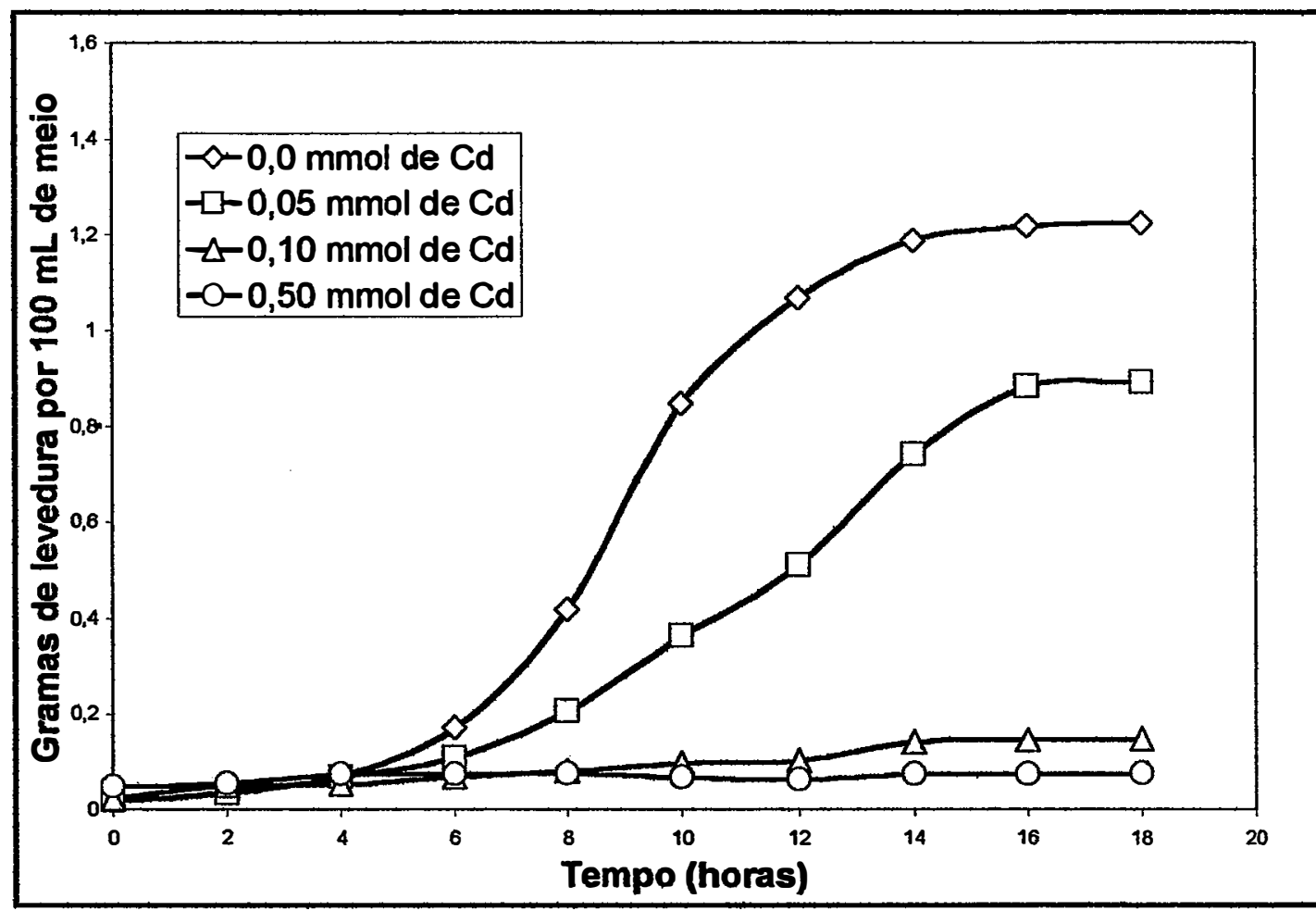

Figura 2-Crescimento da levedura IZ-1904 em meios com diferentes concentrações crescentes de cádmio.

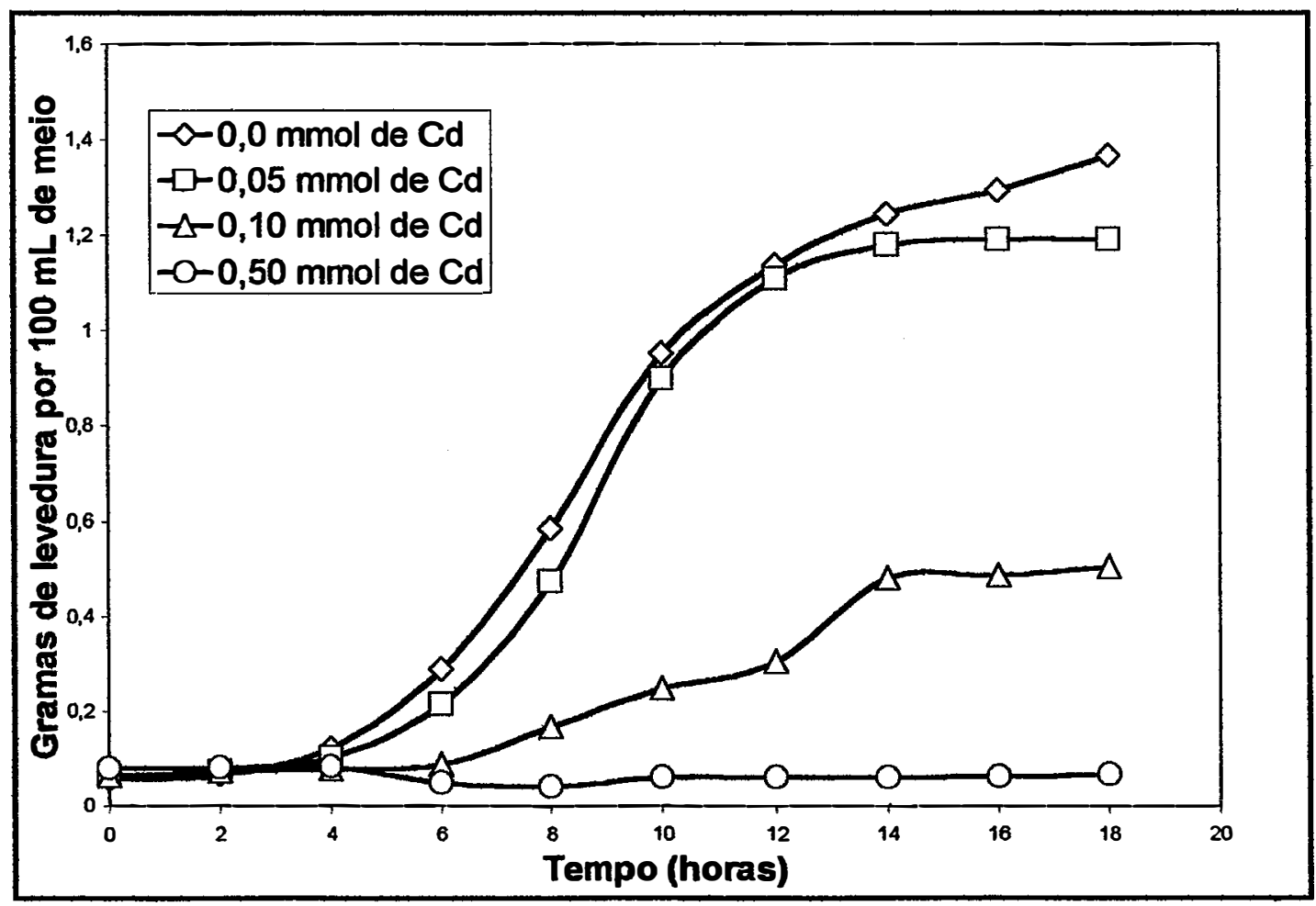

Figura 3 - Crescimento da levedura PE-2 em meios com diferentes concentrações de cádmio. 
No Anexo 3 encontram- se os valores de peso de fermento (g 100 $\mathrm{mL}^{-1}$ ) que deram origem aos gráficos apresentados nas Figuras 2 e 3.

Nas Tabelas 5, 6 e 7 podem ser observados os resultados das determinações de taxa de viabilidade, taxa de brotamento e produção de álcool. Não foi constatada contaminação bacteriana significante em nenhum dos tratamentos.

Tabela 5: Taxa de viabilidade (\%) e taxa de brotamento (\%) no final dos ensaios (18 horas).

\begin{tabular}{ccccc}
\hline \multirow{2}{*}{ Ensaio } & \multicolumn{2}{c}{ IZ-1904 } & \multicolumn{2}{c}{ PE-2 } \\
& $\begin{array}{c}\text { viabilidade } \\
(\%)\end{array}$ & $\begin{array}{c}\text { brotamento } \\
(\%)\end{array}$ & $\begin{array}{c}\text { viabilidade } \\
(\%)\end{array}$ & $\begin{array}{c}\text { brotamento } \\
(\%)\end{array}$ \\
\hline Inicial & 98,32 & 9,22 & 99,18 & 9,05 \\
$0,00 \mathrm{mmol} \mathrm{L}^{-1} \mathbf{C d}$ & 87,73 & 13,18 & 94,74 & 29,78 \\
$0,05 \mathrm{mmol} \mathrm{L}^{-1} \mathbf{C d}$ & 80,03 & 12,95 & 86,66 & 15,70 \\
$0,1 \mathrm{mmol} \mathrm{L}^{-1} \mathbf{C d}$ & 65,72 & 11,06 & 59,86 & 19,12 \\
$0,5 \mathrm{mmol} \mathrm{L}^{-1} \mathrm{Cd}$ & 89,80 & 1,60 & 86,32 & 11,46 \\
\hline
\end{tabular}

Tabela 6: Trealose (g $\left.100 \mathrm{~g}^{-1}\right)$, mensurada no início e no final dos ensaios (18 horas) para cada levedura.

\begin{tabular}{ccc}
\hline Ensaio & $\begin{array}{c}\text { IZ-1904 } \\
\text { trealose }(\% \mathrm{MS})\end{array}$ & $\begin{array}{c}\text { PE-2 } \\
\text { trealose }(\% \mathrm{MS})\end{array}$ \\
\hline Inicial & 2,50 & 3,56 \\
$0,00 \mathrm{mmol} \mathrm{L}^{-1} \mathrm{Cd}$ & 2,31 & 3,63 \\
$0,05 \mathrm{mmol} \mathrm{L}^{-1} \mathrm{Cd}$ & 0,50 & 0,17 \\
$0,1 \mathrm{mmol} \mathrm{L}^{-1} \mathrm{Cd}$ & 0,56 & 0,20 \\
$0,5 \mathrm{mmol} \mathrm{L}^{-1} \mathrm{Cd}$ & 1,59 & 1,31 \\
\hline
\end{tabular}

Tabela 7: Álcool (\% v/v), mensurada no início e no final dos ensaios (18 horas) para cada levedura.

\begin{tabular}{ccc}
\hline Ensaio & IZ-1904 & PE-2 \\
\hline $0,00 \mathrm{mmol} \mathrm{L}^{-1} \mathrm{Cd}$ & 1,00 & 1,03 \\
$0,05 \mathrm{mmol} \mathrm{L}^{-1} \mathrm{Cd}$ & 0,88 & 0,98 \\
$0,1 \mathrm{mmol} \mathrm{L}^{-1} \mathrm{Cd}$ & 0,45 & 0,69 \\
$0,5 \mathrm{mmol} \mathrm{L}^{-1} \mathrm{Cd}$ & 0,00 & 0,00 \\
\hline
\end{tabular}


O atraso na fase Log foi acompanhado de uma discreta diminuição da taxa de viabilidade (Tabela 5) e concomitante diminuição do teor de trealose (Tabela 6). Nesta ocasião, a levedura PE-2 apresentou maior taxa de viabilidade e teor de trealose.

Os teores de trealose nas leveduras decresceram com o aumento das doses de cádmio e consequente queda na viabilidade. A trealose é um dissacarídeo não redutor constituído de duas unidades de glicose, e parece exercer um efeito protetor sobre as células de levedura durante processos de estresse (Gutierrez, 1994). O modelo mais aceito para explicar o efeito protetor da trealose é o proposto por Crowe et al., (1984). Segundo os autores, a trealose interage com os gnupos polares das cadeias fosfolipídicas existentes na membrana, substituindo a água que está ligada às cabeças polares dos fosfolipídios quando em condições favoráveis e seria perdida no processo de estresse. Com a ligação da trealose à membrana não há alteração do espaçamento entre os fosfolipídios, evitando assim as separações laterais dos componentes da membrana. Com a substituição das moléculas de água pela trealose, mantém-se a integridade e a fluidez da membrana, e assim, a viabilidade celular.

Grafl \& Schwantes (1983a) também notaram atraso na fase Log trabalhando com Saccharomyces cerevisiae. Porém, eles relatam que a toxidade para cádmio começou a se manifestar na concentração de $0,001 \mathrm{mmol} \mathrm{L}^{-1}$, e que $0,1 \mathrm{mmol} \mathrm{L} \mathrm{L}^{-1}$ impediu a divisão celular completamente. Quando comparamos a 
toxicidade do cádmio para a cepa PE-2, IZ-1904 e a utilizada pelos autores, podemos observar que a cepa PE-2 é claramente mais resistente ao cádmio.

Enquanto $0,10 \mathrm{mmol} \mathrm{L}^{-1}$ inibiu totalmente o crescimento da levedura IZ1904, a levedura PE-2 ainda apresentou um significante crescimento ao final das 18 horas $\left(0,5 \mathrm{~g} 100 \mathrm{~mL}^{-1}\right)$. Esta maior resistência ao cádmio demonstrada pela levedura PE-2, quando comparada com a levedura IZ-1904 e a cepa utilizada por Grafl \& Schwantes (1983a) é particularmente interessante, visto que outros trabalhos (Basso \& Amorin, 1995; Basso \& Amorin, 1996) já haviam demonstrado a maior tolerância da levedura PE-2 à diversos fatores estressantes, tais como etanol, temperatura, sorbitol, tendo apresentado melhores médias de viabilidade, crescimento e rendimento fermentativo, quando comparada a outras leveduras.

A concentração de $0,50 \mathrm{mmol} \mathrm{L}^{-1}$ de cádmio inibiu totalmente o crescimento de ambas as leveduras, podendo ser observado um efeito interessante: apesar de não haver crescimento, as duas cepas apresentaram uma taxa de viabilidade maior que aquela apresentada para 0,1 e $0,05 \mathrm{mmol} \mathrm{L}^{-1}$ de cádmio (Tabela 5). Também houve um aumento dos teores de trealose no tratamento com $0,5 \mathrm{mmol} \mathrm{L}^{-1}$ de cádmio, significante em relação aos tratamentos com 0,05 e $0,1 \mathrm{mmol} \mathrm{L}^{-1}$ de cádmio (Tabela 06).

O cádmio é conhecido por interagir com os polifosfatos da membrana plasmática da levedura (Nakamura, 1965; Stevenink \& Booij 1964; Stevenink 
1966). Como estes polifosfatos atuam no transporte de glicose para dentro da célula (Brock et al, 1994; Griffin, 1994; Smith and Wood, 1996; Tijssen, 1981), este transporte deve ter sido completamente inibido nesta concentração de cádmio $\left(0,5 \mathrm{mmol} \mathrm{L}^{-1}\right)$. Provavelmente as leveduras se encontram em um estado de semiletargia, não sendo capazes de metabolizar a glicose do meio de fermentação, utilizando para sobreviver as suas reservas endôgenas (nitrogênio, trealose e glicogênio). Quando do esgotamento destas reservas, ocorrerá a morte destas células.

O aumento das concentrações de cádmio coincidiu com a diminuição na produção de álcool (Tabela 7). Provavelmente, com a diminuição da absorção de glicose, a glicólise foi prejudicada, ocorrendo diminuição no metabólito final desta via metabólica.

\subsection{Ensaio 2}

Como pode ser observado nas Figuras 4, 5 e 6, apesar de apresentar um discreto efeito tóxico, a vinhaça exerceu um forte efeito protetor sobre as leveduras quando o meio foi acrescido de cádmio. 


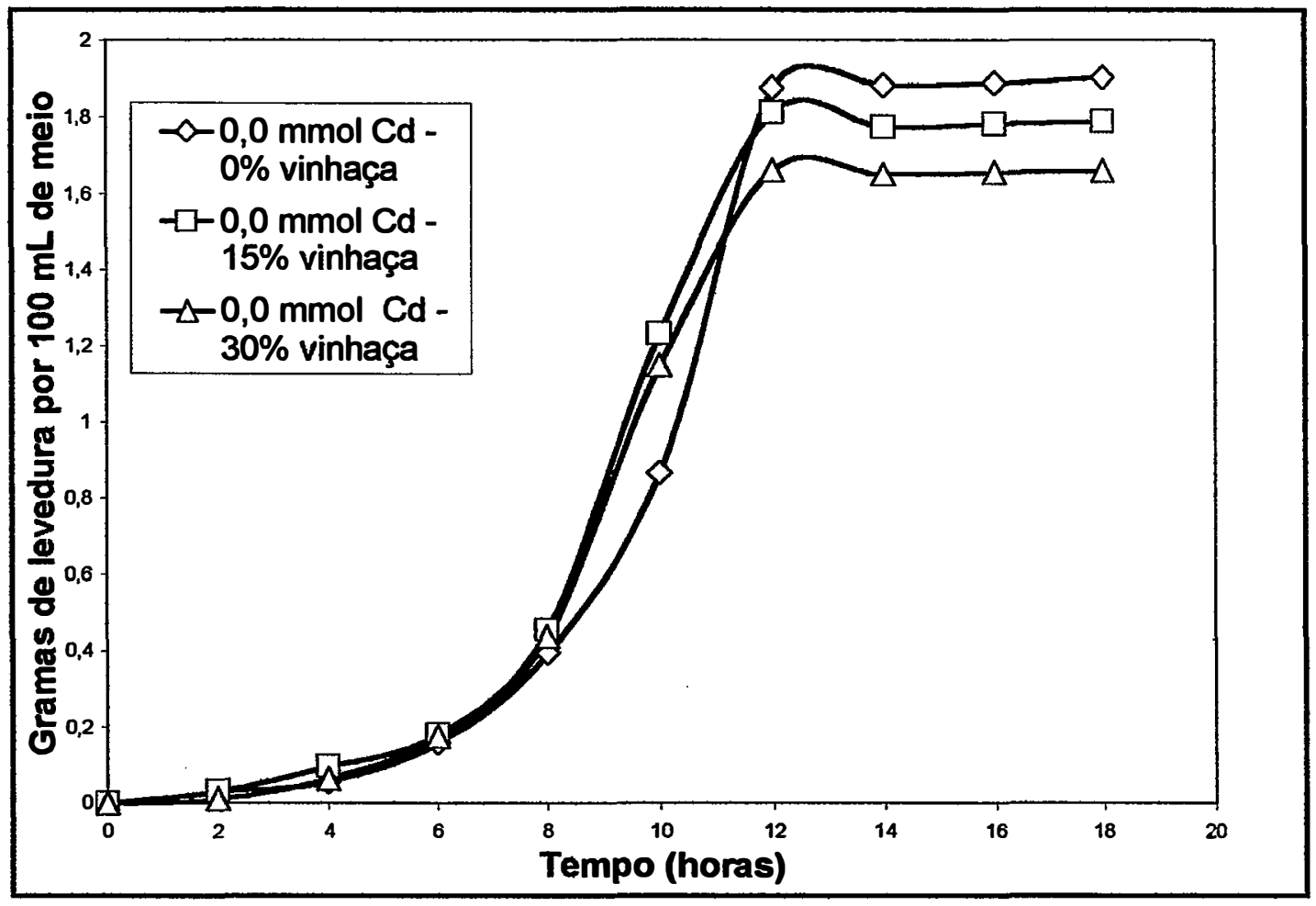

Figura 4 - Crescimento da levedura PE-2 em presença de vinhaça no meio (0, 15 e 30\%).

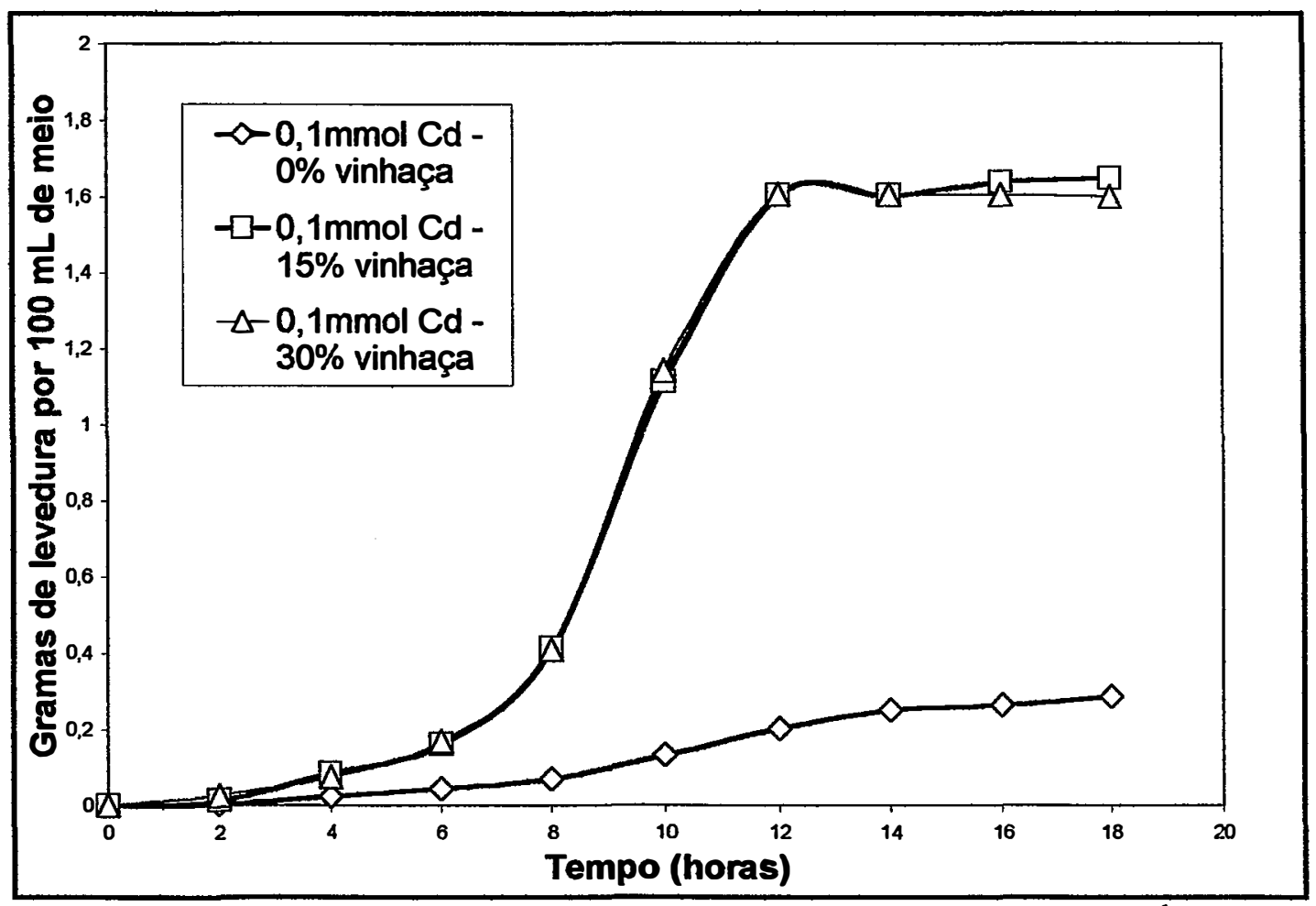

Figura 5 - Crescimento da levedura PE-2 em meio com cádmio $\left(0,1 \mathrm{mmol} \mathrm{L}^{-1}\right)$ e diferentes concentrações de vinhaça $(0,15$ e $30 \%)$. 


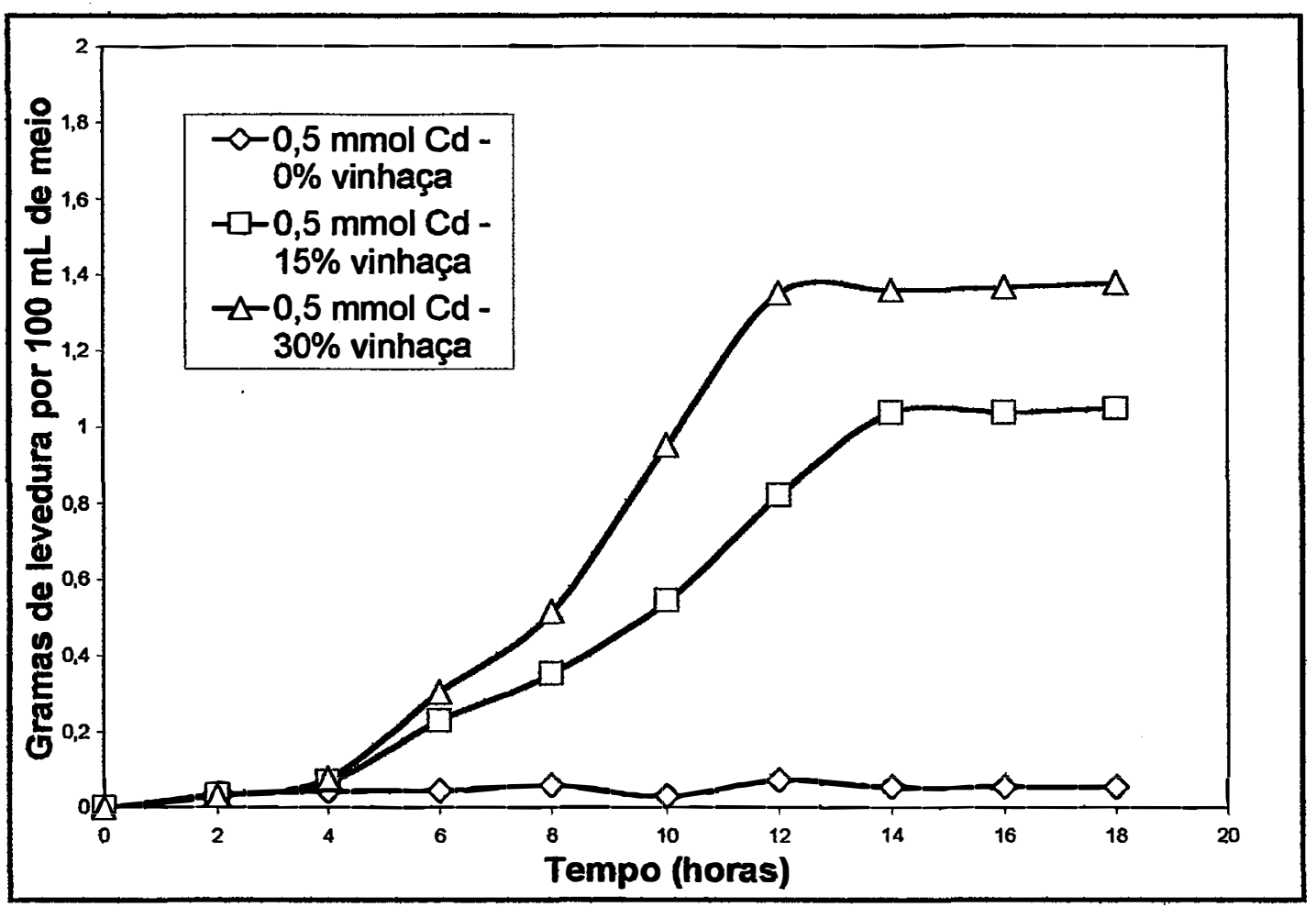

Figura 6 - Crescimento da levedura PE-2 em meio com cádmio $\left(0,5 \mathrm{mmol} \mathrm{L}^{-1}\right) \mathrm{e}$ diferentes concentrações de vinhaça $(0,15$ e $30 \%)$.

No Anexo 7 encontram-se os valores de peso de fermento (g $100 \mathrm{~mL}^{-1}$ ) que deram origem aos gráficos apresentados nas Figuras 4, 5 e 6.

Nas Tabelas 8, 9 e 10 podem ser observados os resultados das determinações da taxa de viabilidade, taxa de brotamento, teor de trealose e produção de álcool. Não foi constatada contaminação bacteriana significante em nenhum dos tratamentos. 
Tabela 8: Taxa de viabilidade (\%) e taxa de brotamento ao final dos ensaios (18 horas).

\begin{tabular}{|c|c|c|c|c|c|c|}
\hline \multirow[b]{2}{*}{ Ensaio } & \multicolumn{2}{|c|}{$0 \%$ vinhaça } & \multicolumn{2}{|c|}{$15 \%$ vinhaça } & \multicolumn{2}{|c|}{$30 \%$ vinhaça } \\
\hline & $\begin{array}{l}\text { viabilidade } \\
\text { (\%) }\end{array}$ & $\begin{array}{l}\text { brotamento } \\
\text { (\%) }\end{array}$ & $\begin{array}{l}\text { viabilidade } \\
\text { (\%) }\end{array}$ & $\begin{array}{l}\text { Brotamento } \\
\text { (\%) }\end{array}$ & $\begin{array}{l}\text { viabilidade } \\
\text { (\%) }\end{array}$ & $\begin{array}{l}\text { brotamento } \\
\text { (\%) }\end{array}$ \\
\hline Inicial & 99,74 & 18,50 & $\overline{99,74}$ & 18,50 & 99,74 & 18,50 \\
\hline $0,0 \mathrm{mmol} \mathrm{L}^{-1} \mathrm{Cd}$ & 99,54 & 22,07 & 99,83 & 22,71 & 100,00 & 23,41 \\
\hline $0,1 \mathrm{mmol} \mathrm{L}^{-1} \mathrm{Cd}$ & 67,40 & 6,31 & 99,68 & 16,15 & 99,44 & 16,08 \\
\hline $0,5 \mathrm{mmol} \mathrm{L}^{-1} \mathrm{Cd}$ & 0,00 & 0,00 & 99,85 & 23,11 & 99,48 & 21.03 \\
\hline
\end{tabular}

Tabela 9: Trealose ( $\left.\mathrm{g} 100 \mathrm{~g}^{-1}\right)$, mensurada no início e no final dos ensaios (18 horas).

\begin{tabular}{cccc}
\hline & & trealose (\%MS) \\
Ensaio & $0 \%$ vinhaça & $15 \%$ vinhaça & $30 \%$ vinhaça \\
\hline Inicial & 1,41 & 1,41 & 1,41 \\
$0,0 \mathrm{mmol} \mathrm{L}^{-1} \mathrm{Cd}$ & 1,35 & 1,48 & 1,20 \\
$0,1 \mathrm{mmol} \mathrm{L}^{-1} \mathrm{Cd}$ & 0,05 & 0,11 & 0,52 \\
$0,5 \mathrm{mmol} \mathrm{L}^{-1} \mathrm{Cd}$ & 0,00 & 0,40 & 0,52 \\
\hline
\end{tabular}

Tabela 10: Álcool (\% v/v) no vinho no final dos ensaios (18 horas)

\begin{tabular}{|c|c|c|c|}
\hline \multirow[b]{2}{*}{ Ensaio } & \multicolumn{3}{|c|}{ \% álcool no vinho } \\
\hline & $0 \%$ vinhaça & $15 \%$ vinhaça & $30 \%$ vinhaça \\
\hline $0,0 \mathrm{mmol} \mathrm{L}^{-1} \mathrm{Cd}$ & 0,97 & 1,03 & 1,03 \\
\hline $0,1 \mathrm{mmol} \mathrm{L}^{-1} \mathrm{Cd}$ & 0,71 & 1,09 & 1,09 \\
\hline $0,5 \mathrm{mmol} \mathrm{L}^{-1} \mathrm{Cd}$ & 0,0 & 1,06 & 1,06 \\
\hline
\end{tabular}

No ensaio 2, foi possível observar um pequeno efeito depressivo sobre o crescimento provocado pela vinhaça (Figura 4), porém sem afetar a viabilidade celular (Tabela 8) ou o teor de trealose (Tabela 9). Apesar disto, ficou bem evidenciado o efeito protetor da vinhaça sobre a ação tóxica do cádmio avaliada pelos parâmetros crescimento (Figuras 5 e 6), conteúdo de trealose (Tabelas 9), viabilidade (Tabela 8).

Esta proteção proporcionada pela vinhaça pode ser atribuída às interações pouco conhecidas entre o cádmio e os compostos orgânicos e inorgânicos presentes em um meio complexo (Remacle, 1990). O cádmio, como já foi 
relatado por Ramamoorthy \& Kushner (1975), tem uma alta afinidade por compostos orgânicos, sendo a vinhaça conhecidamente rica em matéria orgânica (Silva \& Orlando-Filho, 1981). A ação individual de grupos orgânicos, quelantes e sequestradores, com ligações como $\mathrm{R}-\mathrm{S}^{-}, \mathrm{SO}_{4}{ }^{-2}, \mathrm{~F}^{-}, \mathrm{NO}_{3}^{-}, \mathrm{NH}_{3}$, etc, é desconhecida (Remacle, 1990), bem como as interações no ambiente fermentativo de um mosto YED-vinhaça ou caldo de cana-vinhaça; por outro lado, a vinhaça é conhecidamente rica em compostos minerais tais como cálcio, zinco, enxofre, etc. (Silva \& Orlando-Filho, 1981), que como foi demonstrado por vários autores (Assmann et al., 1996; Grafl \& Schwantes, 1983a; 1983b; Kessels et al., 1985; Norris \& Kelly, 1977) podem por competição ou complexação atenuar a toxidade do cádmio sobre a levedura.

Desta forma, uma possível explicação para o decréscimo da toxidade do cádmio quando a vinhaça foi adicionada ao meio de fermentação, seria que os compostos orgânicos e minerais presentes na vinhaça reagem com o cádmio formando compostos que são menos tóxicos que os ions livres.

\subsection{Ensaio 3}

Nas Figuras de 7 à 19 são apresentados os resultados obtidos para rendimento fermentativo, etanol, peso de fermento, taxa de viabilidade, taxa de brotamento, $\mathrm{pH}$ do vinho, glicerol no vinho, glicose residual, frutose residual, sacarose residual, trealose, glicogênio e nitrogênio. 


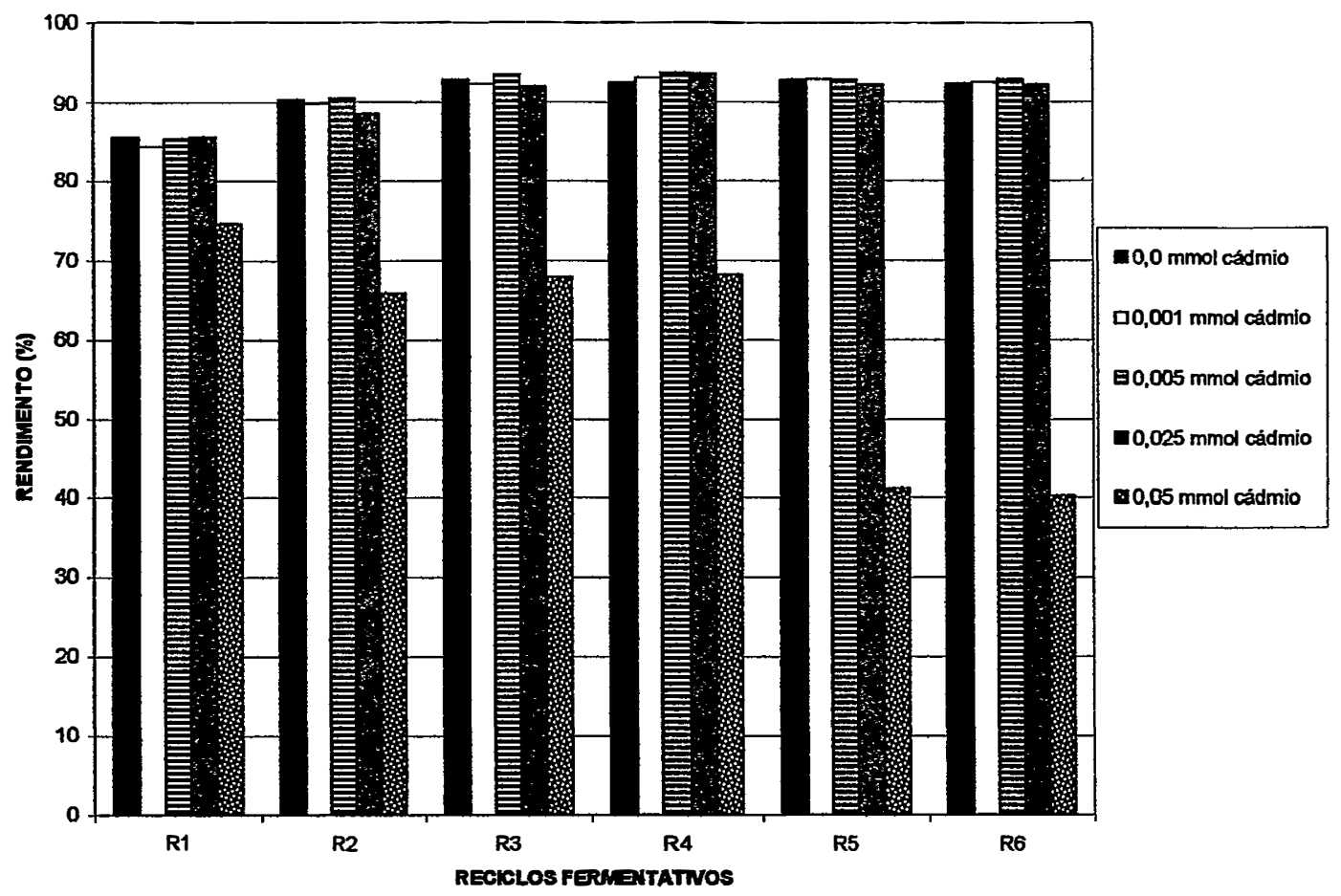

Figura 7 - Efeito de cinco concentrações de cádmio sobre o rendimento fermentativo (\%), no transcorrer de 6 reciclos fermentativos.

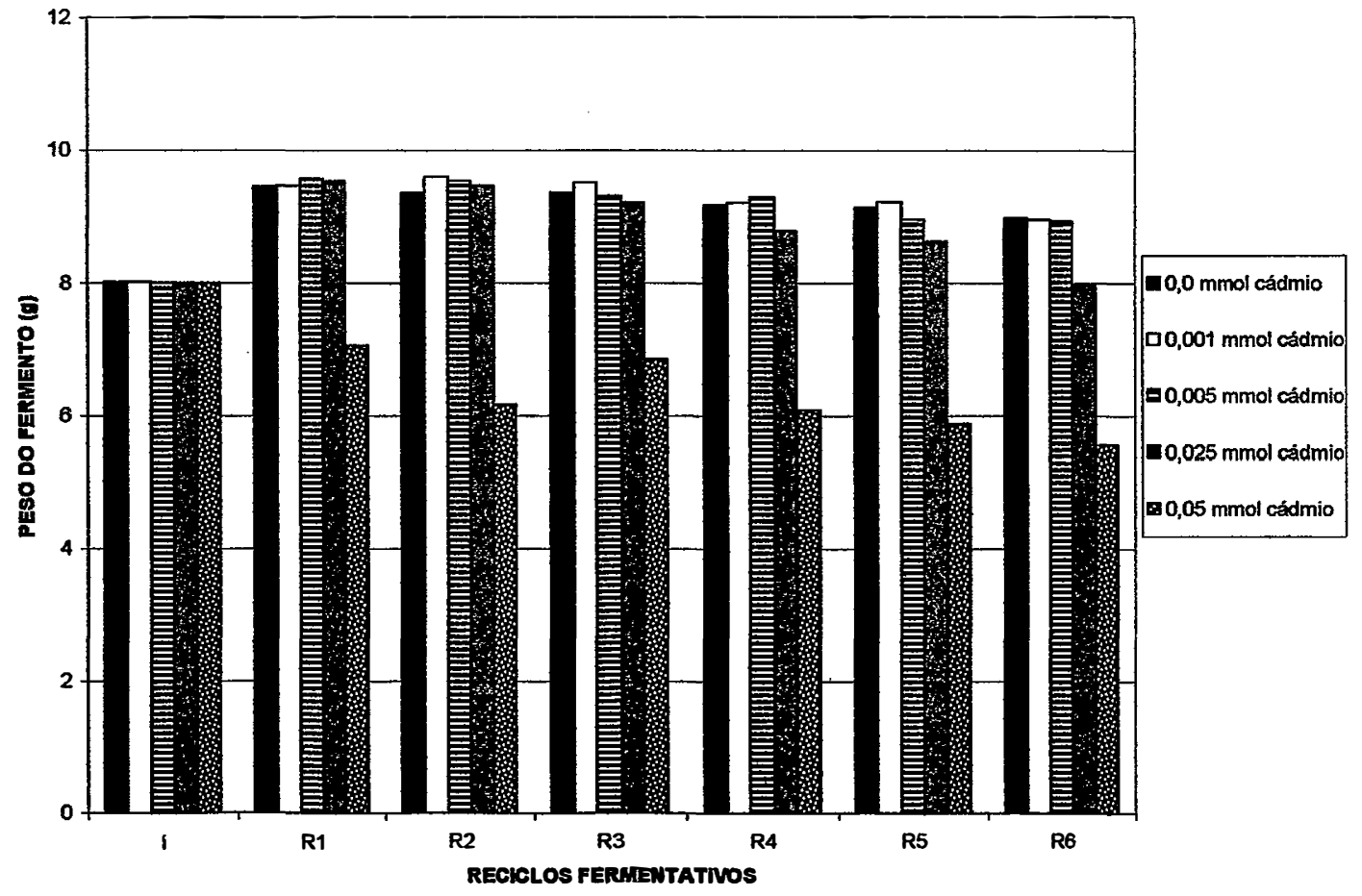

Figura 8 - Efeito de cinco concentrações de cádmio sobre o peso do fermento (g), no transcorrer de 6 reciclos fermentativos. 


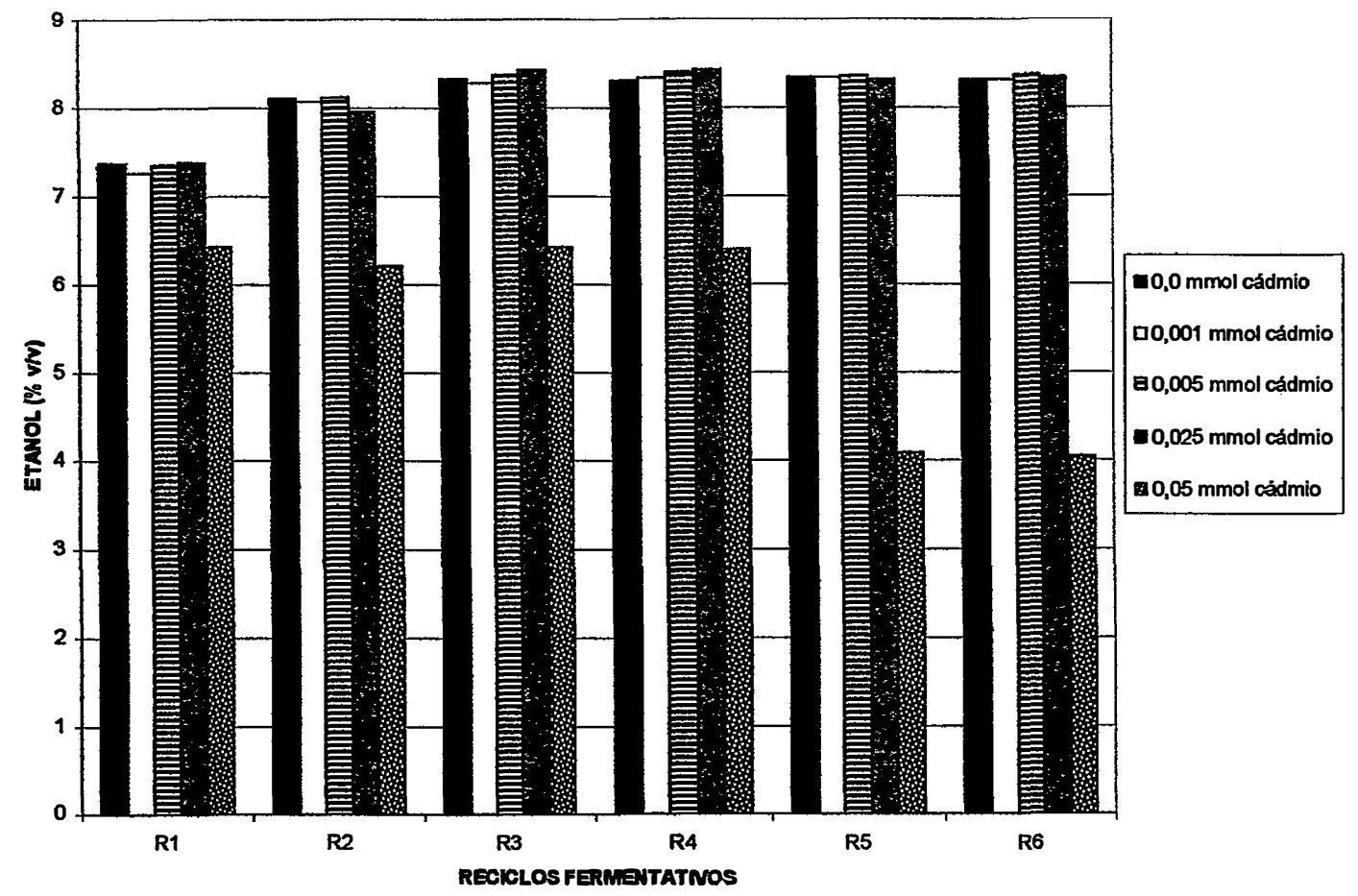

Figura 9 - Efeito de cinco concentrações de cádmio sobre a formação de etanol (\% v/v), no transcorrer de 6 reciclos fermentativos.

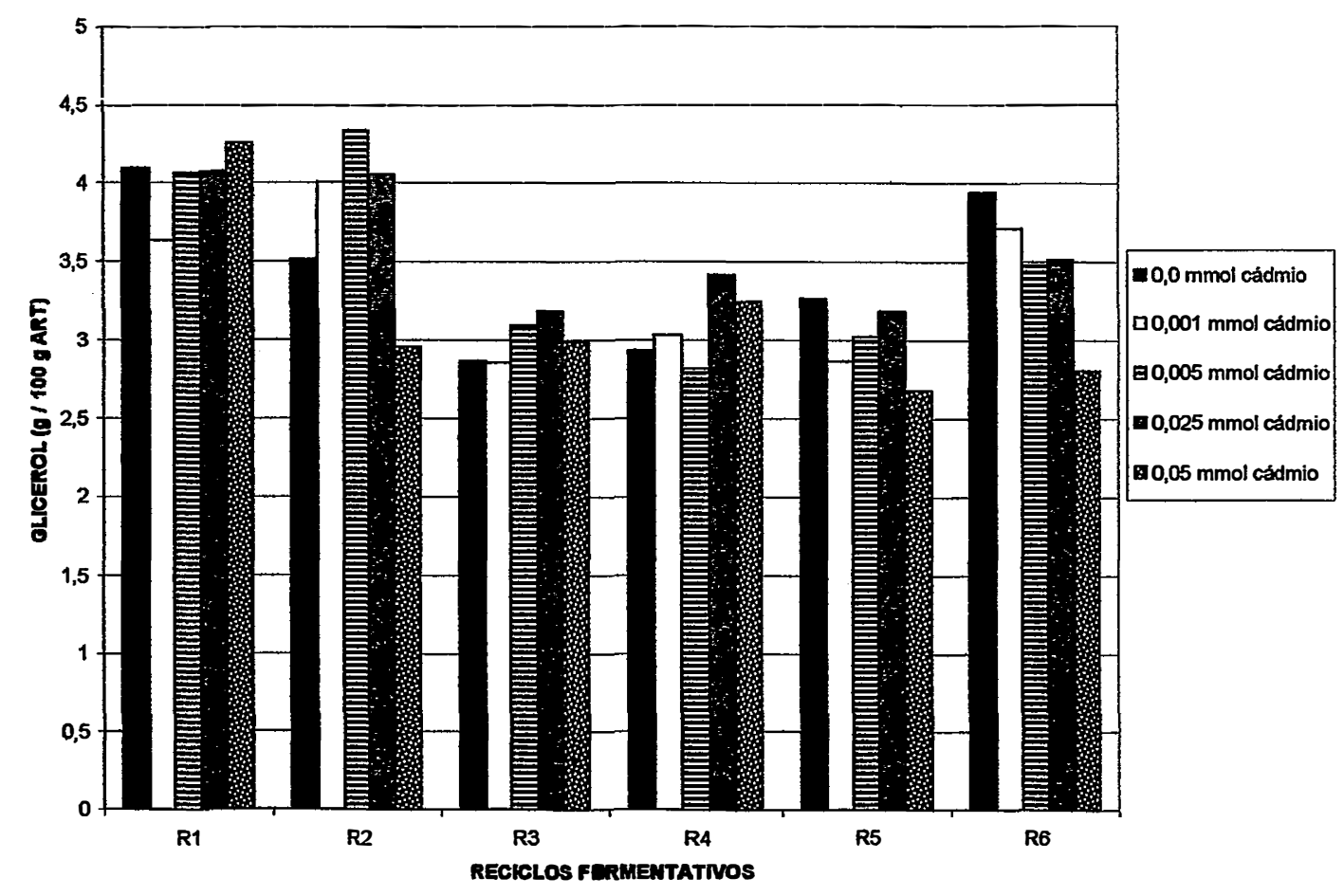

Figura 10 - Efeito de cinco concentrações de cádmio sobre a formação de glicerol (g / $100 \mathrm{~g}$ ART), no transcorrer de 6 reciclos fermentativos. 


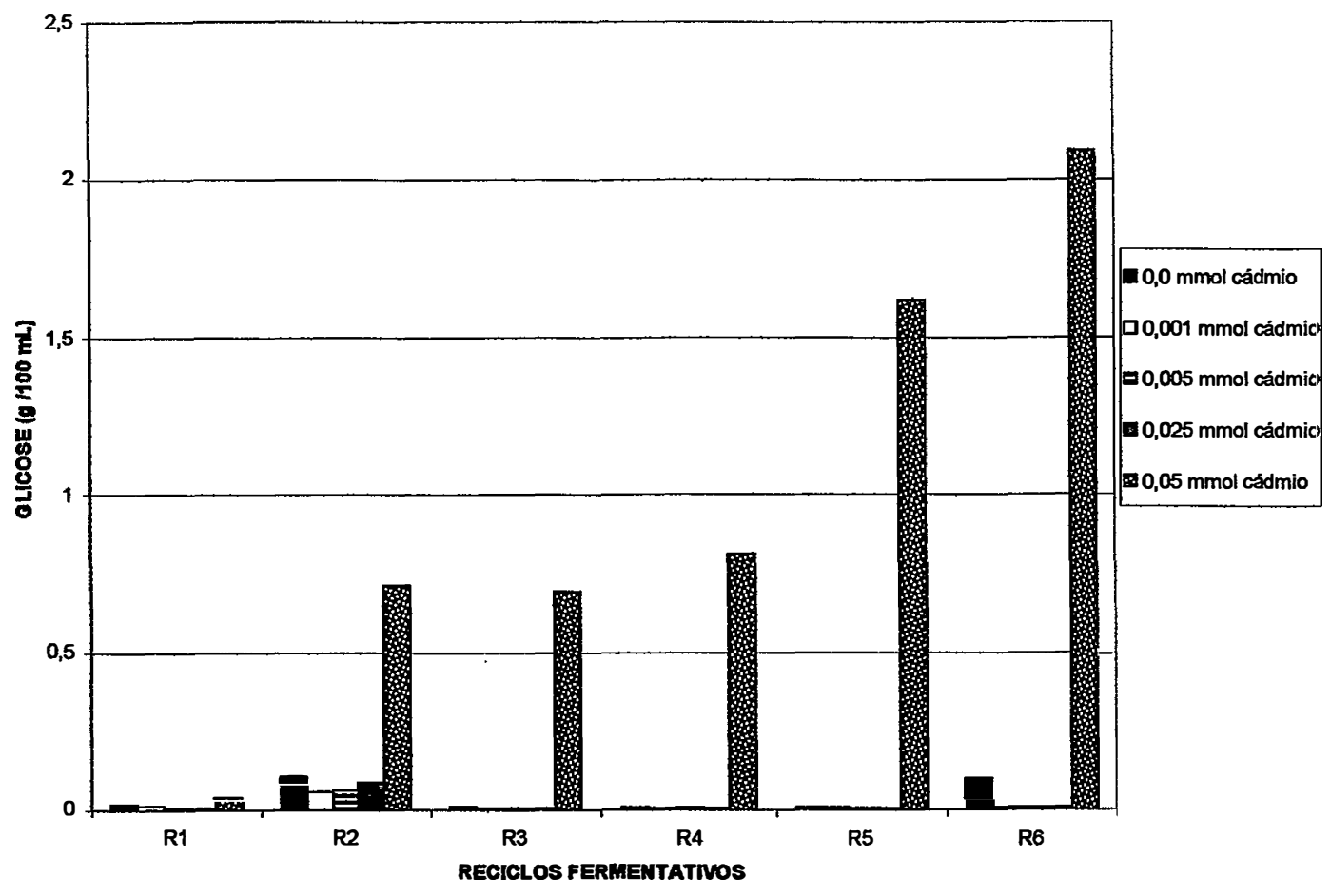

Figura 11 - Efeito de cinco concentrações de cádmio sobre a glicose residual no vinho $\left(\mathrm{g} 100 \mathrm{ml}^{-1}\right)$, no transcorrer de 6 reciclos fermentativos.

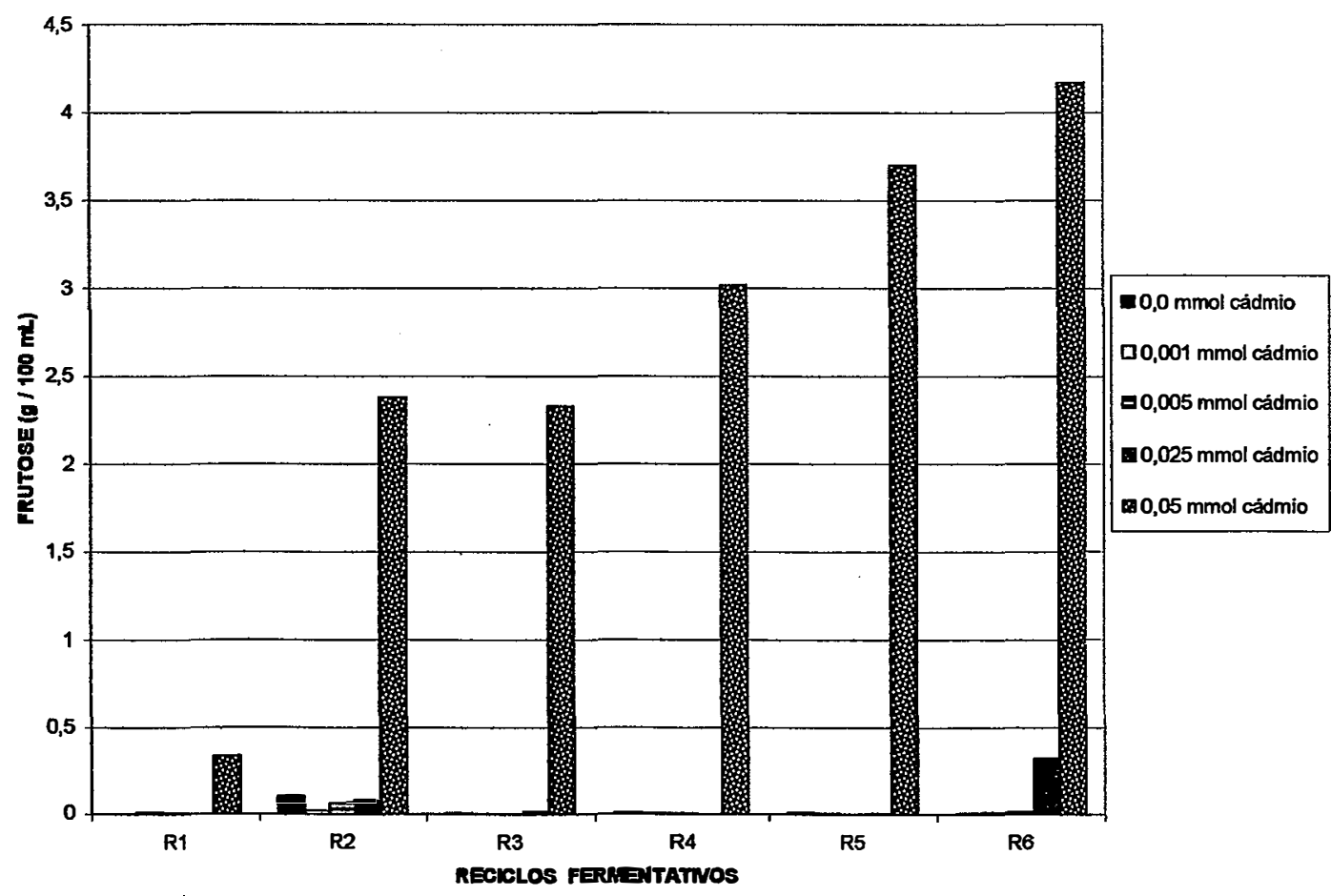

Figura 12 - Efeito de cinco concentrações de cádmio sobre a frutose residual no vinho $\left(\mathrm{g} 100 \mathrm{ml}^{-1}\right)$, no transcorrer de 6 reciclos fermentativos. 


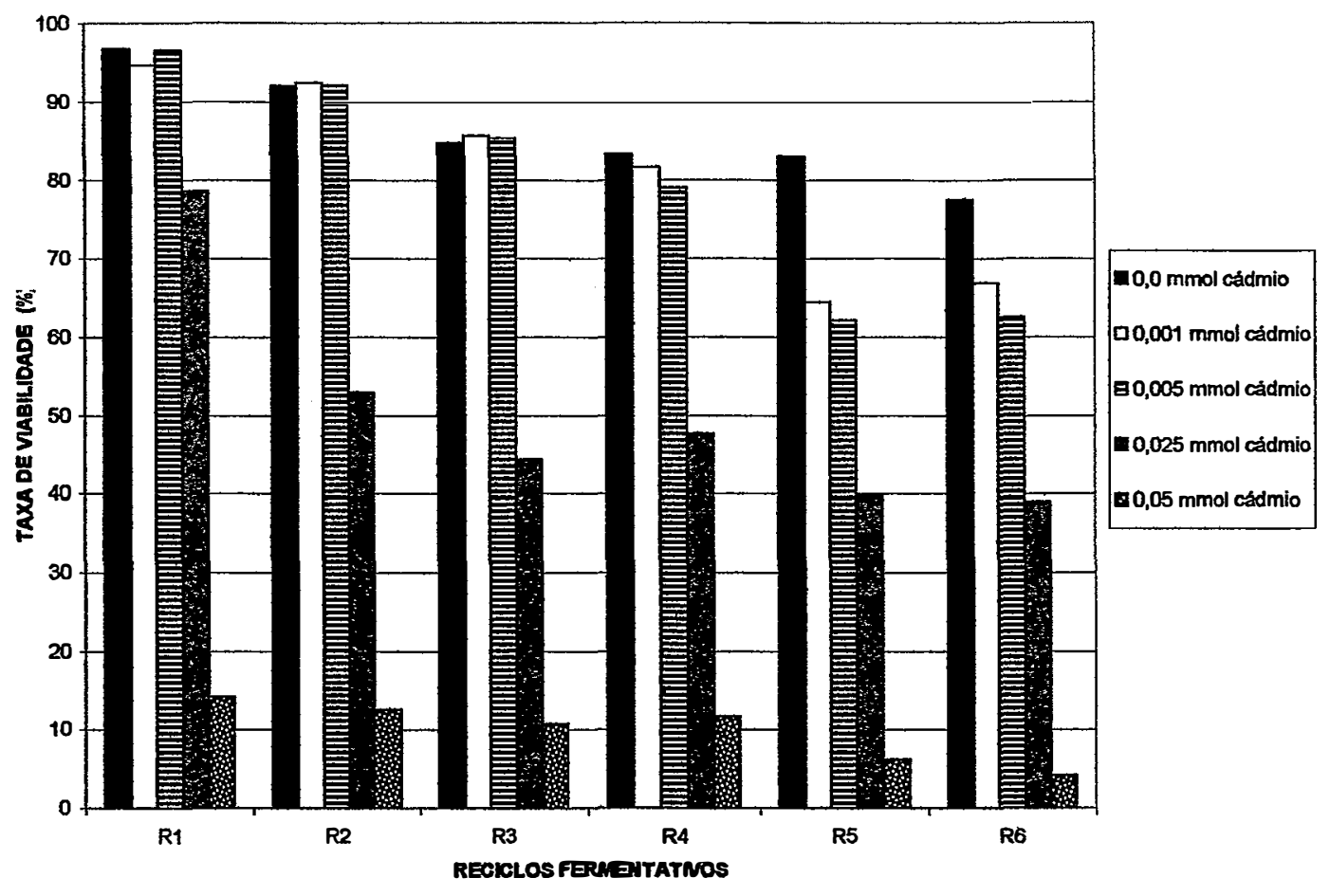

Figura 13 - Efeito de cinco concentrações de cádmio sobre a taxa de viabilidade do fermento (\%), no transcorrer de 6 reciclos fermentativos.

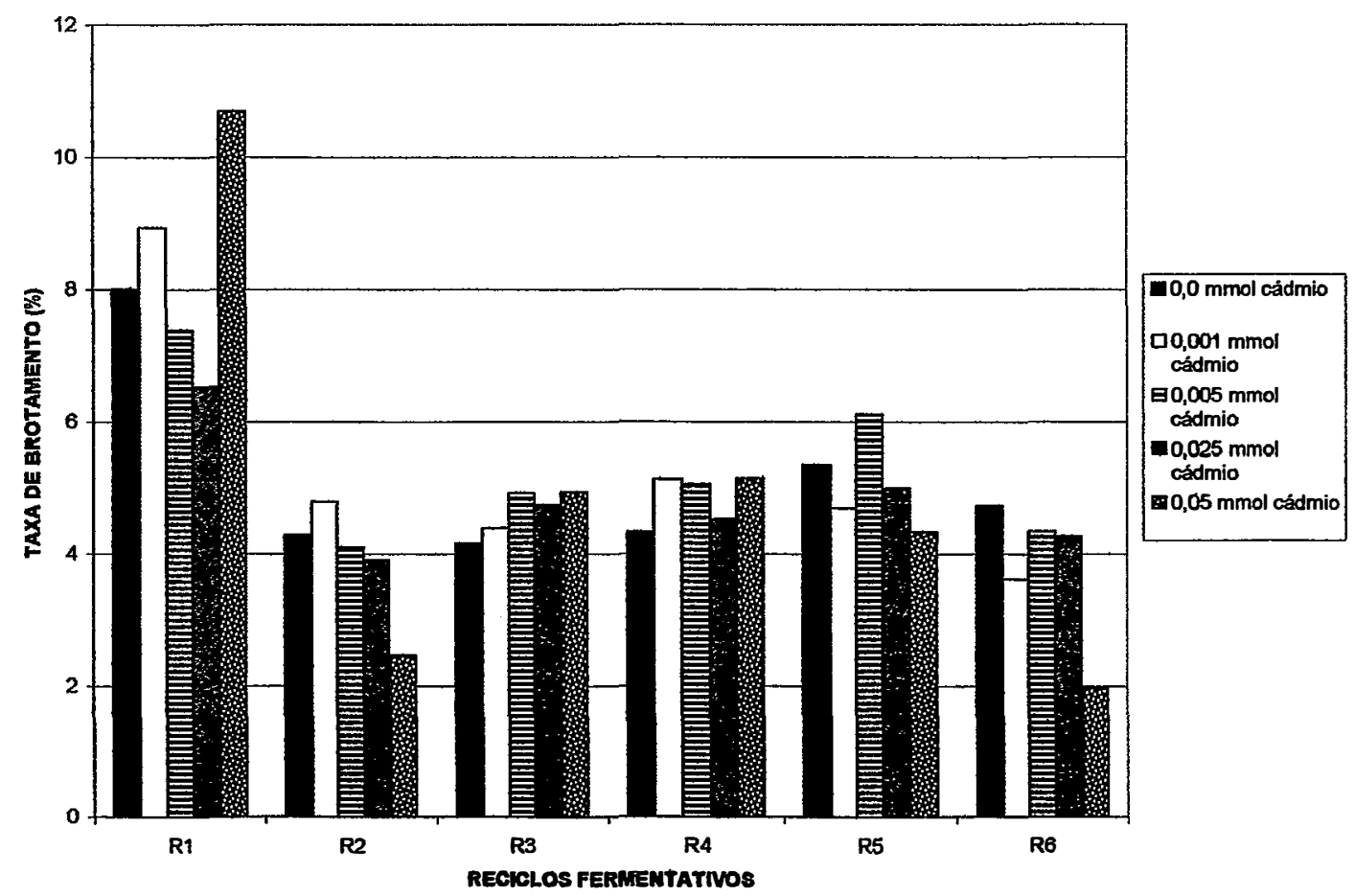

Figura 14 - Efeito de cinco concentrações de cádmio sobre a taxa de brotamento do fermento, no transcorrer de 6 reciclos fermentativos. 


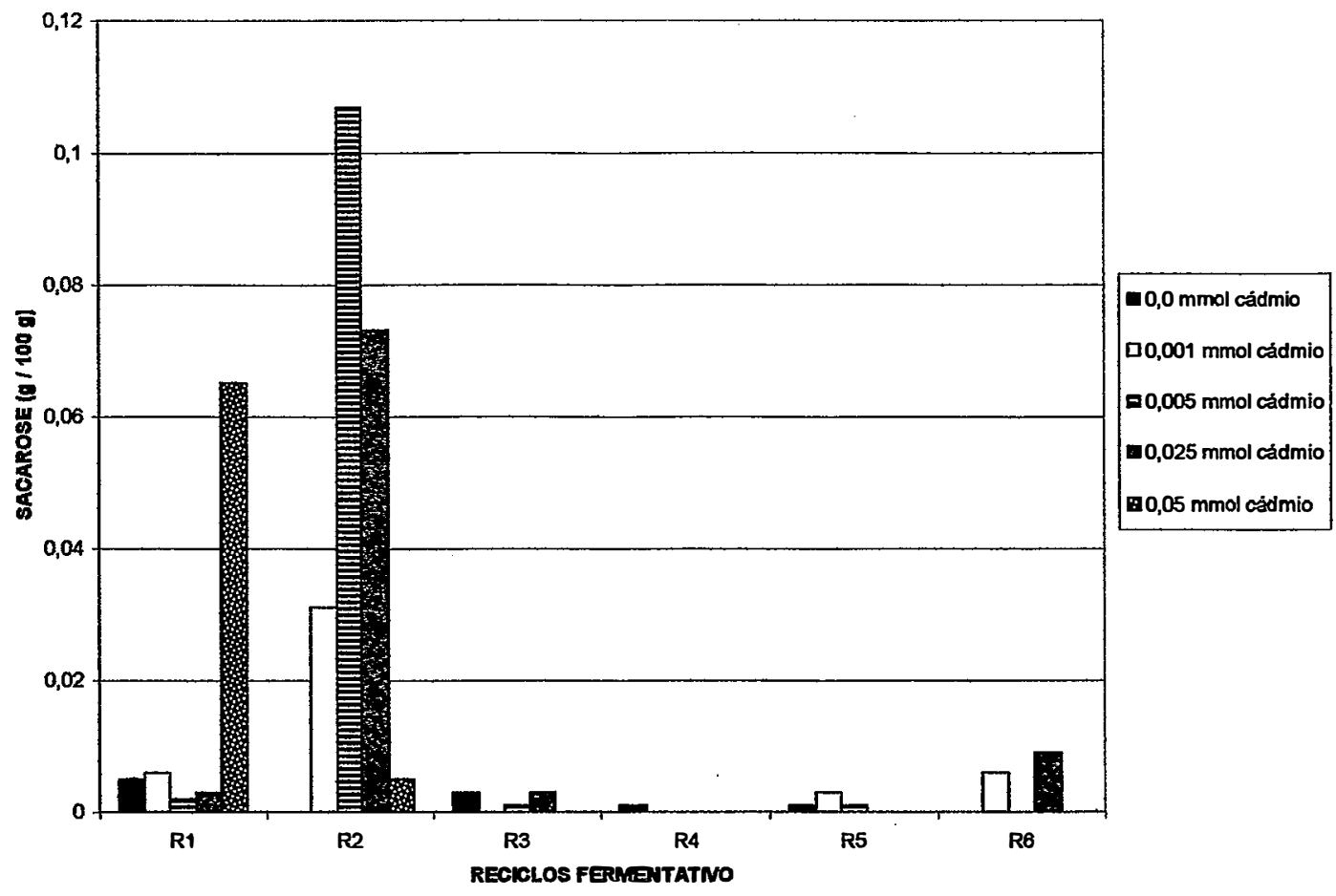

Figura 15 - Efeito de cinco concentrações de cádmio sobre a sacarose residual no vinho (g $100 \mathrm{~mL}^{-1}$ ), no transcorrer de 6 reciclos fermentativos.

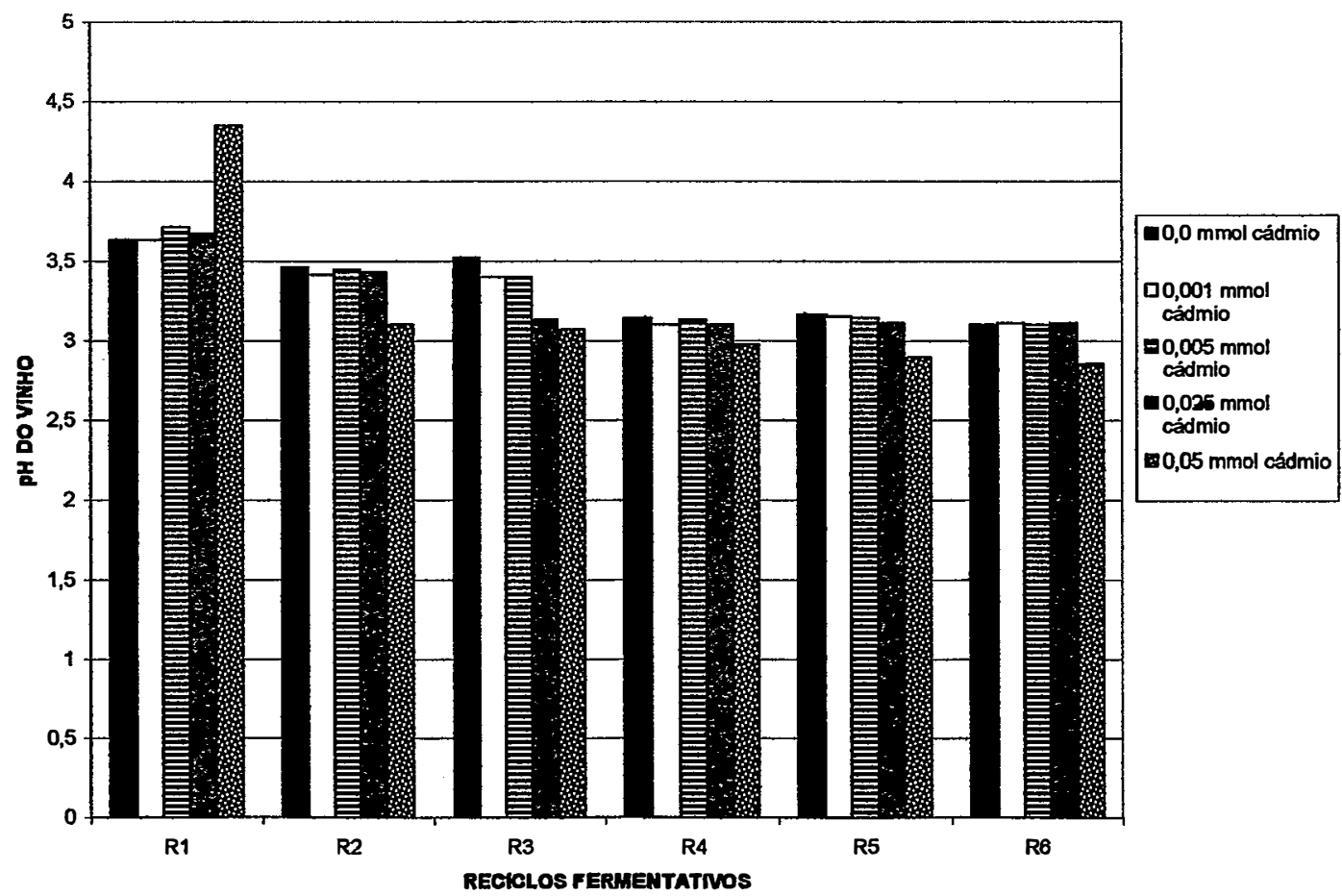

Figura 16 - Efeito de cinco concentrações de cádmio sobre o pH do vinho, no transcorrer de 6 reciclos fermentativos. 


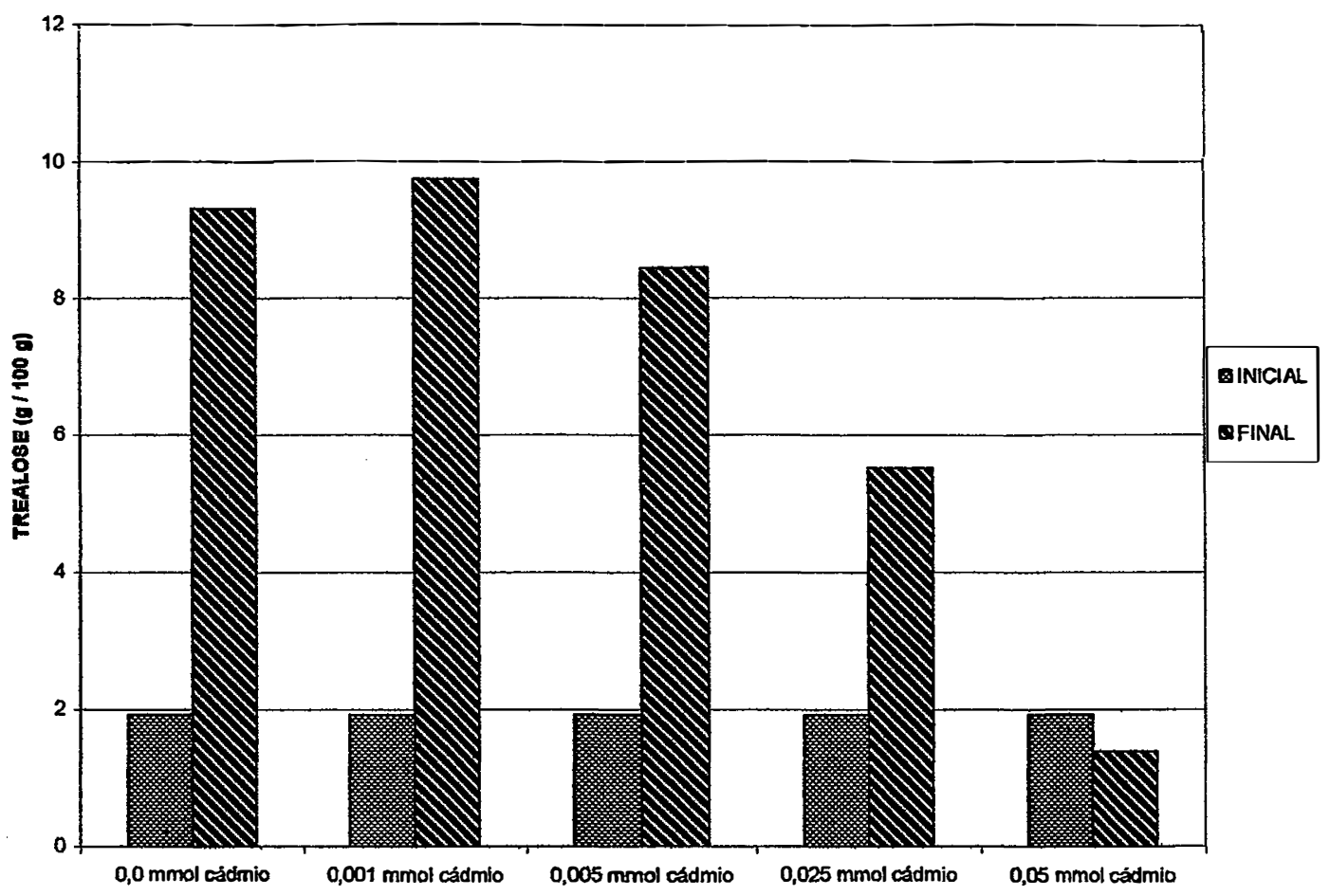

Figura 17 - Efeito de cinco concentrações de cádmio sobre os teores de trealose ( g $100 \mathrm{~g}^{-1}$ ) nos fermentos do início do experimento e do final do último ciclo fermentativo.

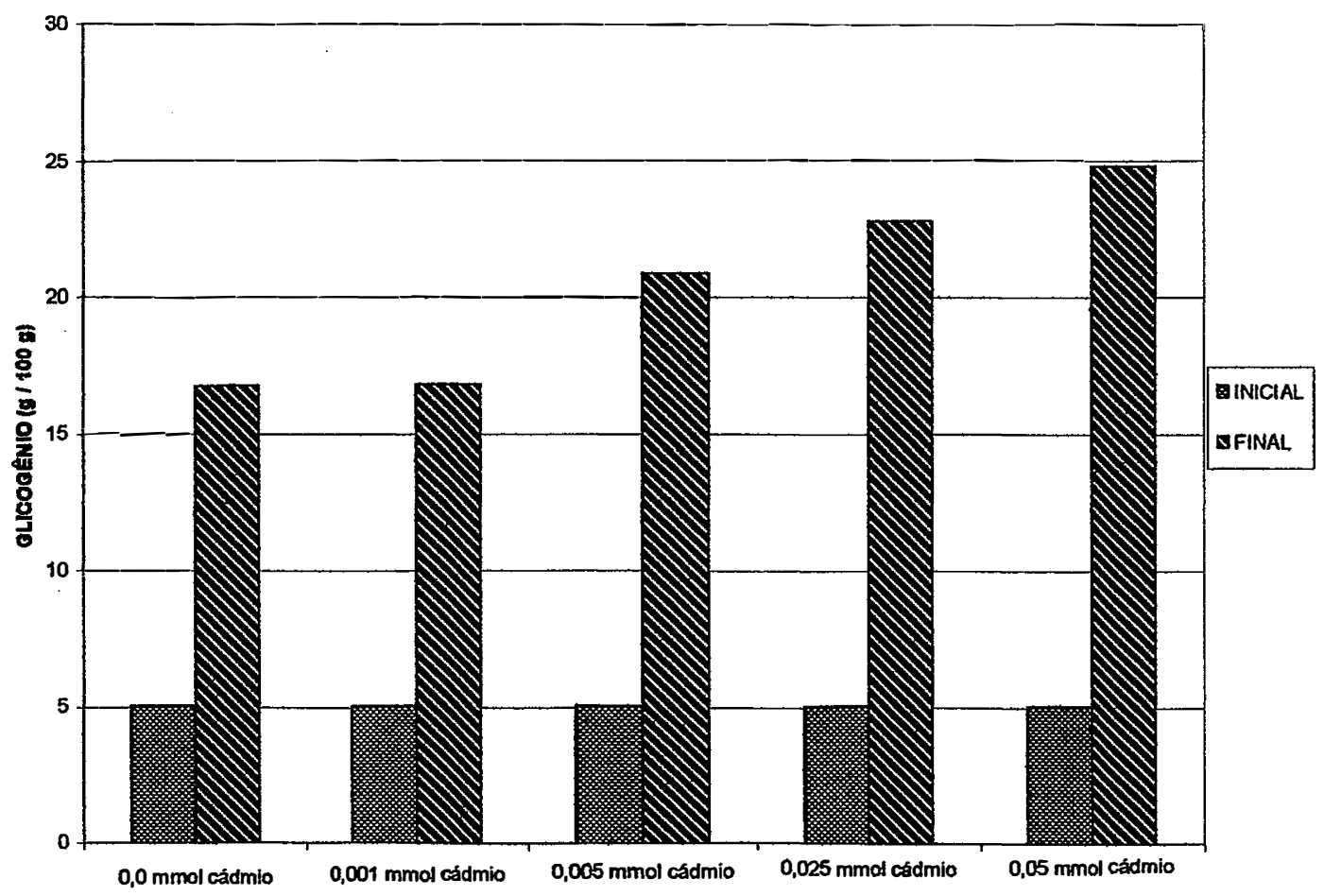

Figura 18 - Efeito de cinco concentrações de cádmio sobre os teores de glicogênio (g $\left.100 \mathrm{~g}^{-1}\right)$ nos fermentos do início do experimento e do final do último ciclo fermentativo. 


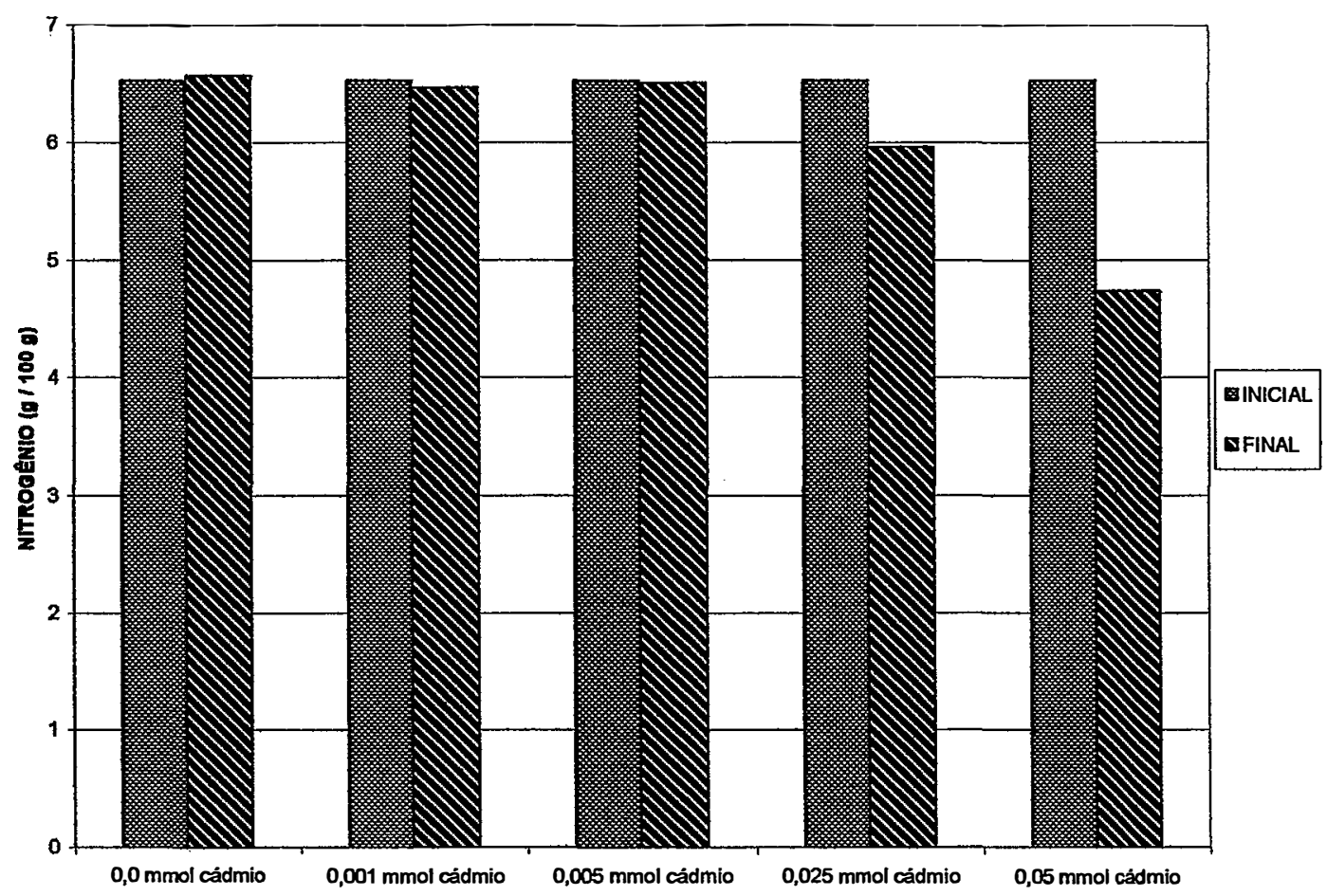

Figura 19 - Efeito de cinco concentrações de cádmio sobre os teores de nitrogênio nos fermentos do início do experimento e do final do último ciclo fermentativo.

Nas Figuras 20 à 25 pode ser observada a produção de $\mathrm{CO}_{2}(\mathrm{~g})$ nos diferentes tratamentos $\left(0,0 ; 0,001 ; 0,005,0,025\right.$ e $\left.0,05 \mathrm{mmol} \mathrm{de} \mathrm{Cd} \mathrm{L} \mathrm{L}^{-1}\right)$ durante os 6 ciclos fermentativos.

Através da produção de $\mathrm{CO}_{2}$ pode ser estimada a cinética da fermentação. 


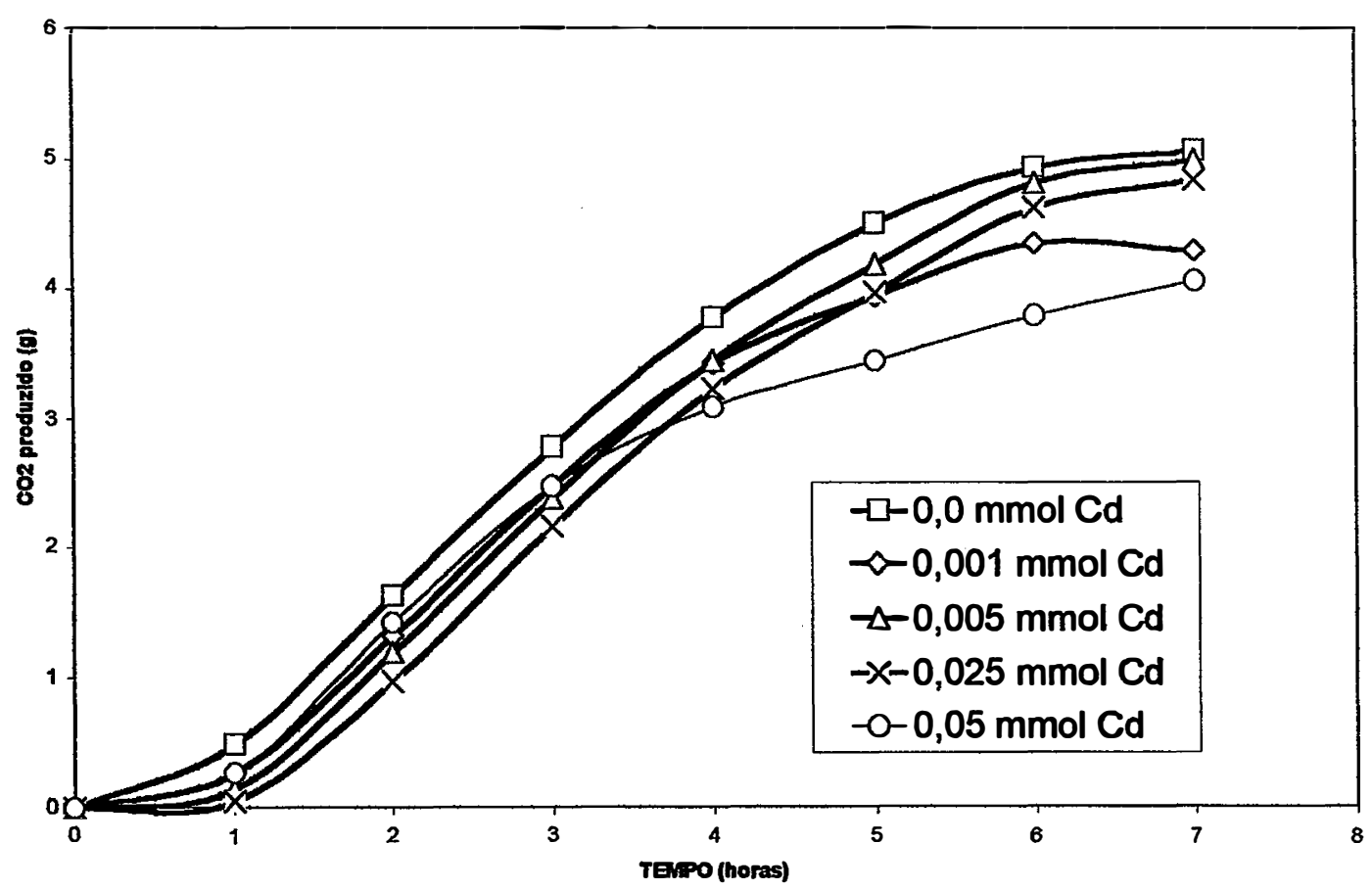

Figura 20 - Produção de $\mathrm{CO}_{2}$ durante o primeiro ciclo.

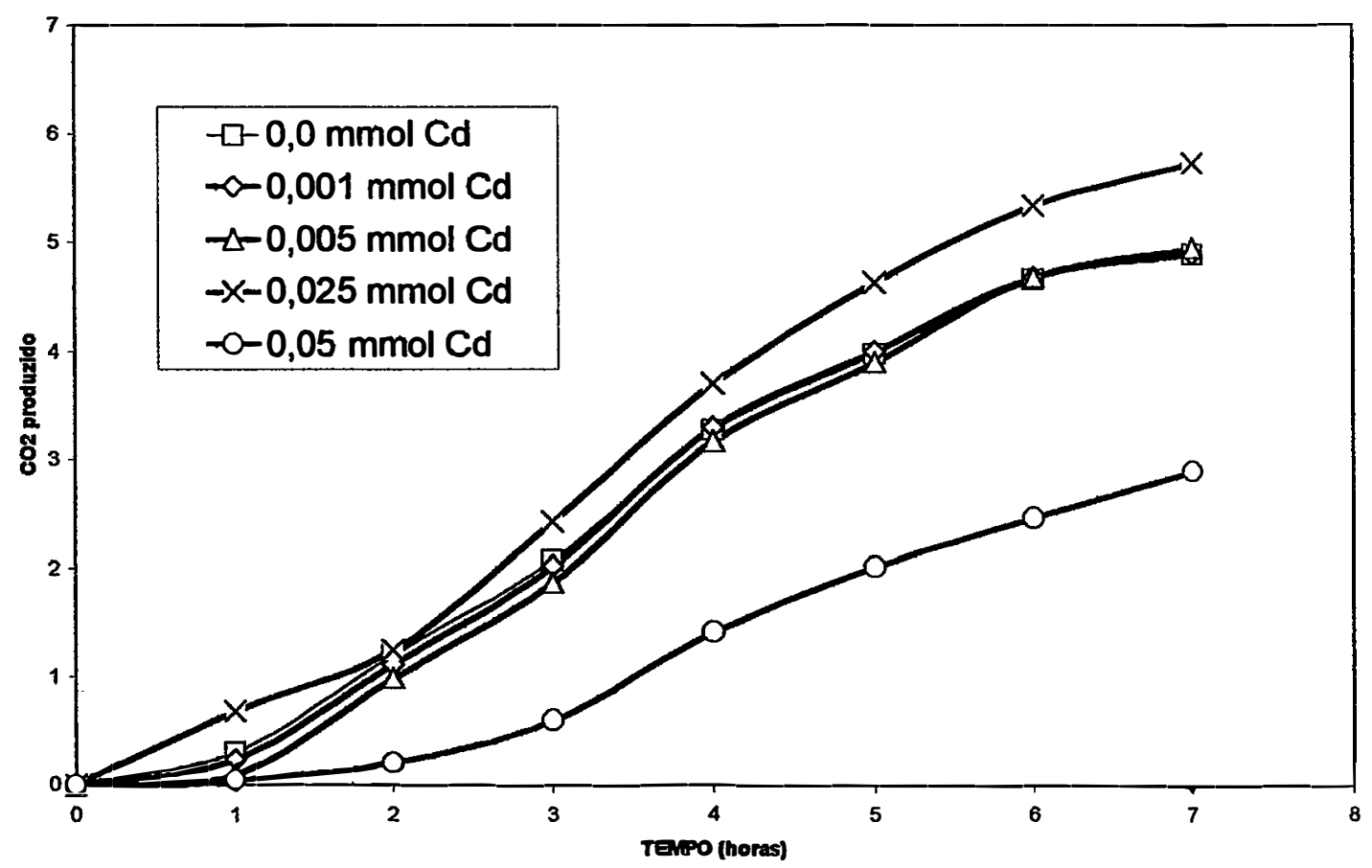

Figura 21 - Produção de $\mathrm{CO}_{2}$ durante o segundo ciclo. 


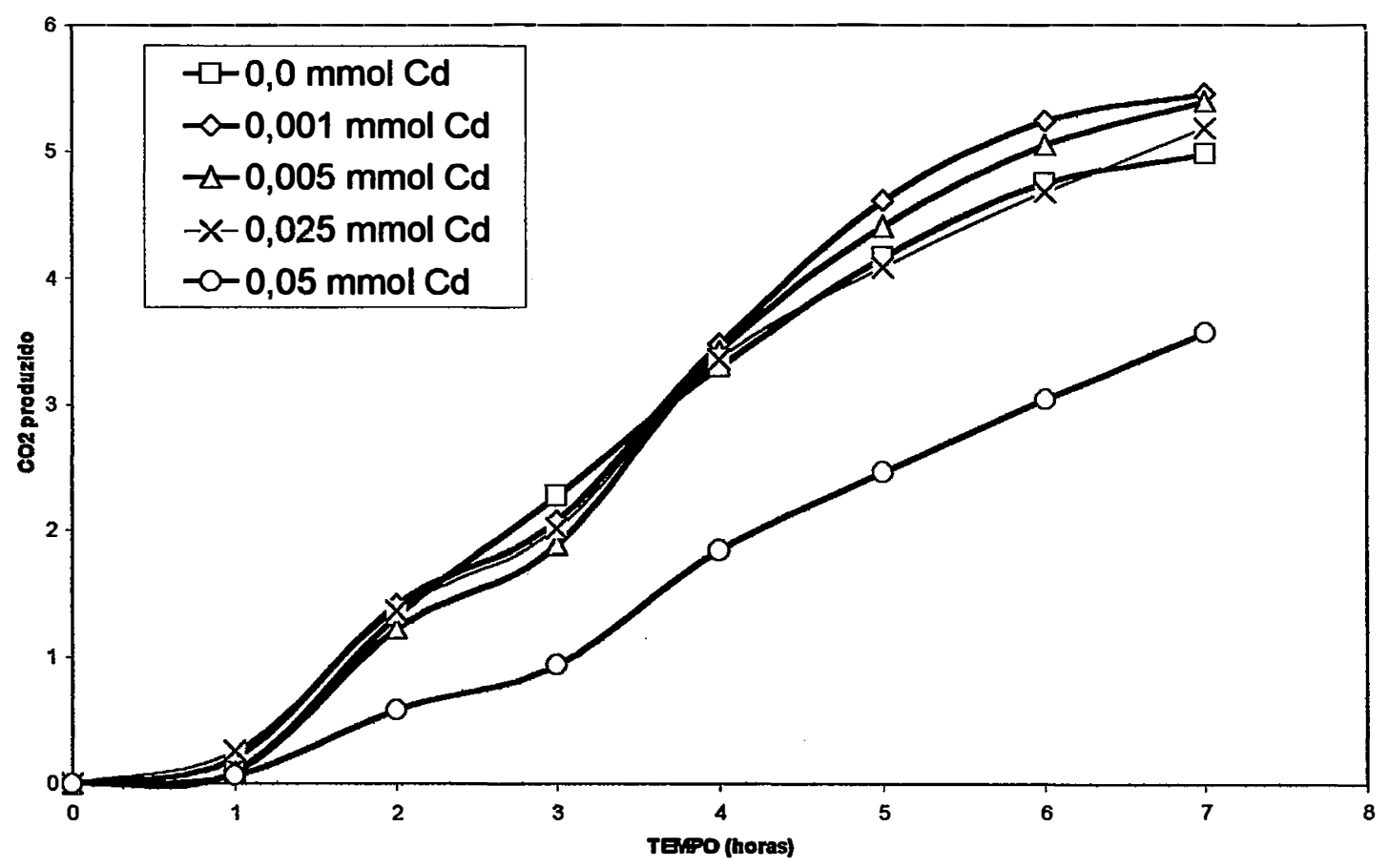

Figura 22 - Produção de $\mathrm{CO}_{2}$ durante o terceiro ciclo.

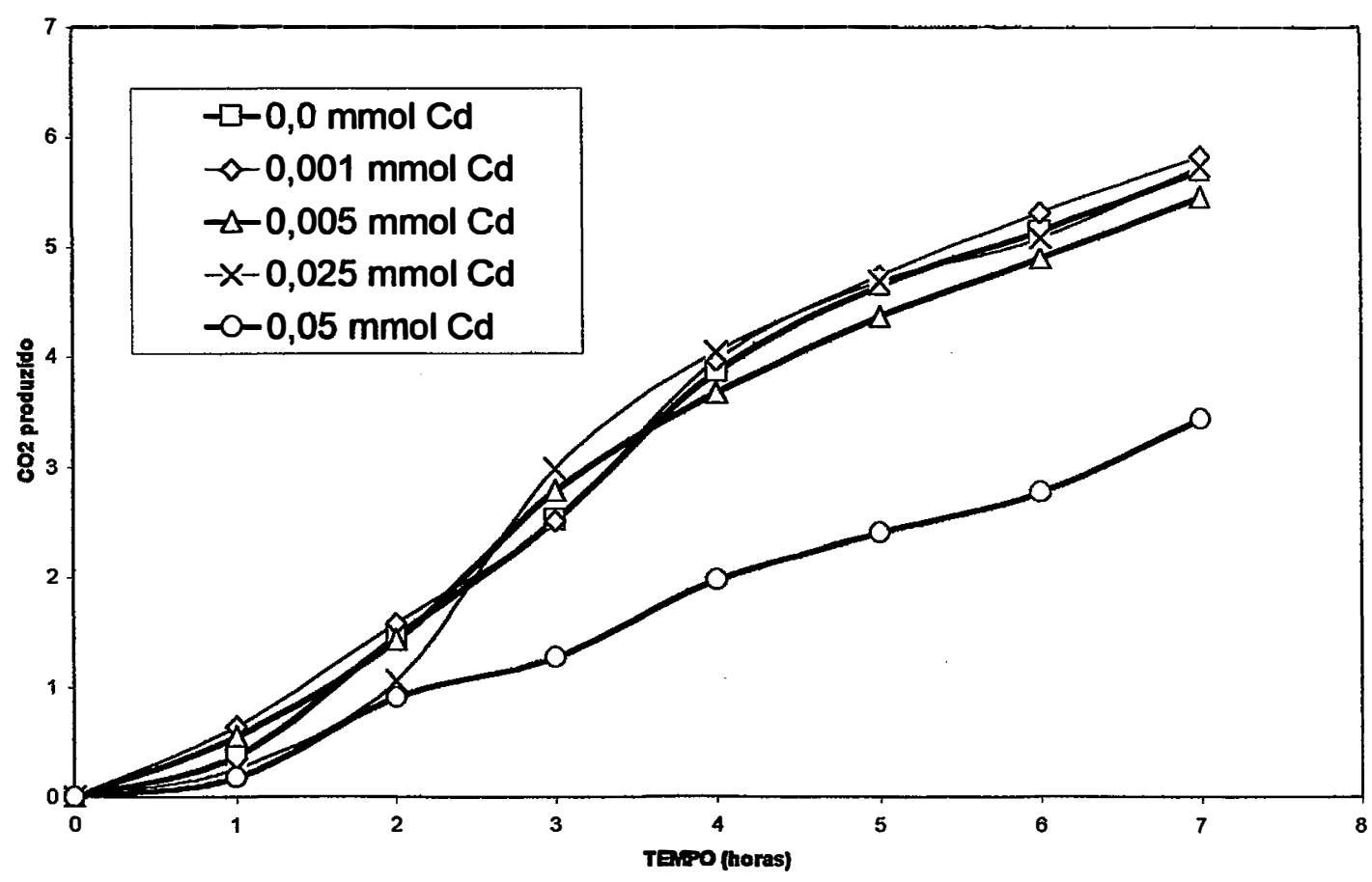

Figura 23 - Produção de $\mathrm{CO}_{2}$ durante o quarto ciclo. 


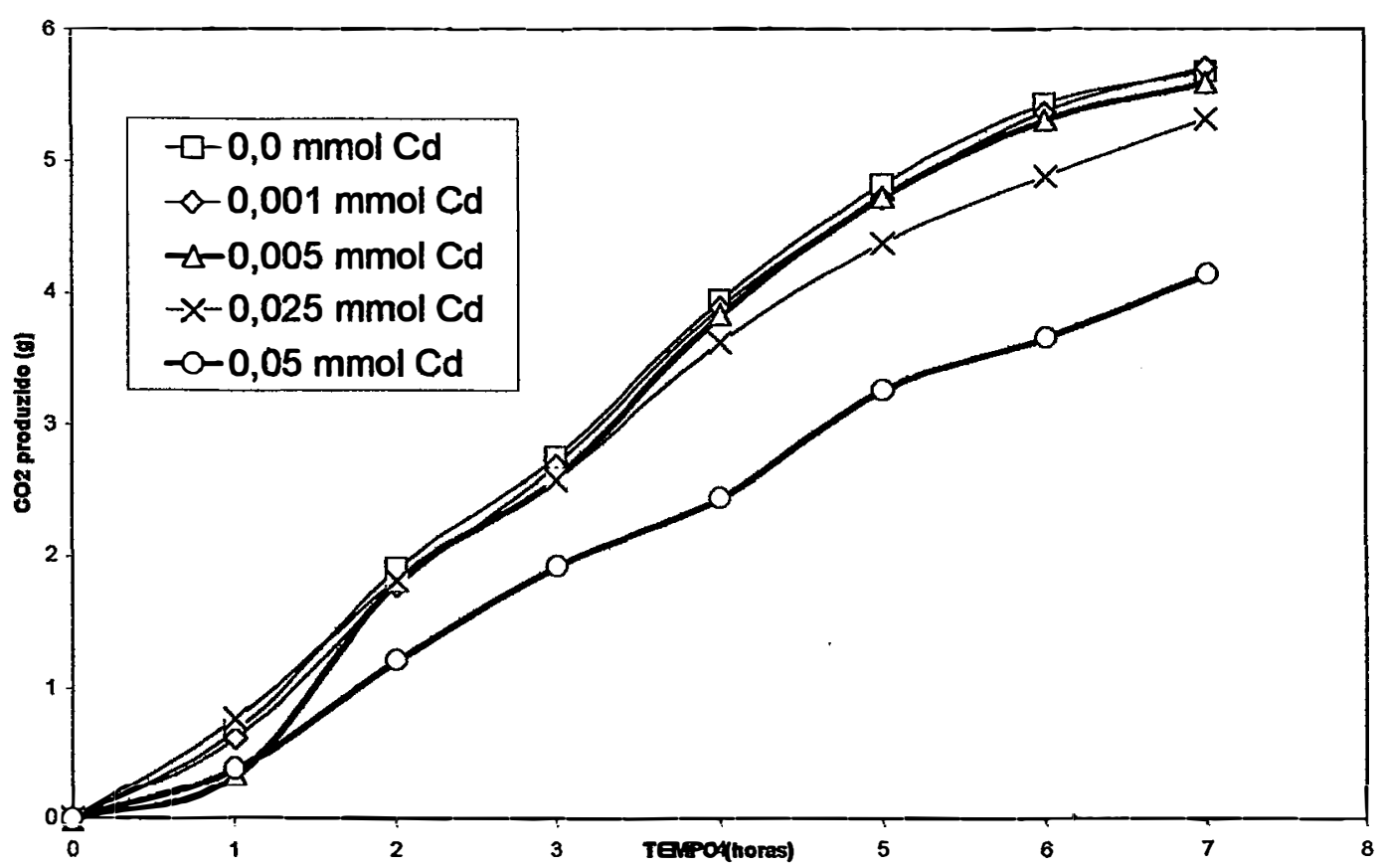

Figura 24 - Produção de $\mathrm{CO}_{2}$ durante o quinto ciclo. 


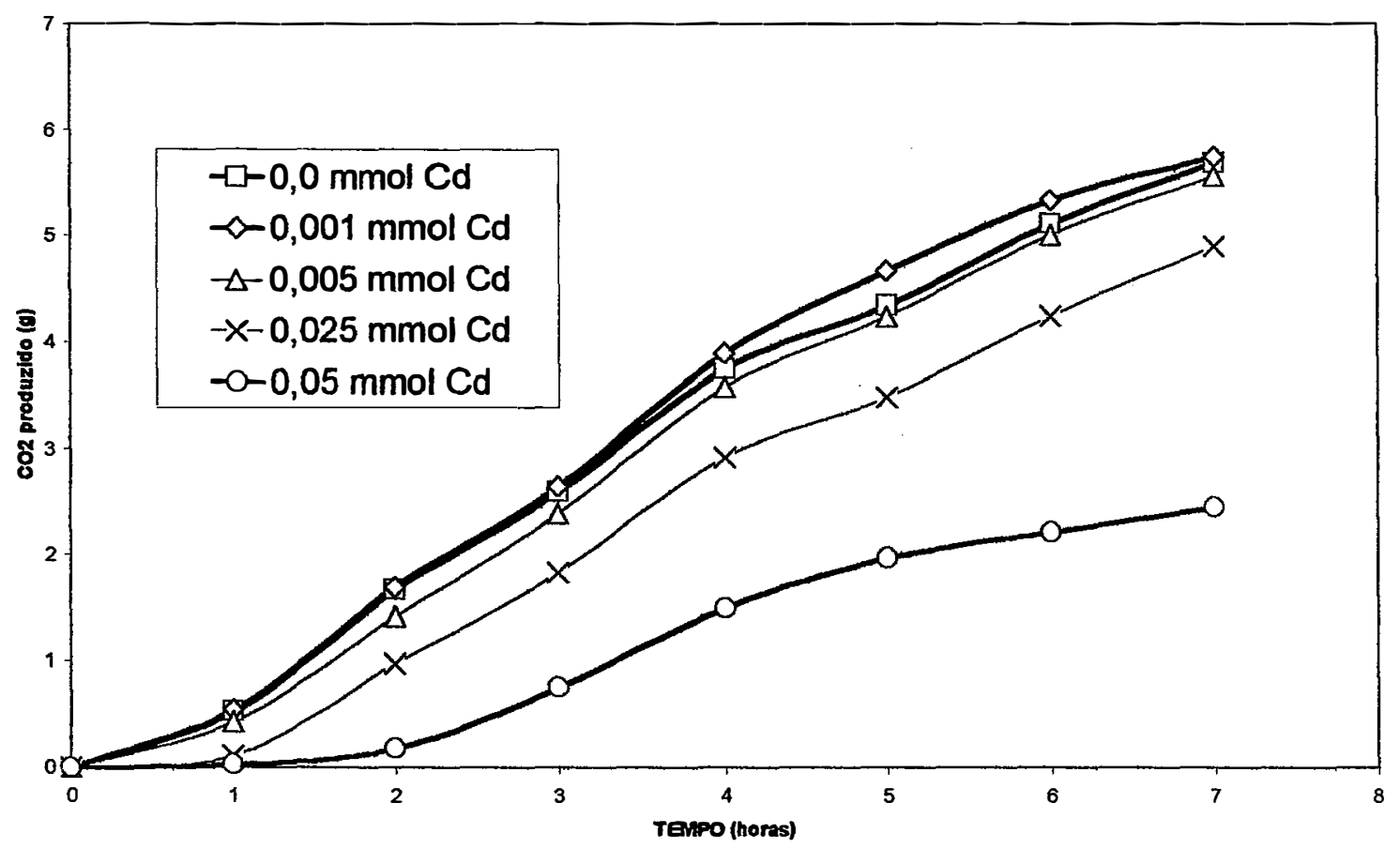

Figura 25 - Produção de $\mathrm{CO}_{2}$ durante o sexto ciclo. 
Nos Anexos de 9 à 14 encontram-se os valores que deram origem aos gráficos apresentados nas Figuras 7 à 25 .

Apesar da viabilidade ter sido afetada por 0,025 e $0,05 \mathrm{mmol} \mathrm{L}^{-1}$ de cádmio a partir do primeiro reciclo e por todas as concentrações a partir do quinto reciclo (Figura 13), o rendimento fermentativo, no transcorrer dos 6 ciclos fermentativos, somente foi afetado por $0,05 \mathrm{mmol} \mathrm{L}^{-1}$ de cádmio (Figura 7). Esta manutenção do rendimento fermentativo já havia sido notada por Domingos (1996) que trabalhando com concentrações entre 0,005 e $0,045 \mathrm{mmol} \mathrm{L}^{-1} \mathrm{em}$ meio de melaço, não notou qualquer alteração no rendimento fermentativo e na viabilidade de células de levedura de panificação. $O$ meio de melaço, muito mais complexo que o meio de caldo de cana, certamente proporcionou uma proteção adicional às células de levedura, explicando o porque da viabilidade não ter sido afetada. Por outro lado, o autor trabalhou com somente um reciclo, minimizando a toxicidade do metal.

Os teores de glicerol não variaram significativamente ao longo dos reciclos (Figura 10). Gutierrez et al., (1991) já havia notado que o níquel não alterava as quantidades de glicerol produzidas durante a fementação alcoólica. Se o mecanismo de inibição da desidrogenase alcoólica por metais pesados proposto por Fubrmann \& Rothstein (1968) fosse válido para níquel e cádmio, maiores quantidades de glicerol e acetaldeído deveriam ser formadas, pois com a desidrogenase alcoólica inibida, a levedura utilizaria a formação de glicerol para 
regenerar a coenzima NAD. O cádmio, como o níquel, parece atuar sobre a absorção de açúcares pelas células, e não inibindo a desidrogenase alcoólica.

No entanto Pons \& Chanel (1991), trabalhando com mosto de uva contaminado com cádmio, notaram um aumento na produção de acetaldeído e etanol, em concentrações de cádmio maiores que $1,0 \mathrm{mmol} \mathrm{L}^{-1}$. Infelizmente os autores não mensuraram os teores de glicerol. Provavelmente, à partir desta concentração $\left(1,0 \mathrm{mmol} \mathrm{L}^{-1}\right)$, o cádmio passa a afetar a desidrogenase alcoólica.

Apesar do cádmio ser conhecido como agente inibidor da invertase (Myrbäck, 1955), observando-se a Figura 15, nota-se que a taxas de sacarose residual nos vinhos não apresentaram variação significativa em nenhum dos tratamentos. No entanto, no tratamento com $0,05 \mathrm{mmol} \mathrm{L}^{-1}$ podem ser observados altos teores de glicose e frutose residual (Figuras 11 e 12). Sabe-se que a invertase é produzida pela levedura Saccharomyces cerevisiae em grandes quantidades (Griffin, 1994). O cádmio normalmente é um inibidor enzimático não competitivo, sendo que a concentração mais alta de cádmio utilizada em nossos ensaios $\left(0,05 \mathrm{mmol} \mathrm{L}^{-1}\right)$ provavelmente é insuficiente para inibir toda a enzima produzida.

Portanto, a sacarose é quebrada pela invertase em glicose e frutose, porém a levedura é incapaz de metabolizar totalmente estes dois açúcares.

As curvas de $\mathrm{CO}_{2}$ produzido (Figuras 20 à 26) demonstram claramente os efeitos tóxicos do cádmio, refletindo os demais parâmetros fisiológicos 
(viabilidade, produção de etanol, etc.). Provavelmente, pela não entrada de açúcar na célula de levedura, ocorre uma diminuição da glicólise, traduzida pela menor produção de álcool e $\mathrm{CO}_{2}$.

Pode-se observar que $0,05 \mathrm{mmol} \mathrm{L}^{-1}$ de cádmio afetou a produção de $\mathrm{CO}_{2}$ a partir já do primeiro reciclo (Figura 20), enquanto que $0,025 \mathrm{mmol} \mathrm{L}^{-1}$ somente a partir do quito reciclo (Figuras 25 e 26).

Grafl \& Schwantes (1983b) já haviam utilizado o parâmetro produção de $\mathrm{CO}_{2}$ para avaliar os efeitos tóxicos de várias doses de cádmio $(0,0001$ até 100 mmol L ${ }^{-1}$ ) sobre Saccharomyces cerevisiae fermentando um mosto de glicose suplementado com minerais e vitaminas.. Os autores infelizmente não trabalharam com o reciclo de leveduras, mas os resultados obtidos são muito semelhantes a estes ora apresentados.

\subsection{Ensaio 4}

Nas Figuras de 26 à 38 são apresentados os resultados obtidos para rendimento, etanol, peso de fermento, viabilidade, brotamento, $\mathrm{pH}$ do vinho, glicerol no vinho, glicose residual, frutose residual, sacarose residual, trealose, glicogênio e nitrogênio. 


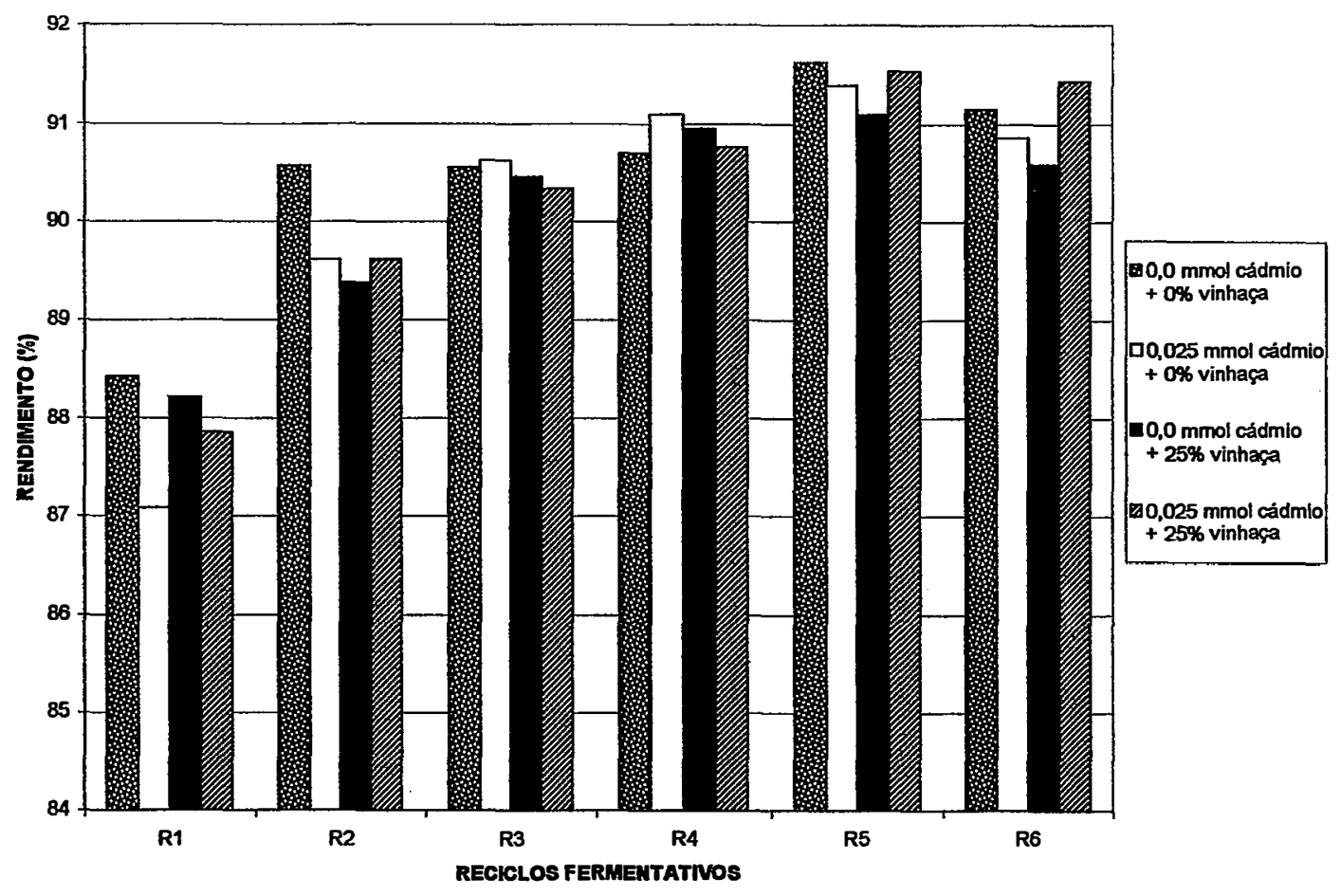

Figura 26 - Efeito de duas concentrações de cádmio combinadas com duas concentrações de vinhaça sobre o rendimento fermentativo (\%), no transcorrer de 6 reciclos fermentativos.

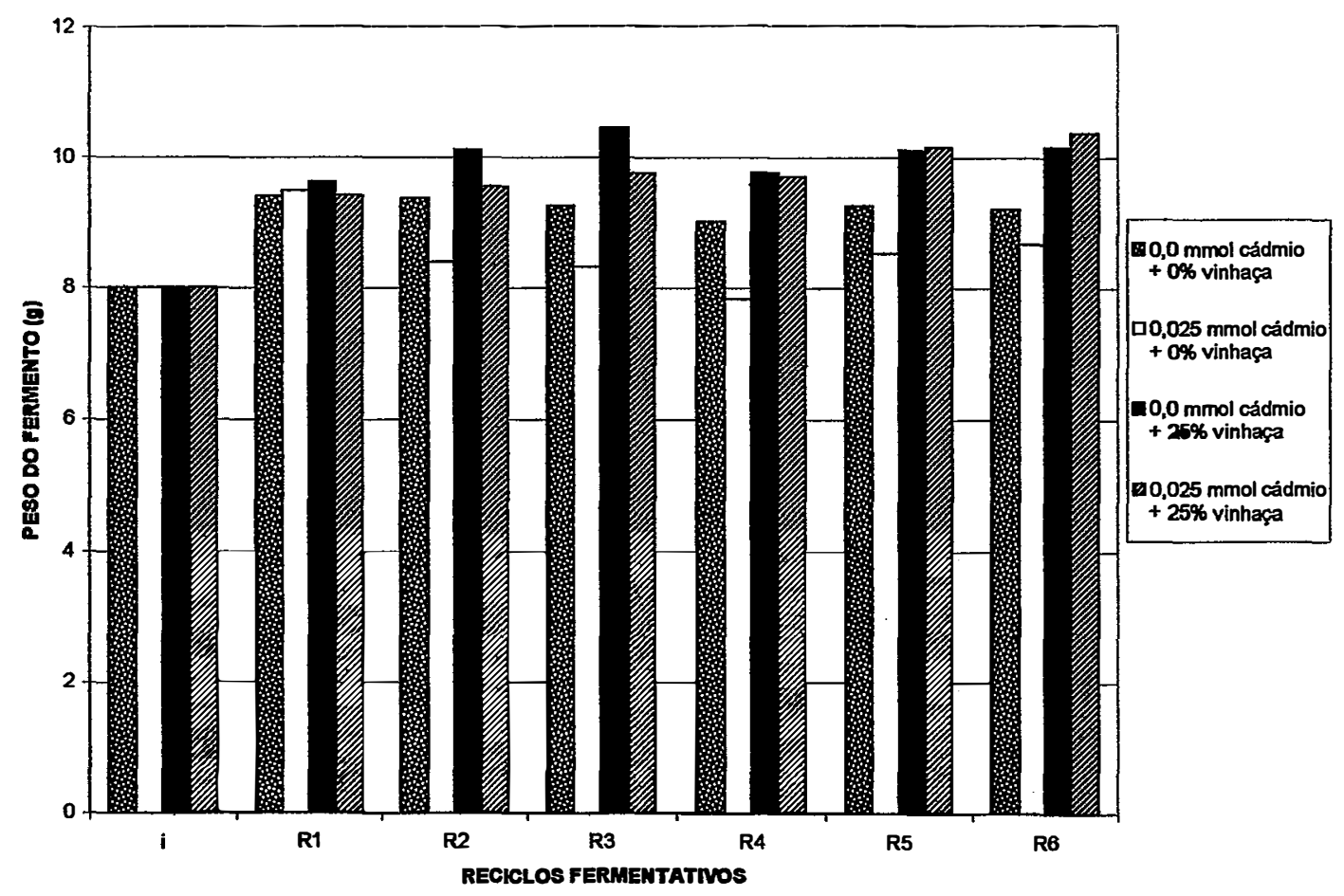

Figura 27 - Efeito de duas concentrações de cádmio combinadas com duas concentrações de vinhaça sobre o peso do fermento $(\mathrm{g})$, no transcorrer de 6 reciclos fermentativos. 


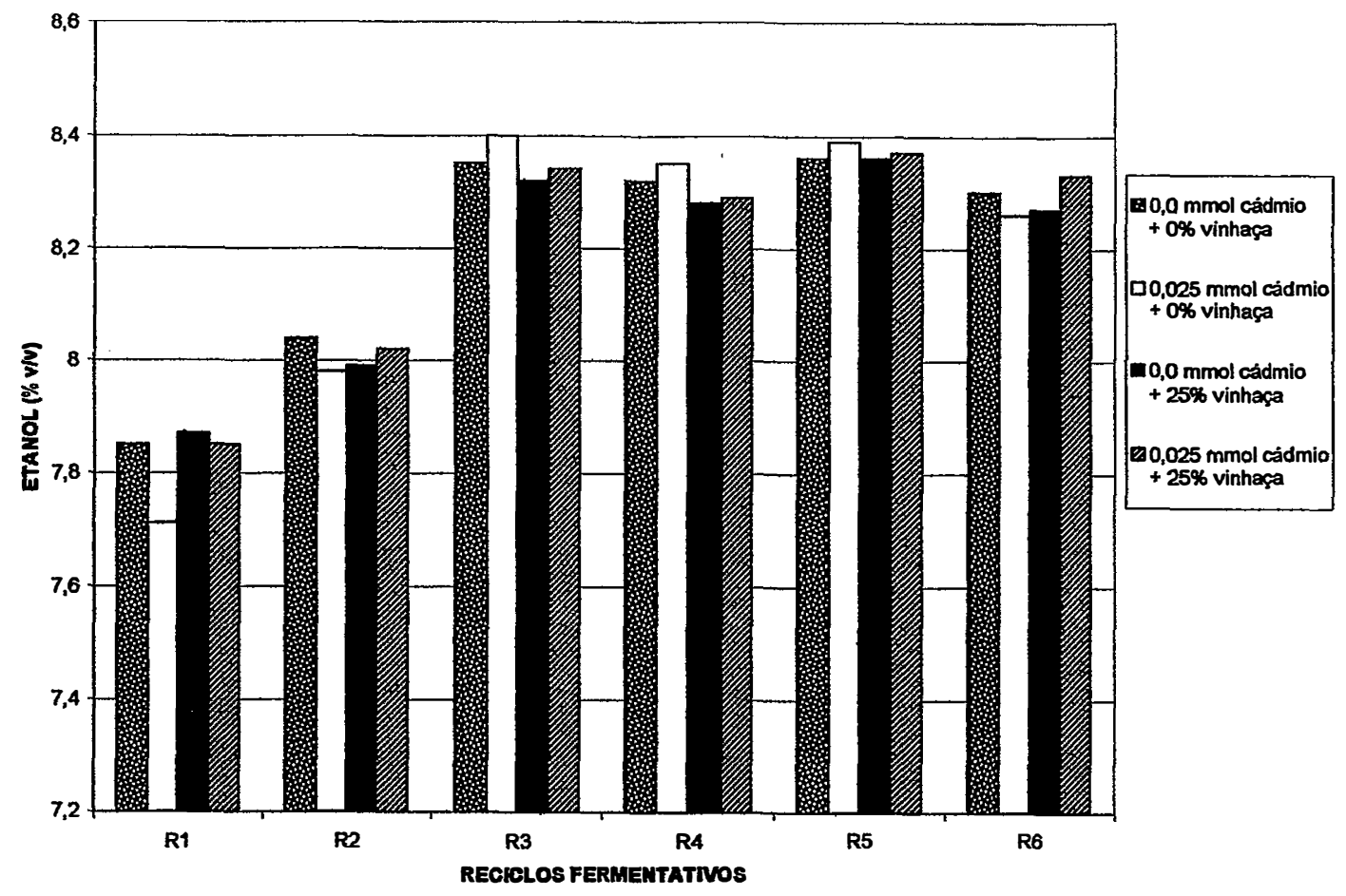

Figura 28 - Efeito de duas concentrações de cádmio combinadas com duas concentrações de vinhaça sobre a formação de etanol (\% v/v), no transcorrer de 6 reciclos fermentativos.

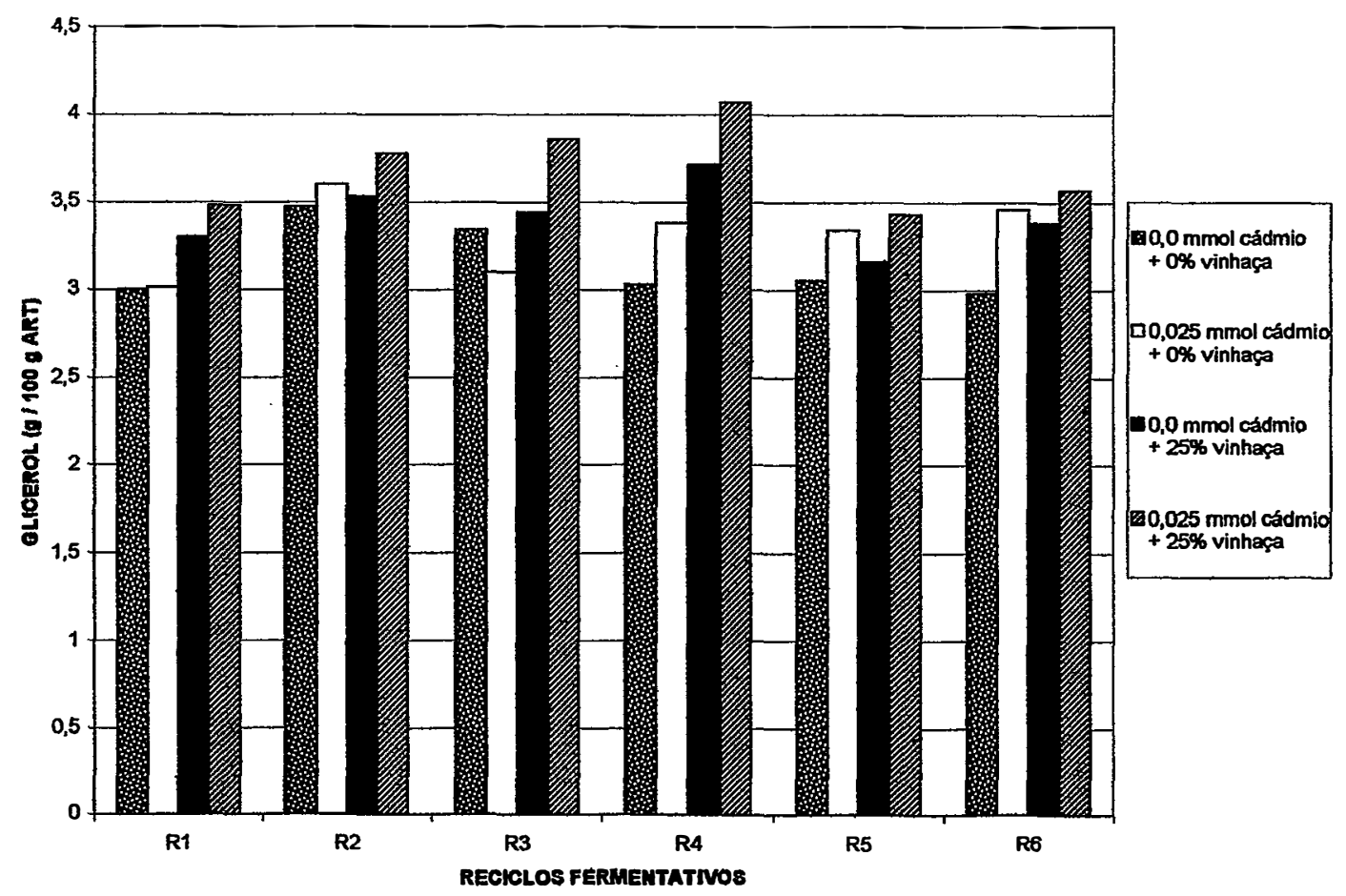

Figura 29 - Efeito de duas concentrações de cádmio combinadas com duas concentrações de vinhaça sobre a formação de glicerol (g / 100 g ART), no transcorrer de 6 reciclos fermentativos. 


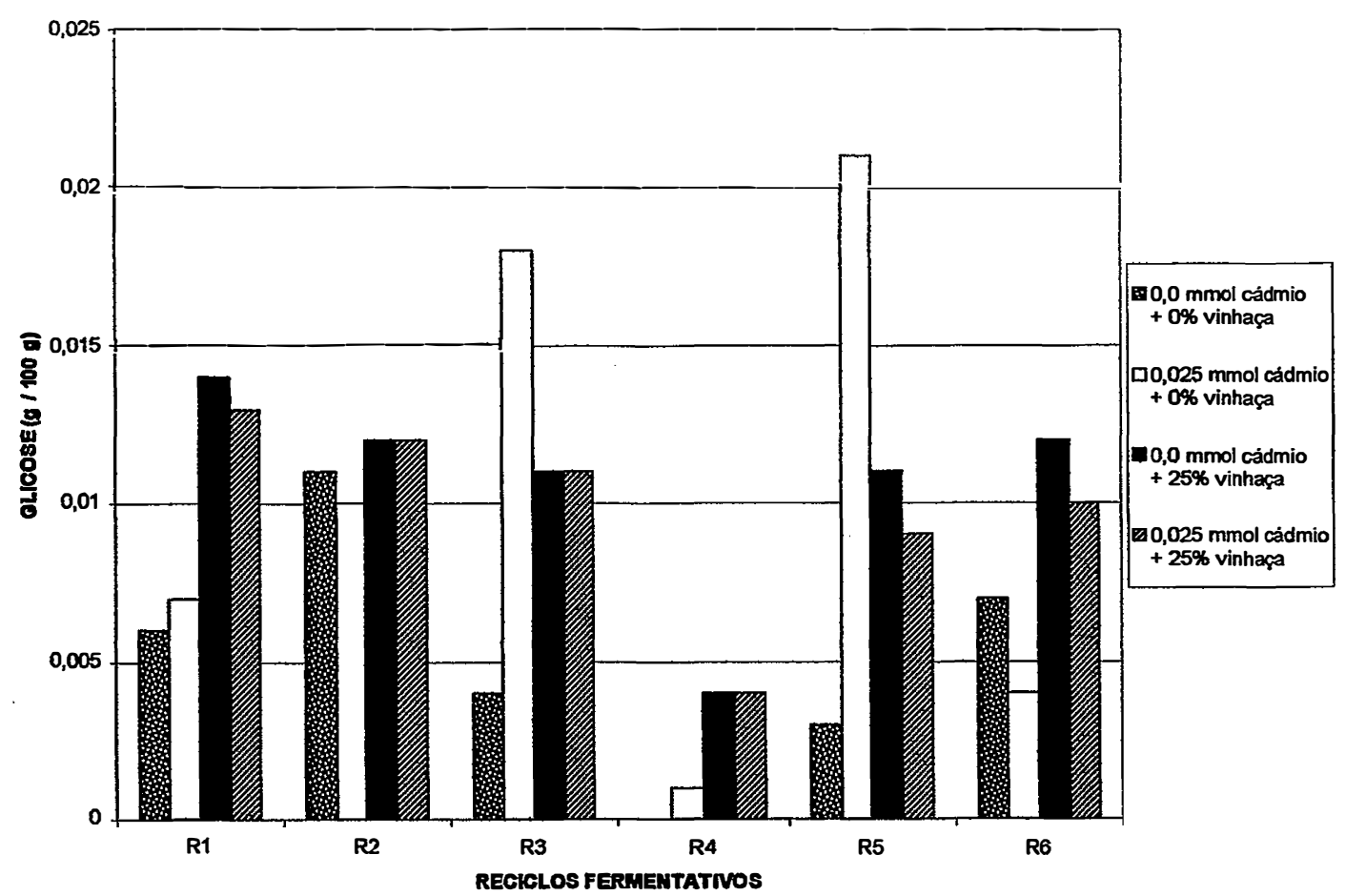

Figura 30 - Efeito de duas concentraçōes de cádmio combinadas com duas concentrações de vinhaça sobre a glicose residual no vinho $\left(\mathrm{g} 100 \mathrm{ml}^{-1}\right)$, no transcorrer de 6 reciclos fermentativos.

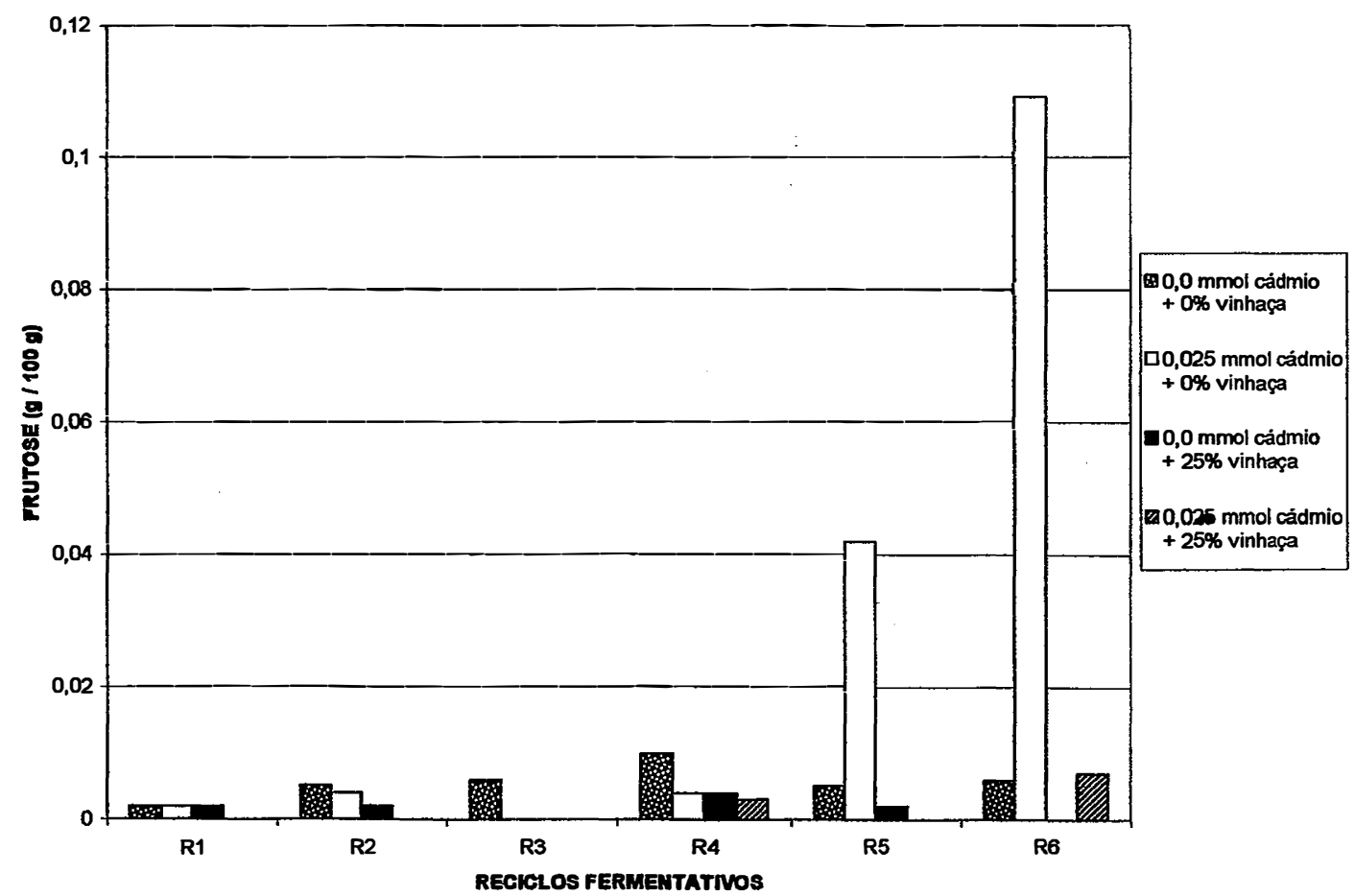

Figura 31 - Efeito de duas concentrações de cádmio combinadas com duas concentrações de vinhaça sobre a frutose residual no vinho $\left(\mathrm{g} 100 \mathrm{~mL}^{-1}\right)$, no transcorrer de 6 reciclos fermentativos. 


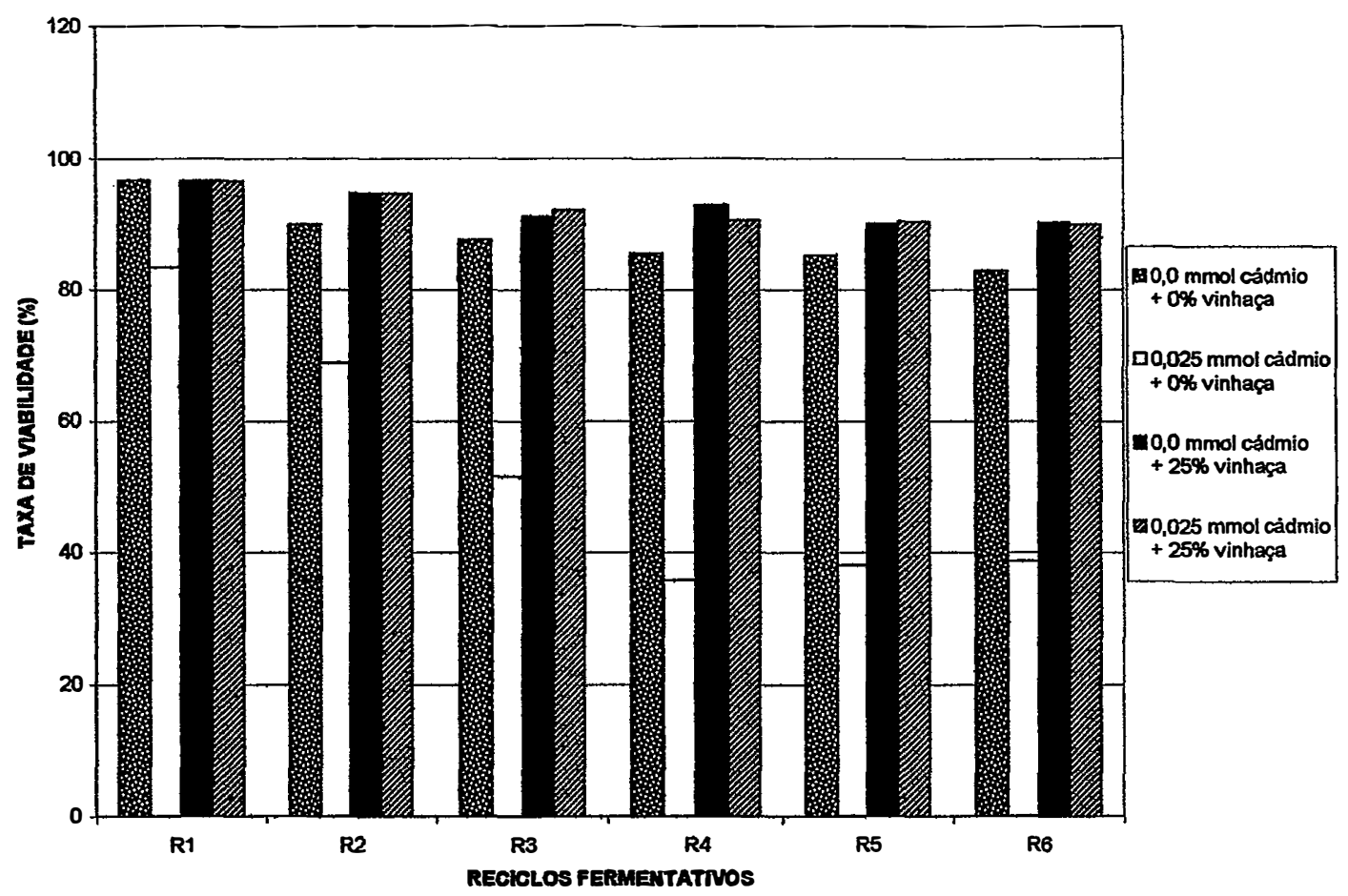

Figura 32 - Efeito de duas concentrações de cádmio combinadas com duas concentrações de vinhaça sobre a taxa de viabilidade do fermento (\%), no transcorrer de 6 reciclos fermentativos.

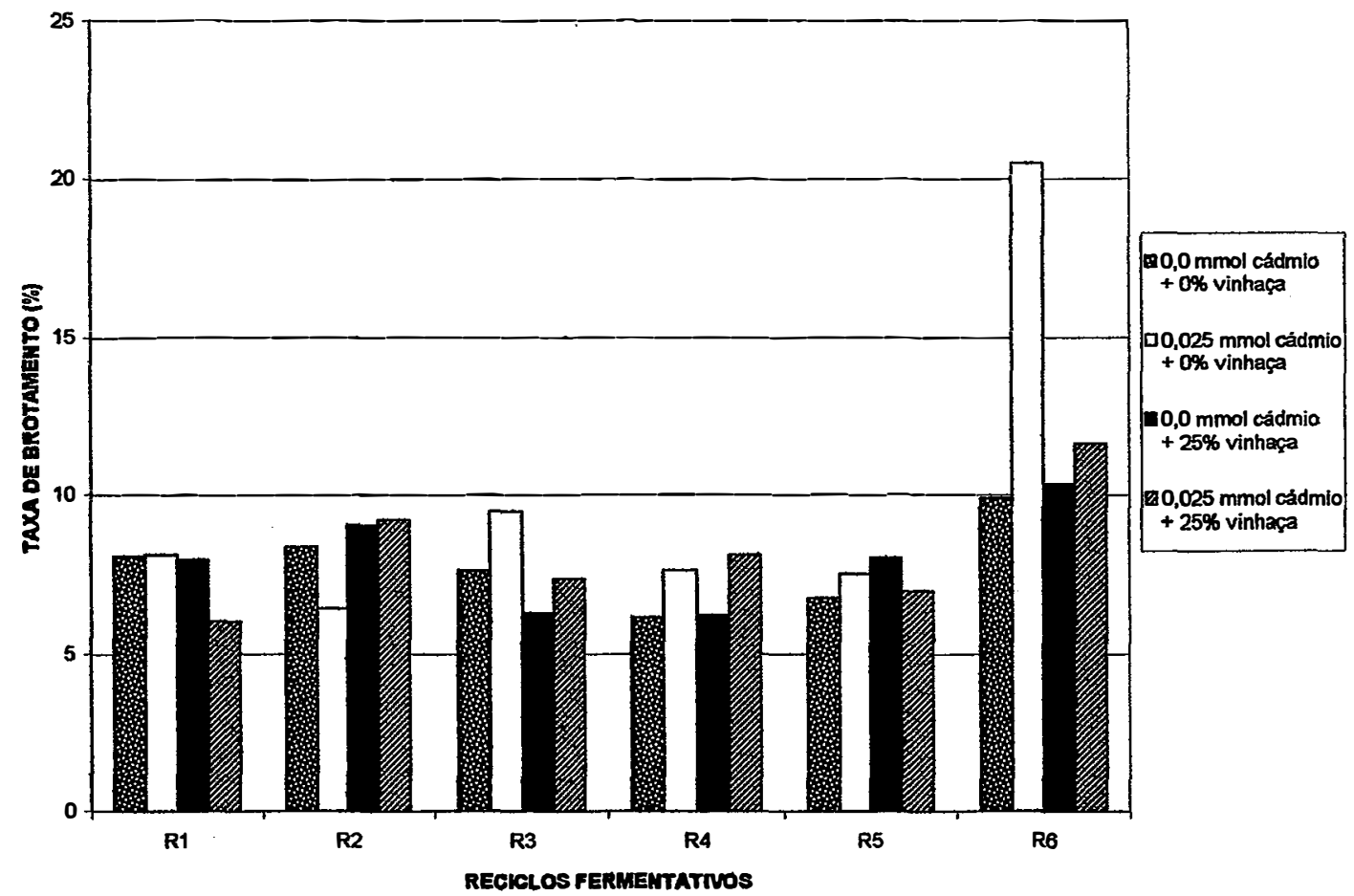

Figura 33 - Efeito de duas concentrações de cádmio combinadas com duas concentrações de vinhaça sobre a taxa de brotamento do fermento, no transcorrer de 6 reciclos fermentativos. 


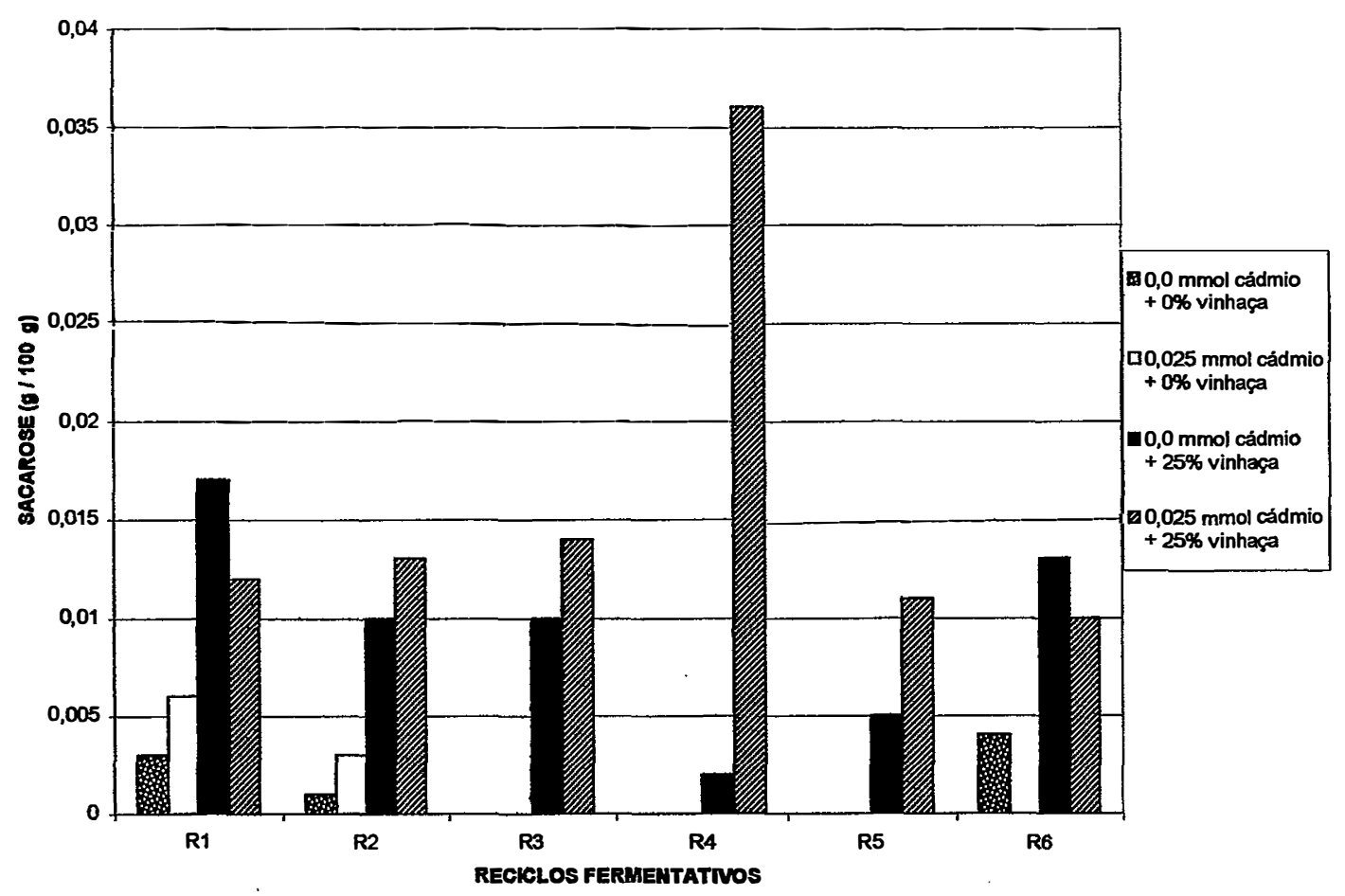

Figura 34 - Efeito de duas concentrações de cádmio combinadas com duas concentrações de vinhaça sobre a sacarose residual no vinho $\left(\mathrm{g} 100 \mathrm{~mL}^{-1}\right)$, no transcorrer de 6 reciclos fermentativos.

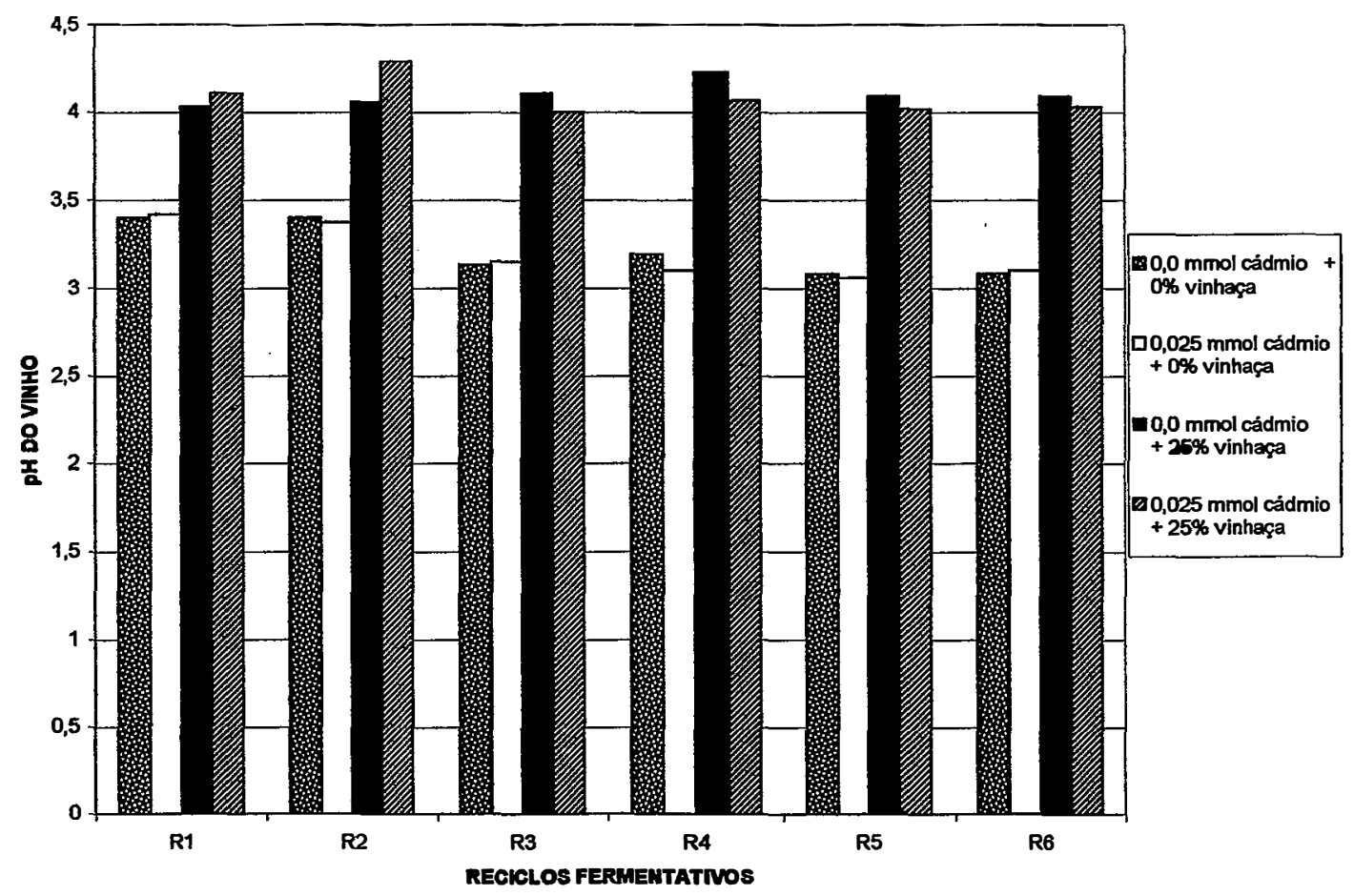

Figura 35 - Efeito de duas concentrações de cádmio combinadas com duas concentrações de vinhaça sobre o $\mathrm{pH}$ do vinho, no transcorrer de 6 reciclos fermentativos. 


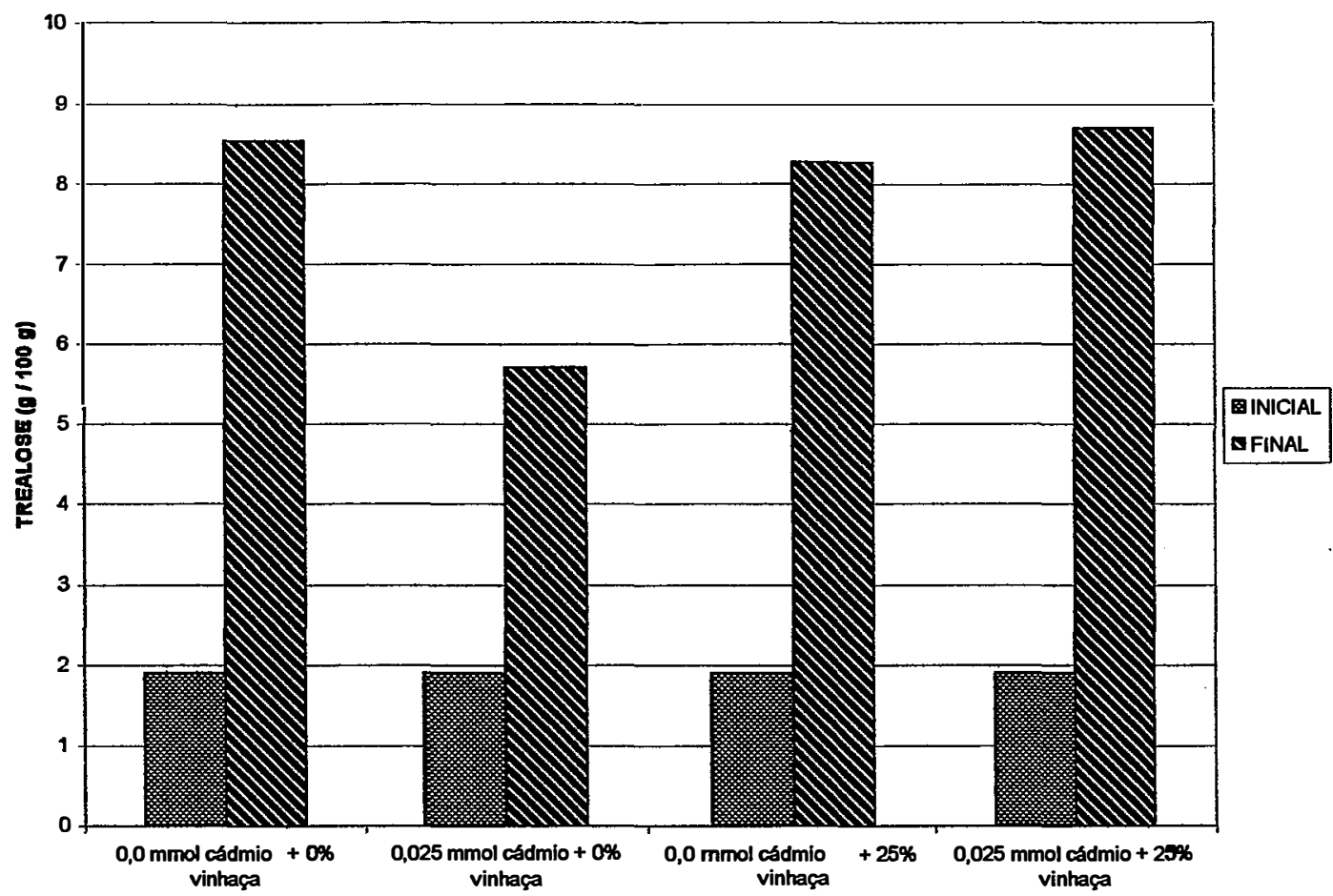

Figura 36 - Efeito de duas concentrações de cádmio combinadas com duas concentrações

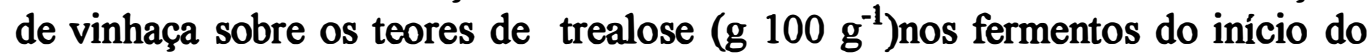
experimento e do final do último ciclo fermentativo.

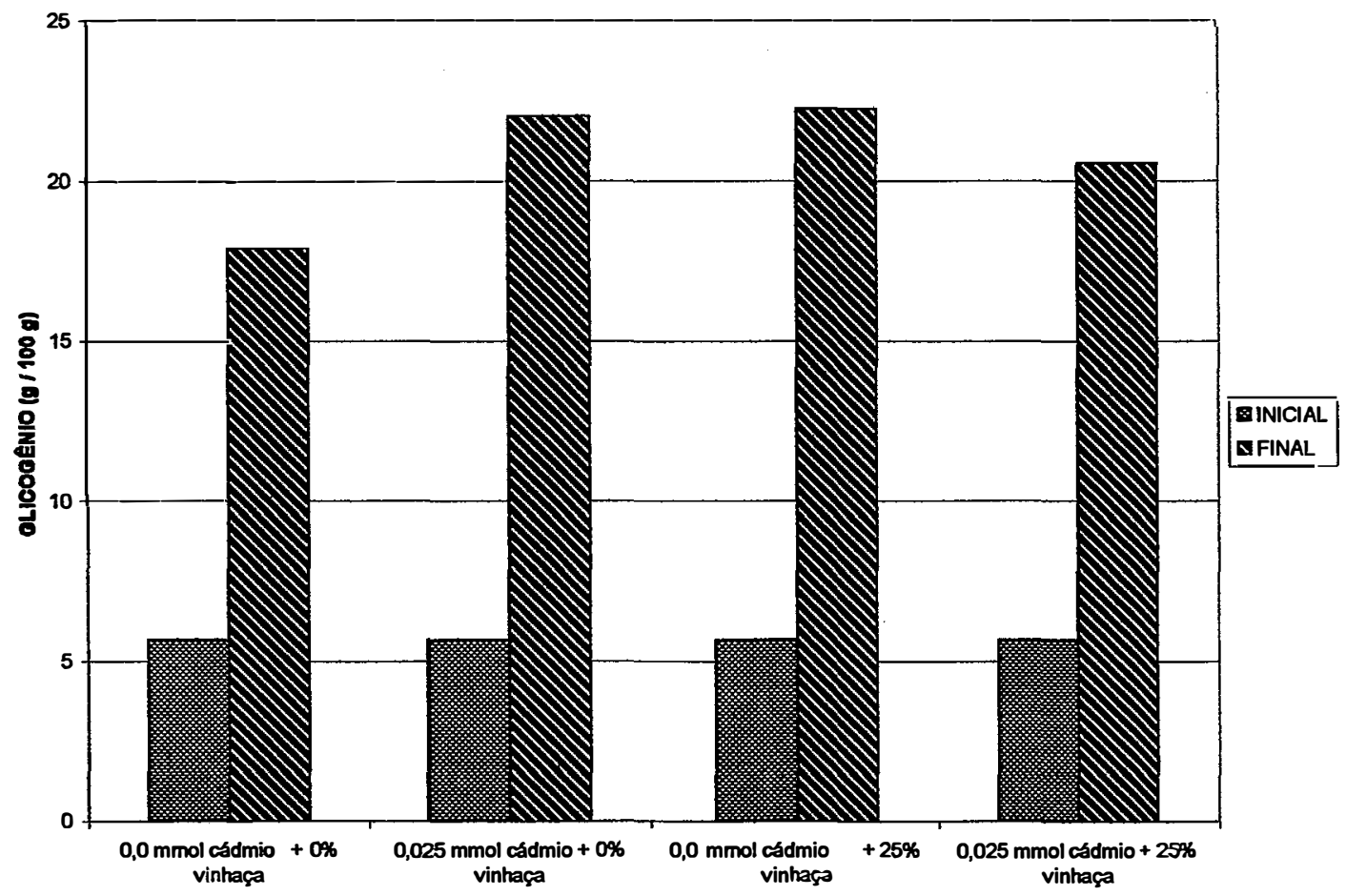

Figura 37 - Efeito de duas concentrações de cádmio combinadas com duas concentrações

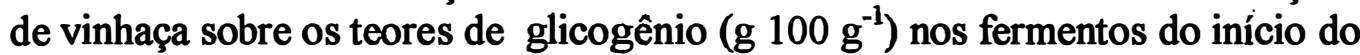
experimento e do final do último ciclo fermentativo. 


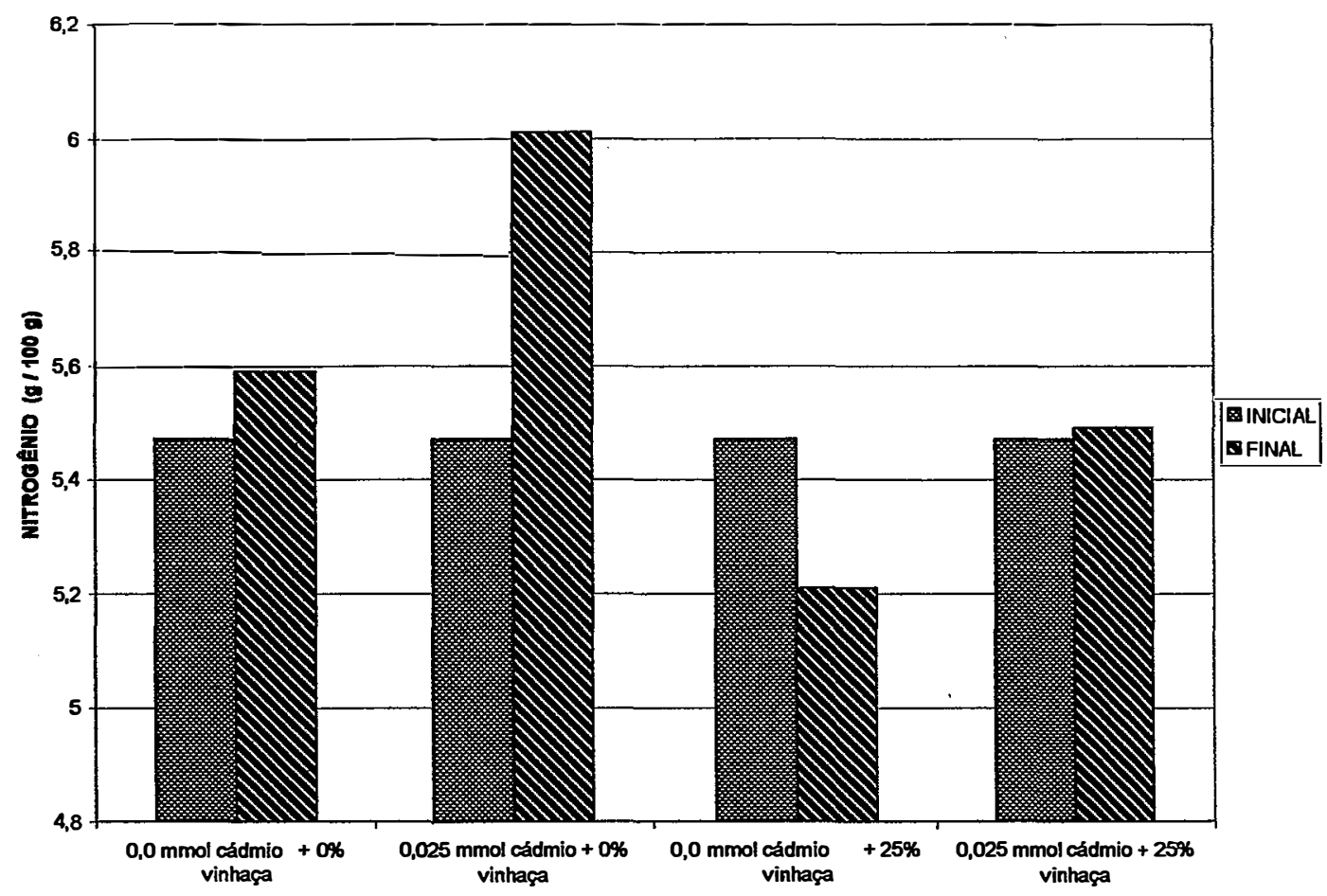

Figura 38 - Efeito de duas concentrações de cádmio combinadas com duas concentrações de vinhaça sobre os teores de nitrogênio (\%) nos fermentos do início do experimento e do final do último ciclo fermentativo.

Nas Figuras de 39 a 44 pode ser observada a produção de $\mathrm{CO}_{2}$ nos diferentes tratamentos $\left(0,0\right.$ mmol de $\mathrm{Cd} \mathrm{L}^{-1}+0 \%$ vinhaça; $0,025 \mathrm{mmol}$ de $\mathrm{Cd} \mathrm{L}^{-1}+0 \%$ vinhaça; 0,0 mmol de $C d L^{-1}+25 \%$ vinhaça; 0,025 mmol de $\mathrm{Cd} \mathrm{L}^{-1}+25 \%$ vinhaça) durante os 6 ciclos fermentativos

Nos Anexos de 16 à 21 encontram-se os valores que deram origem aos gráficos apresentados nas figuras de 26 à 44 . 


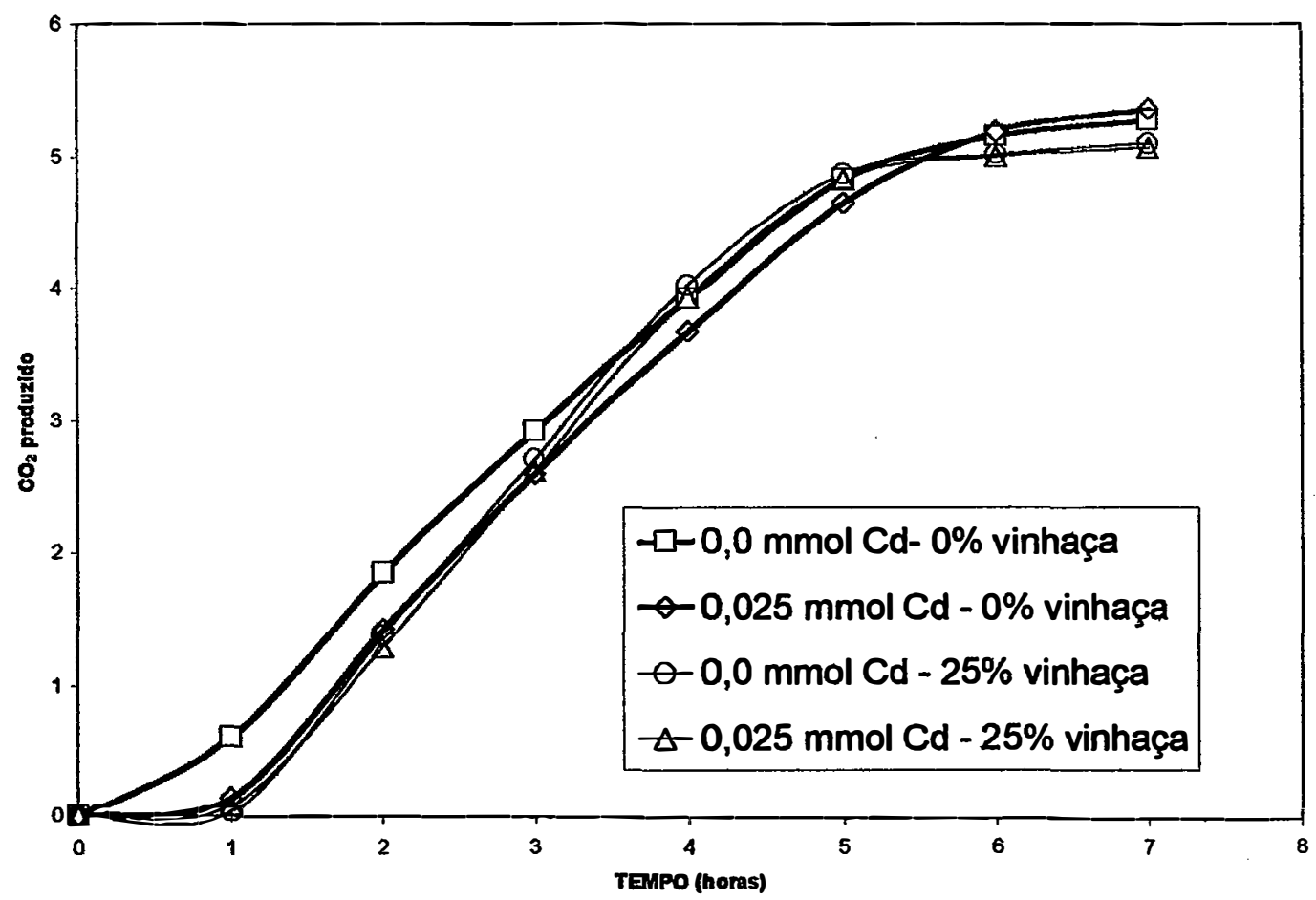

Figura 39 - Produção de $\mathrm{CO}_{2}$ durante o primeiro ciclo.

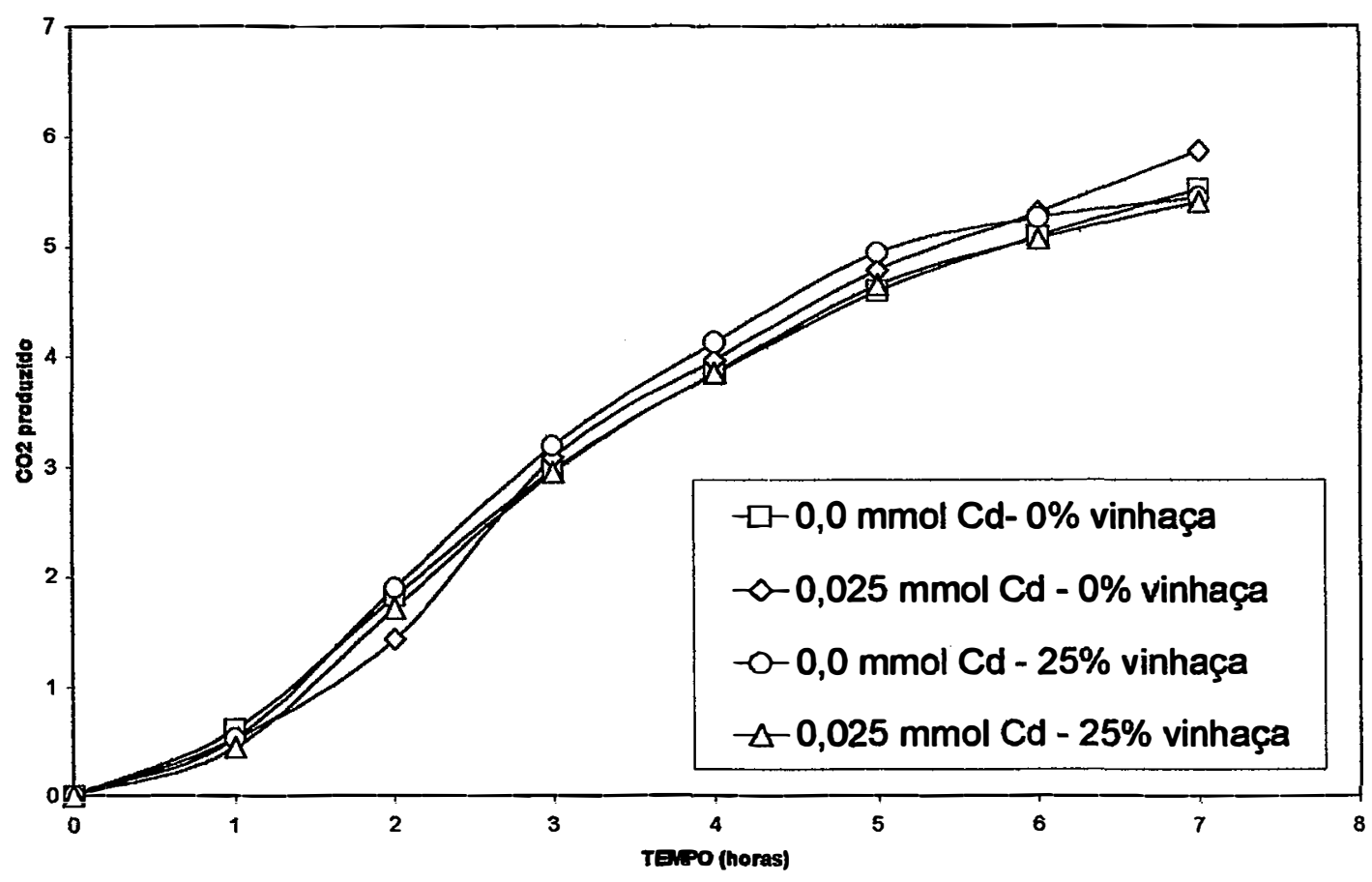

Figura 40 - Produção de $\mathrm{CO}_{2}$ durante o segundo ciclo. 


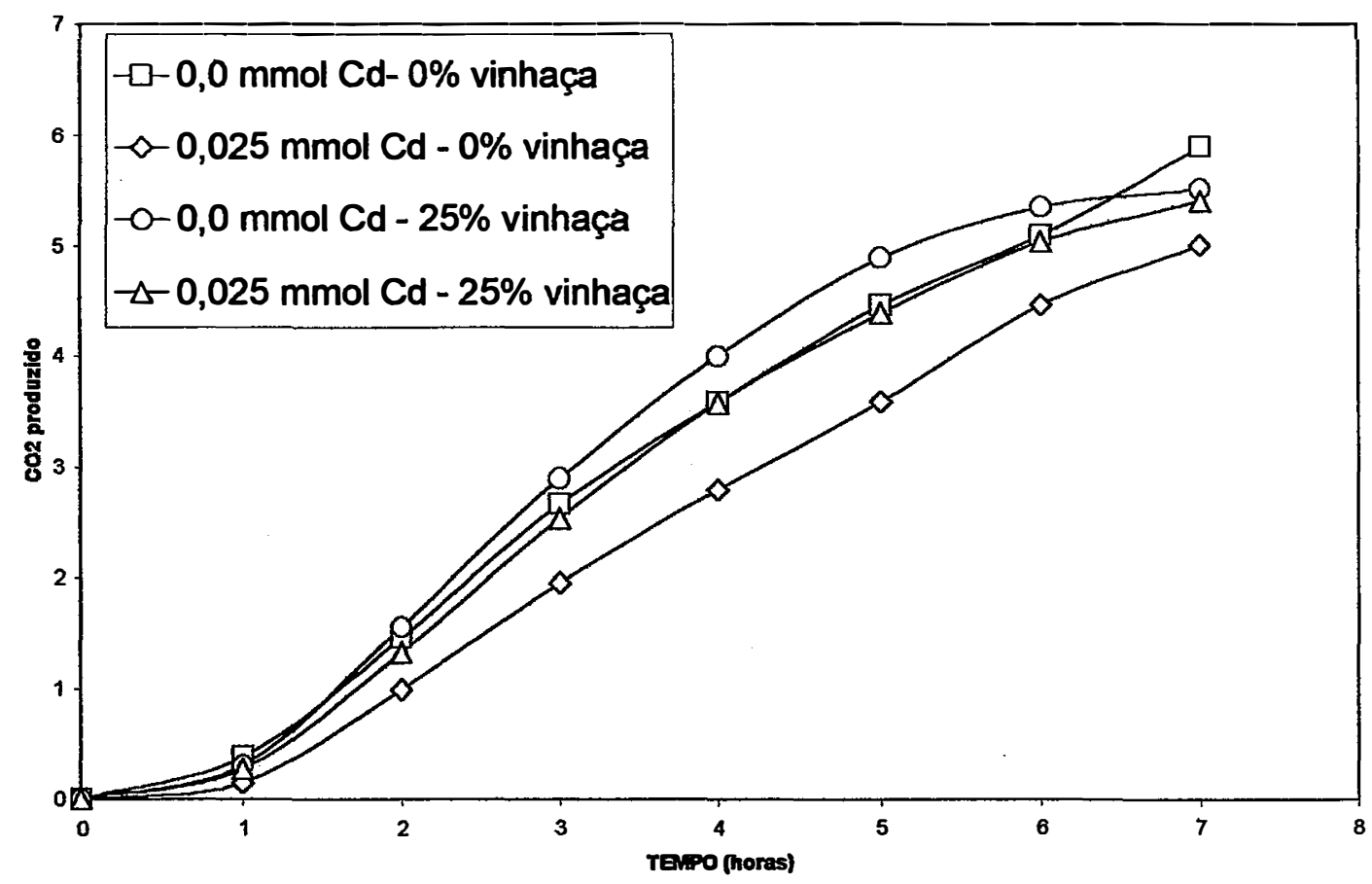

Figura 41 - Produção de $\mathrm{CO}_{2}$ durante o terceiro ciclo.



Figura 42 - Produção de $\mathrm{CO}_{2}$ durante o quarto ciclo. 


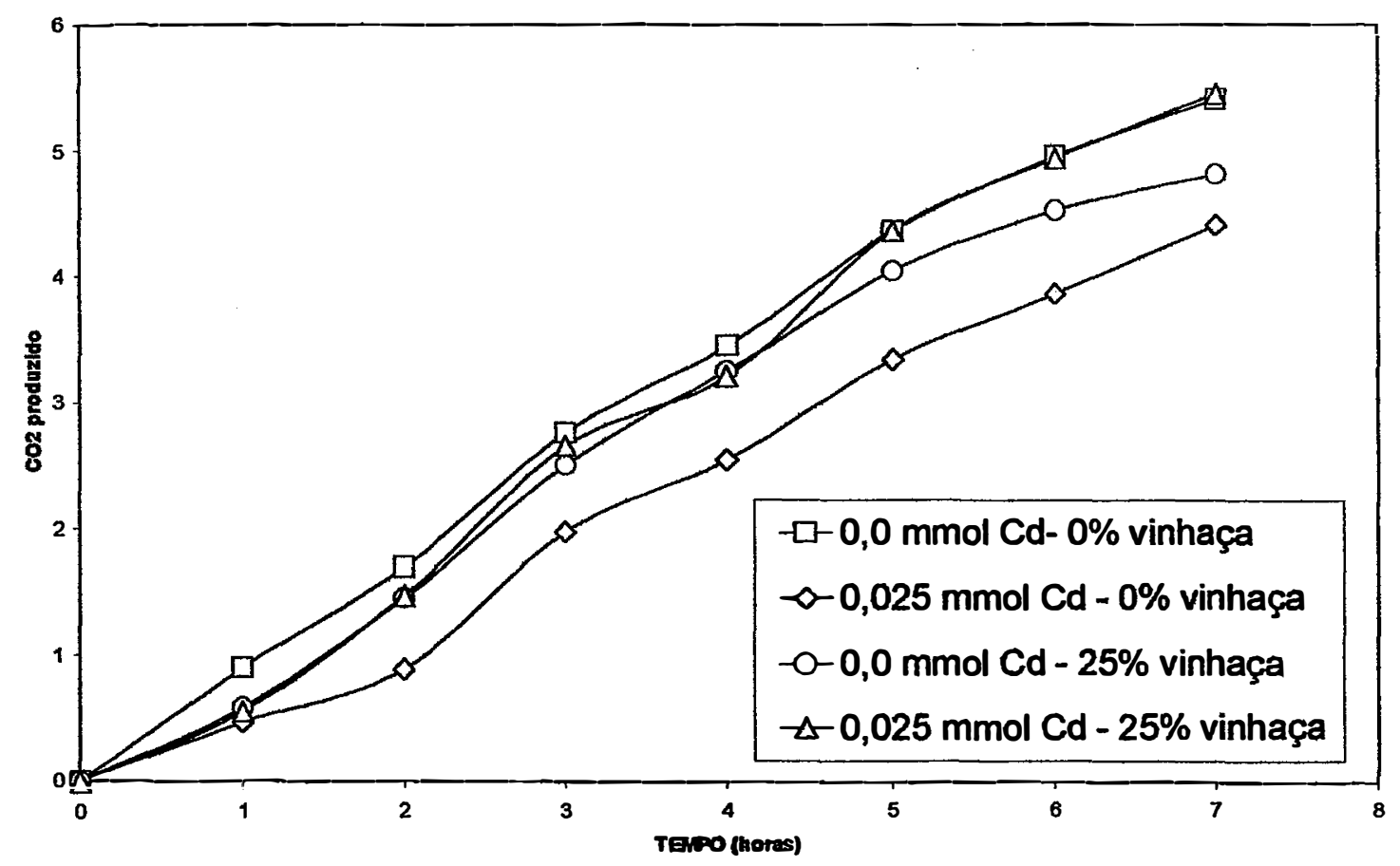

Figura 43 - Produção de $\mathrm{CO}_{2}$ durante o quinto ciclo.

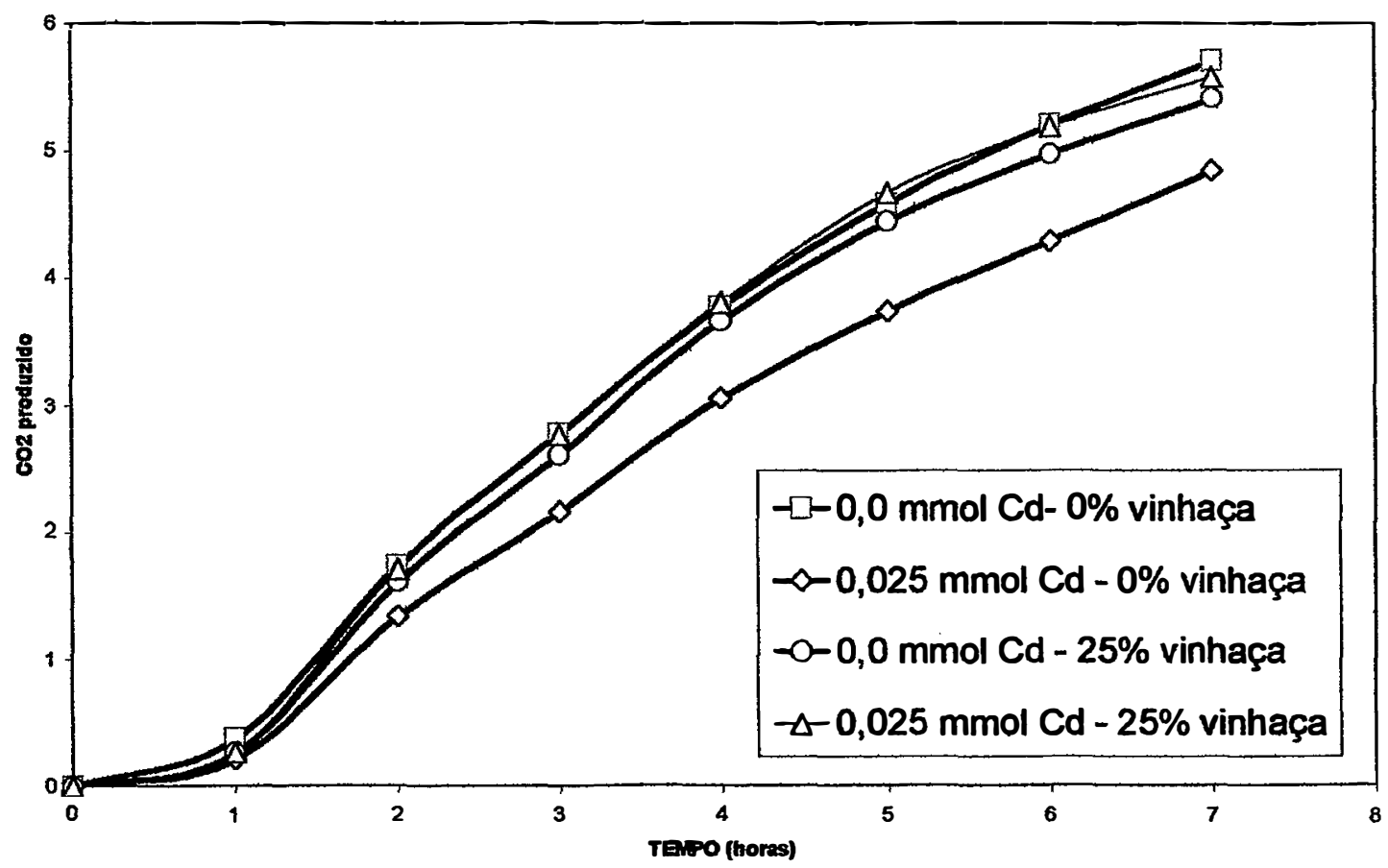

Figura 44 - Produção de $\mathrm{CO}_{2}$ durante o sexto ciclo. 
A vinhaça, na concentração de $25 \%$ atenuou totalmente o efeito tóxico de $0,025 \mathrm{mmol} \mathrm{L}^{-1}$ de cádmio no referente aos parâmetros viabilidade, formação de etanol e peso de fermento (Figuras 27, 28 e 32)

Nos tratamentos onde foi utilizada vinhaça ocorreu uma pequena redução no rendimento nos reciclos 2 e 3 , sendo que nos reciclos 4,5 e 6 os valores se igualaram aos da testemunha (Figura 26)

Comparando com a testemunha e os demais tratamentos, pode-se observar um aumento nos teores de nitrogênio e diminuição nos teores de trealose do tratamento com $0,025 \mathrm{mmol} \mathrm{L}^{-1}$ de cádmio $+0 \%$ de vinhaça (Figura 38). Este resultado está em desacordo com o que foi encontrado no ensaio 3 (Figura 19) e de acordo com o encontrado por Domingos, (1996) e Silva (1998). Os maiores teores de nitrogênio podem ser decorrência do menor acúmulo de trealose, pois a levedura, em presença de agentes estressantes utiliza suas reservas de trealose (Crowe et al., 1984), podendo ocorrer aumento nos teores de nitrogênio. Como o nitrogênio é determinado na biomassa com um teor menor de trealose, o teor de nitrogênio na biomassa total tende a aumentar A utilização das reservas de trealose poderia até mesmo explicar o aumento do teor alcóolico de vinhos oriundos da fermentação de mostos de melaço contaminados com $0,045 \mathrm{mmol} \mathrm{L}^{-1}$ de cádmio, obtidos por Domingos (1996). 


\subsection{Ensaio 5}

Nas Figuras de 45 à 49 são apresentados os resultados obtidos para taxa de viabilidade, taxa de brotamento, teor de trealose, glicogênio e acúmulo de cádmio. Nos anexos de 23 e 24 encontram-se os valores que deram origem aos gráficos apresentados nas figuras de 45 à 49 .

Ocorreu a bioacumulação de cádmio pelas leveduras ao longo dos 6 reciclos, na concentração de $0,025 \mathrm{mmol} \mathrm{L}^{-1}$, com e sem vinhaça. Porém, se observarmos os teores mensurados ao final do $1^{\circ}$ reciclo, notaremos que não houve uma variação tão significante em relação ao último reciclo (figura 47).

A bioacumulação de cádmio por leveduras nada mais é que uma tentativa de destoxificação (Ecker et al., 1986). Em um primeiro estágio, que provavelmente ocorreu durante o primeiro reciclo, houve alta produção de metaloproteínas e bioacúmulo de cádmio. Quando a capacidade produtora de metaloproteína foi excedida, começaram a aparecer os primeiros sinais de toxidade (Figura 45 e 47).

Silva (1998), e Domingos (1996), já haviam demonstrado a bioacumulação de cádmio por $S$. cerevisiae Fleishmann, em mosto de caldo-de-cana e melaço respectivamente. Os autores trabalharam somente com um reciclo, sendo os resultados obtidos muito semelhantes aos que obtemos para o primeiro ciclo. 


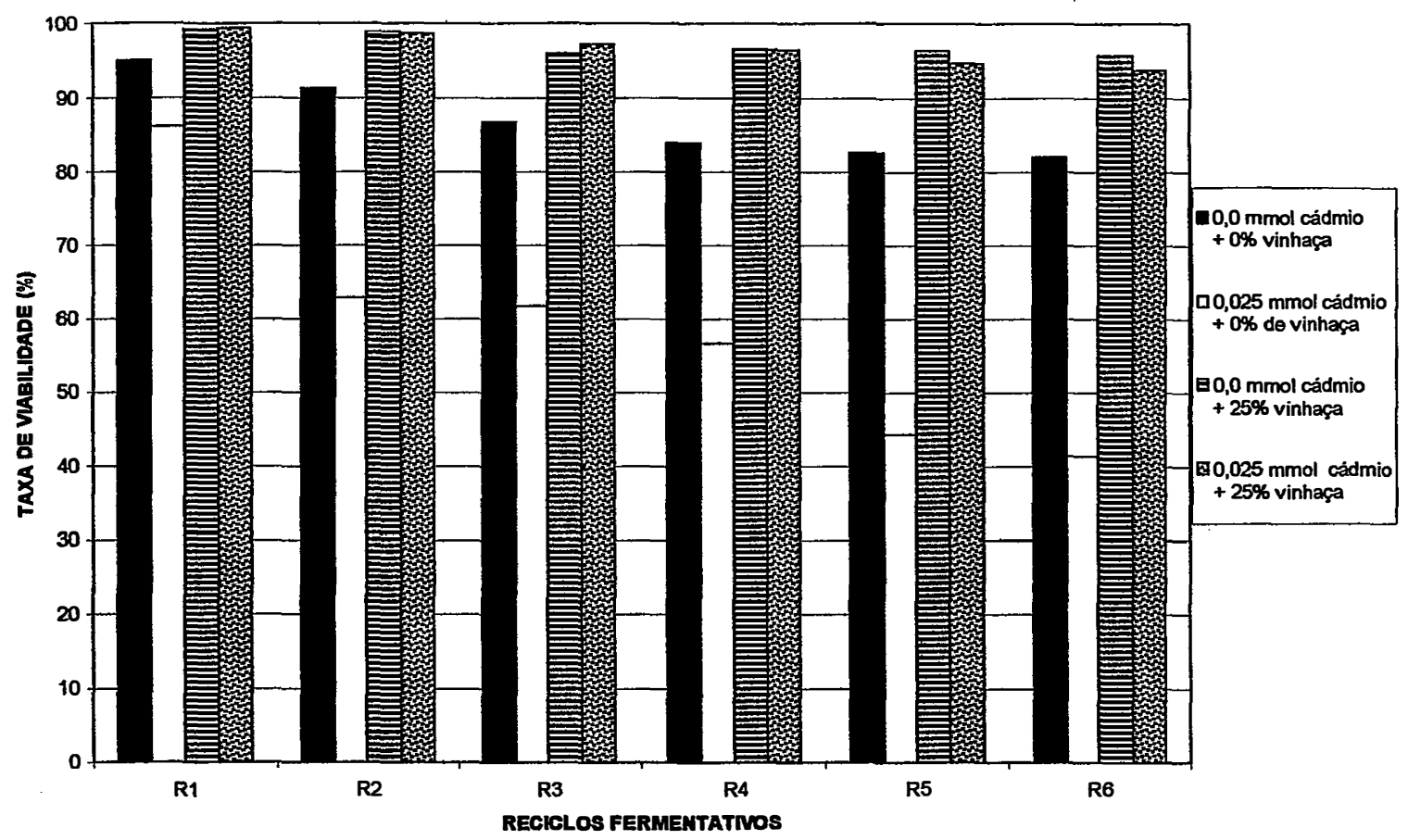

Figura 45 - Efeito de duas concentrações de cádmio e duas concentrações de vinhaça sobre a taxa de viabilidade do fermento, no transcorrer de 6 reciclos fermentativos

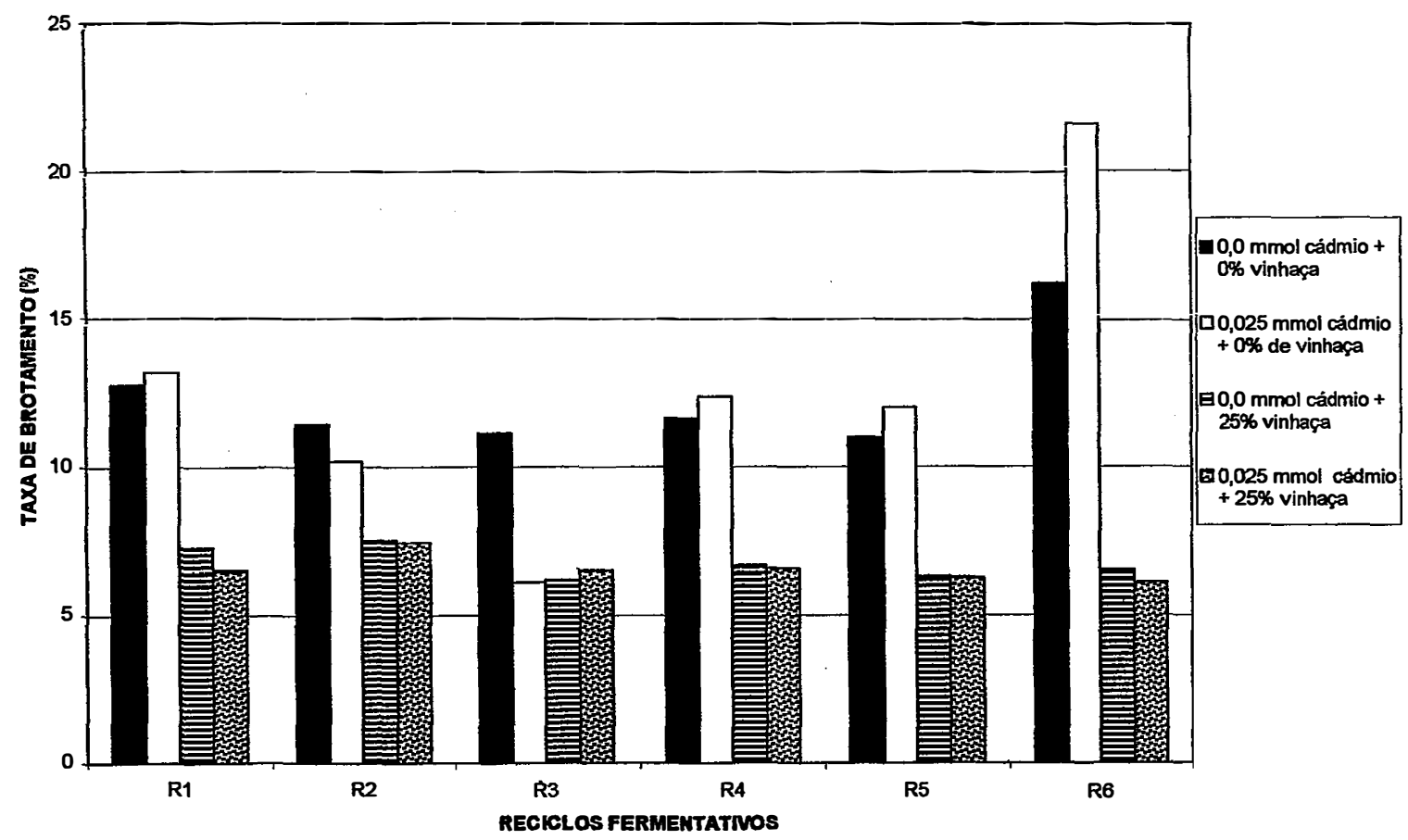

Figura 46 - Efeito de duas concentrações de cádmio e duas concentrações de vinhaça sobre a taxa de brotamento do fermento, no transcorrer de 6 reciclos fermentativos. 


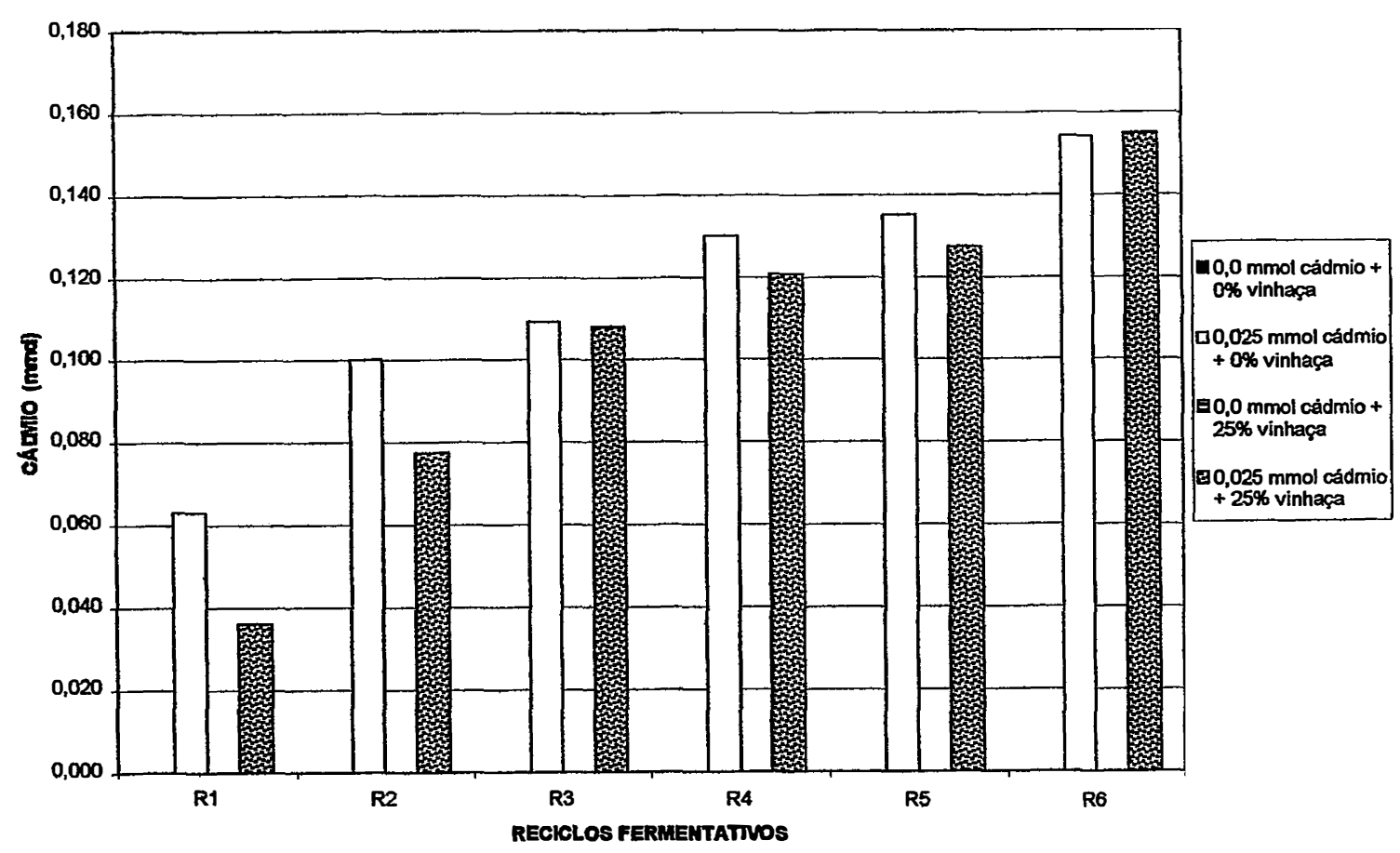

Figura 47 - Efeito de duas concentrações de cádmio e duas concentrações de vinhaça sobre a bioacumulação de cádmio pela levedura no transcorrer de 6 reciclos fermentativos.

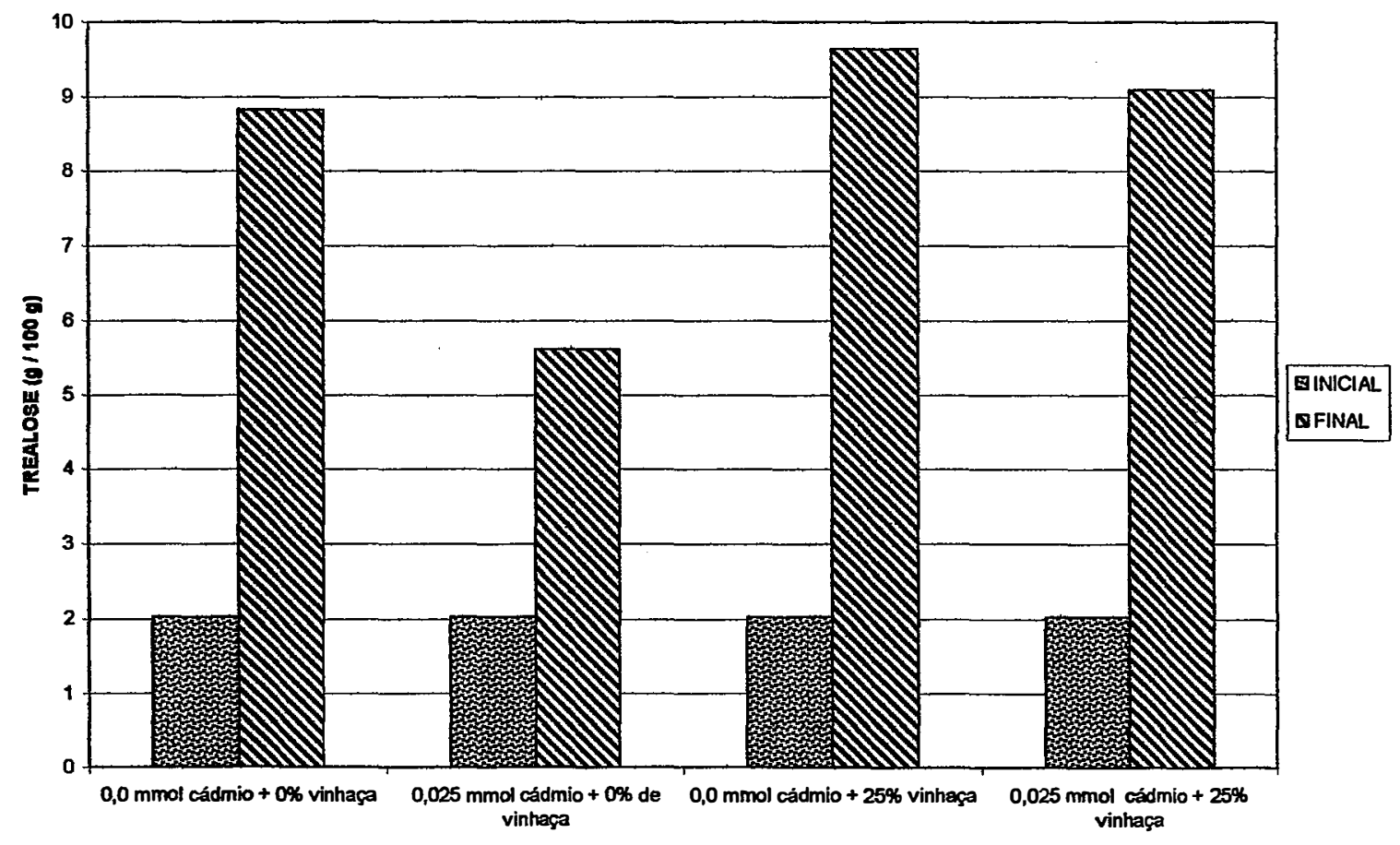

Figura 48 - Efeito de duas concentraçōes de cádmio e duas concentraçőes de vinhaça sobre os teores de trealose $\left(\mathrm{g}_{\left.100 \mathrm{~g}^{-1}\right)}\right.$ nos fermentos do ińcio do experimento $\mathrm{e}$ do final do último ciclo fermentativo. 


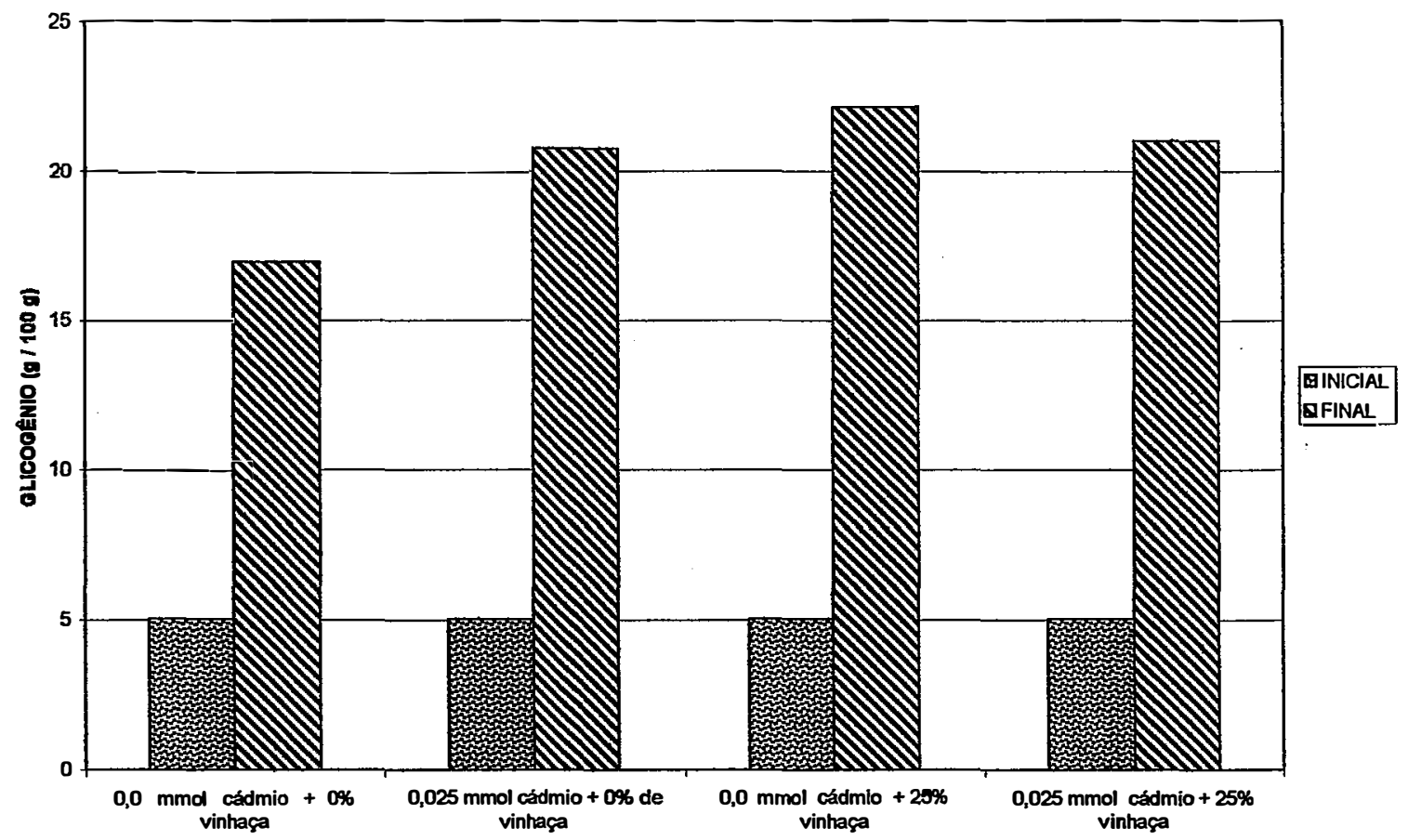

Figura 49 - Efeito de duas concentrações de cádmio e duas concentrações de vinhaça sobre os teores de

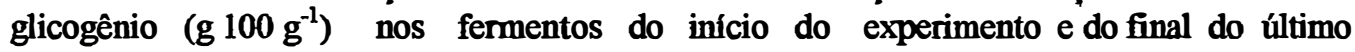
ciclo fermentativo.

Nas figuras de 50 à 55 são apresentadas as fotos feitas por MEV das leveduras submetidas aos tratamentos com cádmio e vinhaça 


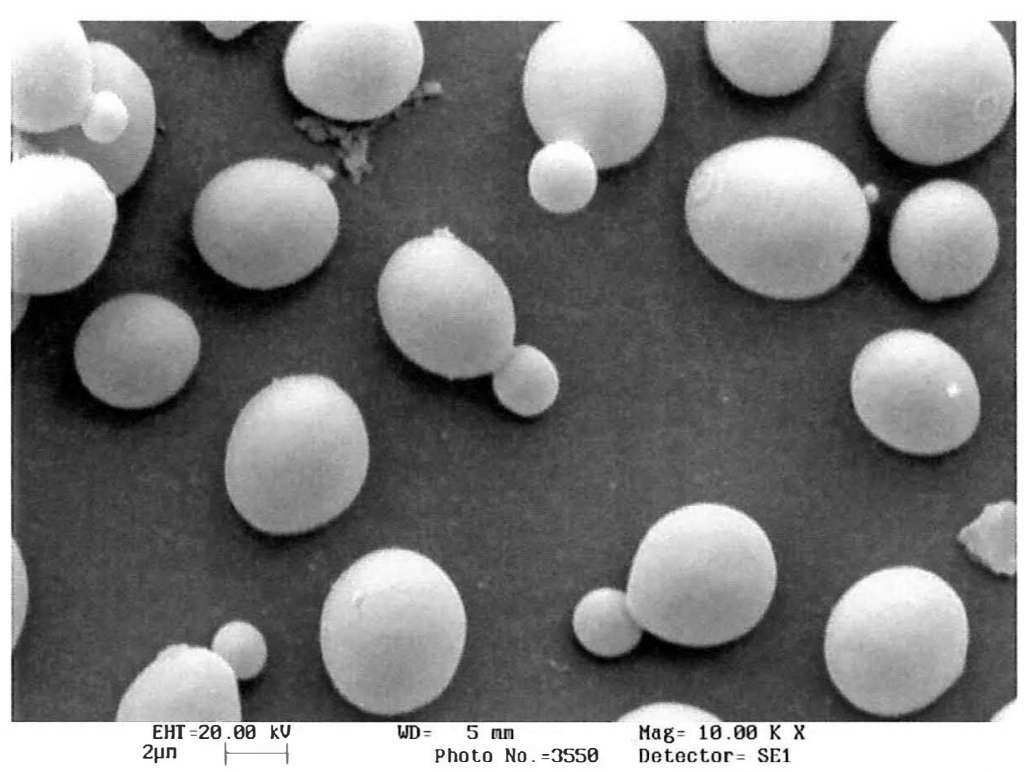

Figura 50: Levedura submetida a ao tratamento com $0,0 \mathrm{mmol} \mathrm{L}^{-1}$ de cádmio $+25 \%$ de vinhaça

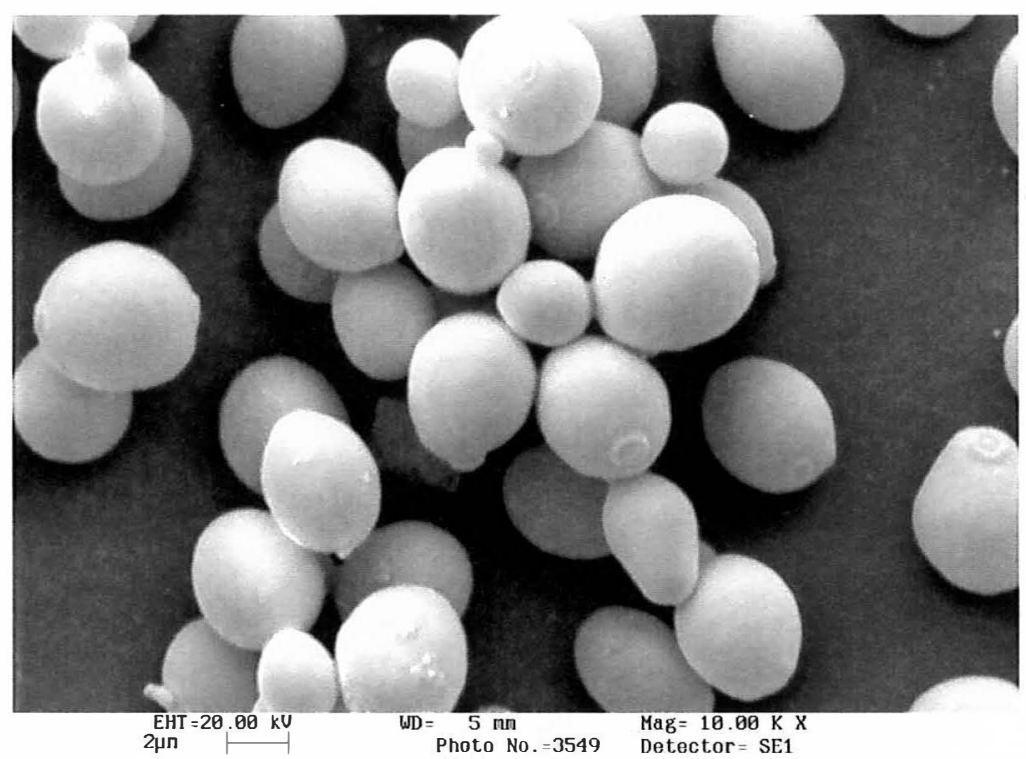

Figura 51: Leveduras submetidas ao tratamento com $0,05 \mathrm{mmol} \mathrm{L}^{-1}$ de cádmio. $+25 \%$ de vinhaça 


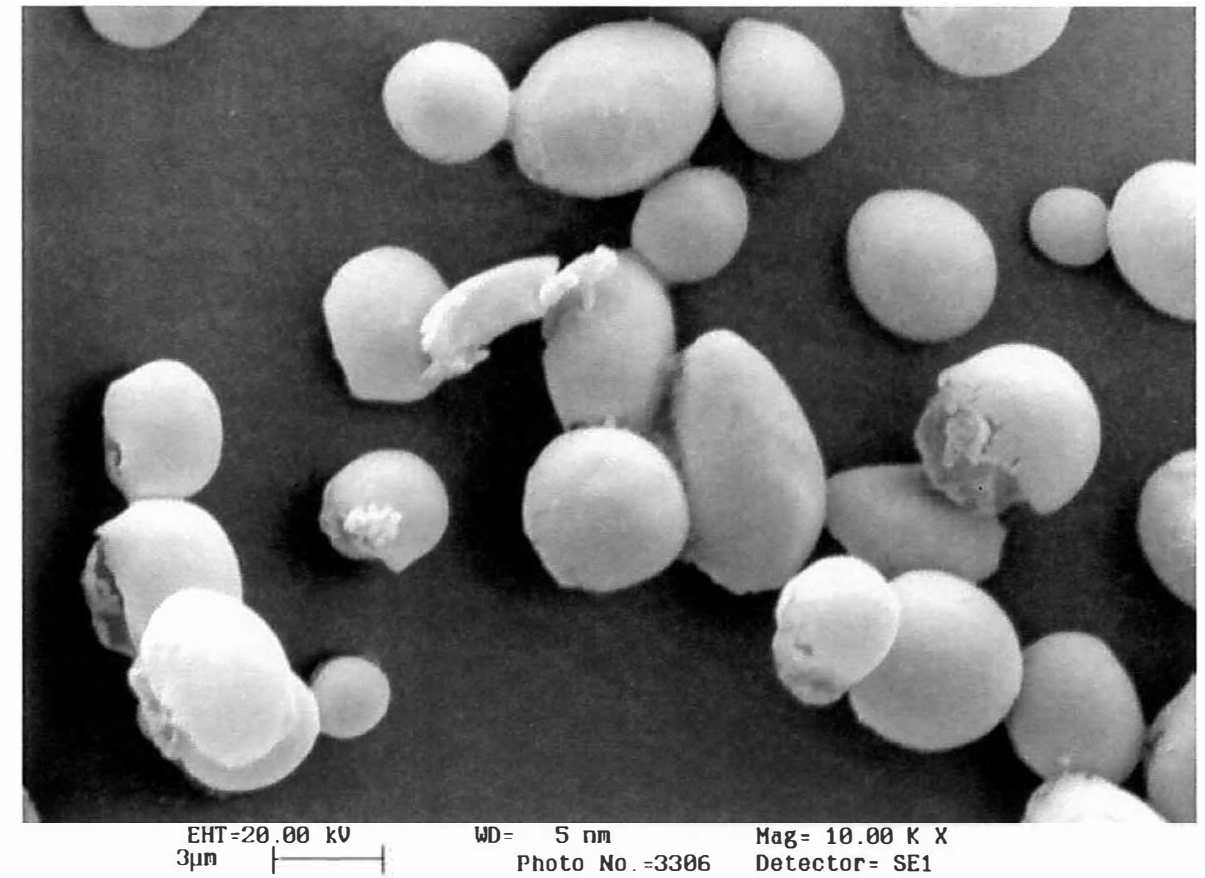

Figura 52: Leveduras submetidas ao tratamento com $0,025 \mathrm{mmol} \mathrm{L}^{-1}$ de cádmio. $+0 \%$ de vinhaça

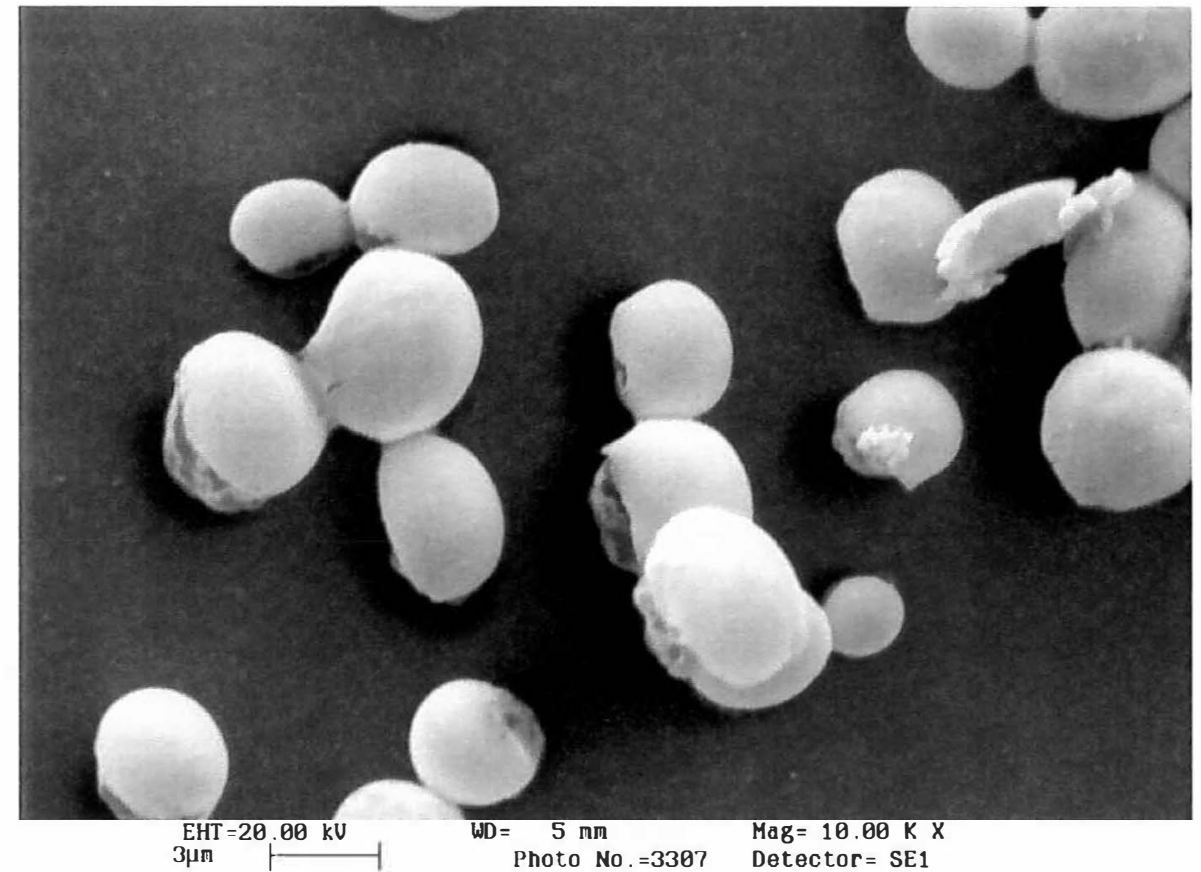

Figura 53: Leveduras submetidas ao tratamento com $0,025 \mathrm{mmol} \mathrm{L}^{-1}$ de cádmio.+ $0 \%$ de vinhaça 


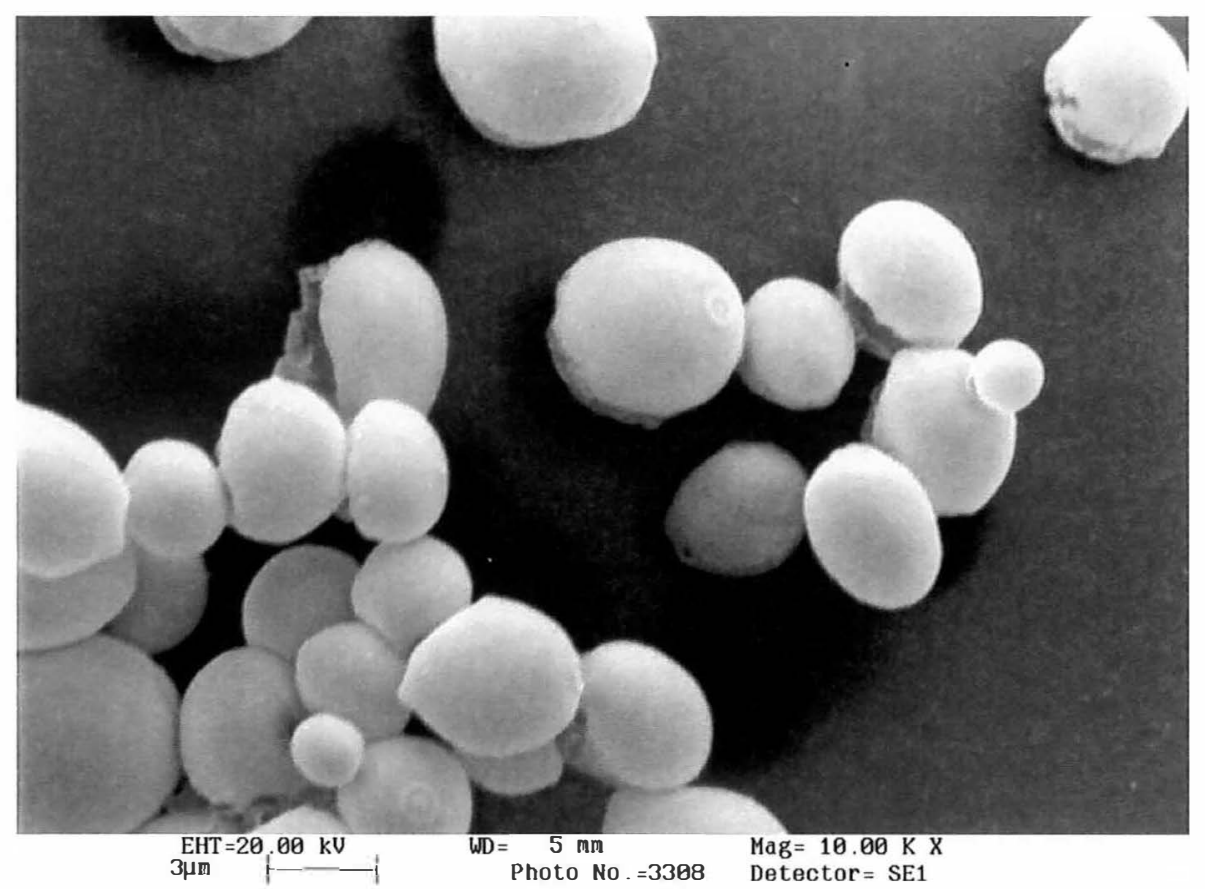

Figura 54: Leveduras submetidas ao tratamento com $0,025 \mathrm{mmol} \mathrm{L}^{-1}$ de cádmio.+ $0 \%$ de vinhaça

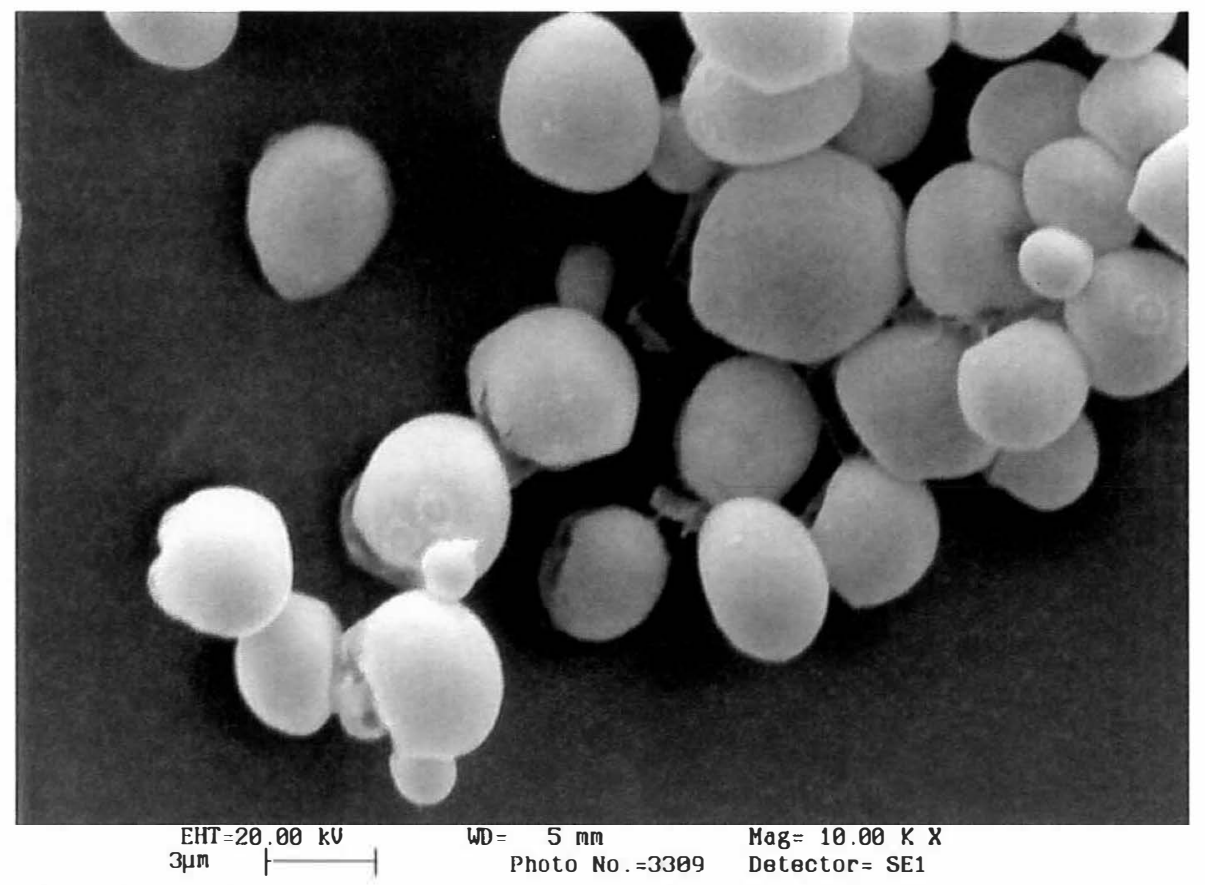

Figura 55: Leveduras submetidas ao tratamento com $0,025 \mathrm{mmol} \mathrm{L}^{-1}$ de cádmio.+ $0 \%$ de vinhaça 


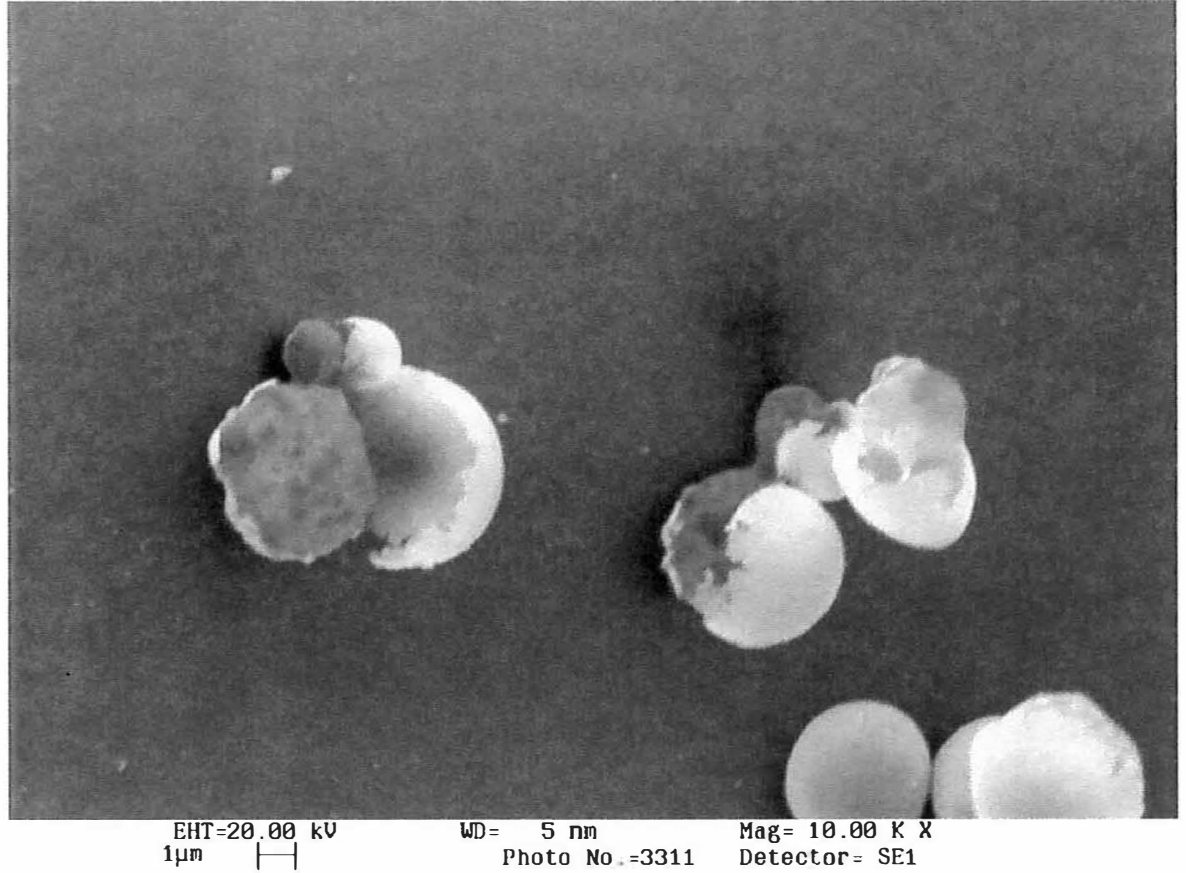

Figura 56: Leveduras submetidas ao tratamento com $0,025 \mathrm{mmol} \mathrm{L}^{-1}$ de cádmio. $+0 \%$ de vinhaça

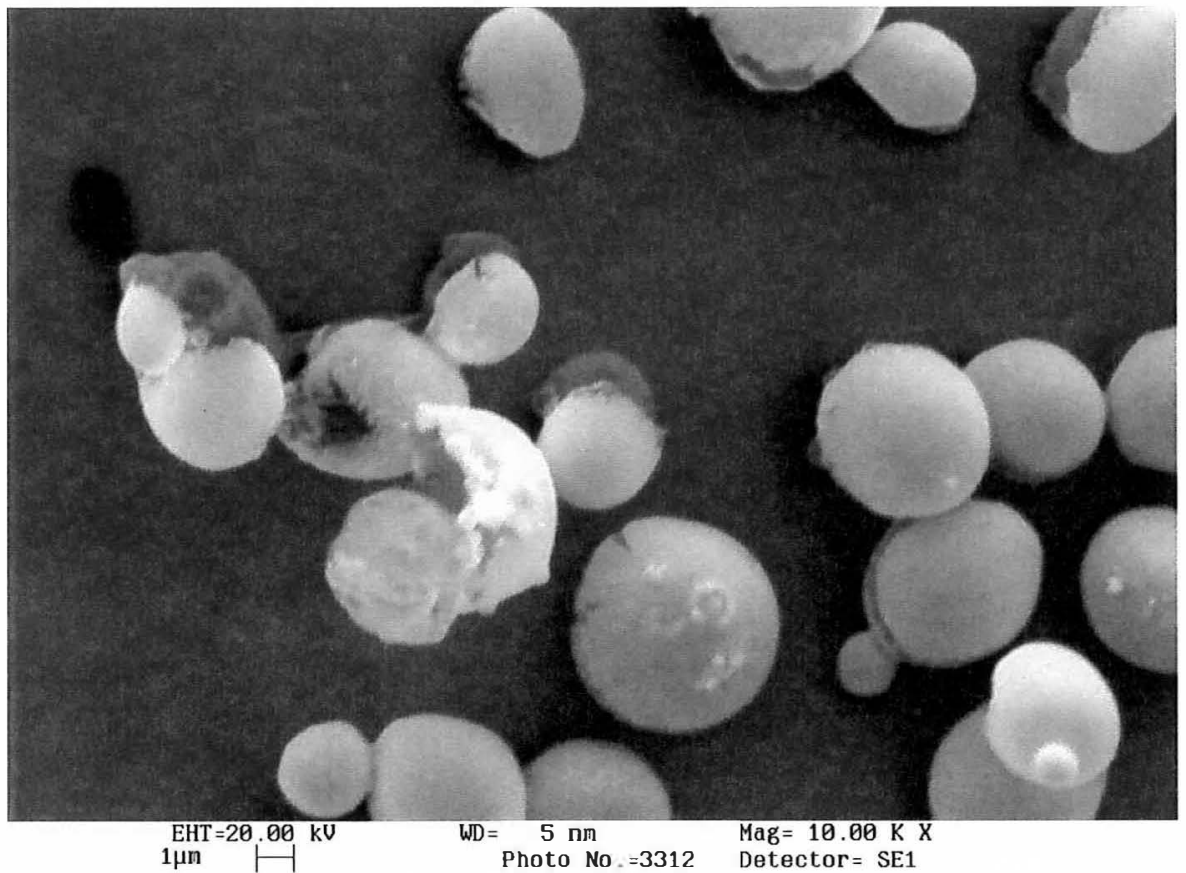

Figura 57: Leveduras submetidas ao tratamento com $0,025 \mathrm{mmol} \mathrm{L}^{-1}$ de cádmio.+ $0 \%$ de vinhaça. 
A vinhaça não impediu a bioacumulação de cádmio (Figura 47), provavelmente por não interferir no transporte ativo de cádmio e sim nos processos de biosorção, permitindo que a absorção de glicose e frutose ocorra normalmente.

As fotos realizadas no MEV mostraram claramente os danos causados pelo cádmio nas paredes celulares e membranas plasmáticas,. no tratamento de 0,025 mmol L $\mathrm{L}^{-1}$ de cádmio $+0 \%$ de vinhaça (Figuras 52 a 57 ). Nos demais tratamentos, as leveduras visualizadas estavam integras e sem qualquer dano (figuras 50 e 51).

Resultados semelhantes já haviam sido demonstrados por Albertini (1999), que submeteu células de Saccharomyces cerevisiae suspensas em água deionizada, à várias concentrações de cádmio $\left(0,045\right.$ até $\left.0,89 \mathrm{mmol} \mathrm{L} \mathrm{L}^{-1}\right) . \mathrm{O}$ autor encontrou resultados muito semelhantes aos nossos, porém os danos começaram a aparecer em concentrações acima de $0,35 \mathrm{mmol} \mathrm{L}^{-1}$ de cádmio. Provavelmente, em solução aquosa em sem glicose, as leveduras se encontram metabolicamente inativas, resistindo à concentrações mais altas de cádmio que leveduras metabolicamente ativas. Em desacordo com nossos resultados, o autor demonstra que com o aparecimento das células rompidas $\left(0,35 \mathrm{mmol} \mathrm{\textrm {L } ^ { - }}\right.$ ${ }^{1}$ ) a concentração de cádmio nas leveduras diminuiu. Infelizmente, o autor não mensurou a viabilidade das leveduras submetidas aos diferentes tratamentos, não permitindo a comparação das fotos com as taxas de viabilidade. 


\section{CONCLUSÕES}

a) O cádmio é tóxico para a levedura Saccharomyces cerevisiae, mesmo quando em baixas concentrações $\left(0,01 \mathrm{mmol} \mathrm{L}^{-1}\right)$;

b) A cepa $S$. cerevisiae PE-2 é mais tolerante ao cádmio, quando comparada com a cepa $S$. cerevisiae IZ-1904;

c) A vinhaça apresenta um discreto efeito tóxico sobre a levedura, tradurido pela redução do crescimento. Apesar disto, quando observamos os tratamentos contaminados com cádmio, notamos claramente seu efeito protetor, minimizando os efeitos deletérios do metal;

d) Os dados referentes à glicose residual, frutose residual e glicerol no vinho, parecem indicar que o mecanismo de toxicidade do cádmio para $S$. cerevisiae ocorre pela inibição do mecanismo de absorção de glicose e frutose; 
e) A levedura $S$. cerevisiae acumulou cádmio em todas as concentrações testadas, sendo que o acúmulo aumenta com a reutilização da levedura para subsequentes fermentações;

f) A vinhaça praticamente não interfere na bioacumulação de cádmio pela levedura S. cerevisiae;

g) O cádmio danificou a membrana plasmática das células de $S$. cerevisiae, terminando por causar o rompimento destas;

h) Os valores de trealose mostraram uma ótima correlação com viabilidade e crescimento da levedura, sendo este parâmetro reflete o estado fisiológico de estresse ao qual a levedura está submetida. 
ANEXOS 
ANEXO 1

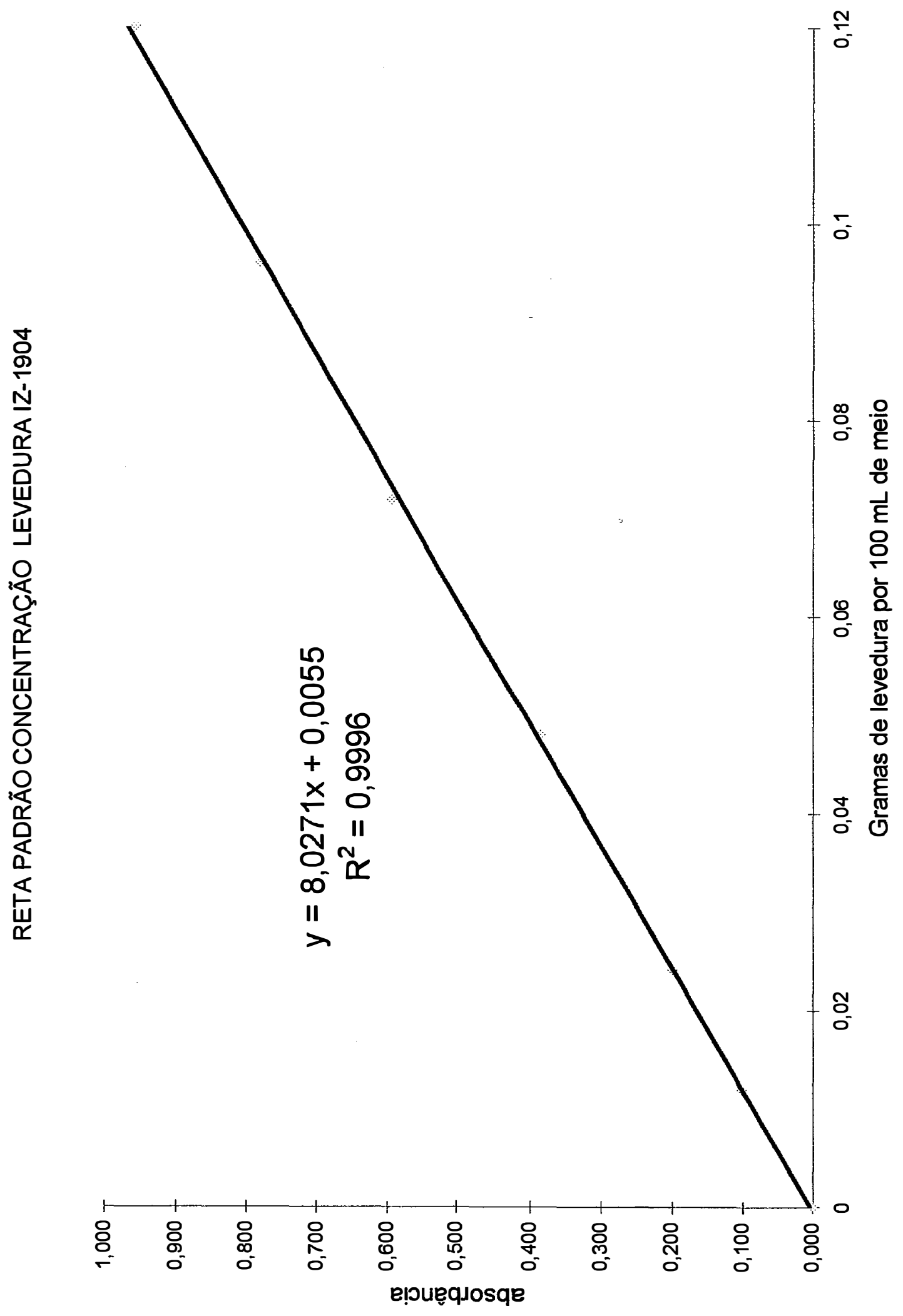




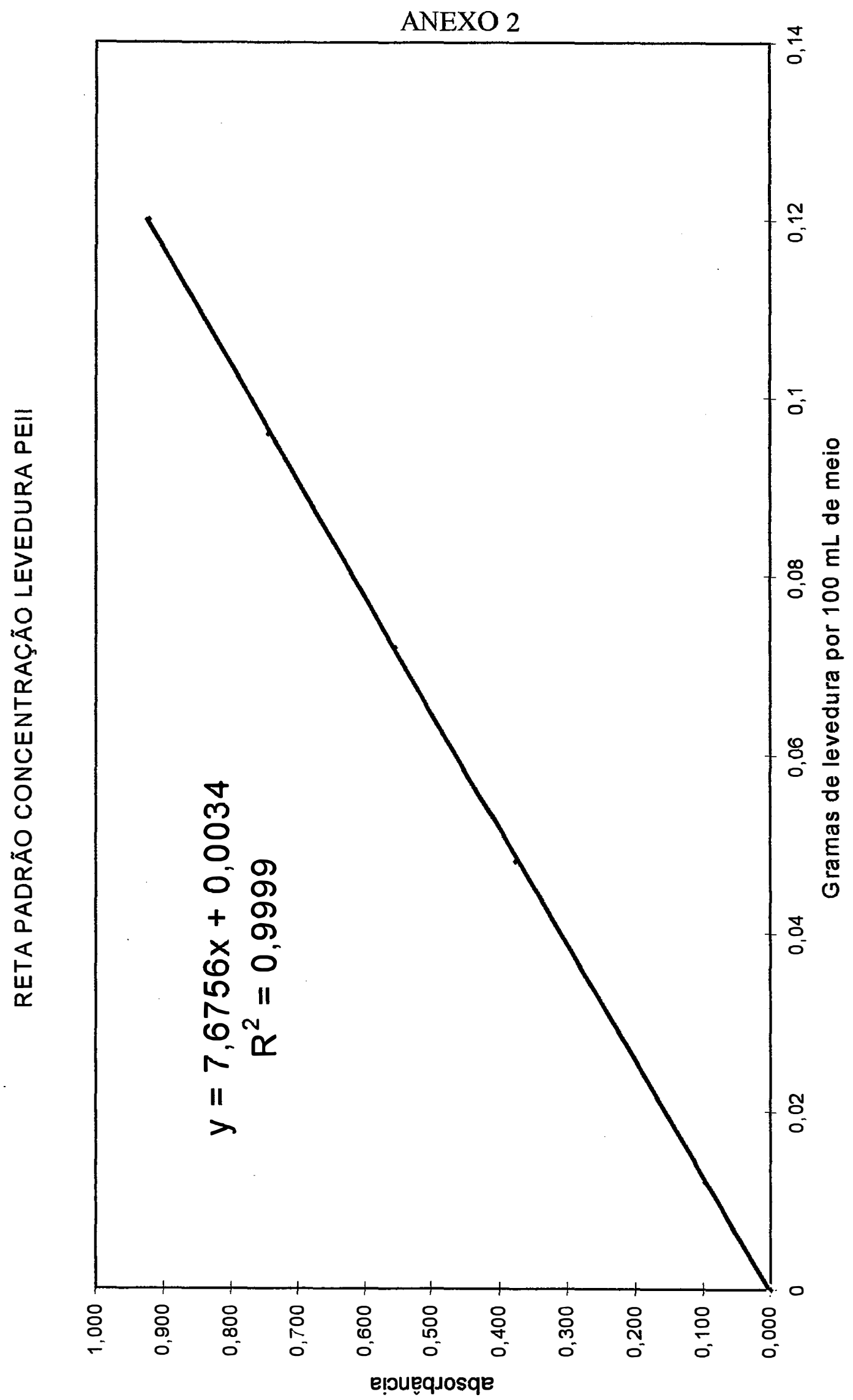



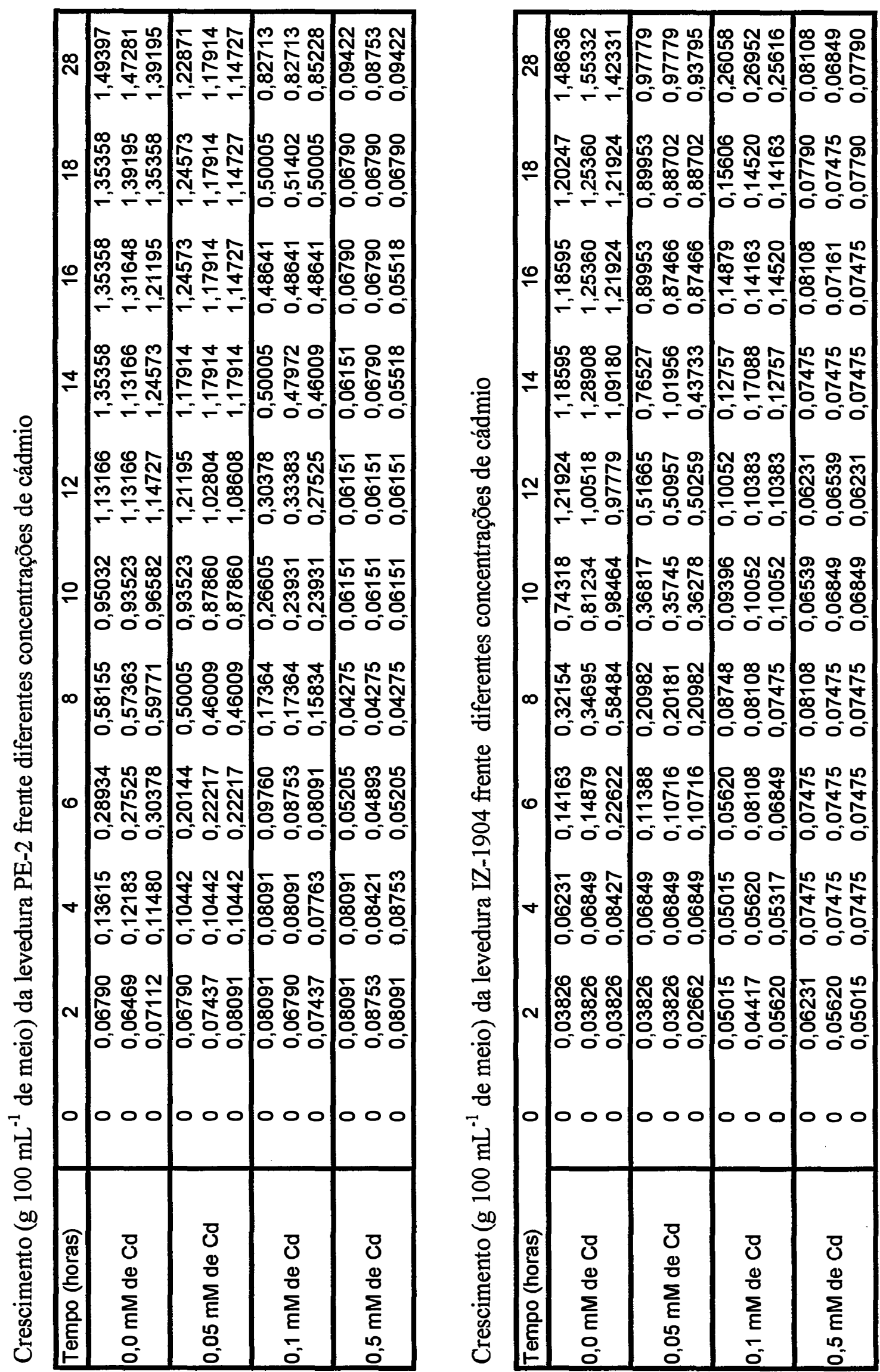
ANEXO 4

Taxa de Viabilidade (\%)

\begin{tabular}{cccccc}
\hline \hline & \multicolumn{5}{c}{ Tratamento $\left(\mathrm{Cd} \mathrm{L}^{-1}\right)$} \\
\cline { 2 - 6 } IZ-1904 & Inicial & $0,0 \mathrm{mmol}$ & $0,05 \mathrm{mmol}$ & $0,1 \mathrm{mmol}$ & $0,5 \mathrm{mmol}$ \\
\cline { 2 - 6 } PE-2 & $98,32 \mathrm{Aa}$ & $87,73 \mathrm{Aa}$ & $80,03 \mathrm{Ba}$ & $65,72 \mathrm{Ca}$ & $89,80 \mathrm{Aa}$ \\
& $99,18 \mathrm{Aa}$ & $94,74 \mathrm{Aa}$ & $86,66 \mathrm{Ba}$ & $59,86 \mathrm{Ca}$ & $86,32 \mathrm{Ba}$ \\
\hline
\end{tabular}

COEFICIENTE DE VARIAÇÃO: $\mathrm{A}=4,95 \quad \mathrm{~B}=5,94$

As médias seguidas pelas mesmas letras (maiúsculas ou minúsculas), não diferem entre sí dentro de uma mesma linha ou mesma coluna, de acordo com o teste de Tukey à $1 \%$ de significância.

Taxa de Brotamento (\%)

\begin{tabular}{cccccc}
\hline & \multicolumn{5}{c}{ Tratamento $\left(\mathrm{Cd} \mathrm{L}^{-1}\right)$} \\
\cline { 2 - 6 } IZ-1904 & Inicial & $0,0 \mathrm{mmol}$ & $0,05 \mathrm{mmol}$ & $0,1 \mathrm{mmol}$ & $0,5 \mathrm{mmol}$ \\
\cline { 2 - 6 } PE-2 & $9,22 \mathrm{Aa}$ & $13,18 \mathrm{Aa}$ & $12,95 \mathrm{Aa}$ & $11,06 \mathrm{Ab}$ & $1,60 \mathrm{Bb}$ \\
& $9,05 \mathrm{Ba}$ & $29,78 \mathrm{Ab}$ & $15,70 \mathrm{Ba}$ & $19,12 \mathrm{Aa}$ & $11,46 \mathrm{Ba}$ \\
\hline
\end{tabular}

COEFICIENTE DE VARIAÇÃO: $\mathrm{A}=14,98 \quad \mathrm{~B}=17,65$

As médias seguidas pelas mesmas letras (maiúsculas ou minúsculas), não diferem entre sí dentro de uma mesma linha ou mesima coluna, de acordo com o teste de Tukey à $1 \%$ de significância.

Teor de Trealose (\%)

\begin{tabular}{cccccc}
\hline & \multicolumn{5}{c}{ Tratamento $\left(\mathrm{Cd} \mathrm{L}^{-1}\right)$} \\
\cline { 2 - 6 } IZ-1904 & Inicial & $0,0 \mathrm{mmol}$ & $0,05 \mathrm{mmol}$ & $0,1 \mathrm{mmol}$ & $0,5 \mathrm{mmol}$ \\
\cline { 2 - 6 } PE-2 & $2,50 \mathrm{Aa}$ & $2,31 \mathrm{Aa}$ & $0,50 \mathrm{Ca}$ & $0,56 \mathrm{Ca}$ & $1,59 \mathrm{Ba}$ \\
\hline \hline
\end{tabular}

COEFICIENTE DE VARIAÇÃO: $\mathrm{A}=13,99 \quad \mathrm{~B}=11,78$

As médias seguidas pelas mesmas letras (maiúsculas ou minúsculas), não diferem entre sí dentro de uma mesma linha ou mesma coluna, de acordo com o teste de Tukey à $1 \%$ de significância.

Álcool (\%)

\begin{tabular}{ccccc}
\hline \hline & \multicolumn{4}{c}{ Tratamento $\left(\mathrm{Cd} \mathrm{L}^{-1}\right)$} \\
\cline { 2 - 5 } IZ-1904 & $0,0 \mathrm{mmol}$ & $0,05 \mathrm{mmol}$ & $0,1 \mathrm{mmol}$ & $0,5 \mathrm{mmol}$ \\
PE-2 & $1,00 \mathrm{Aa}$ & $0,88 \mathrm{Aa}$ & $0,45 \mathrm{Bb}$ & $0,00 \mathrm{Ca}$ \\
& $1,03 \mathrm{Aa}$ & $0,98 \mathrm{Aa}$ & $0,69 \mathrm{Ba}$ & $0,00 \mathrm{Ca}$ \\
\hline \hline
\end{tabular}

COEFICIENTE DE VARIAÇÃO: $\mathrm{A}=12,89 \mathrm{~B}=11,34$

As médias seguidas pelas mesmas letras (maiúsculas ou minúsculas), não diferem entre sí dentro de uma mesma linha ou mesma coluna, de acordo com o teste de Tukey à $1 \%$ de significância. 


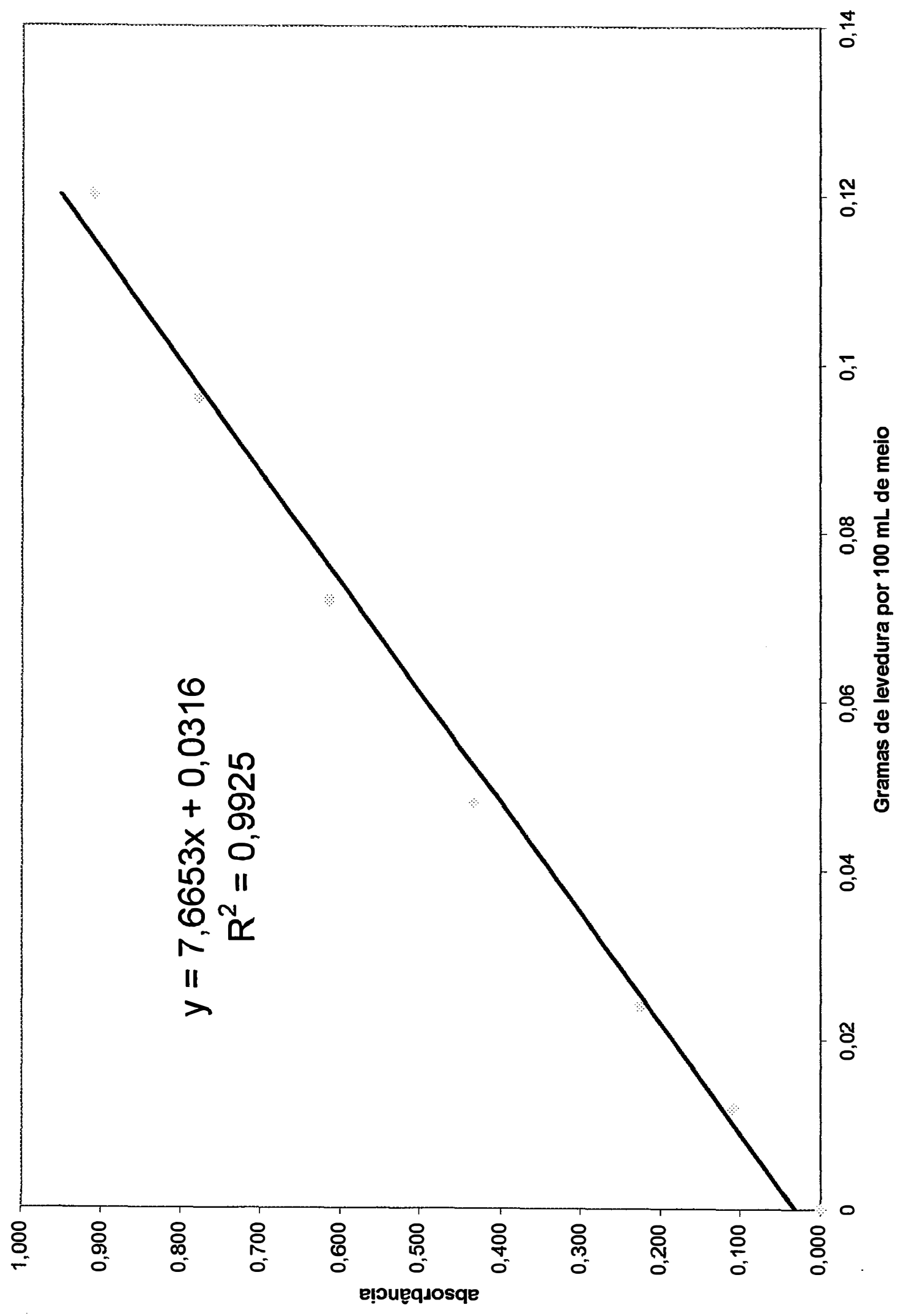


ANEXO 7

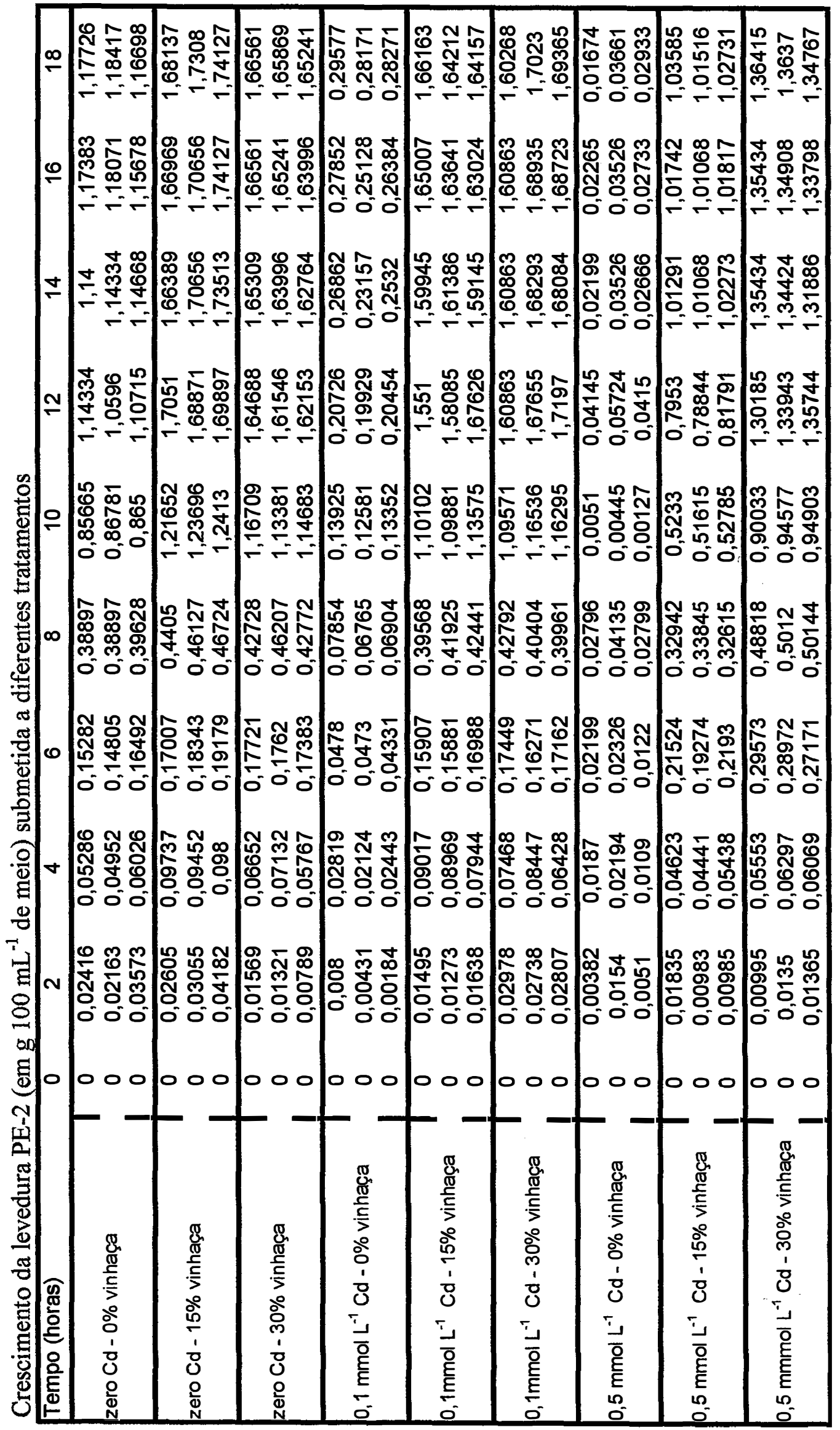


ANEXO 8

Taxa de Viabilidade (\%)

\begin{tabular}{ccccc}
\hline & \multicolumn{4}{c}{ Tratamento $\left(\mathrm{Cd} \mathrm{L}^{-1}\right)$} \\
\cline { 2 - 5 } $0 \%$ vinhaça & Inicial & $0,0 \mathrm{mmol}$ & $0,1 \mathrm{mmol}$ & $0,5 \mathrm{mmol}$ \\
\cline { 2 - 5 } $15 \%$ vinhaça & $99,74 \mathrm{Aa}$ & $99,54 \mathrm{Aa}$ & $67,40 \mathrm{Bb}$ & $0,00 \mathrm{Cb}$ \\
$30 \%$ vinhaça & $99,74 \mathrm{Aa}$ & $99,83 \mathrm{Aa}$ & $99,68 \mathrm{Aa}$ & $99,44 \mathrm{Aa}$ \\
\hline
\end{tabular}

$$
\text { COEFICIENTE DE VARIAÇÃO: } \mathrm{A}=5,67 \quad \mathrm{~B}=4,32
$$

As médias seguidas pelas mesmas letras (maiúsculas ou minúsculas), não diferem entre sí dentro de uma mesma linha ou mesma coluna, de acordo com o teste de Tukey à $1 \%$ de significância.

Taxa de Brotamento (\%)

\begin{tabular}{lcccc} 
& \multicolumn{4}{c}{ Tratamento $\left(\mathrm{Cd} \mathrm{L}^{-1}\right)$} \\
\cline { 2 - 5 } $0 \%$ vinhaça & Inicial & $0,0 \mathrm{mmol}$ & $0,1 \mathrm{mmol}$ & $0,5 \mathrm{mmol}$ \\
\cline { 2 - 5 } $15 \%$ vinhaça & $18,50 \mathrm{Aa}$ & $22,07 \mathrm{Aa}$ & $6,31 \mathrm{Bb}$ & $0,00 \mathrm{Cb}$ \\
$30 \%$ vinhaça & $18,50 \mathrm{Aba}$ & $22,71 \mathrm{Aa}$ & $16,15 \mathrm{Ba}$ & $23,11 \mathrm{Aa}$ \\
& $18,50 \mathrm{Aba}$ & $23,41 \mathrm{Aa}$ & $16,08 \mathrm{Ca}$ & $21,03 \mathrm{Aa}$ \\
\hline
\end{tabular}

COEFICIENTE DE VARIAÇÃO: $\mathrm{A}=2.34 \quad \mathrm{~B}=3,45$

As médias seguidas pelas mesmas letras (maiúsculas ou minúsculas), não diferem entre sí dentro de uma mesma linha ou mesma coluna, de acordo com o teste de Tukey à $1 \%$ de significância.

Teor de Trealose (\%)

\begin{tabular}{lcccc} 
& \multicolumn{4}{c}{ Tratamento $\left(\mathrm{Cd} \mathrm{L}^{-1}\right)$} \\
\cline { 2 - 5 } $0 \%$ vinhaça & Inicial & $0,0 \mathrm{mmol}$ & $0,1 \mathrm{mmol}$ & $0,5 \mathrm{mmol}$ \\
\cline { 2 - 5 } $15 \%$ vinhaça & $1,41 \mathrm{Aa}$ & $1,35 \mathrm{Aa}$ & $0,05 \mathrm{Bb}$ & $0,00 \mathrm{Bb}$ \\
$30 \%$ vinhaça & $1,41 \mathrm{Aa}$ & $0,48 \mathrm{Bb}$ & $0,11 \mathrm{Cb}$ & $0,40 \mathrm{Ba}$ \\
& $1,41 \mathrm{Aa}$ & $1,20 \mathrm{Aa}$ & $0,52 \mathrm{Ba}$ & $0,52 \mathrm{Ba}$ \\
\hline
\end{tabular}

COEFICIENTE DE VARIAÇÃO: $\mathrm{A}=5,67 \quad \mathrm{~B}=3,45$

As médias seguidas pelas mesmas letras (maiúsculas ou minúsculas), não diferem entre sí dentro de uma mesma linha ou mesma coluna, de acordo com o teste de Tukey à $1 \%$ de significância.

Álcool (\%)

\begin{tabular}{lccc}
\hline & \multicolumn{3}{c}{ Tratamento $\left(\mathrm{Cd} \mathrm{L}^{-1}\right)$} \\
\cline { 2 - 4 } $0 \%$ vinhaça & $0,0 \mathrm{mmol}$ & $0,1 \mathrm{mmol}$ & $0,5 \mathrm{mmol}$ \\
\cline { 2 - 4 } $15 \%$ vinhaça & $0,97 \mathrm{Aa}$ & $0,71 \mathrm{Bb}$ & $0,00 \mathrm{Cb}$ \\
$30 \%$ vinhaça & $1,03 \mathrm{Aa}$ & $1,09 \mathrm{Aa}$ & $1,06 \mathrm{Aa}$ \\
\hline \hline
\end{tabular}

COEFICIENTE DE VARIAÇÃO: $\mathrm{A}=3,42 \quad \mathrm{~B}=2,99$

As médias seguidas pelas mesmas letras (maiúsculas ou minúsculas), não díferem entre sí dentro de uma mesma linha ou mesma coluna, de acordo com o teste de Tukey à $1 \%$ de significânciA. 
ANEXO 9

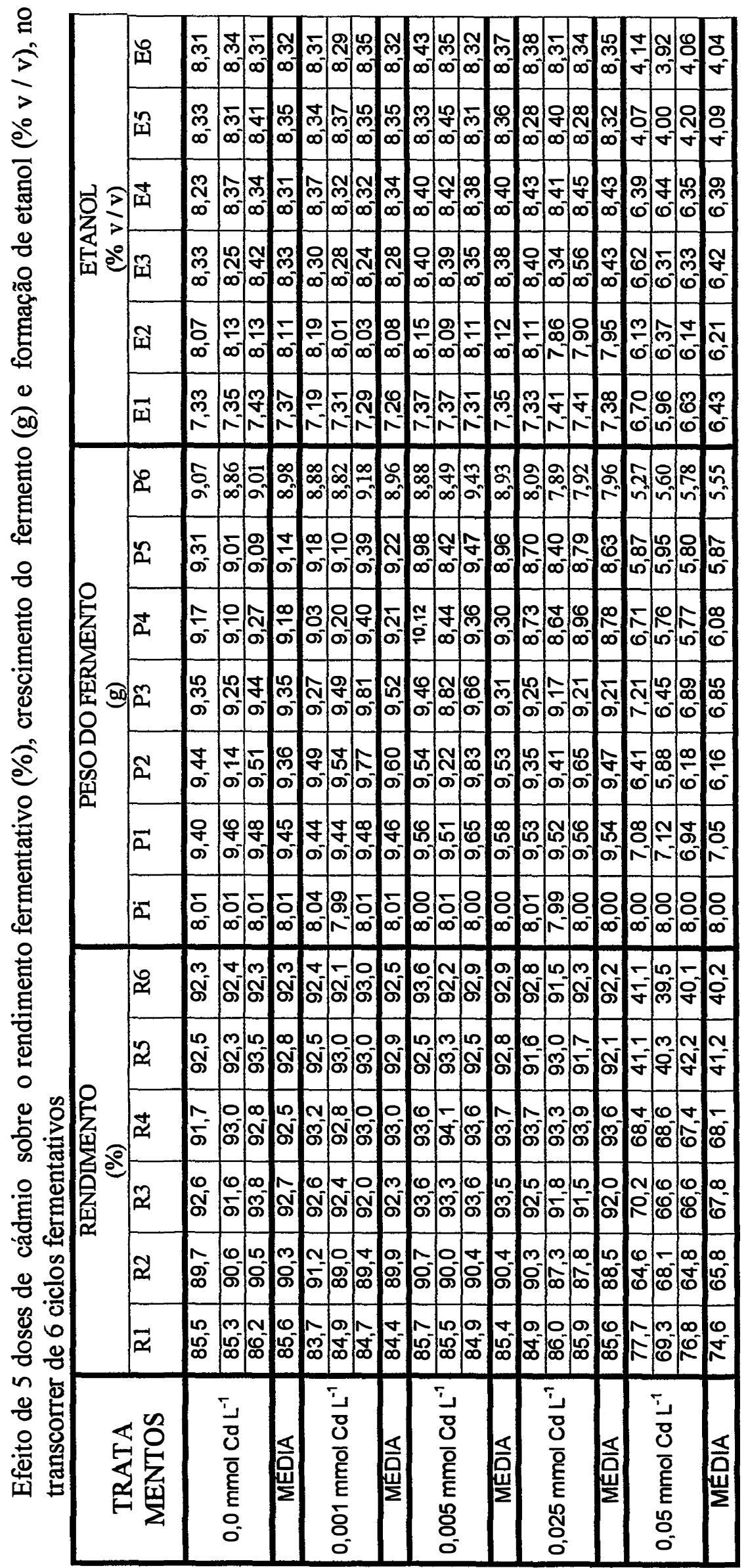


ANEXO 10

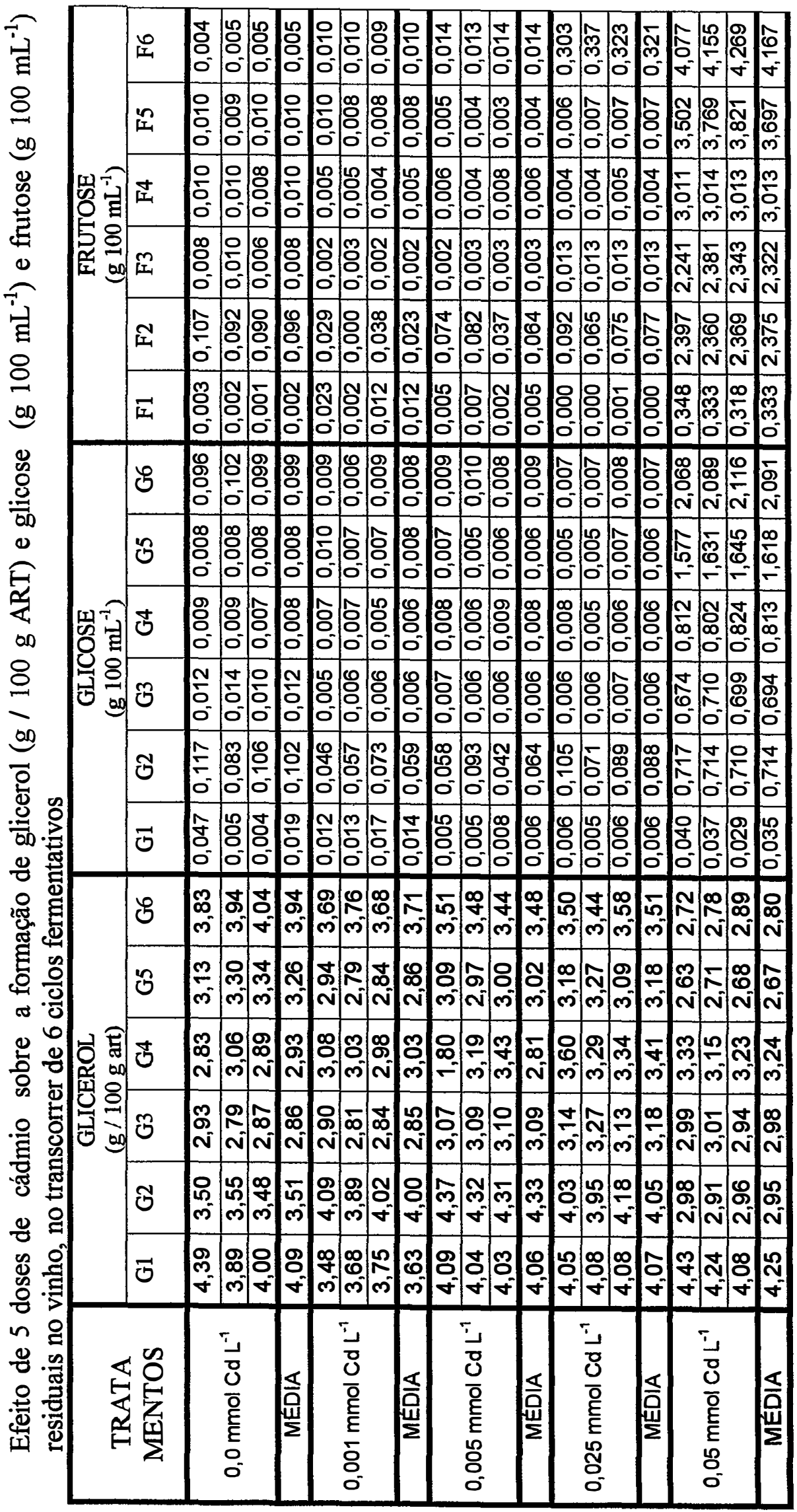


ANEXO 11

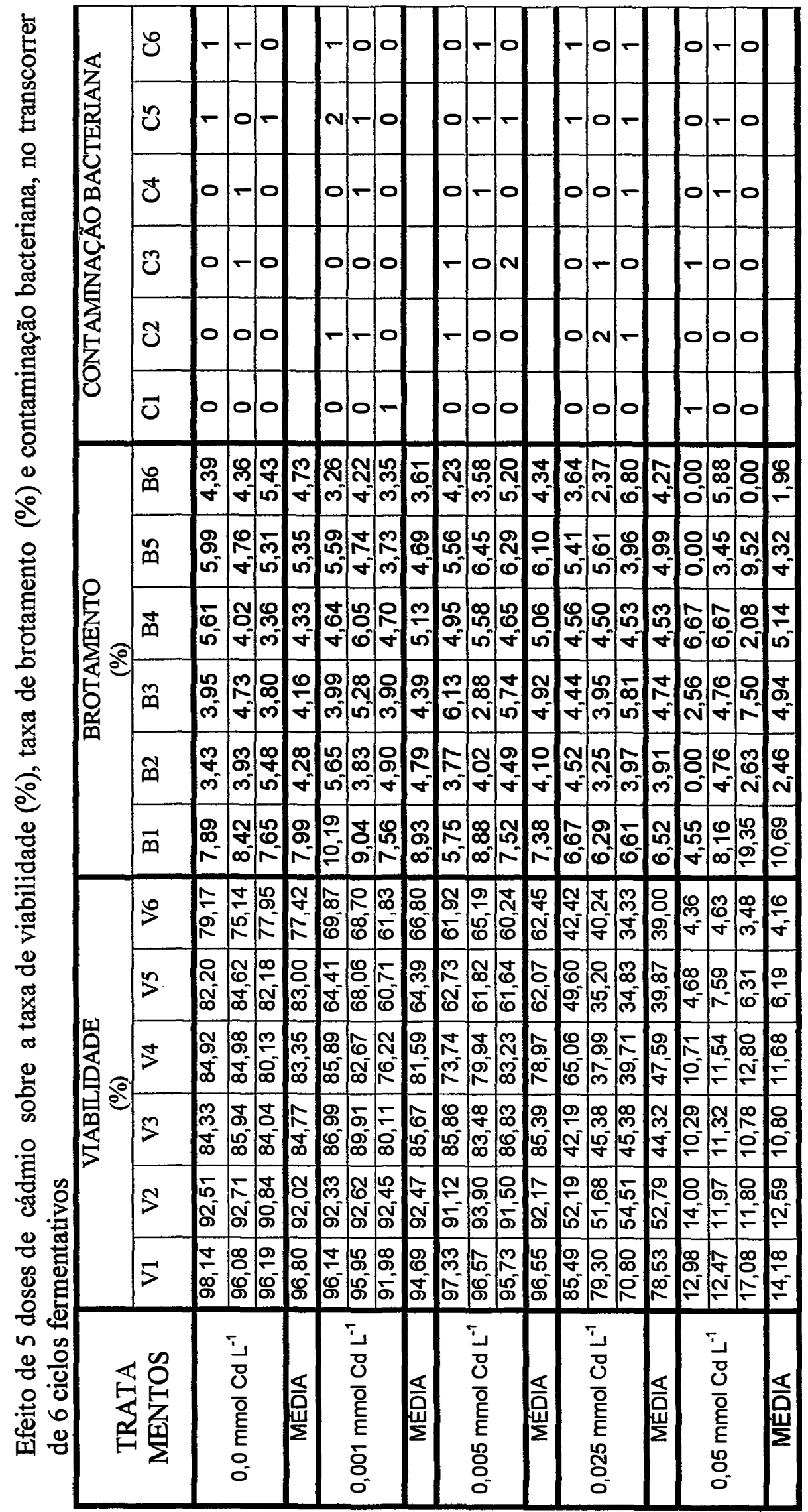


ANEXO 12

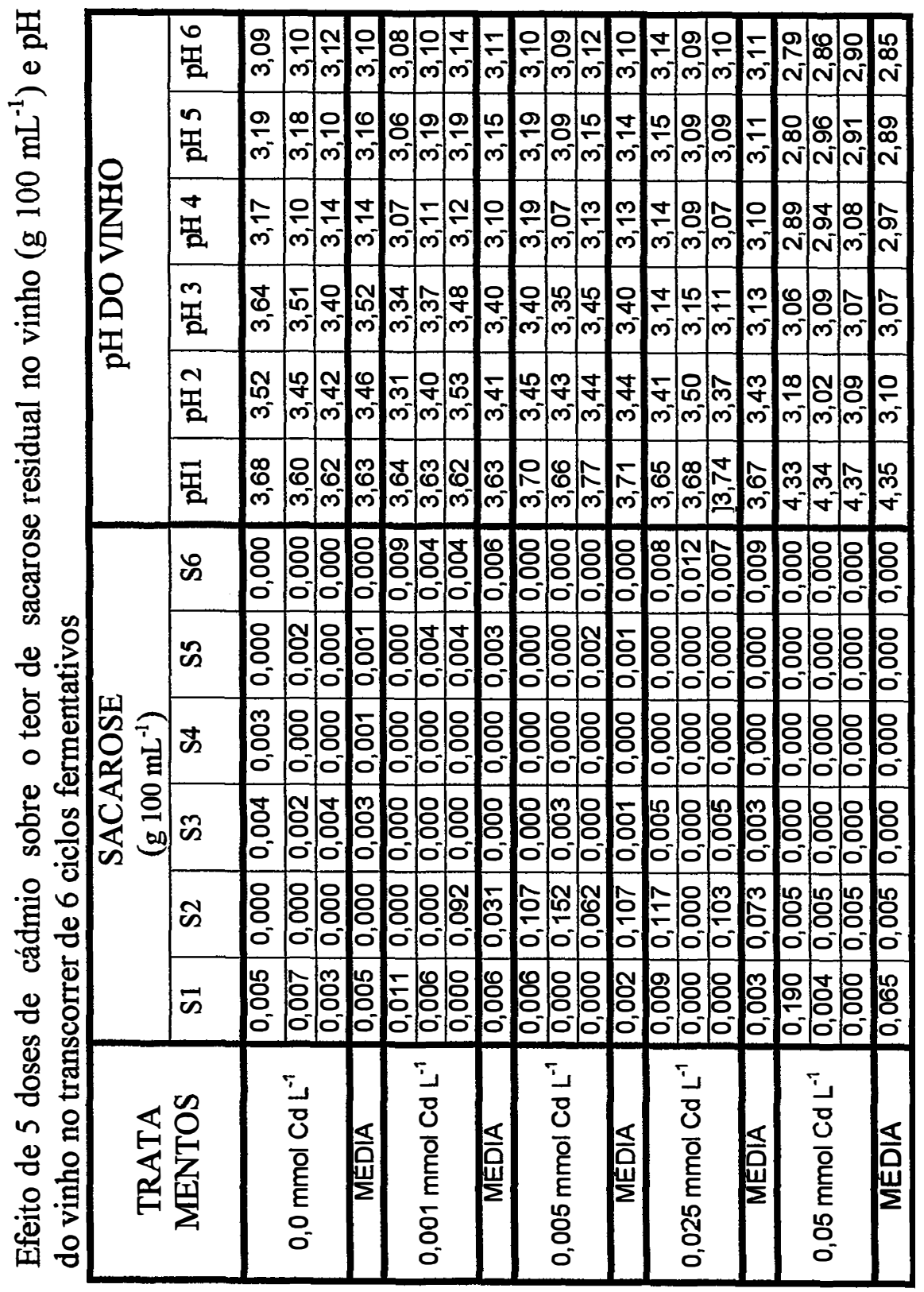




\section{ANEXO 13}

Efeito de 5 doses de cádmio sobre os teores de trealose (\% MS), glicogênio (\% MS) e nitrogênio (\% MS) iniciais e finais

\begin{tabular}{|c|c|c|c|c|c|c|}
\hline \multirow{2}{*}{$\begin{array}{l}\text { TRATA } \\
\text { MENTOS }\end{array}$} & \multicolumn{2}{|c|}{$\begin{array}{c}\text { TREALOSE } \\
\text { (\% MS) }\end{array}$} & \multicolumn{2}{|c|}{$\begin{array}{c}\text { GLICOGÊNIO } \\
\text { (\% MS) }\end{array}$} & \multicolumn{2}{|c|}{$\begin{array}{c}\text { PROTEÍNA } \\
(\% \mathrm{MS})\end{array}$} \\
\hline & INICIAL & FINAL & INICIAL & FINAL & INICIAL & FINAL \\
\hline \multirow{3}{*}{$0,0 \mathrm{mmol} \mathrm{Cd} \mathrm{L}^{-1}$} & 1,89 & 9,84 & 5,16 & 17,26 & 6,52 & 6,47 \\
\hline & 1,85 & 9,18 & 5,06 & 16,30 & 6,55 & 6,57 \\
\hline & 2,02 & 8,94 & 4,95 & 16,72 & 6,54 & 6,68 \\
\hline MÉDIA & 1,92 & 9,32 & 5,06 & 16,76 & 6,53 & 6,57 \\
\hline \multirow{3}{*}{$0,001 \mathrm{mmol} \mathrm{Cd} \mathrm{L}^{-1}$} & 1,89 & 9,34 & 5,16 & 16,84 & 6,52 & 6,43 \\
\hline & 1,85 & 9,50 & 5,06 & 16,60 & 6,55 & 6,49 \\
\hline & 2,02 & 10,37 & 4,95 & 17,09 & 6,54 & 6,50 \\
\hline MÉDIA & 1,92 & 9,74 & 5,06 & 16,84 & 6,53 & 6,47 \\
\hline \multirow{3}{*}{$0,005 \mathrm{mmol} \mathrm{Cd} \mathrm{L}^{-1}$} & 1,89 & 7,81 & 5,16 & 21,49 & 6,52 & 6,50 \\
\hline & 1,85 & 8,57 & 5,06 & 20,45 & 6,55 & 6,28 \\
\hline & 2,02 & 8,99 & 4,95 & 20,69 & 6,54 & 6,76 \\
\hline MÉDIA & 1,92 & 8,44 & 5,06 & 20,88 & 6,53 & 6,51 \\
\hline \multirow{3}{*}{$0,025 \mathrm{mmol} \mathrm{Cd} \mathrm{L}^{-1}$} & 1,89 & 4,61 & 5,16 & 24,06 & 6,52 & 6,26 \\
\hline & 1,85 & 8,06 & 5,06 & 22,24 & 6,55 & 5,55 \\
\hline & 2,02 & 5,87 & 4,95 & 22,09 & 6,54 & 6,06 \\
\hline MÉDIA & 1,92 & 5,51 & 5,06 & 22,79 & 6,53 & 5,96 \\
\hline \multirow{3}{*}{$0,05 \mathrm{mmol} \mathrm{Cd} \mathrm{L}{ }^{-1}$} & 1,89 & 1,77 & 5,16 & 24,22 & 6,52 & 4,97 \\
\hline & 1,85 & 2,97 & 5,06 & 25,88 & 6,55 & 4,50 \\
\hline & 2,02 & 2,97 & 4,95 & 24,25 & 6,54 & 4,75 \\
\hline MÉDIA & 1,92 & 1,38 & 5,06 & 24,78 & 6,53 & 4,74 \\
\hline
\end{tabular}




\section{ANEXO 14}

Efeito de 5 doses de cádmio sobre a velocidade da fermentação, estimada em produção de $\mathrm{CO}_{2}$ (em g) a cada hora, no transcorrer de 6 ciclos fermentativos.

\begin{tabular}{|c|c|c|c|c|c|c|c|c|c|}
\hline \multirow{2}{*}{ TRATAMENTOS } & \multirow[b]{2}{*}{ CICLO } & \multicolumn{8}{|c|}{ PERDA DE PESO (g) } \\
\hline & & $1 \mathrm{~h}$ & $2 \mathrm{~h}$ & $3 \mathrm{~h}$ & $4 \mathrm{~h}$ & $5 \mathrm{~h}$ & $6 \mathrm{~h}$ & $7 \mathrm{~h}$ & $20 \mathrm{~h}$ \\
\hline \multirow[t]{5}{*}{$0,0 \mathrm{mmolCd} \mathrm{L}^{-1}$} & $\begin{array}{l}1 \\
2 \\
3\end{array}$ & $\begin{array}{l}0,486 \\
0,309 \\
0,097\end{array}$ & $\begin{array}{l}1,629 \\
1,205 \\
1,332\end{array}$ & $\begin{array}{l}2,775 \\
2,074 \\
2,279\end{array}$ & $\begin{array}{l}3,771 \\
3,270 \\
3,307\end{array}$ & $\begin{array}{l}4,494 \\
3,974 \\
4,177\end{array}$ & $\begin{array}{l}4,930 \\
4,659 \\
4,764\end{array}$ & $\begin{array}{l}5,056 \\
4,887 \\
4,996\end{array}$ & $\begin{array}{l}5,329 \\
5,228 \\
5,361\end{array}$ \\
\hline & 4 & 0,377 & 1,461 & 2,518 & 3,866 & 4,647 & 5,143 & 5,693 & 6,222 \\
\hline & 5 & 0,670 & 1,902 & 2,746 & 3,932 & 4,819 & 5,428 & 5,670 & 6,345 \\
\hline & 6 & 0,532 & 1,677 & 2,598 & 3,751 & 4,344 & 5,118 & 5,691 & 6,122 \\
\hline & MÉDIA & 0,412 & 1,534 & 2,498 & 3,650 & 4,409 & 5,007 & 5,332 & 5,768 \\
\hline \multirow{7}{*}{$0,001 \mathrm{mmol} \mathrm{Cd} \mathrm{L}^{-7}$} & 1 & 0,268 & 1,321 & 2,479 & 3,419 & 3,935 & 4,342 & 4,281 & 4,412 \\
\hline & 2 & 0,243 & 1,123 & 2,024 & 3,298 & 3,998 & 4,680 & 4,895 & 5,246 \\
\hline & 3 & 0,212 & 1,422 & 2,081 & 3,486 & 4,626 & 5,258 & 5,480 & 5,886 \\
\hline & 4 & 0,639 & 1,578 & 2,503 & 3,965 & 4,733 & 5,305 & 5,818 & 6,383 \\
\hline & 5 & 0,617 & 1,772 & 2,682 & 3,880 & 4,711 & 5,366 & 5,703 & 6,117 \\
\hline & 6 & 0,546 & 1,697 & 2,648 & 3,898 & 4,671 & 5,339 & 5,752 & 6,073 \\
\hline & MÉDIA & 0,421 & 1,486 & 2,403 & 3,658 & 4,446 & 5,048 & 5,321 & 5,686 \\
\hline \multirow{7}{*}{$0,005 \mathrm{mmol} \mathrm{Cd} \mathrm{L}^{-1}$} & 1 & 0,143 & 1,192 & 2,378 & 3,438 & 4,181 & 4,810 & 4,984 & 5,294 \\
\hline & 2 & 0,099 & 0,991 & 1,877 & 3,171 & 3,898 & 4,679 & 4,947 & 5,333 \\
\hline & 3 & 0,099 & 1,230 & 1,897 & 3,430 & 4,420 & 5,071 & 5,414 & 5,736 \\
\hline & 4 & 0,553 & 1,435 & 2,782 & 3,669 & 4,364 & 4,896 & 5,449 & 6,108 \\
\hline & 5 & 0,335 & 1,810 & 2,590 & 3,825 & 4,723 & 5,307 & 5,587 & 6,187 \\
\hline & 6 & 0,431 & 1,418 & 2,388 & 3,577 & 4,236 & 5,008 & 5,564 & 6,099 \\
\hline & MEDIA & 0,277 & 1,346 & 2,319 & 3,518 & 4,304 & 4,962 & 5,324 & 5,793 \\
\hline \multirow{7}{*}{$0,025 \mathrm{mmol} \mathrm{Cd} \mathrm{L}^{-1}$} & 1 & 0,048 & 0,971 & 2,162 & 3,218 & 3,959 & 4,619 & 4,830 & 5,091 \\
\hline & 2 & 0,690 & 1,257 & 2,429 & 3,702 & 4,631 & 5,336 & 5,730 & 6,873 \\
\hline & 3 & 0,262 & 1,370 & 2,020 & 3,364 & 4,097 & 4,694 & 5,200 & 6,185 \\
\hline & 4 & 0,254 & 1,057 & 2,982 & 4,041 & 4,683 & 5,078 & 5,727 & 6,760 \\
\hline & 5 & 0,766 & 1,814 & 2,573 & 3,614 & 4,369 & 4,878 & 5,309 & 6,236 \\
\hline & 6 & 0,109 & 0,974 & 1,837 & 2,922 & 3,485 & 4,242 & 4,903 & 5,759 \\
\hline & MÉDIA & 0,355 & 1,241 & 2,334 & 3,477 & 4,204 & 4,808 & 5,283 & 6,151 \\
\hline \multirow{7}{*}{$0,05 \mathrm{mmol} \mathrm{Cd} \mathrm{L}^{-1}$} & 1 & 0,262 & 1,422 & 2,470 & 3,078 & 3,427 & 3,781 & 4,047 & 5,121 \\
\hline & 2 & 0,047 & 0,212 & 0,608 & 1,418 & 2,019 & 2,461 & 2,891 & 4,890 \\
\hline & 3 & 0,067 & 0,588 & 0,947 & 1,854 & 2,471 & 3,053 & 3,581 & 4,697 \\
\hline & 4 & 0,175 & 0,905 & 1,275 & 1,971 & 2,393 & 2,766 & 3,436 & 5,493 \\
\hline & 5 & 0,387 & 1,211 & 1,921 & 2,436 & 3,252 & 3,645 & 4,129 & 4,784 \\
\hline & 6 & 0,032 & 0,182 & 0,756 & 1,503 & 1,974 & 2,216 & 2,457 & 4,109 \\
\hline & MÉDIA & 0,162 & 0,753 & 1,330 & 2,043 & 2,589 & 2,987 & 3,424 & 4,849 \\
\hline
\end{tabular}


ANEXO 15

Rendimento fermentativo (\%)

\begin{tabular}{ccccccc}
\hline $\begin{array}{c}\text { Tratamentos } \\
\left(\text { mmol } \mathrm{Cd} \mathrm{L}^{-1}\right)\end{array}$ & $1^{\circ}$ & $2^{\circ}$ & $3^{\circ}$ & $4^{\circ}$ & $5^{\circ}$ & $6^{\circ}$ \\
\hline 0,0 & $85,6 \mathrm{Ba}$ & $90,3 \mathrm{Aa}$ & $92,7 \mathrm{Aa}$ & $92,5 \mathrm{Aa}$ & $92,8 \mathrm{Aa}$ & $92,3 \mathrm{Aa}$ \\
0,001 & $84,4 \mathrm{Ba}$ & $89,9 \mathrm{Aa}$ & $92,3 \mathrm{Aa}$ & $93,0 \mathrm{Aa}$ & $92,9 \mathrm{Aa}$ & $92,5 \mathrm{Aa}$ \\
0,005 & $85,4 \mathrm{Ba}$ & $90,4 \mathrm{Aa}$ & $93,5 \mathrm{Aa}$ & $93,7 \mathrm{Aa}$ & $92,8 \mathrm{Aa}$ & $92,9 \mathrm{Aa}$ \\
0,025 & $85,6 \mathrm{Ba}$ & $88,5 \mathrm{Aa}$ & $92,0 \mathrm{Aa}$ & $93,6 \mathrm{Aa}$ & $92,1 \mathrm{Aa}$ & $92,2 \mathrm{Aa}$ \\
0,050 & $74,6 \mathrm{Ab}$ & $65,8 \mathrm{Bb}$ & $67,8 \mathrm{Bb}$ & $68,1 \mathrm{Bb}$ & $41,2 \mathrm{Cb}$ & $40,2 \mathrm{Cb}$ \\
\hline
\end{tabular}

COEFICIENTE DE VARIAÇÃO: $\mathrm{A}=0,587 \quad \mathrm{~B}=1,458$

As médias seguidas pelas mesmas letras (maiúsculas ou minúsculas), não diferem entre sí dentro de uma mesma linha ou mesma coluna, de acordo com o teste de Tukey à $1 \%$ de significância.

Etanol (\% v/v)

\begin{tabular}{ccccccc}
\hline \multirow{2}{*}{$\begin{array}{c}\text { Tratamentos } \\
(\text { mmol Cd L }\end{array}$} & \multicolumn{7}{c}{ CICLOS FERMENTATIVOS } \\
\cline { 2 - 7 } & $1^{\circ}$ & $2^{\circ}$ & $3^{\circ}$ & $4^{\circ}$ & $5^{\circ}$ & $6^{\circ}$ \\
\hline 0,0 & $7,37 \mathrm{Ba}$ & $8,11 \mathrm{Aa}$ & $8,33 \mathrm{Aa}$ & $8,31 \mathrm{Aa}$ & $8,35 \mathrm{Aa}$ & $8,32 \mathrm{Aa}$ \\
0,001 & $7,26 \mathrm{Ba}$ & $8,08 \mathrm{Aa}$ & $8,28 \mathrm{Aa}$ & $8,34 \mathrm{Aa}$ & $8,35 \mathrm{Aa}$ & $8,32 \mathrm{Aa}$ \\
0,005 & $7,35 \mathrm{Ba}$ & $8,12 \mathrm{Aa}$ & $8,38 \mathrm{Aa}$ & $8,40 \mathrm{Aa}$ & $8,36 \mathrm{Aa}$ & $8,37 \mathrm{Aa}$ \\
0,025 & $7,38 \mathrm{Ca}$ & $7,95 \mathrm{Ba}$ & $8,43 \mathrm{Aa}$ & $8,43 \mathrm{Aa}$ & $8,32 \mathrm{Aa}$ & $8,37 \mathrm{Aa}$ \\
0,050 & $6,43 \mathrm{Ab}$ & $6,21 \mathrm{Ab}$ & $6,42 \mathrm{Ab}$ & $6,39 \mathrm{Ab}$ & $4,09 \mathrm{Bb}$ & $4,04 \mathrm{Bb}$ \\
\hline
\end{tabular}

COEFICIENTE DE VARIAÇÃO: $\mathrm{A}=0,555 \quad \mathrm{~B}=1,356$

As médias seguidas pelas mesmas letras (maiúsculas ou minúsculas), não diferem entre sí dentro de uma mesma linha ou mesma coluna, de acordo com o teste de Tukey à $1 \%$ de significância.

Peso do fermento (g)

\begin{tabular}{ccccccc}
\hline \hline \multirow{2}{*}{$\begin{array}{c}\text { Tratamentos } \\
(\mathrm{mmol} \mathrm{Cd} \mathrm{L})\end{array}$} & $1^{\circ}$ & $2^{\circ}$ & $3^{\circ}$ & $4^{\circ}$ & $5^{\circ}$ & $6^{\circ}$ \\
\hline 0,0 & $8,007 \mathrm{Ba}$ & $9,450 \mathrm{Aa}$ & $9,364 \mathrm{Aa}$ & $9,346 \mathrm{Aa}$ & $9,180 \mathrm{Aa}$ & $9,138 \mathrm{Aa}$ \\
0,001 & $8,013 \mathrm{Ba}$ & $9,455 \mathrm{Aa}$ & $9,601 \mathrm{Aa}$ & $9,524 \mathrm{Aa}$ & $9,208 \mathrm{Aa}$ & $9,219 \mathrm{Aa}$ \\
0,005 & $8,003 \mathrm{Ba}$ & $9,575 \mathrm{Aa}$ & $9,531 \mathrm{Aa}$ & $9,312 \mathrm{Aa}$ & $9,303 \mathrm{Aa}$ & $8,957 \mathrm{Aa}$ \\
0,025 & $8,000 \mathrm{Ca}$ & $9,536 \mathrm{Aa}$ & $9,473 \mathrm{Aa}$ & $9,210 \mathrm{Aba}$ & $8,778 \mathrm{Ba}$ & $8,629 \mathrm{Ba}$ \\
0,050 & $8,001 \mathrm{Aa}$ & $7,046 \mathrm{Bb}$ & $6,849 \mathrm{Bb}$ & $6,158 \mathrm{Cb}$ & $6,082 \mathrm{Cb}$ & $5,873 \mathrm{Cb}$ \\
\hline
\end{tabular}

COEFICIENTE DE VARIAÇÃO: $1,936 \quad \mathrm{~B}=2,722$

As médias seguidas pelas mesmas letras (maiúsculas ou minúsculas), não diferem entre sí dentro de uma mesma linha ou mesma coluna, de acordo com o teste de Tukey à $1 \%$ de significância. 
Taxa de Viabilidade (\%)

\begin{tabular}{ccccccc}
\hline Tratamentos & \multicolumn{7}{c}{ CICLOS FERMENTATIVOS } \\
\cline { 2 - 7 }$\left.(\mathrm{mmol} \mathrm{Cd} \mathrm{L})^{-1}\right)$ & $1^{\circ}$ & $2^{\circ}$ & $3^{\circ}$ & $4^{\circ}$ & $5^{\circ}$ & $6^{\circ}$ \\
\hline \hline 0,0 & $96,80 \mathrm{Aa}$ & $92,02 \mathrm{Aba}$ & $84,77 \mathrm{ABCa}$ & $83,35 \mathrm{Bca}$ & $83,00 \mathrm{Bca}$ & $77,42 \mathrm{Ca}$ \\
0,001 & $94,69 \mathrm{Aa}$ & $92,47 \mathrm{Aba}$ & $85,67 \mathrm{ABa}$ & $81,59 \mathrm{Ba}$ & $64,39 \mathrm{Cb}$ & $66,80 \mathrm{Cab}$ \\
0,005 & $96,55 \mathrm{Aa}$ & $92,17 \mathrm{Aa}$ & $85,39 \mathrm{ABa}$ & $78,97 \mathrm{Ba}$ & $62,07 \mathrm{Cb}$ & $62,45 \mathrm{Cb}$ \\
0,025 & $78,53 \mathrm{Ab}$ & $52,79 \mathrm{Bb}$ & $44,32 \mathrm{BCb}$ & $47,59 \mathrm{BCb}$ & $39,87 \mathrm{Cc}$ & $39,00 \mathrm{Cc}$ \\
0,050 & $14,18 \mathrm{Ac}$ & $12,59 \mathrm{Ac}$ & $10,80 \mathrm{Ac}$ & $11,68 \mathrm{Ac}$ & $6,19 \mathrm{Ad}$ & $4,16 \mathrm{Ad}$ \\
\hline
\end{tabular}

COEFICIENTE DE VARIAÇÃO: $\mathrm{A}=3,048 \quad \mathrm{~B}=6,794$

As médias seguidas pelas mesmas letras (maiúsculas ou minúsculas), não diferem entre sí dentro de uma mesma linha ou mesma coluna, de acordo com o teste de Tukey à $1 \%$ de significância.

Taxa de Brotamento (\%)

\begin{tabular}{ccccccc}
\hline \hline $\begin{array}{c}\text { Tratamentos } \\
\left(\mathrm{mmol} \mathrm{Cd} \mathrm{L} \mathrm{L}^{-1}\right)\end{array}$ & $1^{\circ}$ & $2^{\circ}$ & $3^{\circ}$ & $4^{\circ}$ & $5^{\circ}$ & $6^{\circ}$ \\
\hline 0,0 & $7,99 \mathrm{Aa}$ & $4,28 \mathrm{Aa}$ & $4,16 \mathrm{Aa}$ & $4,33 \mathrm{Aa}$ & $5,35 \mathrm{Aa}$ & $4,73 \mathrm{Aa}$ \\
0,001 & $8,93 \mathrm{Aa}$ & $4,79 \mathrm{Aa}$ & $4,39 \mathrm{Aa}$ & $5,13 \mathrm{Aa}$ & $4,69 \mathrm{Aa}$ & $3,61 \mathrm{Aa}$ \\
0,005 & $7,38 \mathrm{Aa}$ & $4,10 \mathrm{Aa}$ & $4,92 \mathrm{Aa}$ & $5,06 \mathrm{Aa}$ & $6,10 \mathrm{Aa}$ & $4,34 \mathrm{Aa}$ \\
0,025 & $6,52 \mathrm{Aa}$ & $3,91 \mathrm{Aa}$ & $4,74 \mathrm{Aa}$ & $2,03 \mathrm{Aa}$ & $4,99 \mathrm{Aa}$ & $4,27 \mathrm{Aa}$ \\
0,050 & $10,69 \mathrm{Aa}$ & $4,46 \mathrm{Aba}$ & $4,94 \mathrm{ABa}$ & $5,14 \mathrm{Aba}$ & $4,32 \mathrm{ABa}$ & $1,96 \mathrm{Bb}$ \\
\hline
\end{tabular}

COEFICIENTE DE VARIAÇÃO: $\mathrm{A}=8,705 \quad \mathrm{~B}=18,873$

As médias seguidas pelas mesmas letras (maiúsculas ou minúsculas), não diferem entre sí dentro de uma mesma linha ou mesma coluna, de acordo com o teste de Tukey à $1 \%$ de significância.

$\mathrm{pH}$ vinho

\begin{tabular}{ccccccc}
\hline \multirow{2}{*}{$\begin{array}{c}\text { Tratamentos } \\
\left.(\mathrm{mmol} \mathrm{Cd} \mathrm{L})^{-1}\right)\end{array}$} & $1^{1^{\circ}}$ & $2^{\circ}$ & $3^{\circ}$ & $4^{\circ}$ & $5^{\circ}$ & $6^{\circ}$ \\
\hline \hline 0,0 & $3,63 \mathrm{Ab}$ & $3,46 \mathrm{Aa}$ & $3,52 \mathrm{Aa}$ & $3,14 \mathrm{Ba}$ & $3,16 \mathrm{Ba}$ & $3,10 \mathrm{Ba}$ \\
0,001 & $3,63 \mathrm{Ab}$ & $3,41 \mathrm{Ba}$ & $3,40 \mathrm{Ba}$ & $3,10 \mathrm{Ca}$ & $3,15 \mathrm{Ca}$ & $3,11 \mathrm{Ca}$ \\
0,005 & $3,71 \mathrm{Ab}$ & $3,44 \mathrm{Ba}$ & $3,40 \mathrm{Ba}$ & $3,13 \mathrm{Ca}$ & $3,14 \mathrm{Ca}$ & $3,10 \mathrm{Ca}$ \\
0,025 & $3,67 \mathrm{Ab}$ & $3,43 \mathrm{Ba}$ & $3,13 \mathrm{Cb}$ & $3,10 \mathrm{Ca}$ & $3,11 \mathrm{Ca}$ & $3,11 \mathrm{Ca}$ \\
0,050 & $4,35 \mathrm{Aa}$ & $3,10 \mathrm{Bb}$ & $3,07 \mathrm{Bb}$ & $2,97 \mathrm{BCa}$ & $2,89 \mathrm{Cb}$ & $2,85 \mathrm{Cb}$ \\
\hline \hline
\end{tabular}

COEFICIENTE DE VARIAÇÃO: $\mathrm{A}=0,506 \mathrm{~B}=1,846$

As médias seguidas pelas mesmas letras (maiúsculas ou minúsculas), não diferem entre sí dentro de uma mesma linha ou mesma coluna, de acordo com o teste de Tukey à $1 \%$ de significância. 
Glicerol (g/100g ART)

\begin{tabular}{ccccccc}
\hline Tratamentos & \multicolumn{7}{c}{ CICLOS FERMENTATIVOS } \\
\cline { 2 - 7 }$($ mmol Cd L & $1^{\circ}$ & $2^{\circ}$ & $3^{\circ}$ & $4^{\circ}$ & $5^{\circ}$ & $6^{\circ}$ \\
\hline 0,0 & $4,09 \mathrm{Aa}$ & $3,51 \mathrm{Aa}$ & $2,86 \mathrm{Aa}$ & $2,93 \mathrm{Aa}$ & $3,26 \mathrm{Aa}$ & $3,94 \mathrm{Aa}$ \\
0,001 & $3,63 \mathrm{Aa}$ & $4,00 \mathrm{Aa}$ & $2,85 \mathrm{Aa}$ & $3,03 \mathrm{Aa}$ & $2,86 \mathrm{Aa}$ & $3,71 \mathrm{Aa}$ \\
0,005 & $4,06 \mathrm{Aa}$ & $4,33 \mathrm{Aba}$ & $3,09 \mathrm{Aba}$ & $2,81 \mathrm{Aba}$ & $3,02 \mathrm{Ba}$ & $3,48 \mathrm{Aba}$ \\
0,025 & $4,07 \mathrm{Aa}$ & $4,05 \mathrm{Aa}$ & $3,18 \mathrm{Aa}$ & $3,41 \mathrm{Aa}$ & $3,18 \mathrm{Aa}$ & $3,51 \mathrm{Aa}$ \\
0,050 & $4,25 \mathrm{Aa}$ & $2,95 \mathrm{Aa}$ & $2,98 \mathrm{Aa}$ & $3,24 \mathrm{Aa}$ & $2,67 \mathrm{Aa}$ & $2,80 \mathrm{Aa}$ \\
\hline
\end{tabular}

COEFICIENTE DE VARIAÇÃO: $A=5,622 \quad B=14,064$

As médias seguidas pelas mesmas letras (maiúsculas ou minúsculas), não diferem entre sí dentro de uma mesma linha ou mesma coluna, de acordo com o teste de Tukey à $1 \%$ de significância.

Glicose residual no vinho $\left(\mathrm{g} 100 \mathrm{~mL}^{-1}\right)$

\begin{tabular}{ccccccc}
\hline Tratamentos & \multicolumn{7}{c}{ CICLOS FERMENTATIVOS } \\
\cline { 2 - 7 }$(\mathrm{mmol} \mathrm{Cd} \mathrm{L})$ & $1^{\circ}$ & $2^{\circ}$ & $3^{\circ}$ & $4^{\circ}$ & $5^{\circ}$ & $6^{\circ}$ \\
\hline \hline 0,0 & $0,0187 \mathrm{Ba}$ & $0,1020 \mathrm{Ab}$ & $0,0119 \mathrm{Bb}$ & $0,0080 \mathrm{Bb}$ & $0,0079 \mathrm{Bb}$ & $0,0990 \mathrm{Ab}$ \\
0,001 & $0,0140 \mathrm{Ba}$ & $0,0587 \mathrm{Ac}$ & $0,0060 \mathrm{Bb}$ & $0,0064 \mathrm{Bb}$ & $0,0077 \mathrm{Bb}$ & $0,0080 \mathrm{Bc}$ \\
0,005 & $0,0060 \mathrm{Ba}$ & $0,0644 \mathrm{Ac}$ & $0,0062 \mathrm{Bb}$ & $0,0075 \mathrm{Bb}$ & $0,0060 \mathrm{Bb}$ & $0,0090 \mathrm{Bc}$ \\
0,025 & $0,0057 \mathrm{Ba}$ & $0,0880 \mathrm{Abc}$ & $0,0058 \mathrm{Bb}$ & $0,0063 \mathrm{Bb}$ & $0,0056 \mathrm{Bb}$ & $0,0073 \mathrm{Bc}$ \\
0,050 & $0,0353 \mathrm{Ea}$ & $0,7135 \mathrm{Da}$ & $0,6943 \mathrm{Da}$ & $0,8127 \mathrm{Ca}$ & $1,6179 \mathrm{Ba}$ & $2,0910 \mathrm{Aa}$ \\
\hline
\end{tabular}

COEFICIENTE DE VARIAÇÃO: $\mathrm{A}=2,148 \quad \mathrm{~B}=5,846$

As médias seguidas pelas mesmas letras (maiúsculas ou minúsculas), não diferem entre sí dentro de uma mesma linha ou mesma coluna, de acordo com o teste de Tukey à $1 \%$ de significância.

Frutose residual no vinho $\left(\mathrm{g} 100 \mathrm{~mL}^{-1}\right)$

\begin{tabular}{ccccccc}
\hline \multirow{2}{*}{$\begin{array}{c}\text { Tratamentos } \\
(\text { mmol Cd L }\end{array}$} & $1^{\circ}$ & $2^{\circ}$ & $3^{\circ}$ & $4^{\circ}$ & $5^{\circ}$ & $6^{\circ}$ \\
\hline 0,0 & $0,0020 \mathrm{Ab}$ & $0,0962 \mathrm{Ab}$ & $0,0078 \mathrm{Ab}$ & $0,0096 \mathrm{Ab}$ & $0,0097 \mathrm{Ab}$ & $0,0047 \mathrm{Ac}$ \\
0,001 & $0,0123 \mathrm{Ab}$ & $0,0225 \mathrm{Ab}$ & $0,0024 \mathrm{Ab}$ & $0,0045 \mathrm{Ab}$ & $0,0083 \mathrm{Ab}$ & $0,0097 \mathrm{Ac}$ \\
0,005 & $0,0047 \mathrm{Ab}$ & $0,0643 \mathrm{Ab}$ & $0,0026 \mathrm{Ab}$ & $0,0060 \mathrm{Ab}$ & $0,0039 \mathrm{Ab}$ & $0,0137 \mathrm{Ac}$ \\
0,025 & $0,0003 \mathrm{Bb}$ & $0,0773 \mathrm{Bb}$ & $0,0130 \mathrm{Bb}$ & $0,0045 \mathrm{Bb}$ & $0,0069 \mathrm{Bb}$ & $0,3210 \mathrm{Ab}$ \\
0,050 & $0,3330 \mathrm{Ea}$ & $2,3752 \mathrm{Da}$ & $2,3216 \mathrm{Da}$ & $3,0127 \mathrm{Ca}$ & $3,6972 \mathrm{Ba}$ & $4,1670 \mathrm{Aa}$ \\
\hline
\end{tabular}

COEFICIENTE DE VARIAÇÃO: $\mathrm{A}=3,191 \quad \mathrm{~B}=7,326$

As médias seguidas pelas mesmas letras (maiúsculas ou minúculas), não diferem entre sí dentro de uma mesma linha ou mesma coluna, de acordo com o teste de Tukey à $1 \%$ de significância. 
Teor residual de sacarose no vinho $\left(\% \mathrm{~g} 100 \mathrm{~mL}^{-1}\right)$

\begin{tabular}{|c|c|c|c|c|c|c|}
\hline \multirow{2}{*}{$\begin{array}{l}\text { Tratamentos } \\
\left(\mathrm{mmol} \mathrm{Cd} \mathrm{L}^{-1}\right)\end{array}$} & \multicolumn{6}{|c|}{ CICLOS FERMENTATIVOS } \\
\hline & $1^{\circ}$ & $2^{\circ}$ & $3^{\circ}$ & $4^{\circ}$ & $5^{\circ}$ & $6^{\circ}$ \\
\hline 0,0 &, $0050 A a$ & 000 & 0032 & 0010 &, 0007 &, $0000 \mathrm{Aa}$ \\
\hline & a & b & $0,00 c$ & a & 0,002 & $\mathrm{Aa}$ \\
\hline & $0,0020 \mathrm{Ba}$ & $0,1070 \mathrm{Aa}$ & $0,0009 \mathrm{Ba}$ & $0,0000 \mathrm{Ba}$ & $0,0006 \mathrm{Ba}$ & $0,0000 \mathrm{Ba}$ \\
\hline 0 & 0030Aa & 0,0734Aab & 0,0034Aa & $0,0000 A a$ & $0,0000 A a$ & $0,0090 \mathrm{Aa}$ \\
\hline 0,050 & $0,0647 \mathrm{Aa}$ & $0,0047 A b$ & $0,0000 A a$ & $0,0000 A a$ & $0,0000 A a$ & $0,0000 A a$ \\
\hline
\end{tabular}

\section{COEFICIENTE DE VARIAÇÃ̃: $21,219 \quad \mathrm{~B}=21,695$}

As médias seguidas pelas mesmas letras (maińsculas ou minúculas), não diferem entre sí dentro de uma mesma linha ou mesma coluna, de acordo com o teste de Tukey à $1 \%$ de significância.

Teor inicial e final de glicogênio (\% MS), trealose (\% MS) e nitrogênio (\% MS)

\begin{tabular}{cccc}
\hline $\begin{array}{c}\text { Tratamentos } \\
\text { mmol Cd L }^{-1}\end{array}$ & $\begin{array}{c}\text { Glicogênio } \\
(\%)\end{array}$ & $\begin{array}{c}\text { Trealose } \\
(\%)\end{array}$ & $\begin{array}{c}\text { Nitrogênio } \\
(\%)\end{array}$ \\
\hline \hline Inicial & $5,06 \mathrm{~b}$ & $1,92 \mathrm{c}$ & $6,53 \mathrm{a}$ \\
0,0 & $16,76 \mathrm{a}$ & $9,32 \mathrm{a}$ & $6,57 \mathrm{a}$ \\
0,001 & $16,94 \mathrm{a}$ & $9,74 \mathrm{a}$ & $6,47 \mathrm{a}$ \\
0,005 & $20,88 \mathrm{a}$ & $8,44 \mathrm{a}$ & $6,51 \mathrm{a}$ \\
0,025 & $22,79 \mathrm{a}$ & $5,51 \mathrm{~b}$ & $5,96 \mathrm{a}$ \\
0,050 & $24,78 \mathrm{a}$ & $1,38 \mathrm{c}$ & $4,74 \mathrm{~b}$ \\
\hline \hline Coeficiente de variação (\%) & 10,11 & 4,23 & 1,92
\end{tabular}

As médias seguidas pelas mesmas letras, não diferem entre sí dentro de uma mesma coluna, de acordo com 0 teste de Tukey à $1 \%$ de significância. 


\begin{tabular}{|c|c|c|c|c|c|c|c|c|c|c|c|c|c|c|c|}
\hline \multirow{6}{*}{ 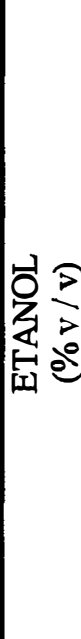 } & 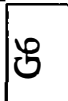 & $\left|\begin{array}{c}2 \\
\infty \\
\infty\end{array}\right|$ & 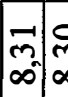 & & 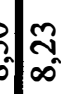 & & $\mid \begin{array}{l}\lambda \\
\infty\end{array}$ & $\begin{array}{l}0 \\
\text { N. } \\
\infty\end{array}$ & $\left|\begin{array}{c}\vec{n} \\
\infty\end{array}\right|$ & $\begin{array}{c}m \\
m \\
\infty\end{array} \mid$ & \begin{tabular}{c|c}
$\hat{\lambda}$ & 0 \\
$\infty$ & 0
\end{tabular} & & $\begin{array}{l}\stackrel{+}{n} \\
\infty^{0}\end{array}$ & & 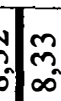 \\
\hline & 0 & $\left|\begin{array}{c}8 \\
+ \\
\infty\end{array}\right|$ & $\left|\begin{array}{c}m \\
m \\
\infty\end{array}\right|$ & $\begin{array}{c}0 \\
\overbrace{0}^{\circ} \\
0\end{array}$ & \begin{tabular}{l|l} 
s. \\
\end{tabular} & $\begin{array}{c}m \\
+\infty \\
\infty\end{array}$ & $\mid \begin{array}{c}\vec{\infty} \\
\mathbf{\infty}_{\infty}\end{array}$ & $\begin{array}{c}a \\
\infty \\
\infty\end{array}$ & & 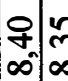 & \begin{tabular}{c|c}
$n$ \\
$m$ \\
$\infty$ & \\
$\infty$ & \\
\end{tabular} & & 常: & & $\hat{b}_{0}^{0}$ \\
\hline & 志 & 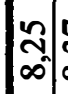 & 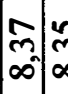 & $\overbrace{\infty}^{n}$ & $\overbrace{0}^{\circ}$ & {$\left[\begin{array}{c}\mathbb{2} \\
\infty \\
\infty\end{array}\right.$} & $\underset{\infty}{m}$ & {$\left[\begin{array}{l}n \\
2 \\
\infty\end{array}\right]$} & & $\underset{\infty}{\infty} \mid \underset{\alpha}{\alpha}$ & & & ר్ & $\underbrace{\infty}_{-1}$ & : \\
\hline & $\tilde{0}$ & $\left|\begin{array}{c}2 \\
m \\
\infty\end{array}\right|$ & \begin{tabular}{|c|c|c|c|}
- & $w$ \\
$\infty$ & $\alpha$
\end{tabular} & 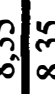 & $\begin{array}{c}\hat{m} \\
\infty \\
\infty\end{array}$ & $\mid \begin{array}{l}7 \\
⿱ \\
\infty\end{array}$ & $\mid \begin{array}{c}\infty \\
m \\
\infty\end{array}$ & $\begin{array}{c}8 \\
+\infty \\
\infty\end{array}$ & $\left|\begin{array}{c}m \\
m \\
\infty\end{array}\right|$ & $\begin{array}{c}- \\
\infty \\
\infty\end{array} \mid \stackrel{\alpha}{\alpha}$ & & & רै. & $0^{\circ} \mid 0$ & $\overbrace{0}$ \\
\hline & ㅇ & స్| & 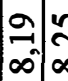 & 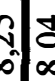 & مֵ & $\delta_{\infty}$ & 2 & $\infty$ & $\mid$ & হু & $\begin{array}{c}m \\
\sigma^{\prime}\end{array}$ & & S: & 0 & $=\delta_{\infty}$ \\
\hline & $\overrightarrow{0}$ & $\begin{array}{l}\infty \\
\infty \\
\sim\end{array}$ & $\mid$\begin{tabular}{l|l}
$\infty$ & \multicolumn{2}{c}{} \\
-1
\end{tabular} & $\mathbb{B}^{8}$ & $\underbrace{2}$ & & $\mid \begin{array}{l}\infty \\
\infty\end{array}$ & 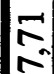 & & & & & ) & 18 & $\begin{array}{c}0 \\
0 \\
-1\end{array}$ \\
\hline \multirow{7}{*}{ 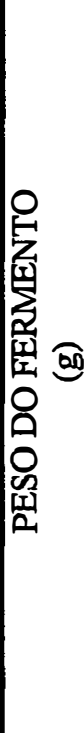 } & 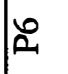 & $\begin{array}{l}\Delta \\
a \\
a\end{array}$ & 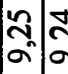 & 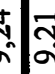 & $\begin{array}{l}\infty \\
\infty \\
\infty\end{array}$ & $\mid \begin{array}{l}\vec{\sigma}_{\infty} \\
\infty^{\prime}\end{array}$ & $\mid \begin{array}{c}\mathbb{N} \\
\mathbb{\infty}\end{array}$ & $\begin{array}{l}6 \\
\infty \\
\infty\end{array}$ & $\mid \begin{array}{c}\mathbb{N} \\
=\end{array}$ & $\begin{array}{c}\infty \\
\cdots \\
n^{\prime}\end{array} \mid$ & 它 & : & s. & nats & $\begin{array}{c}5 \\
\text { ș } \\
\end{array}$ \\
\hline & $\tilde{\alpha}$ & 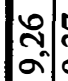 & \begin{tabular}{c|c}
$\tilde{m}$ & $\frac{m}{2}$ \\
$\sigma^{2}$ &
\end{tabular} & $\begin{array}{c}n \\
n\end{array}$ & $\hat{n}$ & $\mid \begin{array}{c}m \\
+\infty \\
\infty\end{array}$ & {$\left[\begin{array}{l}0 \\
n \\
\infty\end{array}\right.$} & $\begin{array}{l}m \\
\infty \\
\infty\end{array}$ & $\stackrel{a}{a}=$ & $=8$ & $=$ & & \begin{tabular}{c|c}
$n$ \\
2 \\
$n^{2}$ & 5 \\
\end{tabular} & $s$ & 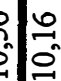 \\
\hline & 志 & $\left.\begin{array}{c}1 \\
\infty \\
\infty\end{array}\right]$ & 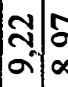 & $\begin{array}{c}0 \\
0 \\
0\end{array}$ & in & 6 & $\mid \begin{array}{l}0 \\
0\end{array}$ & 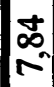 & $\mid$ & \begin{tabular}{l|r|r}
8 \\
$\infty$
\end{tabular} & & & $\begin{array}{lll}5 \\
n^{2}\end{array}$ & $=$ &  \\
\hline & $\tilde{n}$ & స్র & \begin{tabular}{|c|c|}
$\dot{m}^{2}$ & $\mathrm{n}$ \\
$\sigma^{2}$
\end{tabular} & $=\frac{1}{2}$ & $\underbrace{\mid}_{\infty}$ & $\mid \begin{array}{l}0 \\
\infty\end{array}$ & $\mid \begin{array}{l}0 \\
+ \\
\infty\end{array}$ & $\mid \begin{array}{c}m \\
m \\
\infty\end{array}$ & {$\left[\begin{array}{l}n \\
n \\
0\end{array}\right]$} & 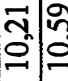 & : & & 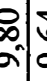 & \pm & $\frac{n}{a}$ \\
\hline & $\mathbb{\Sigma}$ & 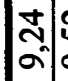 & 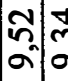 & $n_{0}^{\infty}$ & 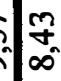 & $\mid \begin{array}{c}m \\
-\infty\end{array}$ & $\mid \begin{array}{l}n \\
0 \\
\infty\end{array}$ & $\begin{array}{c}\stackrel{8}{+} \\
\infty\end{array}$ & & \begin{tabular}{l|l}
$n$ \\
$\vdots$ \\
0 \\
0
\end{tabular} \mid & స్. & & 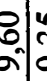 & & $\hat{n}^{2}$ \\
\hline & $\vec{a}$ & $\begin{array}{c}0 \\
\cdots \\
\sigma^{\prime}\end{array}$ & $\begin{array}{c}f \\
\sigma^{\prime} \\
0\end{array}$ & : & $\hat{s}$ & $\mid \begin{array}{c}m \\
\vdots \\
a\end{array}$ & $\mid \begin{array}{l}\infty \\
n \\
\alpha\end{array}$ & $\left|\begin{array}{l}\infty \\
\dot{+} \\
\sigma\end{array}\right|$ & & & & & 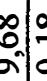 & & $\overbrace{n}^{\circ}$ \\
\hline & $\tilde{a}$ & $\begin{array}{c}8 \\
\infty \\
\infty\end{array}$ & \begin{tabular}{c|c}
8 & \\
$\infty$ & \\
$\infty$ &
\end{tabular} & \begin{tabular}{l|l}
$S_{0}$ & $\varepsilon$ \\
0
\end{tabular} & $\left\{\begin{array}{l}8 \\
0\end{array}\right.$ & $\mid \begin{array}{l}8 \\
\infty\end{array}$ & $\mid \begin{array}{l}0 \\
0 \\
\infty\end{array}$ & $\begin{array}{l}8 \\
\infty\end{array}$ & & $\underset{\infty}{8} \mid$ & 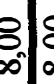 & & క్రి: & క్l|l & \begin{tabular}{l|l}
$\underbrace{}_{0}$ & 8 \\
\end{tabular} \\
\hline \multirow{6}{*}{ 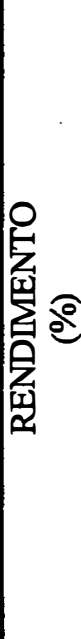 } & $\not 2$ & $\mid$\begin{tabular}{l}
0 \\
\hdashline-2 \\
\hdashline-2
\end{tabular} & $\begin{array}{lll}\approx & 0 \\
\approx & \sigma\end{array}$ & $\frac{n}{2}$ & $\mid \begin{array}{l}\infty \\
\infty \\
\infty\end{array}$ & $\mid$\begin{tabular}{c}
$\infty$ \\
\multirow{N}{*}{} \\
\hdashline
\end{tabular} & $\begin{array}{l}\mathbf{D} \\
\infty \\
\Omega^{\prime}\end{array}$ & $\mid \begin{array}{l}\infty \\
\infty \\
8\end{array}$ & $\left|\begin{array}{l}8 \\
8 \\
8\end{array}\right|$ & \begin{tabular}{l|l}
8 & \multirow{2}{*}{} \\
$\bar{\sigma}$ & $\overline{2}$
\end{tabular} & \begin{tabular}{l|l}
$n$ \\
5 \\
5
\end{tabular} & & $\approx$ & s. & 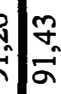 \\
\hline & 2 & $\begin{array}{l}\bar{\sigma} \\
\bar{a}\end{array}$ & $\begin{array}{l}\sigma_{2} \\
\bar{\sigma}\end{array} \mid$ & $\hat{\sigma}$ & $\left\{\begin{array}{l}\frac{m}{\sigma} \\
\sigma\end{array}\right.$ & $\mid \begin{array}{c}\infty \\
\infty \\
\tilde{a}\end{array}$ & م̊ & $\frac{q_{n}}{a}$ & $\left|\begin{array}{c}z_{n} \\
\delta\end{array}\right|$ & $\begin{array}{l}\sigma \\
\delta \\
\delta\end{array}$ & $\overline{0}$ & $=$ & 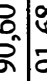 & & $\hat{n}$ \\
\hline & 声 & $\begin{array}{l}\hat{n} \\
\hat{\Omega} \\
\delta\end{array}$ & 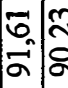 & 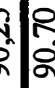 & $\left\{\begin{array}{l}\infty \\
- \\
-\end{array}\right.$ & $\mid \begin{array}{l}\infty \\
0 \\
0 \\
8\end{array}$ & $\mid \begin{array}{l}\infty \\
\infty \\
8\end{array}$ & $\stackrel{\circ}{a}$ & $\left.\mid \begin{array}{l}n \\
\cdots \\
\kappa\end{array}\right)$ & $\begin{array}{l}2 \\
\tilde{m}^{2} \\
\delta^{\prime}\end{array}$ & 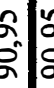 & & స్ & $\hat{n}$ & $\begin{array}{l}0 \\
\end{array}$ \\
\hline & $\mathscr{\not}$ & $\mid \begin{array}{l}\hat{\alpha} \\
\hat{\delta}\end{array}$ & 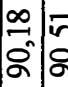 & in & {$\left[\begin{array}{l}m \\
\Omega_{n}\end{array}\right.$} & $\begin{array}{l}\Delta \\
\Omega^{\prime} \\
\Omega\end{array}$ & $\begin{array}{l}\hat{n} \\
\Omega^{2}\end{array}$ & $\begin{array}{l}0 \\
8 \\
8\end{array}$ & $\mid$ & \begin{tabular}{l|l}
$\tilde{m}$ & 8 \\
$\sigma^{2}$ & 8
\end{tabular} & 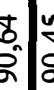 & c. & Ş & 8 & 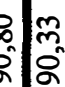 \\
\hline & $\approx 2$ & $\begin{array}{l}\tilde{\delta} \\
\delta \\
\delta \\
\delta\end{array}$ & 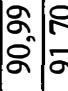 & 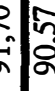 & $\left\{\begin{array}{l}2 \\
2_{2}\end{array}\right.$ & $\begin{array}{l}8 \\
8 \\
8 \\
8\end{array}$ & $\begin{array}{l}\infty \\
m \\
\infty \\
\infty\end{array}$ & $\begin{array}{l}\widehat{\sigma} \\
\infty \\
\infty\end{array}$ & $\left|\begin{array}{c}\infty \\
\infty \\
\infty\end{array}\right|$ & $\left|\begin{array}{l}7 \\
\vdots \\
\infty\end{array}\right| \infty$ & \begin{tabular}{l|l}
$\infty$ & 0 \\
$\infty$ & 0 \\
$\infty$ & 0
\end{tabular} & 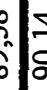 & \begin{tabular}{l|l} 
\pm \\
3 \\
3
\end{tabular} & $\begin{array}{c}c \\
\hat{0} \\
\hat{n}\end{array}$ & $\begin{array}{lll}0 \\
0 \\
0 \\
0\end{array}$ \\
\hline & $\widetilde{x}$ & $\left.\mid \begin{array}{c}m \\
\infty \\
\tilde{\infty} \\
\infty\end{array}\right]$ & \begin{tabular}{|l|l|} 
& $\tilde{D}$ \\
$\infty$ & $\infty$ \\
$\infty$ & $\infty$
\end{tabular} & 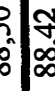 & $\mid \begin{array}{l}0 \\
-\infty\end{array}$ & $\begin{array}{c}\text { స్} \\
\infty \\
\infty\end{array}$ & $\begin{array}{l}\sqrt[n]{n} \\
\infty \\
\infty\end{array}$ & $\begin{array}{l}\infty \\
\infty \\
\infty \\
\infty\end{array}$ & $\left.\mid \begin{array}{l}8 \\
\infty \\
\infty \\
\infty\end{array}\right]$ & \begin{tabular}{|l|l}
$\frac{m}{2}$ & \multirow{\infty}{\infty}{} \\
$\infty$
\end{tabular} & 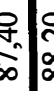 & \begin{tabular}{c|c}
0 \\
$\vdots$ \\
0
\end{tabular} & $\begin{array}{c}n \\
\infty \\
\infty\end{array} \mid$ & & 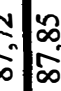 \\
\hline & $\frac{1}{2}$ & & 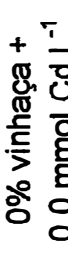 & 崖 & & 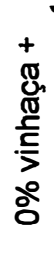 & 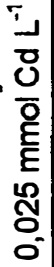 & 這 & & 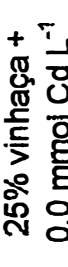 & 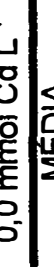 & & & 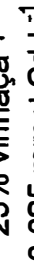 & \begin{tabular}{|l|l} 
\\
0 \\
0
\end{tabular} \\
\hline
\end{tabular}




\section{ANEXO 17}

\begin{tabular}{|c|c|c|c|c|c|c|c|c|c|c|c|c|c|c|c|c|c|}
\hline$\pi$ & & 占 & & \begin{tabular}{l|l} 
\\
\\
\end{tabular} & 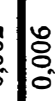 & 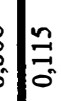 & 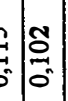 & $\begin{array}{l}\Xi \\
\\
0^{\circ}\end{array}$ & $\frac{0}{0}$ & 这 & $\mid$ & 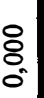 & $\begin{array}{l}8 \\
8 \\
0 \\
0\end{array}$ & $\mid \begin{array}{l}8 \\
0 \\
0\end{array}$ & & 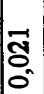 & s. \\
\hline & & 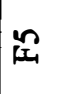 & $\left|\begin{array}{l}m \\
\delta_{0} \\
0\end{array}\right|$ & ఫి|రి & ô & $\int_{0}^{\circ}$ & $\begin{array}{l}8 \\
\vdots \\
\vdots\end{array}$ & {$\left[\begin{array}{l}\hat{2} \\
0 \\
0\end{array}\right.$} & F & $\left|\begin{array}{l}0 \\
0 \\
0\end{array}\right|$ & $\mid$ & 8. & ర్ & 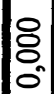 & & 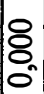 & 8. \\
\hline & कृ & 壱 & 8 & ৪్రి & ${ }_{0}^{\circ}$ & $\overbrace{0}$ & $\begin{array}{lll}D_{0} & 8 \\
\end{array}$ & 8 & $\begin{array}{l}8 \\
8 \\
0 \\
0\end{array}$ & ర్రి & ర్ & $\begin{array}{l}\tilde{c} \\
\bar{\delta} \\
\delta\end{array}$ & $\begin{array}{l}\text { ठ্ } \\
0 \\
0\end{array}$ & 8 & 要 & 要 & סे \\
\hline ( & 岱 & 玒 & $\mid \begin{array}{l}\nabla \\
0_{0} \\
0^{\prime}\end{array}$ & \begin{tabular}{l|l} 
\\
\end{tabular} & 8 & | & \begin{tabular}{l|l|l|}
5 \\
5
\end{tabular} & 8 & రి & - & $\mid$ & ర్. & $\begin{array}{l}8 \\
8 \\
0\end{array}$ & 8 & 8 & 8. & 8 \\
\hline 7 & & $\widetilde{I}$ & $\left|\begin{array}{l}8 \\
0 \\
0\end{array}\right|$ & ঠి|లి & $\int_{0}^{\circ}$ & $\int_{0}$ & $\begin{array}{l}5 \\
5 \\
5\end{array}$ & 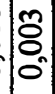 & 悹 & $\left|\begin{array}{l}\mid \\
0 \\
0 \\
0\end{array}\right|$ & $\mid \begin{array}{l}8 \\
0 \\
0\end{array}$ & ర్ & రิ & $\begin{array}{l}8 \\
8 \\
0 \\
0\end{array}$ & ర్ & 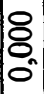 & סे \\
\hline & & $\bar{I}$ & $\mid \begin{array}{c}0 \\
\overline{0} \\
0\end{array}$ & 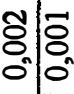 & $\delta_{0}$ & : & \begin{tabular}{l|l|l}
3 & 8 \\
0
\end{tabular} & ర్ & ర్. & $\left|\begin{array}{l}\tilde{\delta} \\
0 \\
0 \\
0\end{array}\right|$ & $\left|\begin{array}{l}\mid \\
0 \\
0 \\
0\end{array}\right|$ & $\begin{array}{l}8 \\
8 \\
0\end{array}$ & ర్ & 各 & 8 & 8 & $\begin{array}{l}8 \\
0 \\
0\end{array}$ \\
\hline & & క & $\begin{array}{l}0 \\
0 \\
0\end{array}$ & $\overbrace{0}^{0}$ & 8 & & $\begin{array}{lll}0 & 0 \\
0 & 0 \\
0\end{array}$ & 各 & $\begin{array}{l} \\
\\
0 \\
0\end{array}$ & $\mid \begin{array}{c}m \\
0 \\
0 \\
0\end{array}$ & $\mid$\begin{tabular}{c|}
$\mathbf{a}$ \\
0 \\
0 \\
0
\end{tabular} & $\begin{array}{l}= \\
0 \\
0 \\
0\end{array}$ & 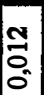 & $\mid \begin{array}{l}\Delta \\
0 \\
0 \\
0\end{array}$ & $\mid \begin{array}{l}\mathbf{z} \\
\dot{8} \\
0\end{array}$ & $\begin{array}{l}= \\
\overline{0} \\
0 \\
0\end{array}$ & $\begin{array}{l}0 \\
0 \\
0 \\
0\end{array}$ \\
\hline$\overline{b 0}$ & & 0 & ণ্ণ & \begin{tabular}{l|l} 
\\
\end{tabular} & $\delta_{0}$ & (5) & S. & 每 & s. & $\begin{array}{l}\mid \\
0 \\
0 \\
0\end{array}$ & $\mid \begin{array}{c}\cong \\
0 \\
0 \\
0\end{array}$ & $\begin{array}{l}\overline{0} \\
0 \\
0\end{array}$ & $\begin{array}{l}\bar{F} \\
\overline{0} \\
0 \\
0\end{array}$ & 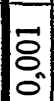 & $\mid \begin{array}{l}m \\
0 \\
0 \\
0\end{array}$ & $\mid \begin{array}{c}\tilde{y} \\
0 \\
0 \\
0\end{array}$ & ठे. \\
\hline & 볼 & 芯 & ৪্. & \begin{tabular}{l|l}
$\delta_{0}$ & 8 \\
\end{tabular} & 8 & م) & : & 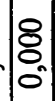 & $\overrightarrow{\delta_{0}}$ & ర్ & $\left|\begin{array}{c}0 \\
0 \\
0\end{array}\right|$ & ठृ & 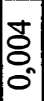 & 客 & 要 & 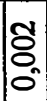 & $\begin{array}{l} \\
\\
\end{array}$ \\
\hline 串 芯 & 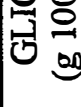 & 0 & ò & 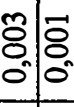 & 8 & $\mid \begin{array}{c}0 \\
0\end{array}$ & \begin{tabular}{l|l}
0 \\
$s_{0}^{2}$ & 0 \\
0
\end{tabular} & $\bar{\delta}$ & $\begin{array}{l}\infty \\
0 \\
0 \\
0\end{array}$ & 足 & $\left|\begin{array}{c}m \\
0 \\
0\end{array}\right|$ & 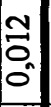 & $\bar{\sigma}^{-}$ & $\begin{array}{l}\tilde{O} \\
\tilde{O} \\
0 \\
0\end{array}$ & 吾 & 是 & $\begin{array}{l}\sigma \\
\vdots \\
0 \\
0\end{array}$ \\
\hline ப & & $\mathcal{O}$ & $\mid \begin{array}{l}0 \\
0 \\
0 \\
0\end{array}$ & : & م. & : & 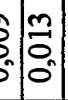 & oి & 응 & $\left|\begin{array}{l}m \\
0 \\
0 \\
0\end{array}\right|$ & $\left|\begin{array}{l}\mid \\
0 \\
0 \\
0\end{array}\right|$ & 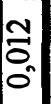 & \begin{tabular}{l} 
Na \\
\hdashline \\
0 \\
0
\end{tabular} & $\begin{array}{l}\sigma \\
0 \\
0 \\
0\end{array}$ & $\begin{array}{l}\mathcal{O} \\
0 \\
0 \\
0\end{array}$ & 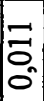 & $\begin{array}{l}0 \\
\stackrel{0}{0} \\
0 \\
0\end{array}$ \\
\hline 0 & & ত & : & हे| & $\int_{0}^{\circ}$ & : & $\mid \begin{array}{l}0 \\
0 \\
0\end{array}$ & 客. & s. & $\left|\begin{array}{l}0 \\
0 \\
0\end{array}\right|$ & $\left|\begin{array}{c}n \\
0 \\
0 \\
0\end{array}\right|$ & $\mid \begin{array}{l}T \\
0 \\
0\end{array}$ & $\begin{array}{l}\Delta \\
0 \\
0 \\
0\end{array}$ & $\left|\begin{array}{c}m \\
0 \\
0 \\
0\end{array}\right|$ & $\mid \begin{array}{l}m \\
0 \\
0 \\
0\end{array}$ & $\mid \begin{array}{l}m \\
0 \\
0 \\
0\end{array}$ & ma \\
\hline ప & & రి & $\begin{array}{c}0 \\
\hat{\sim} \\
\hat{\sim}\end{array} \mid$ & ন & $\stackrel{\infty}{\infty}$ & $\hat{n}$ & 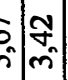 & $\mid \begin{array}{l}0 \\
m \\
m\end{array}$ & 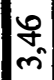 & $\left|\begin{array}{c}m \\
m \\
m\end{array}\right|$ & $\left|\begin{array}{l} \\
m\end{array}\right|$ & $\mid$ & $\begin{array}{l}\infty \\
m \\
m\end{array}$ & m & 文 & 点 & in \\
\hline$\underset{\mathbb{\Phi}}{\tilde{\Phi}}$ & & in & N. & $\begin{array}{c}m \\
m \\
m\end{array} \mid \begin{array}{l}\infty \\
\sim\end{array}$ & in & fio & 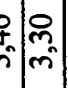 & N & 志 & $\frac{a}{m}$ & $\mid \begin{array}{c}0 \\
m^{n}\end{array}$ & $\begin{array}{c}\hat{N} \\
\mathrm{~m}\end{array}$ & $\frac{0}{m}$ & $\begin{array}{l}8 \\
n^{2} \\
m\end{array}$ & 吕 & $\begin{array}{l}m \\
m \\
m\end{array}$ & $\stackrel{m}{m}$ \\
\hline & & 芯 & 守 &  & m & in & $\begin{array}{c}n \\
n \\
n \\
m \\
m\end{array}$ & $\begin{array}{l}Z_{n} \\
m\end{array}$ & m & $\left|\begin{array}{l}R \\
m \\
m\end{array}\right|$ & $\left(\begin{array}{c}\infty \\
m \\
m\end{array}\right.$ & $\vec{b}$ & $F_{m}$ & $\stackrel{n}{m}$ & $\underset{\forall}{\approx}$ & $\mid \begin{array}{l}m \\
= \\
\sigma\end{array}$ & S̊ \\
\hline 0 & 00 & 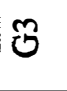 & 文 & $\begin{array}{c}m \\
m \\
m\end{array}$ & m & 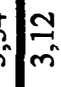 & $\begin{array}{ll}y & = \\
n & =\end{array}$ & $\begin{array}{l}8 \\
0 \\
m\end{array}$ & 음 & న్ & $\left|\begin{array}{c}n \\
m \\
m\end{array}\right|$ & m & m & $\begin{array}{l}\infty \\
m \\
m\end{array}$ & $\begin{array}{l}\infty \\
\infty \\
m \\
m\end{array}$ & $\begin{array}{c}\infty \\
m \\
m\end{array}$ & $\begin{array}{l}\infty \\
\infty \\
m\end{array}$ \\
\hline$\stackrel{\mathbb{2}}{2}$ & & $\widetilde{\delta}$ & $\left|\begin{array}{l}\infty \\
m \\
m\end{array}\right|$ & \begin{tabular}{c|c}
$\hat{m}$ \\
$m$ \\
$m$ & $m$ \\
$m$
\end{tabular} & f & f & $\hat{f} \begin{array}{l}f \\
\infty \\
m \\
m\end{array} \mid$ & $\begin{array}{l}g \\
g_{n}\end{array}$ & : & $\mid$ & $\left|\begin{array}{c}\text { in } \\
m \\
m\end{array}\right|$ & స̂. & $\begin{array}{l}m \\
m \\
m\end{array}$ & & F & $\mid \begin{array}{c}n \\
\infty \\
m \\
m\end{array}$ & 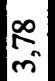 \\
\hline 0 & & & - & 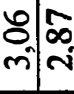 & : & î & 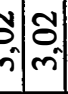 & : & o & $\left|\begin{array}{l}m \\
m \\
m\end{array}\right|$ & $\left|\begin{array}{c}m \\
m \\
m\end{array}\right|$ & స̃ & $\begin{array}{l}0 \\
m \\
m\end{array}$ & 孞 & & $\stackrel{m}{q}$ & $\begin{array}{l}\infty \\
\dot{c} \\
\dot{m}\end{array}$ \\
\hline 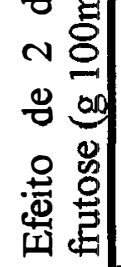 & & 点 & & 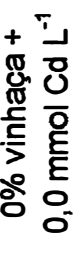 & $\frac{\Delta}{2}$ & & 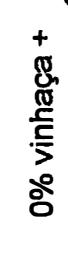 & 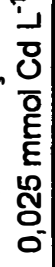 & $\frac{\Sigma}{\bar{i}}$ & & 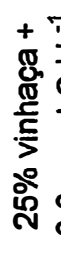 & $\begin{array}{l}\frac{0}{0} \\
\frac{0}{\varepsilon}\end{array}$ & $\frac{\varsigma}{5}$ & & & $\begin{array}{l}\mathcal{U} \\
\bar{O} \\
E \\
E \\
\stackrel{0}{0} \\
0 \\
0\end{array}$ & $\frac{5}{5}$ \\
\hline
\end{tabular}




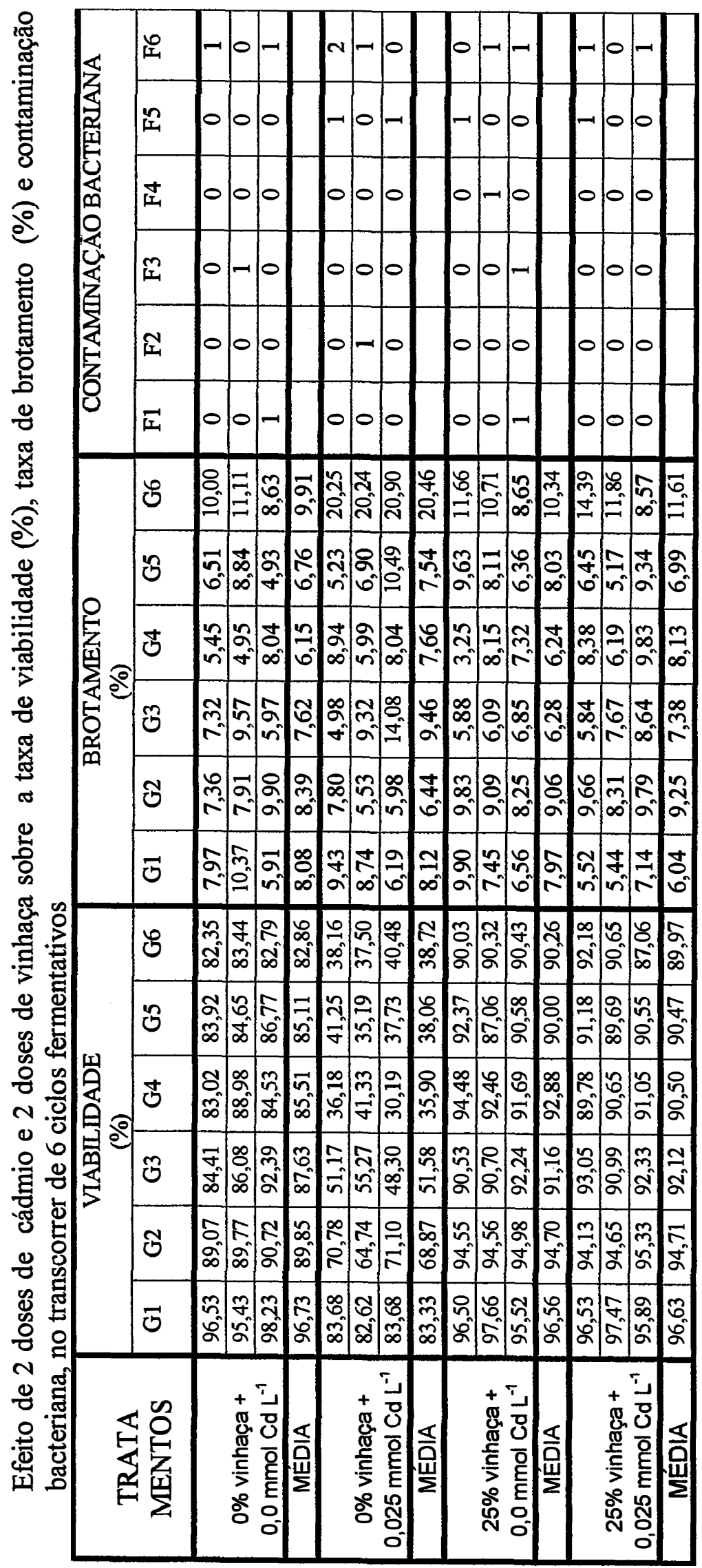


ANEXO 19






\section{ANEXO 20}

Efeito de 2 doses de cádmio e 2 doses de vinhaça sobre os teores de trealose (\% MS), glicogênio (\% MS) e nitrogênio (\% MS) iniciais e finais

\begin{tabular}{|c|c|c|c|c|c|c|}
\hline \multirow{2}{*}{$\begin{array}{c}\text { TRATA } \\
\text { MENTOS }\end{array}$} & \multicolumn{2}{|c|}{$\begin{array}{l}\text { TREALOSE } \\
(\% \mathrm{MS}) \\
\end{array}$} & \multicolumn{2}{|c|}{$\begin{array}{c}\text { GLICOGÊNIO } \\
(\% \mathrm{MS})\end{array}$} & \multicolumn{2}{|c|}{$\begin{array}{c}\text { NITROGENIO } \\
\text { (\% MS) }\end{array}$} \\
\hline & INICIAL & FINAL & INICIAL & FINAL & INICIAL & FINAL \\
\hline \multirow{3}{*}{$\begin{array}{c}0 \% \text { vinhaça }+ \\
0,0 \text { mmol } \mathrm{Cd} \mathrm{L}^{-1}\end{array}$} & 1,94 & 8,63 & 5,64 & 18,98 & 5,35 & 6,13 \\
\hline & 1,77 & 8,65 & 5,79 & 16,67 & 5,42 & 4,57 \\
\hline & 2,00 & 8,33 & 5,64 & 18,06 & 5,56 & 6,06 \\
\hline MÉDIA & 1,90 & 8,54 & 5,69 & 17,90 & 5,47 & 5,59 \\
\hline \multirow{3}{*}{$\begin{array}{c}0 \% \text { vinhaça }+ \\
0,025 \mathrm{mmol} \mathrm{Cd} \mathrm{L}^{-1}\end{array}$} & 1,94 & 6,48 & 5,64 & 24,11 & 5,35 & 6,28 \\
\hline & 1,77 & 4,74 & 5,79 & 21,59 & 5,42 & 6,28 \\
\hline & 2,00 & 5,93 & 5,64 & 20,38 & 5,56 & 5,48 \\
\hline MÉDIA & 1,90 & 5,71 & 5,69 & 22,03 & 5,47 & 6,01 \\
\hline \multirow{3}{*}{$\begin{array}{l}25 \% \text { vinhaça }+ \\
0,0 \mathrm{mmol} \mathrm{Cd} \mathrm{L}^{-1}\end{array}$} & 1,94 & 9,85 & 5,64 & 23,19 & 5,35 & 4,90 \\
\hline & 1,77 & 6,16 & 5,79 & 22,64 & 5,42 & 5,51 \\
\hline & 2,00 & 8,80 & 5,64 & 20,94 & 5,56 & 5,23 \\
\hline MEDIA & 1,90 & 8,27 & 5,69 & 22,26 & 5,47 & 5,21 \\
\hline \multirow{3}{*}{ 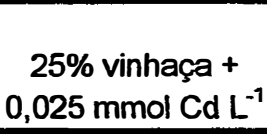 } & 1,94 & 8,31 & 5,64 & 19,49 & 5,35 & 5,48 \\
\hline & 1,77 & 9,00 & 5,79 & 19,76 & 5,42 & 5,44 \\
\hline & 2,00 & 8,78 & 5,64 & 22,33 & 5,56 & 5,56 \\
\hline MÉDIA & 1,90 & 8,70 & 5,69 & 20,53 & 5,47 & 5,49 \\
\hline
\end{tabular}




\section{ANEXO 21}

Efeito de 2 doses de cádmio e 2 doses de vinhaça sobre a velocidade da fermentação, estimada em produção de $\mathrm{CO}_{2}$ (em g) a cada hora, no transcorrer de 6 ciclos fermentativos.

\begin{tabular}{|c|c|c|c|c|c|c|c|c|c|}
\hline \multirow[b]{2}{*}{ TRATAMENTOS } & \multirow[b]{2}{*}{ CICLO } & \multicolumn{8}{|c|}{ PERDA DE PESO (g) } \\
\hline & & $1 \mathrm{~h}$ & $2 h$ & $3 \mathrm{~h}$ & $4 h$ & $5 \mathrm{~h}$ & $6 \mathrm{~h}$ & $7 \mathrm{~h}$ & $20 \mathrm{~h}$ \\
\hline \multirow{4}{*}{$\begin{array}{l}0,0 \mathrm{mmol} \mathrm{Cd} \mathrm{L}^{-1} \\
+0 \% \text { vinhaça }\end{array}$} & $\begin{array}{l}1 \\
2 \\
3\end{array}$ & $\begin{array}{l}0,617 \\
0,613 \\
0,380\end{array}$ & $\begin{array}{l}1,858 \\
1,825 \\
1,458\end{array}$ & $\begin{array}{l}2,922 \\
2,961 \\
2,657\end{array}$ & $\begin{array}{l}3,927 \\
3,841 \\
3,585\end{array}$ & $\begin{array}{l}4,828 \\
4,596 \\
4,461\end{array}$ & $\begin{array}{l}5,160 \\
5,092 \\
5,097\end{array}$ & $\begin{array}{l}5,276 \\
5,515 \\
5,898\end{array}$ & $\begin{array}{l}5,553 \\
5,920 \\
6,092\end{array}$ \\
\hline & 4 & 0,447 & 1,585 & 2,579 & 3,412 & 4,320 & 5,032 & 5,506 & 6,162 \\
\hline & 5 & 0,902 & 1,701 & 2,766 & 3,462 & 4,378 & 4,972 & 5,429 & 6,048 \\
\hline & 6 & 0,378 & 1,736 & 2,772 & 3,773 & 4,576 & 5,194 & 5,691 & 6,374 \\
\hline Média & & 0,556 & 1,694 & 2,776 & 3,667 & 4,527 & 5,091 & 5,553 & 6,025 \\
\hline \multirow{6}{*}{$\begin{array}{l}0,025 \mathrm{mmol} \mathrm{Cd} \mathrm{L}^{-1} \\
+0 \% \text { vinhaça }\end{array}$} & 1 & 0,154 & 1,430 & 2,599 & 3,678 & 4,650 & 5,192 & 5,360 & 5,990 \\
\hline & 2 & 0,532 & 1,438 & 3,072 & 3,970 & 4,786 & 5,309 & 5,868 & 6,547 \\
\hline & 3 & 0,147 & 0,991 & 1,949 & 2,791 & 3,593 & 4,468 & 5,008 & 5,606 \\
\hline & 4 & 0,246 & 1,200 & 2,076 & 2,744 & 3,527 & 4,126 & 4,592 & 6,146 \\
\hline & 5 & 0,475 & 0,893 & 1,981 & 2,556 & 3,352 & 3,878 & 4,427 & 5,936 \\
\hline & 6 & 0,212 & 1,343 & 2,155 & 3,049 & 3,731 & 4,279 & 4,826 & 6,277 \\
\hline Média & & 0,295 & 1,216 & 2,305 & 3,131 & 3,940 & 4,542 & 5,014 & 6,084 \\
\hline \multirow{6}{*}{ 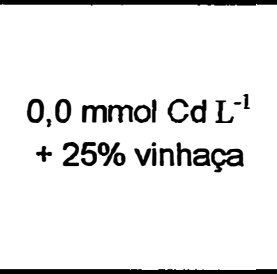 } & 1 & 0,041 & 1,387 & 2,709 & 4,025 & 4,870 & 5,017 & 5,099 & 5,336 \\
\hline & 2 & 0,530 & 1,901 & 3,185 & 4,131 & 4,944 & 5,261 & 5,443 & 5,747 \\
\hline & 3 & 0,306 & 1,558 & 2,892 & 4,001 & 4,890 & 5,355 & 5,517 & 5,865 \\
\hline & 4 & 0,481 & 1,890 & 3,089 & 4,050 & 4,976 & 5,529 & 5,778 & 6,280 \\
\hline & 5 & 0,586 & 1,458 & 2,513 & 3,260 & 4,055 & 4,546 & 4,829 & 5,799 \\
\hline & 6 & 0,262 & 1,612 & 2,605 & 3,660 & 4,435 & 4,962 & 5,396 & 6,240 \\
\hline Média & & 0,368 & 1,634 & 2,832 & 3,854 & 4,695 & 5,112 & 5,344 & 5,878 \\
\hline \multirow{6}{*}{$\begin{array}{l}0,025 \mathrm{mmol} \mathrm{Cd} \mathrm{L}^{-1} \\
+25 \% \text { vinhaça }\end{array}$} & 1 & 0,091 & 1,296 & 2,620 & 3,931 & 4,826 & 5,001 & 5,067 & 5,337 \\
\hline & 2 & 0,451 & 1,722 & 2,939 & 3,853 & 4,649 & 5,071 & 5,401 & 5,734 \\
\hline & 3 & 0,275 & 1,328 & 2,530 & 3,578 & 4,392 & 5,040 & 5,409 & 5,842 \\
\hline & 4 & 0,501 & 1,777 & 2,904 & 3,786 & 4,693 & 5,320 & 5,655 & 6,188 \\
\hline & 5 & 0,557 & 1,473 & 2,663 & 3,216 & 4,379 & 4,958 & 5,471 & 5,836 \\
\hline & 6 & 0,260 & 1,709 & 2,758 & 3,798 & 4,660 & 5,180 & 5,563 & 6,153 \\
\hline média & & 0,356 & 1,551 & 2,736 & 3,694 & 4,600 & 5,095 & 5,428 & 5,849 \\
\hline
\end{tabular}


Rendimento fermentativo (\%)

\begin{tabular}{|c|c|c|c|c|c|c|}
\hline \multirow{2}{*}{$\begin{array}{l}\text { Tratamentos } \\
\left(\mathrm{mmol} \mathrm{Cd} \mathrm{L}^{-1}\right)\end{array}$} & \multicolumn{6}{|c|}{ CICLOS FERMENTATIVOS } \\
\hline & $1^{\circ}$ & $2^{\circ}$ & $3^{\circ}$ & $4^{\circ}$ & $5^{\circ}$ & $6^{\circ}$ \\
\hline $\begin{array}{c}0,0 \text { cádmio } \\
0 \% \text { vinhaça }\end{array}$ & $88,42 \mathrm{Ba}$ & 90,57Aa & $90,55 \mathrm{Aa}$ & $90,70 \mathrm{Aa}$ & $91,63 \mathrm{Aa}$ & $91,15 \mathrm{Aa}$ \\
\hline $\begin{array}{c}0,025 \text { cádmio } \\
0 \% \text { vinhaça }\end{array}$ & $87,08 \mathrm{Ba}$ & $89,62 \mathrm{ABb}$ & $90,62 \mathrm{Aa}$ & $91,10 \mathrm{Aa}$ & $91,40 \mathrm{Aa}$ & 90,86Aa \\
\hline $\begin{array}{c}0,0 \text { cádmio } \\
25 \% \text { vinhaça }\end{array}$ & $88,20 \mathrm{Ba}$ & $89,38 \mathrm{Bb}$ & $90,45 \mathrm{Aa}$ & $90,95 \mathrm{Aa}$ & 91,10Aa & 90,59Aa \\
\hline $\begin{array}{l}0,025 \text { cádmio } \\
25 \% \text { vinhaça }\end{array}$ & $87,85 \mathrm{Ba}$ & $89,62 \mathrm{ABb}$ & $90,33 \mathrm{Aa}$ & $90,77 \mathrm{Aa}$ & 91,54Aa & $91,43 \mathrm{Aa}$ \\
\hline
\end{tabular}

COEFICIENTE DE VARIAÇÃ $\bar{A}=0,311 \quad \mathrm{~B}=0,762$

As médias seguidas pelas mesmas letras (maiúsculas ou minúsculas), não diferem entre sí dentro de uma mesma linha ou mesma coluna, de acordo com o teste de Tukey à $1 \%$ de significância.

Etanol (\% v/v)

\begin{tabular}{ccccccc}
\hline \hline $\begin{array}{c}\text { Tratamentos } \\
\left.(\mathrm{mmol} \mathrm{Cd} \mathrm{L})^{-1}\right)\end{array}$ & $1^{\circ}$ & $2^{\circ}$ & $3^{\circ}$ & $4^{\circ}$ & $5^{\circ}$ & $6^{\circ}$ \\
\hline $\begin{array}{c}0,0 \text { cádmio } \\
0 \% \text { vinhaça }\end{array}$ & $7,85 \mathrm{Ba}$ & $8,24 \mathrm{Aa}$ & $8,35 \mathrm{Aa}$ & $8,32 \mathrm{Aa}$ & $8,36 \mathrm{Aa}$ & $8,30 \mathrm{Aa}$ \\
$\begin{array}{c}0,025 \text { cádmio } \\
0 \% \text { vinhaça }\end{array}$ & $7,71 \mathrm{Ca}$ & $7,98 \mathrm{Bb}$ & $8,40 \mathrm{Aa}$ & $8,35 \mathrm{Aa}$ & $8,39 \mathrm{Aa}$ & $8,26 \mathrm{Aa}$ \\
$\begin{array}{c}0,0 \text { cádmio } \\
25 \% \text { vinhaça }\end{array}$ & $7,87 \mathrm{Ba}$ & $7,99 \mathrm{Bb}$ & $8,32 \mathrm{Aa}$ & $8,28 \mathrm{Aa}$ & $8,36 \mathrm{Aa}$ & $8,27 \mathrm{Aa}$ \\
0,025 cádmio & & & & & & \\
$25 \%$ vinhaça & $7,85 \mathrm{Ca}$ & $8,02 \mathrm{Bb}$ & $8,34 \mathrm{Aa}$ & $8,29 \mathrm{Aa}$ & $8,37 \mathrm{Aa}$ & $8,33 \mathrm{Aa}$ \\
\hline \hline
\end{tabular}

COEFICIENTE DE VARIAÇÃO: $\mathrm{A}=0,255 \mathrm{~B}=0,698$

As médias seguidas pelas mesmas letras (maísculas ou minúsculas), não diferem entre sí dentro de uma mesma linha ou mesma coluna, de acordo com o teste de Tukey à $1 \%$ de significância.

Peso do fermento (g)

\begin{tabular}{|c|c|c|c|c|c|c|c|}
\hline \multirow{2}{*}{$\begin{array}{l}\text { Tratamentos } \\
\left.(\mathrm{mmol} \mathrm{Cd} \mathrm{L})^{-1}\right)\end{array}$} & \multicolumn{7}{|c|}{ CICLOS FERMENTATIVOS } \\
\hline & Inicial & $1^{\circ}$ & $2^{\circ}$ & $3^{\circ}$ & $4^{\circ}$ & $5^{\circ}$ & $6^{\circ}$ \\
\hline $\begin{array}{l}0,0 \text { cádmio } \\
0 \% \text { vinhaça }\end{array}$ & $8,00 \mathrm{Ba}$ & $9,40 \mathrm{Ab}$ & 9,37Aa & $9,25 \mathrm{Ab}$ & $9,02 \mathrm{Aa}$ & $9,25 \mathrm{Aab}$ & 9,21Aab \\
\hline $\begin{array}{c}0,025 \text { cádmio } \\
0 \% \text { vinhaça }\end{array}$ & $8,00 \mathrm{Ba}$ & $9,48 \mathrm{Ab}$ & $8,40 \mathrm{Bb}$ & $8,33 \mathrm{Bc}$ & $8,44 \mathrm{Bb}$ & $8,53 \mathrm{Bb}$ & $8,67 \mathrm{Bb}$ \\
\hline $\begin{array}{c}0,0 \text { cádmio } \\
25 \% \text { vinhaça }\end{array}$ & $8,00 \mathrm{Ba}$ & $9,61 \mathrm{Ab}$ & $10,11 \mathrm{Aa}$ & $10,45 \mathrm{Aa}$ & $9,76 \mathrm{Aa}$ & $10,11 \mathrm{Aa}$ & $10,15 \mathrm{Aa}$ \\
\hline $\begin{array}{l}0,025 \text { cádmio } \\
25 \% \text { vinhaça }\end{array}$ & $8,00 \mathrm{Ba}$ & $9,41 \mathrm{Ab}$ & $9,54 \mathrm{Aa}$ & $9,75 \mathrm{Ab}$ & 9,71Aa & $10,16 \mathrm{Aa}$ & $10,37 \mathrm{Aa}$ \\
\hline
\end{tabular}

As médias seguidas pelas mesmas letras (maiúsculas ou minúsculas), não diferem entre sí dentro de uma mesma linha ou mesma coluna, de acordo com o teste de Tukey à $1 \%$ de significância. 
Taxa de Viabilidade (\%)

\begin{tabular}{|c|c|c|c|c|c|c|}
\hline \multirow{2}{*}{$\begin{array}{l}\text { Tratamentos } \\
\left.(\mathrm{mmol} \mathrm{Cd} \mathrm{L})^{-1}\right)\end{array}$} & \multicolumn{6}{|c|}{ CICLOS FERMENTATIVOS } \\
\hline & $1^{\circ}$ & $2^{\circ}$ & $3^{\circ}$ & $4^{\circ}$ & $5^{\circ}$ & $6^{\circ}$ \\
\hline $\begin{array}{c}0,0 \text { cádmio } \\
0 \% \text { vinhaça }\end{array}$ & $96,73 \mathrm{Aa}$ & $89,85 \mathrm{Ba}$ & $87,63 \mathrm{BCa}$ & $85,51 \mathrm{BCb}$ & $85,11 \mathrm{BCa}$ & $82,86 \mathrm{Cb}$ \\
\hline $\begin{array}{c}0,025 \text { cádmio } \\
0 \% \text { vinhaca }\end{array}$ & $83234 \mathrm{~h}$ & $6007 \mathrm{Dh}$ & 5 & 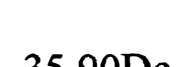 & $\mathrm{h}$ & 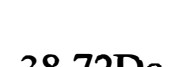 \\
\hline 0,0 cádmio & & $00,0 / D 0$ & J1,58CBO & $33,90 \mathrm{UDC}$ & 38,00100 & $38,7 \angle \mathrm{DC}$ \\
\hline $25 \%$ vinhaça & $96,56 \mathrm{Aa}$ & $94,70 \mathrm{Aa}$ & $91,16 \mathrm{Aa}$ & $92,88 \mathrm{Aa}$ & $90,00 \mathrm{Aa}$ & $90,26 \mathrm{Aa}$ \\
\hline $\begin{array}{l}0,025 \text { cádmio } \\
25 \% \text { vinhaça }\end{array}$ & $96,63 \mathrm{Aa}$ & $94,71 \mathrm{ABa}$ & $92,12 \mathrm{Aba}$ & $90,50 \mathrm{ABb}$ & $90,47 \mathrm{ABa}$ & $89,97 \mathrm{Ba}$ \\
\hline
\end{tabular}

COEFICIENTE DE VARIAÇÃO: $A=1,446 \quad B=2,731$

As médias seguidas pelas mesmas letras (maiúsculas ou minúsculas), não diferem entre sí dentro de uma mesma linha ou mesma coluna, de acordo com o teste de Tukey à $1 \%$ de significância.

Taxa de Brotamento (\%)

\begin{tabular}{ccccccc}
\hline \hline \multirow{2}{*}{$\begin{array}{c}\text { Tratamentos } \\
(\mathrm{mmol} \mathrm{Cd} \mathrm{L})\end{array}$} & $1^{\circ}$ & $2^{\circ}$ & $3^{\circ}$ & $4^{\circ}$ & $5^{\circ}$ & $6^{\circ}$ \\
\hline \hline $\begin{array}{c}0,0 \text { cádmio } \\
0 \% \text { vinhaça }\end{array}$ & $8,08 \mathrm{Aa}$ & $8,39 \mathrm{Aa}$ & $7,62 \mathrm{Aa}$ & $6,15 \mathrm{Aa}$ & $6,76 \mathrm{Aa}$ & $9,91 \mathrm{Ab}$ \\
0,025 cádmio & & & & & & \\
$\begin{array}{c}0 \% \text { vinhaça } \\
0,0 \text { cádmio }\end{array}$ & $8,12 \mathrm{Ba}$ & $6,44 \mathrm{Ba}$ & $9,46 \mathrm{Ba}$ & $7,66 \mathrm{Ba}$ & $7,54 \mathrm{Ba}$ & $20,46 \mathrm{Aa}$ \\
$\begin{array}{c}25 \% \text { vinhaça } \\
0,025 \text { cádmio }\end{array}$ & $7,97 \mathrm{Aa}$ & $9,06 \mathrm{Aa}$ & $6,28 \mathrm{Aa}$ & $6,24 \mathrm{Aa}$ & $8,03 \mathrm{Aa}$ & $10,34 \mathrm{Ab}$ \\
$25 \%$ vinhaça & $6,04 \mathrm{Ba}$ & $9,25 \mathrm{ABa}$ & $7,38 \mathrm{Aba}$ & $8,13 \mathrm{ABa}$ & $6,99 \mathrm{Aba}$ & $11,61 \mathrm{Ab}$ \\
\hline \hline
\end{tabular}

COEFICIENTE DE VARIAÇÃO: $\mathrm{A}=11,356 \quad \mathrm{~B}=20,761$

As médias seguidas pelas mesmas letras (maiúsculas ou minúculas), não diferem entre sí dentro de uma mesma linha ou mesma coluna, de acordo com o teste de Tukey à $1 \%$ de significância.

$\mathrm{pH}$ vinho

\begin{tabular}{|c|c|c|c|c|c|c|}
\hline \multirow{2}{*}{$\begin{array}{l}\text { Tratamentos } \\
\left(\mathrm{mmol} \mathrm{Cd} \mathrm{L}^{-1}\right)\end{array}$} & \multicolumn{6}{|c|}{ CICLOS FERMENTATIVOS } \\
\hline & $1^{\circ}$ & $2^{\circ}$ & $3^{\circ}$ & $4^{\circ}$ & $5^{\circ}$ & $6^{\circ}$ \\
\hline $\begin{array}{c}0,0 \text { cádmio } \\
0 \% \text { vinhaça }\end{array}$ & $3,40 \mathrm{Ab}$ & $3,40 \mathrm{Ac}$ & $3,13 \mathrm{Bb}$ & $3,19 \mathrm{Bb}$ & $3,08 \mathrm{Bb}$ & $3,08 \mathrm{Bb}$ \\
\hline $\begin{array}{c}0,025 \text { cádmio } \\
0 \% \text { vinhaça }\end{array}$ & $3,42 \mathrm{Ab}$ & $3,37 \mathrm{Ac}$ & $3,15 \mathrm{Bb}$ & $3,10 \mathrm{Bb}$ & $3,06 \mathrm{Bb}$ & $3,10 \mathrm{Bb}$ \\
\hline $\begin{array}{c}0,0 \text { cádmio } \\
25 \% \text { vinhaça }\end{array}$ & $4,03 \mathrm{Aa}$ & $4,06 \mathrm{Ab}$ & $4,11 \mathrm{Aa}$ & $4,23 \mathrm{Aa}$ & $4,09 \mathrm{Aa}$ & $4,09 \mathrm{Aa}$ \\
\hline $\begin{array}{l}0,025 \text { cádmio } \\
25 \% \text { vinhaça }\end{array}$ & $4,11 \mathrm{Aa}$ & 4,29Aba & $4,00 \mathrm{Ba}$ & $4,07 \mathrm{Ba}$ & $4,02 \mathrm{Ba}$ & $4,03 \mathrm{Ba}$ \\
\hline
\end{tabular}

COEFICIENTE DE VARIAÇÃO: $\mathrm{A}=0,925 \quad \mathrm{~B}=1,863$

As médias seguidas pelas mesmas letras (maiúsculas ou minúculas), não diferem entre sí dentro de uma mesma linha ou mesma coluna, de acordo com o teste de Tukey à $1 \%$ de significância. 
Glicerol (g/100 mg ART)

\begin{tabular}{|c|c|c|c|c|c|c|}
\hline \multirow{2}{*}{$\begin{array}{l}\text { Tratamentos } \\
\left(\mathrm{mmol} \mathrm{Cd} \mathrm{L}^{-1}\right)\end{array}$} & \multicolumn{6}{|c|}{ CICLOS FERMENTATIVOS } \\
\hline & $1^{\circ}$ & $2^{\circ}$ & $3^{\circ}$ & $4^{\circ}$ & $5^{\circ}$ & $6^{\circ}$ \\
\hline $\begin{array}{c}0,0 \text { cádmio } \\
0 \% \text { vinhaça }\end{array}$ & $3,00 \mathrm{Bc}$ & $3,47 \mathrm{Ac}$ & $3,34 \mathrm{Ab}$ & $3,03 \mathrm{Bd}$ & $3,05 \mathrm{Bb}$ & $2,98 \mathrm{Bb}$ \\
\hline $\begin{array}{l}0,025 \text { cádmio } \\
0 \% \text { vinhaça }\end{array}$ & $3,01 \mathrm{Cc}$ & $3,60 \mathrm{Ab}$ & $3,10 \mathrm{Cc}$ & $3,38 \mathrm{Bc}$ & $3,34 \mathrm{Ba}$ & $3,46 \mathrm{Da}$ \\
\hline $\begin{array}{c}0,0 \text { cádmio } \\
25 \% \text { vinhaça }\end{array}$ & $3,30 \mathrm{Bb}$ & $3,53 \mathrm{Bb}$ & $3,44 \mathrm{Bb}$ & $3,71 \mathrm{Ab}$ & $3,16 \mathrm{Cb}$ & $3,38 \mathrm{Bca}$ \\
\hline $\begin{array}{l}0,025 \text { cádmio } \\
25 \% \text { vinhaça }\end{array}$ & $3,48 \mathrm{Ca}$ & $3,78 \mathrm{Ba}$ & $3,86 \mathrm{Ba}$ & $4,07 \mathrm{Aa}$ & $3,43 \mathrm{Ca}$ & $3,57 \mathrm{Ca}$ \\
\hline
\end{tabular}

COEFICIENTE DE VARIAÇÃO: $\mathrm{A}=1,357 \quad \mathrm{~B}=3,827$

As médias seguidas pelas mesmas letras (maiúsculas ou minúculas), não diferem entre sí dentro de uma mesma linha ou mesma coluna, de acordo com o teste de Tukey à $1 \%$ de significância.

Glicose residual no vinho $\left(\mathrm{g} 100 \mathrm{~mL}^{-1}\right)$

\begin{tabular}{ccccccc}
\hline Tratamentos & \multicolumn{7}{c}{ CICLOS FERMENTATIVOS } \\
\cline { 2 - 7 }$\left(\mathrm{mmol} \mathrm{Cd} \mathrm{L^{-1 } )}\right.$ & $1^{\circ}$ & $2^{\circ}$ & $3^{\circ}$ & $4^{\circ}$ & $5^{\circ}$ & $6^{\circ}$ \\
\hline $\begin{array}{c}0,0 \text { cádmio } \\
0 \% \text { vinhaça }\end{array}$ & $0,006 \mathrm{Aa}$ & $0,011 \mathrm{Aa}$ & $0,004 \mathrm{Aa}$ & $0,000 \mathrm{Aa}$ & $0,003 \mathrm{Ab}$ & $0,007 \mathrm{Aa}$ \\
$\begin{array}{c}0,025 \text { cádmio } \\
0 \% \text { vinhaça }\end{array}$ & $0,007 \mathrm{ABCa}$ & $0,010 \mathrm{ABCa}$ & $0,018 \mathrm{Aba}$ & $0,001 \mathrm{Ca}$ & $0,021 \mathrm{Aa}$ & $0,004 \mathrm{Bca}$ \\
$\begin{array}{c}0,0 \text { cádmio } \\
25 \% \text { vinhaça }\end{array}$ & $0,014 \mathrm{Aa}$ & $0,012 \mathrm{Aa}$ & $0,011 \mathrm{Aa}$ & $0,004 \mathrm{Aa}$ & $0,011 \mathrm{Aab}$ & $0,012 \mathrm{Aa}$ \\
0,025 cádmio & & & & & & \\
$25 \%$ vinhaça & $0,013 \mathrm{Aa}$ & $0,012 \mathrm{Aa}$ & $0,011 \mathrm{Aa}$ & $0,004 \mathrm{Aa}$ & $0,009 \mathrm{Aab}$ & $0,010 \mathrm{Aa}$ \\
\hline
\end{tabular}

COEFICIENTE DE VARIAÇÃO: $\mathrm{A}=7,868 \quad \mathrm{~B}=9,179$

As médias seguidas pelas mesmas letras (maiúsculas ou minúculas), não diferem entre sí dentro de uma mesma linha ou mesma coluna, de acordo com o teste de Tukey à $1 \%$ de significância.

Frutose residual no vinho $\left(\mathrm{g} 100 \mathrm{~mL}^{-1}\right)$

\begin{tabular}{ccccccc}
\hline \hline Tratamentos & \multicolumn{7}{c}{ CICLOS FERENTATIVOS } \\
\cline { 3 - 7 }$\left(\mathrm{mmol} \mathrm{Cd} \mathrm{L^{-1 } )}\right.$ & $1^{\circ}$ & $2^{\circ}$ & $3^{\circ}$ & $4^{\circ}$ & $5^{\circ}$ & $6^{\circ}$ \\
\hline 0,0 cádmio & & & & & & \\
$0 \%$ vinhaça & $0,002 \mathrm{Aa}$ & $0,005 \mathrm{Aa}$ & $0,006 \mathrm{Aa}$ & $0,010 \mathrm{Aa}$ & $0,005 \mathrm{Ab}$ & $0,006 \mathrm{Ab}$ \\
$\begin{array}{c}0,025 \text { cádmio } \\
0 \% \text { vinhaça }\end{array}$ & $0,002 \mathrm{Ca}$ & $0,004 \mathrm{Ca}$ & $0,000 \mathrm{Ca}$ & $0,004 \mathrm{Ca}$ & $0,042 \mathrm{Ba}$ & $0,109 \mathrm{Aa}$ \\
$\begin{array}{c}0,0 \text { cádmio } \\
25 \% \text { vinhaça }\end{array}$ & $0,002 \mathrm{Aa}$ & $0,002 \mathrm{Aa}$ & $0,000 \mathrm{Aa}$ & $0,004 \mathrm{Aa}$ & $0,002 \mathrm{Ab}$ & $0,000 \mathrm{Ab}$ \\
0,025 cádmio & & & & & & \\
$25 \%$ vinhaça & $0,000 \mathrm{Aa}$ & $0,000 \mathrm{Aa}$ & $0,000 \mathrm{Aa}$ & $0,003 \mathrm{Aa}$ & $0,000 \mathrm{Ab}$ & $0,007 \mathrm{Ab}$ \\
\hline
\end{tabular}

COEFICIENTE DE VARIAÇÃO: $A=10,120 \quad B=14,239$

As médias seguidas pelas mesmas letras (maiúsculas ou minúculas), não diferem entre sí dentro de uma mesma linha ou mesma coluna, de acordo com o teste de Tukey à $1 \%$ de significância. 
Teor residual de sacarose no vinho $\left(\mathrm{g} 100 \mathrm{~mL}^{-1}\right)$

\begin{tabular}{ccccccc}
\hline Tratamentos & \multicolumn{7}{c}{ CICLOS FERMENTATIVOS } \\
\cline { 2 - 7 }$\left.(\mathrm{mmol} \mathrm{Cd} \mathrm{L})^{-1}\right)$ & $1^{\circ}$ & $2^{\circ}$ & $3^{\circ}$ & $4^{\circ}$ & $5^{\circ}$ & $6^{\circ}$ \\
\hline \hline $\begin{array}{c}0,0 \text { cádmio } \\
0 \% \text { vinhaça }\end{array}$ & $0,003 \mathrm{Aa}$ & $0,001 \mathrm{Aa}$ & $0,000 \mathrm{Aa}$ & $0,000 \mathrm{Ab}$ & $0,000 \mathrm{Aa}$ & $0,004 \mathrm{Aa}$ \\
$\begin{array}{c}0,025 \text { cádmio } \\
0 \% \text { vinhaça }\end{array}$ & $0,006 \mathrm{Aa}$ & $0,003 \mathrm{Aa}$ & $0,000 \mathrm{Aa}$ & $0,000 \mathrm{Ab}$ & $0,000 \mathrm{Aa}$ & $0,000 \mathrm{Aa}$ \\
$\begin{array}{c}0,0 \text { cádmio } \\
25 \% \text { vinhaça }\end{array}$ & $0,017 \mathrm{Aa}$ & $0,010 \mathrm{Aa}$ & $0,010 \mathrm{Aa}$ & $0,002 \mathrm{Ab}$ & $0,005 \mathrm{Aa}$ & $0,013 \mathrm{Aa}$ \\
0,025 cádmio & & & & & & \\
$25 \%$ vinhaça & $0,012 \mathrm{Ba}$ & $0,013 \mathrm{Ba}$ & $0,014 \mathrm{Ba}$ & $0,036 \mathrm{Aa}$ & $0,011 \mathrm{Ba}$ & $0,010 \mathrm{Ba}$ \\
\hline \hline
\end{tabular}

COEFICIENTE DE VARIAÇÃO: $\mathrm{A}=7,221 \quad \mathrm{~B}=12,644$

As médias seguidas pelas mesmas letras (maiúsculas ou minúculas), não diferem entre sí dentro de uma mesma linha ou mesma coluna, de acordo com o teste de Tukey à $1 \%$ de significância.

Teor inicial e final de glicogênio (\% MS), trealose (\% MS) e nitrogênio (\% MS)

\begin{tabular}{cccc}
\hline \hline $\begin{array}{c}\text { Tratamentos } \\
\text { mmol Cd L }\end{array}$ & $\begin{array}{c}\text { Glicogênio } \\
(\% \mathrm{MS})\end{array}$ & $\begin{array}{c}\text { Trealose } \\
(\% \mathrm{MS})\end{array}$ & $\begin{array}{c}\text { Nitrogênio } \\
(\% \mathrm{MS})\end{array}$ \\
\hline $\begin{array}{c}\text { Inicial } \\
0,0 \text { cádmio }\end{array}$ & $5,69 \mathrm{C}$ & $1,90 \mathrm{C}$ & $5,47 \mathrm{~A}$ \\
$0 \%$ vinhaça & $17,90 \mathrm{~B}$ & $8,54 \mathrm{~A}$ & $5,59 \mathrm{~A}$ \\
0,025 cádmio & & & \\
$0 \%$ vinhaça & $22,03 \mathrm{~A}$ & $5,71 \mathrm{~B}$ & $6,01 \mathrm{~A}$ \\
0,0 cádmio & & & \\
$\begin{array}{c}25 \% \text { vinhaça } \\
0,025 \text { cádmio }\end{array}$ & $22,26 \mathrm{~A}$ & $8,27 \mathrm{~A}$ & $5,21 \mathrm{~A}$ \\
$25 \%$ vinhaça & $20,53 \mathrm{~A}$ & $8,70 \mathrm{~A}$ & $5,49 \mathrm{~A}$ \\
\hline \hline
\end{tabular}

As médias seguidas pelas mesmas letras, não diferem entre sí dentro de uma mesma coluna, de acordo com o teste de Tukey à $1 \%$ de significância. 
ANEXO 23

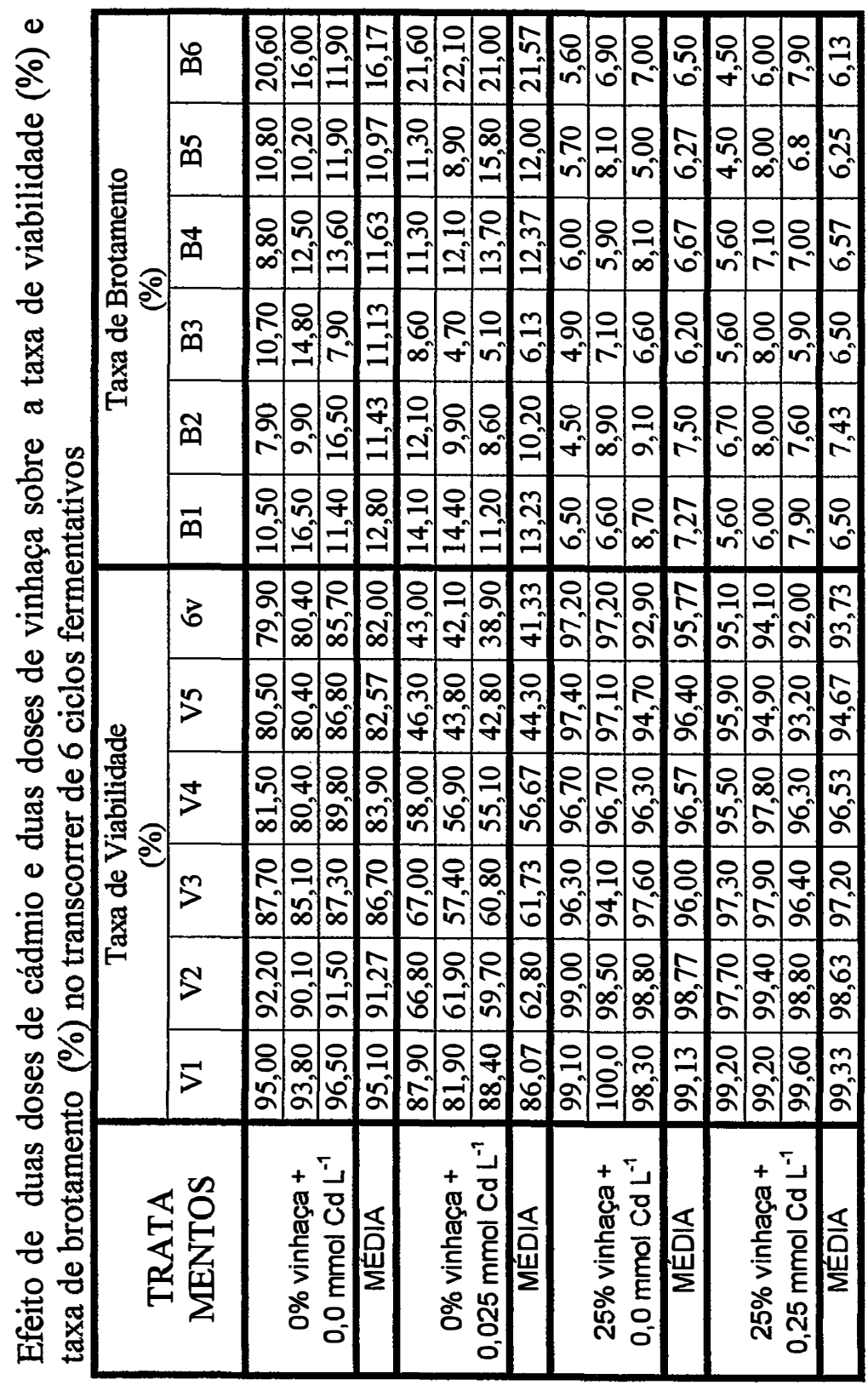


ANEXO 24

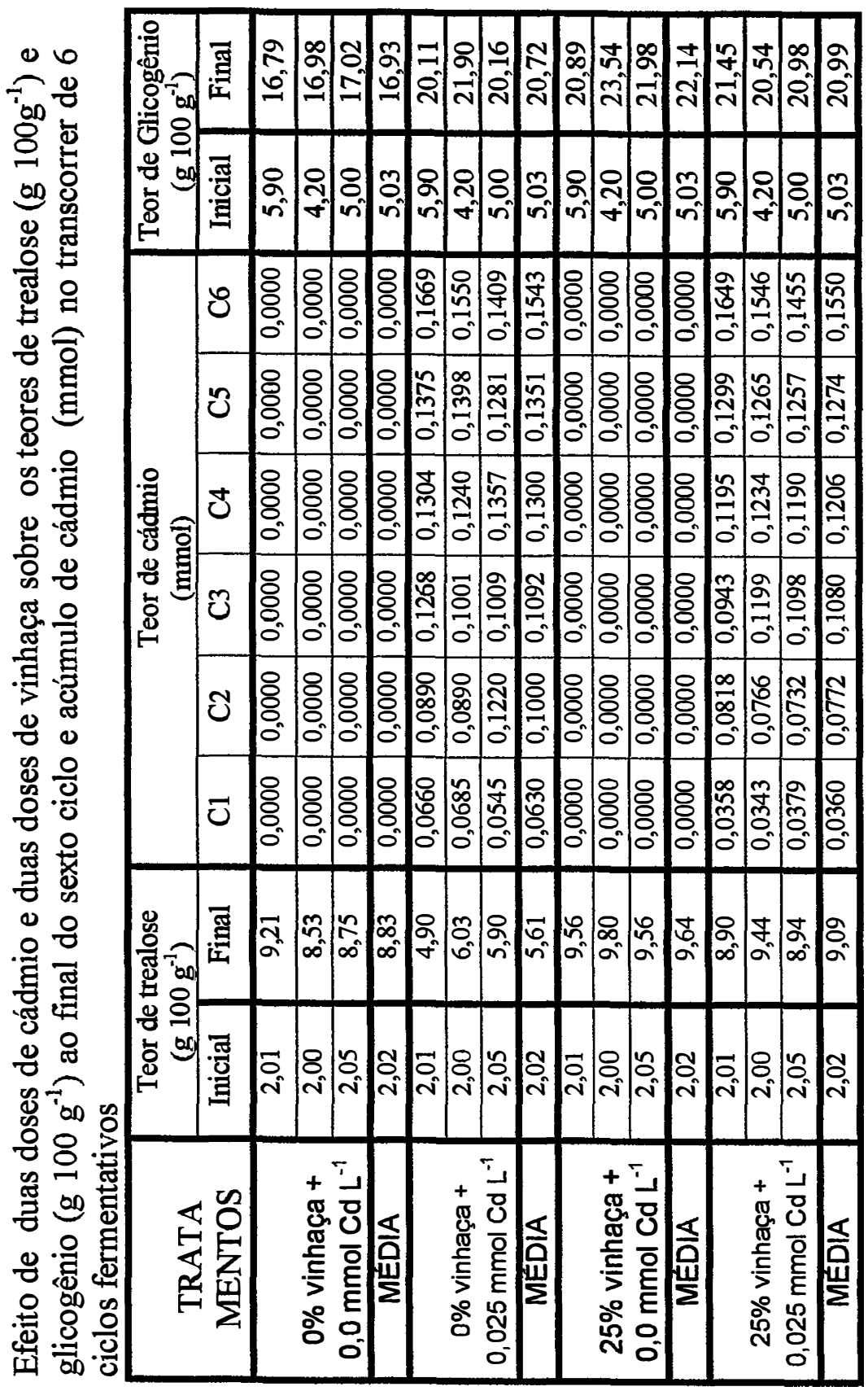




\section{ANEXO 25}

Taxa de viabilidade (\%)

\begin{tabular}{ccccccc}
\hline \hline \multirow{2}{*}{$\begin{array}{c}\text { Tratamentos } \\
\left(\text { mmol Cd L } \mathrm{L}^{-1}\right)\end{array}$} & $1^{\circ}$ & $2^{\circ}$ & \multicolumn{6}{c}{ CICLOS FERMENTATIVOS } & $3^{\circ}$ & $4^{\circ}$ & $5^{\circ}$ & $6^{\circ}$ \\
\hline \hline $\begin{array}{c}0,0 \text { cádmio } \\
0 \% \text { vinhaça }\end{array}$ & $95,10 \mathrm{Aa}$ & $91,27 \mathrm{Aa}$ & $86,70 \mathrm{ABb}$ & $83,90 \mathrm{Bb}$ & $82,57 \mathrm{Bb}$ & $82,00 \mathrm{Bb}$ \\
$\begin{array}{c}0,025 \text { cádmio } \\
0 \% \text { vinhaça }\end{array}$ & $86,07 \mathrm{Ab}$ & $62,80 \mathrm{Bb}$ & $61,73 \mathrm{Bc}$ & $56,67 \mathrm{Cc}$ & $44,30 \mathrm{Dc}$ & $41,33 \mathrm{Dc}$ \\
$\begin{array}{c}0,0 \text { cádmio } \\
25 \% \text { vinhaça }\end{array}$ & $99,13 \mathrm{Aa}$ & $98,77 \mathrm{Aa}$ & $96,00 \mathrm{Aa}$ & $96,57 \mathrm{Aa}$ & $96,40 \mathrm{Aa}$ & $95,77 \mathrm{Aa}$ \\
$\begin{array}{c}0,025 \text { cádmio } \\
25 \% \text { vinhaça }\end{array}$ & $99,33 \mathrm{Aa}$ & $98,63 \mathrm{Aa}$ & $97,20 \mathrm{Aa}$ & $96,53 \mathrm{ABa}$ & $94,67 \mathrm{Ba}$ & $93,73 \mathrm{Ba}$ \\
\hline
\end{tabular}

COEFICIENTE DE VARIAÇÃO: $\mathrm{A}=5,95 \mathrm{~B}=7,98$

As médias seguidas pelas mesmas letras (maiúsculas ou minúsculas), não diferem entre sí dentro de uma mesma linha ou mesma coluna, de acordo com o teste de Tukey à $1 \%$ de significância.

Taxa de Brotamento (\%)

\begin{tabular}{|c|c|c|c|c|c|c|}
\hline \multirow{2}{*}{$\begin{array}{l}\text { Tratamentos } \\
\left.(\mathrm{mmol} \mathrm{Cd} \mathrm{L})^{-1}\right)\end{array}$} & \multicolumn{6}{|c|}{ CICLOS FERMENTATIVOS } \\
\hline & $1^{\circ}$ & $2^{\circ}$ & $3^{\circ}$ & $4^{\circ}$ & $5^{\circ}$ & $6^{\circ}$ \\
\hline $\begin{array}{c}0,0 \text { cádmio } \\
0 \% \text { vinhaça }\end{array}$ & $12,80 \mathrm{Ba}$ & $11,43 \mathrm{Bb}$ & $11,13 \mathrm{Bb}$ & $11,63 \mathrm{Bb}$ & $10,97 \mathrm{Bb}$ & $16,17 \mathrm{Ab}$ \\
\hline $\begin{array}{c}0,025 \text { cádmio } \\
0 \% \text { vinhaça }\end{array}$ & $13,23 \mathrm{Ba}$ & $10,20 \mathrm{Bb}$ & $6,13 \mathrm{Cc}$ & $12,37 \mathrm{Bb}$ & $12,00 \mathrm{Bb}$ & $21,57 \mathrm{Aa}$ \\
\hline $\begin{array}{l}0,0 \text { cádmio } \\
25 \% \text { vinhaça }\end{array}$ & 7,27Ab & 7,50Ac & 6,20Ac & 6,67Ac & 6,27Ac & 6,50Ac \\
\hline $\begin{array}{l}0,025 \text { cádmio } \\
25 \% \text { vinhaça }\end{array}$ & $6,50 \mathrm{Ab}$ & 7,43Ac & 6,50Ac & $6,57 \mathrm{Ac}$ & $6,25 \mathrm{Ac}$ & $6,13 \mathrm{Ac}$ \\
\hline
\end{tabular}

COEFICIENTE DE VARIAÇÃO: $\mathrm{A}=4,351 \quad \mathrm{~B}=4,262$

As médias seguidas pelas mesmas letras (maiúsculas ou minúsculas), não diferem entre sí dentro de uma mesma linha ou mesma coluna, de acordo com o teste de Tukey à $1 \%$ de significância. 
Acúmulo de cádmio (\%)

\begin{tabular}{|c|c|c|c|c|c|c|}
\hline \multirow{2}{*}{$\begin{array}{l}\text { Tratamentos } \\
\left((\mathrm{mmol} \mathrm{Cd} \mathrm{L})^{-1}\right.\end{array}$} & \multicolumn{6}{|c|}{ CICLOS FERMENTATIVOS } \\
\hline & $1^{\circ}$ & $2^{\circ}$ & $3^{\circ}$ & $4^{\circ}$ & $5^{\circ}$ & $6^{\circ}$ \\
\hline $\begin{array}{c}0,0 \text { cádmio } \\
0 \% \text { vinhaça }\end{array}$ & $0,0000 \mathrm{Ab}$ & $0,0000 \mathrm{Ab}$ & $0,0000 \mathrm{Ac}$ & $0,0000 \mathrm{Ac}$ & $0,0000 \mathrm{Ac}$ & $0,0000 \mathrm{Ac}$ \\
\hline $\begin{array}{c}0,025 \text { cádmio } \\
0 \% \text { vinhaça }\end{array}$ & $0,0630 \mathrm{Db}$ & $0,1000 \mathrm{Cb}$ & $0,1092 \mathrm{Cb}$ & $0,1300 \mathrm{Bb}$ & $0,1351 \mathrm{Bb}$ & $0,1543 \mathrm{Ab}$ \\
\hline $\begin{array}{c}0,0 \text { cádmio } \\
25 \% \text { vinhaça }\end{array}$ & $0,0000 \mathrm{Ab}$ & $0,0000 \mathrm{Ab}$ & $0,0000 \mathrm{Ac}$ & $0,0000 \mathrm{Ac}$ & $0,0000 \mathrm{Ac}$ & $0,0000 \mathrm{Ac}$ \\
\hline $\begin{array}{l}0,025 \text { cádmio } \\
25 \% \text { vinhaça }\end{array}$ & $0,0360 \mathrm{Db}$ & $0,0772 \mathrm{Cb}$ & $0,1080 \mathrm{Bb}$ & $0,1206 \mathrm{Bb}$ & $0,1274 \mathrm{Bb}$ & $0,15500 \mathrm{Ab}$ \\
\hline
\end{tabular}

As médias seguidas pelas mesmas letras (maiúsculas ou minúsculas), não diferem entre sí dentro de uma mesma linha ou mesma coluna, de acordo com o teste de Tukey à $1 \%$ de significância

Teor inicial e final de glicogênio (\% MS) e trealose (\% MS)

\begin{tabular}{ccc}
\hline $\begin{array}{c}\text { Tratamentos } \\
(\text { mmol Cd L }\end{array}$ & $\begin{array}{c}\text { Glicogênio } \\
(\% \mathrm{MS})\end{array}$ & $\begin{array}{c}\text { Trealose } \\
(\% \mathrm{MS})\end{array}$ \\
\hline $\begin{array}{c}\text { Inicial } \\
0,0 \text { cádmio }\end{array}$ & $5,03 \mathrm{D}$ & $2,02 \mathrm{D}$ \\
$0 \%$ vinhaça & $16,93 \mathrm{C}$ & $8,83 \mathrm{~B}$ \\
0,025 cádmio & & $5,61 \mathrm{C}$ \\
$0 \%$ vinhaça & $20,72 \mathrm{~B}$ & $9,64 \mathrm{~A}$ \\
$\begin{array}{c}0,0 \text { cádmio } \\
25 \% \text { vinhaça }\end{array}$ & $22,14 \mathrm{~B}$ & $9,09 \mathrm{AB}$ \\
0,025 cádmio & $20,99 \mathrm{~B}$ & \\
$25 \%$ vinhaça & & \\
\hline
\end{tabular}

Coeficiente de variação

(\%) 6,276 5,435

As médias seguidas pelas mesmas letras, não diferem entre sí dentro de uma mesma coluna, de acordo com 0 teste de Tukey à $1 \%$ de significância. 


\section{REFERÊNCIAS BIBLIOGRÁFICAS}

ADRIANO, D. C. Cadmium. In: ADRIANO, C. C. Trace elements in the terrestrial environment. New York: Springer-Velang, 1986. cap.4, p.105-155.

ALBERTINI, S. Isotermas de adsorção de cádmio por Saccharomyces cerevisiae. Piracicaba, 1999. 54p. Dissertação (Mestrado) - Escola Superior de Agricultura "Luiz de Queiroz", Universidade de São Paulo.

ALLOWAY, B. I. The origins of heavy metals in soils. In: ALLOWAY, B. I. Heavy metals in soils. 2. ed. New York: John Wiley, 1995. cap.3, p.38-57.

AMORIM, H. V.; OLIVEIRA, A. J.; ZAGO, E. A.; BASSO, L. C.; GALLO, C. R. Processos de fermentação alcoólica: seu controle e monitoramento. Piracicaba: FERMENTEC, 1989. 145 p.

ARTEAGA, D. H. Dinâmica de cádmio, chumbo, cobre, níquel e zinco no sistema solo-planta. Viçosa, 1996. 90p. Dissertação (Mestrado) - Universidade Federal de Viçosa. 
ASSMAN, S.; SIGLER, K.; HÖFER, M. $\mathrm{Cd}^{+2}$-induced damage to yeast plasma membrane and its alleviation by $\mathrm{Zn}^{+2}$ : studies on Schizosaccharomyces pombe cells and reconstituted plasma membrane vesicles. Archives of Microbiology, v.165, n.4, p.279-284, 1996.

BABICH, H.; STOTZKY, G. Effects and cadmium on the biota: influence on environmental factors. Advances in Applied Microbiology, v. 23, p.55$117,1978$.

BAGY, M. M. K.; EL-SHAROUNY, H. M. M.; EL-SHANAWANY, A. A. Effect of $\mathrm{pH}$ and organic matter on toxicity of heavy metals to growth of some fungi. Folia Microbiologica, v.36, n.4, p.367-374, 1991.

BLACKWEEL, K. J.; TOBIN, J. M. Cadmium accumulation and its effects on intracellular ion pools in a brewing strain of Saccharomyces cerevisiae. Journal of Industrial Microbiology \& Biotechnology, v.23, n.3, p.204-208, 1999.

BASSO, L. C.; AMORIN, H. V. Estudo comparativo de leveduras selecionadas do processo industrial. Relatório Anual de Pesquisas em Fermentação Alcoólica, v.15, n.1, p.57-106, 1995.

BASSO, L. C.; AMORIN, H. V. Habilidade fermentativa de leveduras isoladas do processo industrial. Relatório Anual de Pesquisas em Fermentação Alcoólica, v.16, n.1, p.52-76, 1996. 
BASSO, L. C.; OLIVEIRA, A. J.; ORELlI, V. F. D. M.; CAMPOS, A . D.; GALLO, C. R.; AMORIM, H. V. Dominance of wild yeast over industrial yeast strain evaluated by karyotiping technique. Yeast Newsletter, v.52, n.2, p.50, 1993.

BELDE, P. M. J.; KESSELS, B. G. F.; MOELANS, I. M.; BORST-PAUWELS, G. W. F. H. Cd $\mathrm{Cd}^{+2}$ uptake, $\mathrm{Cd}^{+2}$ binding and loss of cell $\mathrm{K}^{+}$by a Cd-sensitive and a Cd-resistant strain of Saccharomyces cerevisiae. FEMS Microbiology Letters, v.49, n.3, p.493-498, 1988.

BORST-PAUWELS, G. W. F. H. Simulation of all-or-none K+ efflux from yeast provoked by xenobiotics. Biochimica et Biophysica Acta, v.937, n. 1, p.88-92, 1988.

BRADY, D.; DUNCAN, J. R. Bioacumulation of metal cations by Saccharomyces cerevisiae. Applied Microbiology and Biotechnology, v.41, n.1, p.149-159, 1994.

BRIN, M. Tranketalose: clinical aspects. Methods in Enzimology, v.9, p.506-514, 1966.

BROCK, T. D.; MADIGAN, M. T.; MARTINKO, J. M.; PARKER, J. Biology of microorganisms. 7. ed. Englewood Cliffs: Prentice Hall, 1994. 910 p. 
CROWE, J.H.; PANEK, A.D.; CROWE, L.M.; PANEK, A.C.; ARAÚJO, P.S. Trehalose transport in yeast cell. Biochemistry International, v.24, n.4, p.721-730, 1991.

DOMINGOS, R. N. Acúmulo de cádmio por Saccharomyces cerevisiae fermentando em mosto de melaço. Piracicaba, 1996. 63p. Dissertação (Mestrado) - Escola Superior de Agricultura "Luiz de Queiroz", Universidade de São Paulo.

ECKER, D. J.; BUTT, T. R.; STERNBERG, E. J.; NEEPER, M. P.; DEBOUCK, C.; GORMAN, J.; CROOKE, S. T. Yeast metallothionein function in metal ion detoxification. The Journal of Biological Chemistry, v.261, n.36, p.16.89416.900, 1986.

ELPO, E. R. S.; FREITAS, R. J. S. Avaliação de teores de cádmio, chumbo, cromo e níquel nos alimentos da cesta básica. Boletim do Centro de Pesquisa e Processamento de Alimentos, v.13, n.2, p.71-84, 1995.

ENDO, T.; SHAIKH, Z. Cadmium uptake by primary cultures of rat renal cortical epithelial cells: influence of cell density and other metal ions. Toxicological Applied Pharmacology, v.121, p.203-209, 1993.

FERGUSON, J. E. Heavy elements: chemistry, environmental impact an healthy effects. New-York: Pergamon Press, 614p. 1990. 
FUHRMANN, G.F.; ROTHSTEIN, A. The mechanism of a partial inhibition of fermentation in yeast by nickel ions. Biochimica et Biophisica Acta, v.163, p.331-338, 1968.

GADD, G. M. The uptake of heavy metals by fungi and yeasts: the chemistry and physiology of the process and applications for biotechnology. In: ECCLES, H; HUNT, S. Immobilization of heavy metals ions: immobilization of ions by bio-sorption. London: Ellis Horwood, 1986. cap.4, p.135-148.

GADD, G. M.: MOWLL, J. L. The relationship between cadmium uptake, potassium release and viability in Saccharomyces cerevisiae. FEMS Microbiology Letters, v.16, n.1, p.45 48, 1983.

GERHARDSSON, L.; SKERFVING, S. Concepts on biological markers and biomonitoring for metal toxicity. In: CHANG, L. W. Toxicology of metals. Boca Raton : CRC Press,. 1996. cap.6, p.81-112.

GLÓRIA, N. A.; ORLANDO-FILHO, J. Aplicação da vinhaça como fertilizante. Boletim Técnico Planalsucaar, v.5, n.1, p.1-38, 1983.

GOUVEAA, L. C. Estudo da compostabilidade do lodo de esgoto e avaliação da distribuição química de metais pesados no decorrer do processo. Viçosa, 1995, 255p. Dissertação (Mestrado) - Universidade Federal de Viçosa. 
GRAFL, H. J.; SCHWANTES, H. O. Der einfluss von cadmium, zink, blei und quecksilber auf das wachstum und das akkumulationsvermögen von Saccharomyces cerevisiae, Saccharomyces lipolytica, Candida tropicalis und Candida utilis. Zentralblatt fur Bakteriologie und Hygiene - serie B Umweithygiene Krankenhaushygiene Arbeitshygiene Praventive Medizin, v.177, n.1/2, p.57-74, 1983a.

GRAFL, H. J.; SCHWANTES, H. O. Der einfluss von cadmium, zink, blei und quecksilber auf die atmung und gärung von Saccharomyces cerevisiae. Angewandte Botanik, v.57, n.1/2, p.31-43, 1983 b.

GRAFL, H. J.; SCHWANTES, H. O. Einfluss von scwermetallinterakitionen auf das wachstum von Saccharomyces cerevisiae. Zentralblatt fur Bakteriologie und Hygiene - serie B - Umweithygiene Krankenhaushygiene Arbeitshygiene Praventive Medizin, v.177, n.6, p.514-526, 1983c.

GRIFFIN, D. H. Fungal physiology. 2. ed. New York: John Wiley, 1994. 458p.

GUTIERREZ, L. E. Tópicos de bioquímica de leveduras. Piracicaba: ESALQ, Núcleo de Apoio à Pesquisa em Microbiologia Agrícola, 1994. 103p..

GUTIERREZ, L. E.; ANNICCHINO, A. V. K. O.; LUCATTI, L.; STIPP, J. M. S. Efeito do níquel sobre Saccharomyces cerevisiae durante a fermentação alcoólica. Acta Biológica Leopodinensia, v.13, n.2, p.61-74, 1991. 
JORGE, J. A.; CAMARGO, O. A.; VALADARES, J. S. M. A. Condições físicas de um latossolo vermelho-escuro quatro anos após a aplicação de lodo de esgoto e calcáreo. Revista Brasileira de Ciência do Solo, v.15, n.3, p.237$240,1991$.

KARAMUSHKA, V. I.; SAYER, J. A.; GADD, G. M. Inhibition of H+ efflux form Saccharomyces cerevisiae by insoluble metal phosphates and protection by calcium and magnesium: inhibitory effects a result of metal cations? Mycological Research, v.100, n.6, p.707-713, 1996.

KESSELS, B. G. F.; BELDE, P. J. M.; BORST-PAUWELS, J. W. V. H. Protection of Saccharomyces cerevisiae against $\mathrm{Cd}^{2+}$ toxicity by $\mathrm{Ca}^{2+}$. The Journal of General Microbiology, v.131, n.10, p.2.533-2.537, 1985.

KITAJIMA, E. W. Curso introdutório de microscopia eletrônica de varredura. Piracicaba: ESALQ, Núcleo de Apoio à Pesquisa em Microscopia Eletrônica Aplicada à Pesquisa Agropecuária, 1997. 37p.

LIMA, G. J. M. M. Uso da levedura seca (Saccharomyces cerevisiae) de destilarias de álcool de cana-de-açúcar na alimentação de matrizes suínas em gestação e lactação. Piracicaba, 1983. 139p. Dissertação (Mestrado) - Escola Superior de Agricultura "Luiz de Queiroz", Universidade de São Paulo.

LOPES, J. J. C. Bagaço de nutrientes minerais no processo Melle-Boinot de fermentação alcoólica. Piracicaba, 1989. 74p. Dissertação (Mestrado) Escola Superior de Agricultura "Luiz de Queiroz", Universidade de São Paulo. 
MACASKIE, L. E.; DEAN, A C. R. Metal-sequesterning biochemicals. In: VOLESKY, B. Biosorption of heavy metals. Boca Raton: CRC Press, 1990. cap.2.5, p.199-248.

MARIANO-DA-SILVA, S.; PRADO-FILHO, L. G. Acúmulo de Cádmio por Saccharomyces cerevisiae em caldo de cana-de-açúcar contaminado com acetato de cádmio. Scientia Agricola, v.56, n.2, p.427-431, 1999.

MASON, J. O. Toxicological profiles: cadmium. Washington: Agency for Toxic Substances and Disease Registry, 1987. 100p.

McDANIEL, W. Sample preparation procedure for spectrochemical determination of total recoverable elements in biological tissues. In: SMOLEY, C. K. Methods for the determination of metals in environmental samples. Boca Raton: CRC Press., 1992. cap. 3, p.25-32.

MIDIO, A. F.; MARTINS, D. I. Toxicologia de alimentos. São Paulo: Editora Varela, 2000. 296p.

MYRBÄCK, K. Inhibition of yeast invertase (saccharase) by metal ions: II. Action of $\mathrm{Ag}^{+}, \mathrm{Cu}^{++}, \mathrm{Cd}^{++}, \mathrm{Zn}^{++}$ions and their complex formation with acetate ions. Arkiv för Kemi, v.8, n.40, p.393-400, 1955.

NAKAMURA, $H$. Adaptation of yeast to cadmium VII. Significance of polyphosphate in cadmium resistance. Botanical Magazine, v.78, p.85-90, 1965. 
NOGAWA, K.; KIDO, T. Itai-itai disease and health effects of cadmium. In CHANG, L. W. Toxicology of metals. Boca Raton: CRC Press. 1996. cap.21, p.353-369.

NORRIS, P. R.; KELLY, D. P. Accumulation of cadmium and cobalt by Saccharomyces cerevisiae. Journal of General Microbiology, v.99, n.2, p.317-324, 1977.

ORLANDO-FILHO, J.; SOUSA, I. C.; ZAMBELLO-JÚNIOR, E. Aplicação de vinhaça em soqueira de cana-de-açúcar. Boletim Técnico Planalsucar, v.2, n.5, p.1-34, 1980 .

PACYNA, J. M. Monitoring and assessment of metal contaminants in the air. In: CHANG, L. W. Toxicology of metals. Boca Raton: CRC Press., 1996. cap.1, p.9-28.

PARROU, J. L.; FRANCOIS, J. A. Simplified procedure for a rapid and reliable assay of both glycogen and trehalose in whole yeast cells. Analytical Biochemistry, v.248, n.1, p.186-188, 1997.

PAULING, L. The nature of the chemical bound and the structure of molecules and crystals. 3. ed. New York: Cornell University Press, 1961. $644 \mathrm{p}$.

PONS, M. N.; CHANEL, S. Effect of heavy metals on volatiles production in alcoholic fermentation by Saccharomyces cerevisiae. Journal of Fermentation and Bioengineering, v.72, n.1, p.61-63, 1991. 
PRADO-FILHO, 1. G.; DOMINGOS, R. N.; SILVA, S. M. G. Acúmulo de cádmio por Saccharomyces cerevisiae fermentando em mosto de melaço. Scientia Agrícola, v.55, n.1, p.128-132, 1998.

RAMAMOORTHY, S.; KUSHNER, D. J. Binding of mercury and other heavy metals ions by the microbial growth media. Microbial Ecology, v.2, p.162176, 1975.

REILLY, C. Mercury and cadmium. In: REILLY, C. Metal contamination of food. New York, Elsevier, 1991. cap.6, p.131-151.

REMACLE, J. The cell wall and the metal binding. In. VOLESK B. Biosorption of heavy metals, . Boca Raton, CRC Press, 1990. cap.2.1, p.82-92.

ROBARDS, K.; WOURSFOLD, P. Cadmium: Toxicology and analysis. Analyst, v. 116, n.6, p. 549-568, 1991.

RÖSICK, E.; MANGIR, M.; LOCHMANN, E. R. Unterschiedlich aufnahme von cadmium in Saccharomyces - BZW. Rhodotorula - zellen. Chemosphere, v.15, n.8, p.981-983, 1986.

RYGOL, J.; ARNOLD, W. M.; ZIMMERMANN, U. Zinc and salitit effects on membrane transport in Chara connivens. Plant Cell Environment, v.15, n.1, p.11-23, 1992. 
SAlGADO, P. E. T. Toxicologia dos Metais In: OGA, S. Fundamentos de toxicologia. São Paulo: Atheneu Editora, 1996a. cap.3.2., p.153-172.

SAlGADO, P. E. T. Metais em alimentos. In: OGA, S. Fundamentos de toxicologia. São Paulo: Atheneu Editora, 1996b. cap.5.2., p.441-460.

SANTOS, H. F.; TSUTIYA, M. T. Aproveitamento e disposição final do lodo de estações de tratamento de esgotos. São Paulo: SABESP, 1996. 25p.

SCHNETTLER, R., ZIMMERMANN, U. Zinc ions stimulate electrofusion of Hansenula polymorpha protoplasts. FEMS Microbiology Letters, v.106, n.1, p.47-52, 1993.

SILVA. D. J. Análise de alimentos: métodos químicos e biológicos. Viçosa: Universidade Federal de Viçosa, 1990. cap. 5, p.24-38: Dosagem de nitrogênio pelo método Kjeldahl.

SILVA, F. C. Uso agronômico do lodo de esgoto: efeitos em fertilidade do solo e qualidade da cana-de-açúcar. Piracicaba, 1995. 165p. Tese (Doutorado) Escola Superior de Agricultura “Luiz de Queiroz", Universidade de São Paulo.

SILVA, G. M.; ORLANDO-FILHO, J. Caracterização da composição química dos diferentes tipos de vinhaça do Brasil. Boletim Técnico Planalsucar, v.3, n.8, p.1-22, 1981. 
SILVA, S. M. G. Acúmulo de cádmio por Saccharomyces cerevisiae fermentando mosto de caldo de cana. Piracicaba, 1998. 52 p. Dissertação (Mestrado) Escola Superior de Agricultura “Luiz de Queiroz”, Universidade de São Paulo.

SMITH, C. A.; WOOD, E. J. Cell biology. 2. ed., Hong Kong: Chapman \& Hall, 1996. $540 \mathrm{p}$.

SNEDECOR, G. W.; COCHRAN, W. G. Statistical methods. 6. ed. Ames: The Iowa State University Press, 1967. 593p.

STEVENINCK, J. V. The influence of nickelous ions on carbohydrate transport in yeast cells. Biochimica et Biophysica Acta, v.126, n.1, p. 154-162, 1966.

STEVENINCK, J. V.; BOOIJ, H. L. The role of polyphosphates in the transport mechanism of glucose in yeast cells. Journal of General Physiology, v.48, n.1, p.43-60, 1964.

THEUVENET, A. P. R.; KESSELS, B. G. F.; BLANKENSTEIJN, W. M.; BORST-PAUWELS, G. W. F. H. Comparative study of $\mathrm{K}^{+}$loss from a cadmium-sensitive and a cadmium-resistant strain of Saccharomyces cerevisiae. FEMS Microbiology Letters, v.43, n.2, p. 147-153, 1987.

TIJSSEN, J. P. F.; BEEKES, H. W.; STEVENINCK, J. Localization of polyphosphates at the outside of the yeast cell plasma membrane. Biochimica et Biophsica Acta, v.649, p.529-532, 1981. 
TREVELYAN, W. E.; HARRISON, J. S. Studies on yeast metabolism 5. The trehalose content of baker's yeast during anaerobic fermentation. Biochemical Journal, v.62, p.177-183, 1956a.

TREVELYAN, W. E.; HARRISON, J. S. Studies on yeast metabolism 7. Yeast carbohydrate fraction. Separation from nucleic acid analysis and behavior during anaerobic fermentation. Biochemical Journal, v.63, p.23-33, 1956 b.

TREVORS, J.T.; STRATTON, G.W.; GADD, G.M. Cadmium transport, resistance and toxicity in bacteria, algae and fungi. Canadian Journal of Microbiology, v.32, n.6, p.447-464, 1986.

VALLE, B. L.; ULMER, D. D. Biochemical effects of mercury, cadmium and lead. Annual Review of Biochemistry, v.41, p.91-128, 1972.

VARMA, A. Group IIB elements ( $\mathrm{Zn}, \mathrm{Cd}, \mathrm{Hg})$. In: VARMA, A. Handbook of atomic absorption analysis. 3. ed. Boca Raton: CRC Press, 1986. v.2, cap.2, p.73-184.

VOLESKY, B. Removal and recovery of heavy metals by biosorption. In: VOLESKY, B. Biosorption of heavy metals. Boca Raton: CRC Press, 1990a. cap.1.2, p.7-43.

VOLESKY, B. Biosorption of fungal biomass. In; VOLESKY, B. Biosorption of heavy metals. Boca Raton: CRC Press, 1990b. cap.2.3, p.139-171. 
ZAGO, E. A.; AMORIM, H. V.; BASSO, L. C.; GUTIERREZ, L. E.; OLIVEIRA, A. J. Métodos analíticos para o controle da produção de álcool. Piracicaba: FERMENTEC;ESALQ-USP, 1989. 144p. 